The African-Jamaican Aesthetic 


\title{
Cross/Cultures
}

READINGS IN POST/COLONIAL

LITERATURES AND CULTURES IN ENGLISH

\author{
Edited by \\ Gordon Collier \\ Geoffrey Davis \\ Bénédicte Ledent
}

Co-founding editor

†Hena Maes-Jelinek

VOLUME 196

The titles published in this series are listed at brill.com/cc 


\section{The African-Jamaican Aesthetic}

Cultural Retention and Transformation Across Borders

By

Lisa Tomlinson

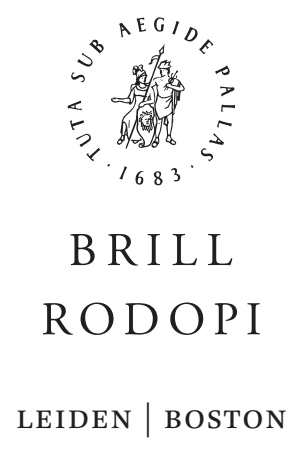


This is an open access title distributed under the terms of the CC BY-NC-ND 4.0 license, which permits any non-commercial use, distribution, and reproduction in any medium, provided no alterations are made and the original author(s) and source are credited. Further information and the complete license text can be found at https://creativecommons.org/licenses/by-nc-nd/4.0/

The terms of the CC license apply only to the original material. The use of material from other sources (indicated by a reference) such as diagrams, illustrations, photos and text samples may require further permission from the respective copyright holder.

An electronic version of this book is freely available, thanks to the support of libraries working with Knowledge Unlatched. More information about the initiative can be found at www. knowledgeunlatched.org.

Cover illustration: (c) Gratanio L. Thomas, True Gathering (3 March 2015; pencil and crayon on acid-free paper, $26 \mathrm{~cm} \times 35.5 \mathrm{~cm})$.

Library of Congress Control Number: 2016962409

Typeface for the Latin, Greek, and Cyrillic scripts: "Brill”. See and download: brill.com/brill-typeface.

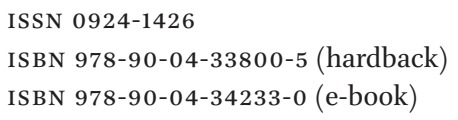

Copyright 2017 by Lisa Tomlinson. Published by Koninklijke Brill NV, Leiden, The Netherlands. Koninklijke Brill NV incorporates the imprints Brill, Brill Hes \& De Graaf, Brill Nijhoff, Brill Rodopi, Brill Sense, Hotei Publishing, mentis Verlag, Verlag Ferdinand Schöningh and Wilhelm Fink Verlag. Koninklijke Brill NV reserves the right to protect this publication against unauthorized use.

This book is printed on acid-free paper and produced in a sustainable manner. 


\title{
— Table of Contents -
}

\author{
Introduction \\ vii \\ 1
}

Work Songs, Proverbs, and Storytelling in Jamaican Literary Tradition

1

2

The African-Jamaican Aesthetic, Pan-Africanism, and Decolonization in Early Jamaican Literature

29

3

Crossing Over to the Diaspora:

The Reggae Aesthetic, Dub, and the Literary Diaspora

69

4

Gendering Dub Culture Across Diaspora:

Jamaican Female Dub Poets in Canada and England

105

5

Home Away from Home:

The African-Jamaican Aesthetic in Diasporic Novels

137

Conclusion

163

Works Cited

183

Index

201 



\section{- Introduction -}

$\mathrm{T}$

HIS STUDY EXAMINES the African-Jamaican aesthetic impulse in diasporic dub poetry and fiction paying particular attention to how these art forms have developed and been mediated in Canadian and British contexts. More specifically, I explore how African-Jamaican cultural productions of the diaspora are employed as a means of recovering, rearticulating, and remaking cultural identities that have been disrupted by histories of slavery and colonial conquest. My research demonstrates how the cultivation of an African-Jamaican aesthetic plays a key role in inspiring community activism, creating cultural spaces, and forging and sustaining cultural identities in Caribbean diasporas. In making these claims, I borrow from VèVè Clark's notion of "diaspora literacy," which offers a way to approach the literatures of the African diaspora from "an informed indigenous perspective," and Farah Shroff's definition of indigenous knowledge as a legitimate system of knowledges that has been discredited within the authority of Western discourse. ${ }^{2}$ These definitions enable a focus on the creative continuity of indigenous knowledges and local cultures in African-Jamaican diasporic literary production.

According to George Dei, indigenous knowledges provide an anti-colonial framework and constitute a kind of "knowledge consciousness that arises from

${ }^{1}$ VèVè A. Clark, "Developing Diaspora Literacy and Marasa Consciousness," Theatre Survey 50.1 (May 2009): 11 .

${ }^{2}$ Farah M. Shroff, "Ayurveda: Mother of Indigenous Health Knowledge," in Indigenous Knowledges in Global Contexts: Multiple Readings of Our World, ed. George J. Sefa Dei, Budd L. Hall \& Dorothy Goldin Rosenberg (Toronto: U of Toronto P, 2000): 228. 
the colonized presence."3 Indigenous knowledges are also associated with the "everyday ideas and cultural knowledges of local peoples concerning the realities of living." In this context, the multiple ways of knowing function in an alternative space that equates communal folk knowledge with other credited forms of knowledge. Within an African-Jamaican diasporic framework, these knowledges may include nation language $\left(\mathrm{Patwa}^{5}\right)$, religion, music, dance, folk culture, and ritual, all of which inform African-Jamaican diasporic writing. The present study focuses on the function of nation language, religion, music and dance, and folk culture in the work of the Canadian dub poets Afua Cooper, Lillian Allen, and Adhri Zhina Mandiela; the UK dub poets Jean 'Binta' Breeze, Linton Kwesi Johnson (LKJ), and Benjamin Zephaniah; and the diasporic novelists Makeda Silvera and Joan Riley. The works of these poets and novelists provide rich material for exploring a diverse cross-section of African-Jamaican aesthetic applications.

While African-Jamaican culture boasts a rich array of artistic production, I have chosen to discuss dub poetry and fiction because, like popular music, literature has played a critical role in motivating community activism and articulating African-Jamaican experiences in the diaspora. These articulations include reflections on dislocation, racialization, belonging, and citizenship in diasporic contexts. It is important to note that, rather than exploring these reflections through either a fixed notion of identity or theories of "postmodernist hyper-hybridity," this study offers an intervention in diasporic studies by arguing that close examination of African-Jamaican cultural productions reveals

${ }^{3}$ George J. Sefa Dei, "African Development: The Relevance and Implications of 'Indigenousness', " in Indigenous Knowledges in Global Contexts: Multiple Readings of Our World, ed. George J. Sefa Dei, Budd L. Hall \& Dorothy Goldin Rosenberg (Toronto: U of Toronto P, 2000): 72.

${ }^{4}$ George J. Sefa Dei, "Spiritual Knowing and Transformative Learning," in Expanding the Boundaries of Transformative Learning: Essays on Theory and Praxis, ed. E.V. O'Sullivan, A. Morrell \& M.A. O'Connor (New York: Palgrave, 2002): 124.

${ }^{5}$ I use the spelling 'Patwa' interchangeably with the linguistic term 'creole' as opposed to the French usage of patois as a way not only to give legitimacy to the Jamaican local language but also to take away the pejorative and hierarchical connotation of the French spelling.

${ }^{6}$ Postmodernist hyper-hybridity is a phrase I borrow from Chambers' essay "The Black Atlantic: Theory, Method, and Practice," which he uses to describe an over-emphasis on hybridity, which often results in a failure to acknowledge the specific ways in which blackness is performed and experienced in the African diaspora, both culturally and socio-historically. 
both a persistent continuity of African aesthetics and a dialogue with local and diasporic realities. Even as Africa-derived cultural productions in Jamaica have been disrupted by histories of fragmentation and loss, and even while, out of necessity, they have interacted with the diverse cultural landscapes of the Caribbean and its diasporas, this work argues that they also continue a conversation with the memory of Africa, whether metaphoric or 'real'. Indeed, although these memories might be entirely re-created and re-imagined, for many diasporic African peoples they represent the only connection they have to a severed historical past and in this sense constitute a certain kind of reality. Such a revelation also suggests that while African-Jamaican identities may be anchored in African and Caribbean cultural traditions, they have also been fluid enough to respond to diverse local conditions and to open up dialogue across diasporic borders and the multiple formations of 'home'.

It is important to note that this research employs an anti-colonial discourse in its approach to theorizing cultural development. I am interested in unpacking the discursive agency in African-Jamaican cultural expression, particularly in terms of how they reflect the strength of local knowledges and social practices in aiding the survival of colonized peoples. ${ }^{7}$ In addition, the work draws on diasporic studies, black feminist thought, and pan-Africanism in its analysis of the meaning and social impact of African-Jamaican literary productions. These theories underpin my examination of how the African-Jamaican dub poetry and fiction selected serve as a means by which dominant discourses of 'race' and identity might be challenged, troubled, or possibly reinforced.

Finally, this study considers the role African-Jamaican cultural traditions play in the production of national identities in new diasporic contexts. I also look at how forms of black Jamaican cultural aesthetics are adapted by firstand second-generation Canadian and British Jamaicans. An African-Jamaican aesthetic, I suggest, continues to provide an important cultural 'grounding', which has allowed Jamaicans living abroad to identify and enter into dialogue with other African diasporic peoples in order to articulate new narratives about national belonging in differing geographic spaces.

\footnotetext{
${ }^{7}$ George J. Sefa Dei \& Alireza Asgharzadeh, "The Power of Social Theory: Towards an Anti Colonial Discursive Framework," Journal of Educational Thought 35.3 (2001): 297.
} 


\section{Anti-Colonialism in the Diaspora and the Decolonization of Jamaica's Literary Traditions}

Without ignoring the tremendous contributions of the Taino, Arawak, and Kalinago and their struggle against extinction at the hands of European colonizers, this work argues that the long historical presence of people of African descent in the Caribbean, marked as it was by deliberate attempts to sever their connections with the past and by the impossibility of a physical return, has resulted in a genuine and sustained confrontation with and transformation of the social and cultural environment. This dual confrontation and transformation have given rise to centuries of accumulated memories that also situate peoples of African descent as indigenous to this region.

As I make this claim, I am cautioned by Melanie Newton about a tendency in Caribbean scholarship to inscribe "narratives of aboriginal absence." ${ }^{8}$ As she argues, anglophone Caribbean studies have largely relied on the assumption 'that new 'natives,' predominantly Africans and their descendants replaced the original Antilleans and became indigenous to the Caribbean." ${ }^{\prime 9}$ My work, however, does not seek to replace one set of indigenous experiences or knowledges with another, but to recognize the complex interconnections that have shaped Caribbean experiences. The Amerindian, African, European, Indian, and Chinese presences in the Caribbean, as Stuart Hall maintains, have long been entangled with each other:

The New World is the third term - the primal scene - where the fateful / fatal encounter was staged between Africa and the West. It also has to be understood as the place of many, continuous displacements: of the original preColumbian inhabitants, the Arawaks, Caribs and Amerindians, permanently displaced from their homelands and decimated; of other peoples displaced in different ways from Africa, Asia and Europe; the displacements of slavery, colonization and conquest. ${ }^{10}$

\footnotetext{
${ }^{8}$ Melanie Newton, "Returns to a Native Land: Indigenity and Decolonization in the Anglophone Caribbean," Small Axe 17.2 (July 2013): 109.

${ }^{9}$ Newton, "Returns to a Native Land," 109.

${ }^{10}$ Stuart Hall, "Cultural Identity and Diaspora," in Identity: Community, Culture, Difference, ed. Jonathan Rutherford (London: Lawrence \& Wishart, 1990): 234.
} 
In this sense, we can think of the Caribbean as constituting intersecting historical memories and intersecting indigeneities. Mark Campbell proposes, as I do in this study, that an African-Jamaican presence has existed in Jamaica long enough to be conceived of in indigenous terms. ${ }^{11}$ Campbell argues in addition:

definitions of what constitute indigenous knowledge have often overlooked how transnational slavery has positioned some diasporic Blacks closer to being an indigenous population than a foreign population. ${ }^{12}$

Orlando Fals Borda agrees with Campbell, positing that 'indigeneity' refers "to knowledge resulting from long term residence in a place. ${ }^{\prime 13}$ George Dei's definition of indigenous knowledge can also be applied to the African-Jamaican experience, noting as he does that "these knowledges are part of the cultural heritage and histories of people."14 The present survey recognizes this understanding of the experiences of people of African descent in the Caribbean as constituting a valuable set of indigenous knowledges.

In the exploration of this understanding of (shared) indigeneity, a cornerstone of the present study is the use of an 'insider' perspective to document agency and identity-formation in African-Jamaican diasporic communities. While an 'insider' perspective can be problematic when it represents narrow nationalist interests, ${ }^{15}$ my work insists that indigeneity exists in the shared experiences of a people even in diaspora. This study, therefore, challenges the notion that some voices and cultural locations have exclusive access and privilege within national discourses. Arguments like these ignore the ways in which cultures cross borders and the ways in which cultural flows intersect. The 'insider' perspective I employ expands on Dei's notion of indigenous knowledge. He rightly notes that this indigenous knowledge is "an important entry point"

${ }^{11}$ Mark Campbell, "Indigenous Knowledge in Jamaica: A Tool of Ideology in a Neo-Colonial Context," in Anti-Colonialism and Education: The Politics of Resistance, ed. George J. Sefa Dei \& Arlo Kempf, foreword by Molefi Kete Asante (Rotterdam: Sense, 2006): 193.

${ }^{12}$ Campbell, "Indigenous Knowledge in Jamaica," 195.

13 Orlando Fals Borda, "Science and the Common People," Journal of Social Studies 11 (1981): 19.

${ }^{14}$ George Dei, Rethinking the Role of Indigenous Knowledges in the Academy (N ALL Working Paper 58, 2002): 4-5.

${ }^{15}$ Andrea Davis, "Translating Narratives of Masculinity Across Borders: A Jamaican Case Study," Caribbean Quarterly 52.2-3 (June-September 2006): 25. 
for anti-colonial research. ${ }^{16}$ While drawing on Dei's anti-colonial framework, I take the further step of suggesting that diasporic African-Jamaicans call on the indigenous knowledge systems they bring with them to construct their own vocabulary and to shape their cultural responses in cities like Toronto and London. In doing so, I expand on Dei's notion of indigeneity to include the way colonized peoples rework cultural aesthetics and knowledges in the specificity of their changing environments.

To be sure, the strength of an anti-colonial framework is that it allows one to draw on many different discursive traditions and to integrate indigenous knowledges in explorations and explanations of the socio-economic, political, and cultural phenomena affecting African diasporic peoples. As such, an anticolonial discourse offers a language and prism through which to understand African-Jamaican cultural productions in a way that places African-Jamaican artists and their communities as active agents in their everyday experiences and struggles. In addition, while anti-colonialism may borrow from other theoretical frameworks, it is not constrained in any way by dominant epistemologies. As Dei and Kempf observe, anti-colonial research represents the "emergence of a new political, cultural and intellectual movement reflecting the values and aspirations of colonized and resisting peoples/subjects. ${ }^{\text {"17 }}$

Diaspora studies are also clearly relevant to my research, offering as it does a framework for conceptualizing and understanding the experiences of AfricanJamaican people in Canada, the UK, and other diasporic spaces. Diasporic concepts such as the scattering of families and communities, forced displacement, shared histories of slavery, colonization, and neocolonialism, racialization, minority status, and lost identities are all helpful markers in mapping how peoples of African descent, especially those from the Caribbean, contest dominant socio-cultural meanings, reconstruct identity, and validate erased and distorted histories in their new diasporic homelands.

In particular, I find VèVè Clark's notion of "diaspora literacy," which she defines as the ability to "read and comprehend the discourses of Africa, AfroAmerica and the Caribbean from an informed, indigenous perspective,"18

${ }^{16}$ Dei, Rethinking the Role of Indigenous Knowledges in the Academy, 7.

${ }^{17}$ George J. Sefa Dei \& Arlo Kempf, "Introduction" to Anti-Colonialism and Education: The Politics of Resistance, ed. Dei \& Kempf (Rotterdam: Sense, 2006): 4.

${ }^{18}$ Clark, "Developing Diaspora Literacy and Marasa Consciousness," 11. 
especially helpful in considering the use of folk cultures in my selection of literary works. As Clark explains further,

This type of literacy is more than a purely intellectual exercise. It is a skill for both narrator and reader which demands a knowledge of historical, social, cultural and political development generated by lived and textual experience. ${ }^{19}$

Like Dei's indigenous knowledge systems, Clark's notion of diaspora literacy provides an anti-colonial reading that challenges the "monochrome logic of Western epistemology." ${ }^{\text {"2o }}$ Clark's work is particularly useful because it allows us to think about how indigenous knowledges function in the diaspora. As Clark argues, "the consciousness accompanying the revision in which many of us participate has no name.".1 It is this revision - "the reformation of form" ${ }^{\text {"22 }}$ - that is indispensable to the formation of a critical language that can frame the activism of the Caribbean diaspora in countries like Canada and Britain.

Scholarly work produced on the black diaspora that privileges eurocentric discourse negates global and collective narratives and over-simplifies understandings of people of African descent. ${ }^{23}$ Such scholarship contributes to a perception of black people as the 'Other', thereby further silencing the subaltern and effectively shrinking the academic space available for multiple and diverse voices. In contrast, readings of the black diaspora that opens up a space for African-centred interrogations can result in deeper insights into Afro-Caribbean diasporic experiences. Kwame Dawes' book Natural Mysticism, for example, uses reggae music to foreground the cultural, political, and social development of Jamaican society. In this vein, my approach seeks to use inclusive theoretical frameworks that allow me to uncover personal and collective narratives and to articulate how these both reflect and influence the lived experiences of African-Jamaican people. Indeed, my intention is not to engage with

19 "Developing Diaspora Literacy and Marasa Consciousness," 11.

${ }^{20}$ Tony Moodie, "Re-Evaluating the idea of Indigenous Knowledge: Implications of Anti-Dualism in African Philosophy and Theology," paper presented at "African Renewal, African Renaissance': New Perspectives on Africa's Past and Africa's Present (African Studies Association of Australia and the Pacific Annual Conference 26-28 November 2004): 12.

${ }^{21}$ Moodie, "Developing Diaspora Literacy and Marasa Consciousness," 11.

22 "Developing Diaspora Literacy and Marasa Consciousness," 11.

${ }^{23}$ Dei, Rethinking the Role of Indigenous Knowledges in the Academy, 10. 
diaspora studies as an exercise in theoretical abstractions but, rather, as a means of understanding the performance of the everyday (as represented in African-Jamaican aesthetics) in the lives of people of African descent.

Jana Braziel and Anita Mannur draw attention to the shortcomings of postmodernism when exploring diasporic themes:

theorizations of diaspora need not, and should not, be divorced from historical and cultural specificity [... but should] emerge from this base of scholarship rather than postmodern theoretical abstractions of displacement and movement. $^{24}$

It is important to note, however, that while diaspora studies provide a better framework for my work than postmodernism, some challenges remain. For instance, I find that Stuart Hall extends some of his discourse on the ruptures and discontinuities in African diasporic cultural formation too far, ${ }^{25}$ in particular his decision to figure Africa "only [as] an imagined presence of AfroCaribbean peoples." ${ }^{26}$ Indeed, Hall runs the risk of treating Africa as a mere ghostly shadow on African diasporic cultural identities. In contrast, I am interested in uncovering cultural continuities that flow from Africa and throughout its diaspora despite harsh histories of slavery, colonization, and migration. In doing so, I aim to acknowledge both continuities and discontinuities.

Other diasporic theorists exhibit different limitations. For example, while Floya Anthias offers a useful critique of Gilroy's and Hall's exclusion of gender and their emphasis on "differentiated ethnicity," ${ }^{27}$ she herself fails to adequately capture the intersections of race and gender in black people's lives; thus, her work is limiting when considering Afro-Caribbean women. Michel Wieviorka proposes that our understanding of racism should be extended beyond current configurations of white versus black to a form he calls "differential/cultural racism. ${ }^{28}$ He goes on to use the experiences of Jewish Americans to delineate

\footnotetext{
${ }^{24}$ Jana E. Braziel \& Anita Mannur, "Nation, Migration, Globalization: Points of Contention in Diaspora Studies," in Theorizing Diaspora, ed. Jana E. Braziel \& Anita Mannur (Malden MA: Blackwell, 2003): 3 .

${ }_{25}$ Stuart Hall, "Cultural Identity and Diaspora," 226-227.

${ }^{26}$ Charles Piot, "Atlantic Aporias: African and Gilroy's Black Atlantic," South Atlantic Quarterly 100.1 (Winter 2010): 156 .

${ }^{27}$ Floya Anthias, “Evaluating ‘Diaspora': Beyond Ethnicity?” Sociology 32.3 (August 1998): 571.

${ }^{28}$ Michel Wieviorka, "Racism and Diasporas," Thesis Eleven 52.1 (1998): 71.
} 
the problem of racism in the USA; unfortunately, this approach depoliticizes racism in a North American context by silencing questions of race and class, even while reinserting troubling racial hierarchies. As such, Wieviorka's article limits our ability to fully contextualize the Afro-Caribbean diaspora. His discussion also lacks any analysis of gender and/or gendered racism.

Clearly, these limitations in diasporic studies are problematic. For my own part, as a scholar of African descent living in Canada, I find race, gender, class, and immigrant status, and the ways they intersect, to be pivotal to my examination of African diasporic experiences. Tony Martin suggests that the diaspora as a concept has itself become a dominant ideology, and he takes a subversive stance by eliminating the term entirely. Martin calls instead for the use of a new word that can accurately address the unique experiences of people of African descent. While I do not wish to depart wholly from the use of diaspora studies in my approach, I can appreciate Martin's desire to push against tendencies towards Euro-American hegemony in our adopted theoretical frameworks. $^{29}$

Neither diasporic theory nor anti-colonial theory alone is adequate to embarking on a study of the African-Jamaican aesthetic in the diaspora. I find the inclusion of black feminist theory vital because of its strengths in inserting and insisting on the lived narratives of black female subjectivity, which necessarily encompass categories of race, gender, and class. While literary movements such as the French Caribbean's Négritude, the Spanish Caribbean's Negrismo, and the Harlem Renaissance and the Black Aesthetic Movement in the USA served as pivotal strategies for a reinvigoration of black cultural aesthetics in the nineteenth century (as distinct from the customary white literary establishment), they were problematic in their over-reliance on black male voices. On the other hand, first- and second-wave feminisms were equally exclusive in their focus on the concerns of white, middle-class women and in their exclusion of racialized women in their imaginings of gender justice and definitions of womanhood and femininity. Using a black feminist discourse thus provides an important means of broadening the scope of examination when considering African-Jamaican diasporic experiences. The African-Jamaican female writers considered in this work use black diasporic aesthetic impulses to respond to

${ }^{29}$ Tony Martin, "Garvey and Scattered Africa," in Global Dimensions of the African Diaspora, ed. Joseph E. Harris (Washington DC: Howard U P, 1983): 243-49. 
the specificity of their social location in the diaspora. A black feminist discourse helps to focus on those specificities and re-centres the black female subject as essential to the struggle for cultural liberation from white hegemony.

Two black feminist theorists of note, Michelle Wright and Althea Prince, strengthen the discourse of diaspora studies by placing race, class, and gender at the centre of their work. In order to explicate the experiences of African Caribbean people living in Canada, Prince delves into her own lived experience as an Afro-Caribbean woman. This allows her to uncover everyday narratives in her diasporic inquiry. At the same time, while Prince acknowledges sexism in the works of C.L.R. James and other notable black scholars, she is able to reimagine and re-calibrate their concepts to explore her narratives of workingclass black Caribbean women. Though Wright's work is grounded more in theory, she, too, highlights the multiplicity and complexity of African diasporic communities. In taking up themes of gender, race, and class, her scholarship speaks to the diversity of histories, events, experiences, and ideas that have shaped the development of the African diaspora. Certainly the literary writers that are included in my analysis are also reflective of this kind of diversity.

Although I find a black feminist discourse invaluable, I am also cognizant that, given its origins in the USA, one must be cautious about its tendency to "Americocentrism" (a term I borrow from George Elliott Clarke ${ }^{30}$ ). Thus, when using elements of black feminism to contextualize the African diaspora, I am mindful of the importance of the specificity of local context, especially in relation to immigrant experiences. Nonetheless, as Roberta Timothy points out, anti-colonial or black feminist thought is invaluable, in that it "records, examines, strategizes and changes ideologies and structures, individually, collectively and transnationally," which enables diverse voices to be heard and hegemonic knowledges disrupted. ${ }^{31}$

Finally, in order to strengthen an understanding of the political and social dynamics underlying the development of African-Jamaican dub poetry and literature, I find it valuable to integrate pan-Africanism into my work. Indeed,

${ }^{30}$ George Elliott Clarke, "Must All Blackness Be American? Locating Canada in Borden's 'Tightrope Time,' or Nationalizing Gilroy's The Black Atlantic," Canadian Ethnic Studies 28.3 (1996): 5672.

${ }^{31}$ Roberta Timothy, "Resistance Education: African / Black Women Shelter Workers' Perspectives" (doctoral dissertation, University of Toronto, 2007): 81. 
many scholars have adopted pan-Africanism to help explain cultural links between the African continent and the black diaspora. Although pan-Africanism is often criticized for being essentialist, or idealist, or both, I believe it is worth taking into account. While pan-Africanism is not central to my own theoretical groundings, it is nevertheless useful when looking at both historical and contemporary forms of Jamaican literary expression. Many African Caribbean artists from the nineteenth century to the present have incorporated a panAfrican sensibility in their work. For these artists, pan-Africanism is both a mode of resistance to European ideologies and a form of outlaw culture ${ }^{32}-\mathrm{a}$ term bell hooks uses to denote insurgent culture - that allows them to explore and define their own cultural identity.

For some early theorists, such as Edward Wilmot Blyden and Marcus Garvey, pan-Africanism came to be defined as a call for African unity within, and between, the continent and the diaspora, while for others, like Frederick Douglass, it signalled the struggle for civil rights in their diasporic homelands. Nonetheless, as John Henrik Clarke contends, ultimately the aim of restoring of "respect" to persons of African descent remained the central impetus in all panAfricanist agendas. ${ }^{33}$ Black writers who inserted a pan-African sensibility into their literary work began creating a dialogue that was taken up in the Négritude and Harlem Renaissance movements and continued on through at least the end of the twentieth century. Prominent pan-African advocates, too, clearly saw the potential of art and literature as powerful political vehicles. Whether through prose, fiction, poetry or drama, black writers sought to validate an African presence that had been historically deemed culturally inferior and/or rendered invisible. At times they also returned their protagonist(s) to Africa through spiritual, metaphorical, or literal journeys of healing. Not surprisingly, then, incorporating pan-Africanism is important for my own research, as it helps me seee the critical value of literary art (folk culture) as an often simultaneously philosophical, cultural, and political undertaking.

\footnotetext{
${ }^{32}$ bell hooks, Outlaw Culture: Resisting Representations (New York: Routledge, 1994): 5 .

${ }^{33}$ John Henrik Clarke, "Pan Africamism: A Brief History of an Idea in the African World," The Third World First 1.2 (1990): 9-24.
} 
I find Christel Temple's work to be particularly useful. ${ }^{34}$ She employs a methodology in her literary scholarship that relies on unconventional perspectives such as literary pan-Africanism to uncover shared cultural links between black diasporic literatures in the Americas and continental African literatures. Temple insists on considering alternative, African-centred knowledges, especially vernacular traditions, in her analysis of black literary production, an attempt, in part, to move away from dominant Euro-Western literary discourses.

Overall, as I have demonstrated in this section, I find Dei's anti-colonial framework, VèVè Clark's diaspora literacy, and Temple's literary pan-African discourse all invaluable for unpacking and understanding black diasporic literatures. By expanding and interweaving these various theoretical positions, I hope to demonstrate the centrality of the African-Jamaican aesthetic to an anti-colonial struggle in Jamaica and its diaspora.

\section{Literature Review}

There is a significant body of academic scholarship examining the links between the literature of the Caribbean region and its diaspora. Some of this scholarship focuses on literary production through the lens of migration, ${ }^{35}$ while others consider questions of globalization and transnationalism..$^{36}$ Much is also concerned with issues of gender and sexuality. ${ }^{37}$ Work on this topic has

${ }^{34}$ Christel Temple, Literary Pan-Africanism: History, Contexts, and Criticism (Durham NC: Carolina Academic Press, 2005); Temple, "Rescuing the Literary in Black Studies," Journal of Black Studies 36.5 (May 2006): 764-85.

${ }_{35}$ Adlai Murdoch, Creolizing the Metropole: Migrant Caribbean Identities in Literature and Film (Bloomington: Indiana UP, 2012); Middle Passages and the Healing Place of History: Migration and Identity in Black Women's Literature, ed. Elizabeth Brown-Guillory (Columbus: Ohio State UP, 2006); Meredith M. Gadsby, Sucking Salt: Caribbean Women Writers, Migration and Survival (Columbia: $\mathrm{U}$ of Missouri P, 2006).

${ }^{36}$ Jopi Nyam, Home, Identity, and Mobility in Contemporary Diasporic Fiction (TexTxet 59; Amsterdam \& New York: Rodopi, 2009); Supriya Agarwal \& Jasbir Jain, Shifting Homelands, Travelling Identities (New Delhi: Sterling, 2008); Christine G.T. Ho \& Keith Nurse, Globalisation, Diaspora and Caribbean Popular Culture (Kingston, Jamaica: Ian Randle, 2005).

${ }^{37}$ Odile Ferly, A Poetics of Relation: Caribbean Women Writing at the Millennium (New York: Palgrave Macmillan, 2012); Middle Passages and the Healing Place of History, ed. Brown-Guillory; 
increasingly moved beyond simply documenting the interconnections between Caribbean writers and their diasporic counterparts to complicating and problematizing various facets of those connections.

Among the works that look specifically at the literary and cultural interconnections between the Caribbean and Canada and Britain are those of Bucknor, Davis, and Kebe. Michael Bucknor examines themes of retention and transformation in Caribbean Canadian literary works through the use of the metaphoric framework "body memory, ${ }^{138}$ which is partly responsible for the emergence of a uniquely Caribbean Canadian poetic:

the distinctive poetics of Caribbean / Canadian writing [is] concerned with the fluctuations and pulses of aesthetic and linguistic patterns; body memory poetics accentuates verbal rhythm rather than verbal reference. ${ }^{39}$

Andrea Davis scrutinizes the shared sensibility and understandings of black women reflected in African diasporic writing, ${ }^{40}$ underscoring the formal and thematic links that bind the fictional writings of Afro-Caribbean writers to writers elsewhere in the Americas. She argues that these links point to a shared literary poetic in a shared cultural hemisphere. In a similar vein, Amy Kebe examines continuities in the work of three African Caribbean Canadian writers - Dionne Brand, Marlene Nourbese Philip, and Makeda Silvera - who, despite their differing nations of birth, enact a transnational feminist identity that rejects simplistic notions of gender oppression while simultaneously challenging masculinist notions of home. Kebe also looks at how these writers inhabit the 'in-between' spaces between patriarchal imperialism and colonialism. ${ }^{41}$

Gadsby, Sucking Salt; Angeletta K.M. Gourdine, The Difference Place Makes: Gender, Sexuality, and Diaspora Identity (Columbus: Ohio State UP, 2002).

${ }^{38}$ Michael A. Bucknor, "Postcolonial Crosses: Body-Memory and Inter-Nationalism in Caribbean/Canadian Writing” (doctoral dissertation, University of Western Ontario, 1998).

${ }^{39}$ Bucknor, "Postcolonial Crosses," iii.

${ }^{40}$ Andrea Davis, "Hegemony of the Spirit: Black Women's Resistance and Healing through African Diasporic 'Counter Cultures of Modernity' in Selected African Caribbean and African American Women's Writing” (doctoral dissertation, York University, 2002).

${ }^{41}$ Amy Kebe, "Geographies of Displacement: Theorizing Feminism, Migration, and Transnational Feminist Practices in Selected Black Caribbean Writers" (doctoral dissertation, University of Montreal, 2009). 
The present study seeks to complement and extend the scholarship of Bucknor, Davis, and Kebe by looking specifically at African-Jamaican aesthetic approaches and how these are represented in the works of African-Jamaican writers residing in Toronto and London. While Bucknor's use of body memory is a valuable way of examining Caribbean Canadian literature, I rely chiefly on a textual analysis of Jamaican diasporic writings with a thematic emphasis. Such an approach allows me to consider how individual fiction writers and dub poets engage with vernacular language (i.e. Jamaican Patwa), folk culture, religious practices, racialization, migration, and working-class experiences in their artistic production. I believe that looking at dub poetry and novels through these lenses results in a deeper understanding of both African-Jamaican diasporic literatures and, more broadly, African-Jamaican experiences in Toronto and London. It is important to note that my aim here is not to provide sociohistorical readings of African-Jamaican literary works but, rather, to provide a detailed analysis, charting patterns of identity retention and transformation in the African-Jamaican cultural aesthetic in the diaspora.

While my research also thematizes gender, I take a somewhat different approach from Davis and Kebe, whose studies focus mainly on recurring notions of trauma, gender violence, and patriarchy. My goal is to uncover how AfricanJamaican women authors write from different geo-social locations from those of their male counterparts as they attempt to negotiate both racial and gender identity in new diasporic locations. In addition, I am interested in how these authors employ an African-Jamaican aesthetic strategy from a typically woman-centred, as well as indigenous, point of view by drawing on oral and folk cultural traditions.

Departing somewhat from the approaches already identified, Christian Habekost focuses solely on dub poetry in Jamaica, Toronto, and London. ${ }^{42}$ By studying multiple versions of dub poems, including printed, recorded, and live performance iterations, Habekost provides a working method for reading dub poetry within a sound and performance aesthetic and across geographic space. His work also contextualizes dub poetry by offering an overview of key practitioners, major dates, places, and events, and examining the art forms links to Jamaican popular music, dancehall DJs, Rastafarian religion, and Patwa (as a

\footnotetext{
${ }^{42}$ Christian Habekost, Verbal Riddim: The Politics and Aesthetics of African Caribbean Dub Poetry (Cross / Cultures 10; Amsterdam \& Atlanta G A: Rodopi, 1993).
} 
legitimate language for cultural and literary expression). While Habekost provides a useful overview of Caribbean dub culture in the Caribbean and its diaspora, his analysis privileges the performance of male poets. My work instead is a formal attempt to integrate an analysis of both dub poetry and fiction within analysis of race, gender, and sexuality, while thinking about the ways in which Jamaican cultural productions cross and mediate borders.

Existing literary scholarship that draws on the notion of diasporic literacy within the framework of indigenous knowledges includes the work of such scholars as Ingrid Reneau, ${ }^{43}$ who identifies dance (ringshout) as a tool of continuity in Toni Morrison's Beloved and Paule Marshall's Praisesong for the Widow. Reneau focuses on how these writers use dance as an important site of remembrance and ancestral bonding. Her research, like mine, is informed by ideas about the interconnectedness of peoples of African descent and the ways in which the 'New World' continues to engage in an interdependent relationship with continental Africa. ${ }^{44}$ In this way, both Reneau and I understand the potency of origin in a way that departs from a Black Atlantic epistemology. ${ }^{45}$ My work, however, extends beyond dance to consider multiple cultural and aesthetic influences on African-Jamaican literature. And while Reneau concentrates on fiction, I include dub poems as part of my exploration of transnational articulation.

Hugh Hodges' book Soon Come also has some similarities with my study, particularly in terms of using African-centred religions and local cultures as a framework for analysing Jamaican poetry. ${ }^{46}$ Both of our works attempt to position African-Jamaican aesthetics, in part, as a challenge to the British literary

\footnotetext{
${ }^{43}$ Ingrid Reneau, "Dancing the 'Clearing' in African Diaspora Narratives" (doctoral dissertation, Rutgers University, 2000).

${ }^{44}$ Reneau, "Dancing the 'Clearing' in African Diaspora Narratives," 2.

${ }^{45}$ Gilroy's (and others') Black Atlantic theories are significant in that they recognize cultural fluidity and provide a unique lens for looking at the creation of Blackness in the New World; however, they are also limiting, as they neglect the importance of collective cultural and racial experiential memories, a theme many African-Jamaican writers such as Una Marson, Afua Cooper, and Makeda Silvera affirm in their creative work. As a result of this, while the Black Atlantic thesis presents an interesting way of contextualizing the continuous creation of Black identity, it does not completely speak to my research.

${ }^{46}$ Hugh Hodges, Soon Come: Jamaican Spirituality, Jamaican Poetics (Charlottesville: UP of Virginia, 2008).
} 
canon by giving voice to the African-Jamaican working-class as part of a commitment to tracing the decolonization of Jamaica's literary tradition. My analysis of class in the Jamaican context differs somewhat from Hodges', particularly in his reading of Una Marson and Claude McKay. I disagree with Hodges' conclusion, for example, that Marson and McKay employ an African-Jamaican aesthetic superficially because of their middle-class status and anxieties about folk culture. My reading of these two authors leads to a different conclusion.

Finally, another Caribbean diasporic literary scholar who examines many of the same cultural aesthetic aspects as I explore is Carolyn Cooper. ${ }^{47}$ Her interdisciplinary approach draws extensively on indigenous knowledges to contextualize Caribbean cultural production, particularly in her close textual readings of the intersections of Jamaican popular music as literary expression. Her analysis also underscores the significance of African-centred religions, dance, and local language in Jamaican music, in terms both of tracing the historical trajectory of slave and post-Emancipation periods and of documenting connections to West African practices and rituals.

Perhaps the most important intervention of this study is its conscious attempt to incorporate interdisciplinary frameworks that have often been marginalized in the academic realm. For instance, I use a pan-Africanist discourse and rely on local, embodied, and anti-colonial knowledges(s) in my reading of African-Jamaican literature. My theoretical framework includes consideration of vernacular language and folk culture, as well as indigenous philosophical groundings such as Rastafarian sensibility. Such an approach places AfricanJamaican voices at the centre, thereby offering a potentially deeper and more nuanced articulation of the cultural continuum and transformation present in African-Jamaican artforms.

As part of this commitment, I integrate secondary interviews with various dub poets and writers. I also consider secondary scholarly literature and audio recordings to help contextualize the literary works examined. The primary focus, however, is the textual analysis of literary works, which I hope will contribute to a decoding of some of the ways African-Jamaican writers from varied - but connected - locations negotiate day-to-day struggles and questions of

${ }^{47}$ Carolyn Cooper, Sound Clash: Jamaican Dancehall Culture at Large (New York: Palgrave Macmillan, 2004); Cooper, Noises in the Blood: Orality, Gender and the 'Vulgar' Body of Jamaican Popular Culture (Durham N C: Duke UP, 1995). 
identity through the use and retention of African-Jamaican aesthetic parameters. This close (and interdisciplinary) reading of selected poems and works of fiction is instructive because, as Barbara Christian observes, black writers have tended to do a great deal of theorizing in narrative form:

For people of color have always theorized - but in forms quite different from the Western form of abstract logic. And I am inclined to say that our theorizing (and I intentionally use the verb rather than the noun) is often in narrative forms, in the stories we create, in riddles and proverbs, in the play with language, since dynamic rather than fixed ideas seem more to our liking. ${ }^{48}$

It is precisely this play with language (and music and folk culture) in AfricanJamaican diasporic novels and poetry, and the critical theoretical spaces thus revealed that animate this work.

\section{Chapter Overviews}

Chapter 1 of this study attempts a genetic mapping of Jamaican literature by proposing that Jamaican orality is a clear precursor to later scribal production in the country. The chapter looks specifically at early Jamaican work songs, proverbs, and storytelling as significant forms of nascent Jamaican literature. I begin with these early forms of orality because historically vernacular traditions have been foundational to African-derived world-views. Indeed, orality has been seen, in the twentieth century, as a key site from which to build social theory on black identity, both locally and internationally.

Chapter 2 explores how early Jamaican writers, such as Claude McKay and Una Marson, drew on these non-literary traditions to forge what Frantz Fanon termed a "literature of decolonisation." ${ }^{\text {"99 }}$ Here I look at the challenges and concerns early Jamaican writers faced: namely, the struggle to find a national voice and to legitimize African cultural identity. This chapter also provides a brief discussion of dub poetry in Jamaica as an emerging 'radical' body of literary production, which engaged the population and served as an impetus for some diasporic writers.

\footnotetext{
${ }^{48}$ Barbara Christian, "The Race for Theory" (1987), in The Black Feminist Reader, ed. Joy James \& Tracy Denean Sharpley-Whiting (Malden M A \& Oxford: Blackwell, 1999): 12.

${ }^{49}$ Frantz Fanon, The Wretched of the Earth, tr. Constance Farrington, preface by Jean-Paul Sartre (Les Damnés de la terre, 1961; New York: Grove, 1963): 239-40.
} 
Chapter 3 discusses dialogic cultural flows between Kingston, Jamaica, and both London and Toronto, especially in terms of the mediated forms of expression that have helped to create local and diasporic identities for Jamaicans living abroad. The chapter explores the continuity of African Jamaica aesthetics in the work of the UK- and Ontario-based dub poets Afua Cooper, Lillian Allen, Linton Kwesi Johnson, and Benjamin Zephaniah. Also considered is the balance these writers maintain between African-Jamaican cultural retentions and responses to new diasporic spaces. I have chosen the metropolises of London and Toronto as the geographical locations of this study because of their histories as salient sites for African-Jamaican literary production. Dub poetry especially has flourished since the early 1980 s in both of these centres.

Chapter 4 focuses specifically on the female dub poets Afua Cooper, Lillian Allen, and Jean 'Binta' Breeze to illustrate how they harness African-Jamaican aesthetic elements to address issues of race, as well as to reflect on intersections of class and gender. The chapter outlines how these dub poets have incorporated a black feminist sensibility into their work to great effect.

Chapter 5 examines the presence of an African-Jamaican aesthetic in the context of diasporic fiction. Here, I return briefly to McKay's early novel Home to Harlem as a point of entry to consideration of African-Jamaican novelists working outside of Jamaica. McKay's novel reveals interconnections and divergences in the literature of African-Jamaicans inhabiting diasporic spaces. I then turn to the work of two novelists, the Jamaican Canadian Makeda Silvera and the British Jamaican Joan Riley, in order to demonstrate the continuity of African-Jamaican aesthetics in more contemporary fiction. Here again, I am interested in how these writers, working from within diasporic locations, transform and refashion African-Jamaican aesthetic modes.

I conclude by summarizing the main arguments made in the five preceding chapters, rehearsing the study's central focus, and identifying remaining questions that have emerged from the research. Additionally, a brief discussion is offered of some more recent writers of Jamaican descent and how they use an African-Jamaican aesthetic in ways similar to and differently from their predecessors. 


\section{1 \\ - Work Songs, Proverbs, and Storytelling in Jamaican Literary Traditions -}

What seemed like centuries of inactivity and forgetfulness were like seeds within which lay the possibilities for a glorious rebirth. ${ }^{1}$

Nothing will be able to prevent tales, legends, songs come from afar or created, transformed by us, from being a part of us, revealed to us as an exteriorization of our collective self. ${ }^{2}$

T WAS THROUGH THE ORAL TRADITION that I first learned about my Jamaican heritage and culture. As a young child going to school in Canada in the late 1970s and 1980s, I found little mention of Jamaica, the Caribbean or Africa and no easy means of gaining information about them. The public library's bookmobile, which visited my neighbourhood every Tuesday evening, had few books on the regions. Even areas of the curriculum that might easily have been made more inclusive were not. Songs sung in music class, for instance, were alienating because they tended to make references to remote places, peoples, and foods that I could not easily connect with. The songs were always sung in Canadian English and never had the same rhythmic sounds as the ones I was used to hearing at home. You cannot imagine my delight when

\footnotetext{
${ }^{1}$ Olive Lewin, “Traditional Music in Jamaica," Caribbean Quarterly 29.1 (1983): 43.

2 "Contes, légendes, devinettes, chansons, proverbes, croyances, fleurissent avec une exubérance, une générosité et une candeur extraordinaires. Magnifiques matières humaines dont s'est pétri le coeur chaud, la conscience innombrable, l'âme collective"; Jean Price-Mars, "Le folk-lore et la littérature," in Price-Mars, Ainsi parla l'oncle: Essais d'ethnographie (New York: Parapsychology Foundation, 1928): 189, tr. \& quoted in Wilfred G. Cartey, Black Images (New York: Teachers College Press, 1970): 24.
} 
in Grade Six my music teacher introduced two Caribbean folk songs to the class as though she had somehow felt my isolation and detachment. When school ended that day, I excitedly ran home to relate proudly to my family how I was the only child in the class who knew the lyrics to one of the songs and how I even got the opportunity to translate the Jamaican creole words to my classmates. From that day, I looked forward to every music class and was always the first student to raise my hand to request one of the two songs.

The lack of such inclusivity in the Canadian school system as a whole was troubling to me. Having to sit in class day after day and never seeing or hearing about my place of birth or culture often made me feel invisible and insignificant. I was aware of being lost among a sea of white faces that saw me as an outsider coming from some poor, remote, exotic island. It was not until I got home each day that I felt complete and regained some sense of self and equilibrium. The proverbs my mother used in jest, in anger, and at times of grief offered me comfort and access to my cultural history. Beneath every word she uttered in Jamaican creole I found myself. I also looked forward to hearing the duppy stories and riddles that older cousins would share with my siblings and me. The ring games my sisters and I played with the few Caribbean children in the neighborhood during our summer holidays also offered a sense of belonging. Indeed, I often dreaded returning to school in the fall.

Equally, the reggae lyrics that regularly bellowed from our home speakers kept me updated with the transformation of Jamaican creole and schooled me on current and past events in Jamaica and Africa. As Bob Marley said in an interview, "Reggae music is people music [...] reggae music is news [...] is news about yourself, your own history [... things that they won't teach you in school." It was not until later, in my teenage years, that I came to understand that the various forms of orality that were at the root of my home were so empowering and meaningful because they offered me a means to recentre myself in an environment with which I often felt at odds.

The present study's exploration of the African-Jamaican aesthetic and its critical influence on the cultural life and well-being of Jamaicans in the island and its diasporas in part grows out of this early awareness that, for me as a

\footnotetext{
${ }^{3}$ Bob Marley, Time Will Tell (New York: Polygram Videos, 1991).
} 
Jamaican Canadian, orality was as essential to my education as the scribal traditions so valued by educational institutions in the Americas.

\section{Remembering Africa: Orality, Resistance, and the Creation of a People's Narrative}

I return to the framework of indigenous knowledges as a referent for the long historical experiences of people of African descent in the Caribbean, as laid out in the Introduction, to help map and define African-Jamaican aesthetics. Given the near-genocide of some of the first inhabitants of the Caribbean, and notwithstanding the disruption of slavery and colonization, African peoples who arrived in Jamaica brought semantics of their own indigenous knowledges, beliefs, cultural and religious practices, kinship and communal patterns, all of which were then transformed through contact with the local environment and reality to create other indigenous knowledges. The resulting mix of culture is evident in what now constitutes indigenous African-Jamaican aesthetics, such as the oral modes of work songs and proverbs nurtured in Caribbean slavery.

I purposely begin my research with an examination of work songs, proverbs, and storytelling, which I take to be early and instrumental markers of indigenous African-Jamaican aesthetics. My intention here is not to provide an exhaustive overview of Jamaican oral cultures, as the social history of orality in the Caribbean has been amply documented elsewhere, ${ }^{4}$ rather, I aim to rechart its trajectory in the genesis of a national literature. Jamaica's rich legacy of oral cultures offers counter-narratives to dominant discourses of the region by re-imagining the social realities of African-Jamaican communities, retelling African diasporic histories and restoring social agency. Scholars such as Edward Kamau Brathwaite, Honor Ford-Smith, and Carolyn Cooper ${ }^{5}$ have pointed to the importance of orality on Caribbean cultures, which they identify "as the

\footnotetext{
${ }^{4}$ Edward Kamau Brathwaite, History of the Voice: The Development of Nation Language in Anglophone Caribbean Poetry (London \& Port of Spain: New Beacon, 1984); Mervyn Alleyne, Africa: Roots of Jamaican Culture (Chicago: Research Associates School Times Publications, 1996).

${ }^{5}$ Brathwaite, History of the Voice; Honor Ford-Smith, Lionheart Gal: Life Stories of Jamaica Women (Toronto: Sister Vision, 1987); Cooper, Noises in the Blood.
} 
locus of a self-defined critical perspective emerging from Caribbean people's experience. ${ }^{n}$ Brathwaite, for example, argues:

The African Presence in Caribbean Literature cannot be fully or easily perceived until we define the term 'literature' to include the non-scribal material of the folk/oral tradition, which, on examination, turns out to have a much longer history than our scribal tradition, to have been more relevant to the majority of our people, and to have unquestionably wider provenance $[\ldots]$ while a significant corpus of 'prose' and 'poetry' has been created - and read by a few persons in the major Antilles; folk tales, provenance, and chant are found everywhere without fear or favor and are enjoyed by all $[\ldots]$ with this re/vision in mind, we see an African literature in the Caribbean beginning to reveal itself. ${ }^{7}$

It is in the context of Brathwaite's comments that this work begins with an examination of Jamaican oral culture. Here, I focus on a literature in its embryonic oral form before its transition to the scribal in order to subsequently explore the continuity between this oral literature and the works of early African-Jamaican creative writers. In particular, I consider how work songs, proverbs, Anancy folk tales, and duppy stories centralized African-Jamaican narratives and worked as an early non-scribal literary tradition. I also examine how these oral forms were employed and transformed in early diasporic contexts.

For enslaved peoples, the oral tradition served as a primary means of locating themselves amidst forced dislocation much as it functioned for me in my Canadian classroom. Oral narratives represented, and continue to represent, the body of a community's cultural and philosophical thoughts. In the case of Jamaica, Carolyn Cooper broadly characterizes orality thus:

a set of cultural (e.g. obeah, myal, ettu and rival) and linguistic practices (proverbs, riddles, and performance poetry) that defy, challenge and subvert high culture' including books. ${ }^{8}$

This radical notion of orality suggests that

\footnotetext{
${ }^{6}$ Carol B. Duncan, This Spot of Ground: Spiritual Baptists in Toronto (Waterloo, Ontario: Wilfrid Laurier UP, 2008): 15 .

${ }^{7}$ Edward Kamau Brathwaite, "The African Presence in Caribbean Literature" (1974), in Brathwaite, Roots: Essays in Caribbean Literature (Ann Arbor: U of Michigan P): 204.

${ }^{8}$ Cooper, Noises in the Blood, 15 .
} 
it is more than the act of telling and retelling a story. It is indeed the transmission, through the body, of cultural practices long considered inferior, demonic and uncivilized by the dominant culture. ${ }^{9}$

Occupying a cultural space where their native language was forbidden, enslaved Africans in the Caribbean were forced to create new modes of cultural expression. Although they had to accommodate themselves to the European master-tongues, the slaves found ways to manipulate these to their needs, creating what Brathwaite calls "nation languages," which were "influenced very strongly by the African model, the African aspect of our new world/Caribbean heritage. ${ }^{10}$ The realities of oppression and poverty also affected the development of oral languages. African peoples had "to rely on their own breath patterns rather than on paraphernalia like books and museums. They had to depend on immanence. The power within themselves, rather than the technology."1

It is not surprising that the creolization ${ }^{12}$ of language was also closely tied to resistance. In Jamaica, Patwa has been a critical site of anti-colonial struggle. Where written language required education (a right denied to Africans in plantation slavery), the accessibility of Patwa provided African-Jamaicans with a voice and thus with the means to engage in the formation of an indigenous cultural aesthetic. During slavery, this aesthetic took the form of "work songs, gospel, blues, spirituals, mento, shango, shango hymn, and folk tale."13 Ironically, the social conditions of oppression fed the power of this oral-based culture:

\footnotetext{
${ }^{9}$ Cooper, Noises in the Blood, 15.

${ }^{10}$ Brathwaite, History of the Voice, 13.

"Brathwaite, "The African Presence in Caribbean Literature," 273.

${ }^{12}$ Brathwaite described creolization as the "acculturation and interculturation" that occurred among the various ethnic populations of the Caribbean region over time. According to Brathwaite, Caribbean creolization "started as a result of slavery and therefore in the first instance involving black and white, European and African, in a fixed superiority/inferiority relationship." Emancipation, however, changed this process of creolization. Brathwaite, Contradictory Omens: Cutural Diversity and Integration in the Caribbean (Mona, Jamaica: Savacou, 1974): 10-11).

${ }^{13}$ Brathwaite, "The African Presence in Caribbean Literature," 210.
} 
Education in Jamaican society was strictly prohibited, resulting in the continued survival of Jamaican patois and a strong oral tradition that housed much of the cultural capital of Jamaica's African population. ${ }^{14}$

Indeed, the Jamaican oral tradition remains embedded in the richness of the present-day language.

While there are many forms of oral traditions, this chapter, as indicated above, focuses on work songs, proverbs, and storytelling and examines how these functioned as early literary narratives and helped lay the foundation of an African-Jamaican aesthetic. The first section demonstrates the importance of work songs in cultivating local knowledges and acting as a precursor for a Jamaican literary culture.

\section{"Some ah dem a Hollar, some a Bwal": Jamaican Work-Song Traditions}

African-Jamaican work songs initially emerged during the slave era and flourished between the seventeenth and early nineteenth centuries. However, given that enslaved West Africans in Jamaica came from an almost entirely oral culture and had no fixed literary forms, it was only at the turn of the twentieth century that these work songs (along with proverbs and Anancy stories) began to be documented by British folklorists such as Walter Jekyll in his book Jamaican Song and Story. ${ }^{15}$ As in other parts of the Caribbean region and the southern USA, Jamaican work songs played a number of important roles. On a practical level, the songs were employed to maintain a steady pace and coordinate the speed and repetition of group work, but they also provided a means of social and political commentary. Using the vernacular of the everyday, the songs were a way for African-Jamaicans to articulate their experiences. The songs recounted hardships, recorded aspirations for freedom, and expressed both covert and overt opposition to their situation. Additionally, work songs provided a means of articulating an African-Jamaican cultural identity and keeping alive the collective memory of Africa. ${ }^{16}$

\footnotetext{
${ }^{14}$ Campbell, "Indigenous Knowledge in Jamaica," 196.

15 Walter Jekyll, Jamaican Song and Story (1907; Mineola NY: Dover, 1966).

${ }^{16}$ Many work songs were sung not just in creole but also in African languages, mainly so plantation owners would not know that they were singing about their terrible conditions or
} 
Indeed, African cultural patterns were embedded in work songs. In the song "Chi Chi Bud," for example, the lead singer employs call and response, a West African feature common in African-Jamaican songs. Here the leader calls out rhythmically an almost infinite list of bird names to keep the crew chopping, digging or cutting:

Chi Chi bud O'

Dacta bud a cunnin bud

Hard bud fe dead

Cling cling, groun' dove, hawk, stark

John-crow, ducky

Today, John-to wit, hoppin dick... ${ }^{17}$

The crew, in turn, responds with the chorus "Some a dem a hallar some a bawl." The rhythm of language in this and other work songs anticipates speech rhythms in later Jamaican music styles such as kumina, ring games, mento, reggae, and dancehall. ${ }^{18}$ As with many work songs, the surface sense of the lyrics conceals another layer of meaning. Here the litany of birds is in fact a list of people, white and black, with whom the singers are all familiar and are ridiculing. ${ }^{19}$ Similarly, in the song "John Crow," the name of the bird is used for a person singled out for teasing or ridicule:

John Crow say ing cyan wuk pon Sunday

Cyan wuk cyan wukpon Sunday

Tink a lie me tell, kill you mahga [skinny] cow

Tink a lie me tell, kill you mahga cow

John Crow saying cyan wuk, ing cyan wuk,

Ing cyan wuk pon Sunday.

John Crow saying a decent sumadi.

ridiculing their masters; Amber Wilson, Jamaica: The Culture (Stevens Point WI: Worzalla, 2004): 22; Lewin, "Traditional Music in Jamaica," 33, 36.

${ }^{17}$ Martin Mordecai \& Pamela Mordecai, Culture and Customs ofJamaica (Westport C T: Greenwood, 2001): 137-38.

${ }^{18}$ Peter Manuel with Kenneth Bilby \& Michael Largey, Caribbean Currents: Caribbean Music from Rumba to Reggae (Philadelphia PA: Temple UP, rev. \& expanded ed. 2006): 186.

${ }^{19}$ Mordecai \& Mordecai, Culture and Customs ofJamaica, 138. 
John Crow, say ing a study fe teacher.

John Crow say ing a dry lan'touris. ${ }^{20}$

By using the 'John Crow', a turkey vulture and scavenger, as a metaphor for the aspiring Jamaican middle class, the song importantly critiques the class structure of Jamaican society, where the labour of the black working class is often denigrated in favour of the aspirations of a predatory middle-class. Because the colour of the 'John Crow' derogatorily connotes blackness, this critique of middle-class assumptions is also linked to a critique of race and the tendency to devalorize blackness even among black people themselves. ${ }^{21}$

Researchers have also noted the centrality of music in offering enslaved Africans a safe means of sharing information and providing cultural critique. ${ }^{22}$ Commenting specifically on work songs, Paula Burnett explains that "the slaves were forbidden to talk to each other as they worked. But the slave overseers, or bushas as they were called, did not mind if the slaves sang. ${ }^{n 23}$ Furthermore, as Lewin notes:

Our African ancestors seem to have known instinctively how to use sound to maneuver the boss and his carefully engineered system. Music became an important means of expression and communication. Ideas, news and comments that could not be spoken [... or written down], could be sung. ${ }^{24}$

Lewin's comments further indicate how music transmitted news to people, a notion Bob Marley echoes in his reflections about reggae music.

In his work on the history of black music in a US context, Amiri Baraka also traces the links between early African-derived work songs and later music forms such as the blues, ragtime, boogie-woogie, jazz, and bebop. ${ }^{25}$ Other aca-

${ }^{20}$ Olive Lewin, Forty Folk Songs ofJamaica (Washington DC: General Secretariat of the Organization of American States, 1973): 33 .

${ }^{21}$ It is intriguing that this Caribbean onomastic tradition differs from the 'jumpin' Jim Crow' motif of US-American plantation slavery, where it was associated with song-and-dance routines performed by slaves for the entertainment of their masters (and later became the shorthand for the segregated South).

${ }^{22}$ Michael Burnett, Jamaican Music (Oxford: Oxford U P, 1982).

${ }^{23}$ Burnett, Jamaican Music, 31 .

${ }^{24}$ Olive Lewin, Rock It Come Over: The Folk Music ofJamaica (Kingston, Jamaica: U of the West Indies P, 2000): 56 .

${ }^{25}$ Amiri Baraka, Blues People: Negro Music in White America (New York: Morrow Quill, 1965). 
demics, however, fail to fully acknowledge the centrality of Africa-centred indigenous musical forms in the diaspora. Paul Gilroy's discussion of the role of music in the development of diasporic black identity, for instance, neglects the African connections underpinning diasporic music phenomena. ${ }^{26}$ Indeed, Gilroy's Black Atlantic theory does not significantly take into account black cultural memory drawn from Africa prior to the slave trade and kept alive. For Gilroy, slavery is conceived as the crucial moment defining North American black experience. In this way, the birth of modernity and modernism is treated as an early-nineteenth-century phenomenon. When looking at black audio production, in this case Jamaican music, it is crucial to recognize the African indigenous foundations upon which it is built. As Lewin reminds us, "to understand Jamaica's traditional music one must understand the total environment of the people who create, adapt and use it. ${ }^{27}$

Importantly, the Jamaican work-song tradition extended beyond the nation's borders as workers travelled to other places in the region. For instance, Louise Cramer reports on the songs of African-Jamaican men contracted to work on the Panama Canal. ${ }^{28}$ The transformation of the songs to absorb the realities of a new environment is a good example of the diasporic shifting of local knowledges, a topic I return to in later chapters. The worker in the song "Come out a Merica Cut" reflects the benefits of working on the "American cut" (the Canal) because the job pays a much higher wage than the "one bit a day" earnings in his own country of Jamaica:

Before me work fe [for] bit a day

Before me work fe bit a day

Before me work fe bit a day

Me wid [would] come out a Merican Cut,

Dem a bawl [they cry], oh, come out a

Merican Cut,

\footnotetext{
${ }^{26}$ Paul Gilroy, The Black Atlantic: Modernity and Double Consciousness (Cambridge MA: Harvard UP, 1993).

${ }^{27}$ Lewin, "Traditional Music in Jamaica," 33.

${ }^{28}$ Louise Cramer, "Songs of West Indies Negroes in the Canal Zone," California Folklore Quarterly $15 \cdot 3$ (July 1946): 253 .
} 
Dem a bawl, oh, come out a

Merican Cut. ${ }^{29}$

By demanding the right to travel to earn fair wages, the worker critically takes up the notion of 'America' as a shared diasporic space. This, again, reinforces the way in which orality functions as economic and political critique. These indigenous knowledges are constantly moving to and within different spaces and are responding to the demands of the specific environment.

While work songs were empowering in their literary expressiveness and verbal resistance to colonial oppression, their approach to gender was sometimes troubling. Chauvinist ideas were pervasive in many of the texts and some of the songs invoked unsettling images of black women as nagging and golddigging. In "Ooman a Heavy Load," for instance, African-Jamaican women are presented as financially demanding and burdensome (yet sexually complimentary when the money comes in):

Woman is a heavy load, hi

Woman is a heavy load, hi

Woman is a heavy load.

O wen Satieday mornin'com, hi

Wen de money no nuff, hi

Wen de money no nuff, hi

Wen de money no nuff, hi

Wah dem neva go out com back.

Wen de money nuff, hi

Wen de money nuff, hi

Wen de money nuff, hi

Den dey call you honey comb, hi

Wen de money nuff, hi

Why dey call yo sugar stick, hi. ${ }^{30}$

In the work song "Oman is a people," women are similarly depicted as "niggling" and never satisfied, even when their men 'bring home the bacon':

Oman is a people

Grumble too much

Oman is a People

${ }^{29}$ Cramer, "Songs of West Indies Negroes in the Canal Zone," 253.

${ }^{30}$ Cramer, "Songs of West Indies Negroes in the Canal Zone," 256. 
Grumble too much

Oman is a People

Grumble too much

Oman is a People

Grumble too much

Dem a walk dem a grumble

Grumble too much

Dem a nyam [eat], dem a grumble. ${ }^{31}$

While many work songs offered a powerful critique of the class and colour relationships in their societies, they often neglected, therefore, to take up discussion of gender in the same way and seemed to rely instead on the same patriarchal discourses that framed the very attitudes of class and colour they sought to challenge. Songs like these failed to acknowledge the hardships faced by Jamaican women trying to support families and communities with few resources.

Not all work songs followed this pattern. The mento song "Linstead Market," for example, speaks to the uphill struggle of female commercial labourers who have to rely on the sale of agriculture goods in the market to earn a living:

Carry mi ackee [pear-shaped fruit] go Linstead Market

Not a quatty [small coin] worth sell (repeat the lines)

Oh Lord not a bite

What a Saturday night? (repeat)

Everyboady come feel up feel up

Not a quatty worth sell (repeat)... ${ }^{32}$

The song continues to be relevant today, reflective as it is of the plight of contemporary female commercial street vendors (or higglers) who continue to rely on the informal labour milieu of the market for their economic survival. Another song responding to the challenges faced by women in the labour market was "Day dab light / Day in Dawning," which was sung by Jamaican women after a night of loading bananas on ships at the wharf. ${ }^{33}$ This song was

${ }^{31}$ Daryl Cumber Dance, Folklore from Contemporary Jamaicans (Knoxville: U of Tennessee P, 1985): 175-76.

${ }^{32}$ Joanne Martin, More Folk Strings for Solo Violin (Miami F L: Warner Bros, 2003): 18.

${ }^{33}$ Sean Sheehan \& Angela Black, Jamaica (New York: Benchmark, 2nd ed. 2004): 107. 
later re-fashioned by Harry Belafonte and became one of his most famous as the mento song "Mr Tallyman" or "Banana Boat Song."

Still, as Henrice Altinck rightly notes, little scholarly attention has been paid to songs related to Jamaican women in the slave era. Many of the songs sung by slave women were sung in private, hence remained undocumented. ${ }^{34}$ This is likely, in part, a reflection of the division of labour at the time, which saw women as responsible for tasks such as house-cleaning in addition to work outside the home, as seen in the following song:

Good mawnin' Missa Potta

Good mawnin' to you sah

A come to lodge a complain to you now, sah

A plant a piece o' red pea

A red sally lan'

Mary Jane and pigen come eat $\mathrm{i}$ out sah

Come out a' me yahd, me nevva call you yah

Come out a' me yahd, me nevva call you yah

For you house rent money no done pay fah. ${ }^{35}$

Work songs, however, did more than just relate the sufferings and frustration of African-Jamaican workers; they were also imbued with lightheartedness and a sense of economic pride and resiliency. In the short-story collection When Me Was a Boy, the playwright and actor Charles Hyatt recounts the buoyancy that workers displayed through the work songs he heard as he travelled to school each morning in the 1930s:

Well if anything can mek mi late fi school or even absent is if on mi way I come 'cross a group of men wid pix axe diggin'. This is the prettiest thing to behold an to hear. Only NDTC [the National Dance Theatre Company] could a perform anything look so good... Then of course, the more the people enjoy it the better the diggers perform. ${ }^{36}$

Hyatt's recollection points to the power and continued significance of work songs in post-emancipation Jamaican society. They provided a framework for

${ }^{34}$ Henrice Altink, "More than Producers and Reproducers: Jamaican Slave Women's Dance and Song," in Beyond the Blood, The Beach and the Banana: New Perspectives in Caribbean Studies, ed. Sandra Courtman (Kingston, Jamaica: Ian Randle, 2004): 71-90.

${ }^{35}$ Lewin, Rock It Come Over: The Folk Music of Jamaica, 14.

${ }^{36}$ Charles Hyatt, When Me Was a Boy (Kingston: Institute of Jamaica Press, 1989): 61. 
early narratives and literacy in the Jamaican population, in the same way calypso, reggae, and dancehall music would do in later periods. The songs offered African-Jamaicans a conduit through which to channel their local and indigenous knowledges (language, proverbs, riddles, etc.) in order to voice their views on social conditions and articulate cultural resistance.

Interestingly, although oral traditions, such as work songs, were so prevalent in the Caribbean and existed long before the social and cultural movements of nationalism began, they were not taken up as a subject in Afro-Caribbean scribal literature until local nationalist and global pan-African movements emerged. In the 1930s and 1940s, Caribbean literature began moving away from the European literary tradition, with the integration of folk traditions and orality being seen as instructive to an 'authentic' Caribbean identity. This shift signalled an aspiration to African consciousness and mirrored the nationalist project emerging in the region. Literary critics argue that these work songs, along with other oral forms, were clear precursors of early African-Jamaican literary works. ${ }^{37}$

We see this early intersection of the oral and scribal in Evans Jones's poem "Song of the Banana Man" (1952), which is clearly linked to earlier work songs and, like them, articulates the work experiences of African-Jamaican men and women:

I leave m'yard early-mornin time

An' set m'foot to de mountain climb,

I ben m'back to de hot-sun toil,

An m'cutlass rings on de stony soil,

Ploughin an weedin, diggin an plantin

Till Massa Sun drop back o John Crow mountain,

Den home again in cool evenin time,

Perhaps whistling dis likkle rhyme,

Praise God and m'big right han

I will live an die a banana man. ${ }^{38}$

${ }^{37}$ Sarah Lawson Welsh, "Experiments in Brokenness: The Creative Use of Creole in David Dabydeen's Slave Song” (1996), in The Routledge Reader in Caribbean Literature, ed. Alison Donnell \& Sarah Lawson Welsh (London: Routledge, 1996): 416.

${ }^{38}$ Penguin Book of Caribbean Verse in English, ed. Paula Burnett (Harmondsworth: Penguin, 1986): 223 . 
Jones uses the image of the banana man to provide social commentary on the exploitative nature of the economic conditions faced by agricultural workers. Even natural imagery is harnessed to suggest memories of slavery days (the brutal sun as plantation overseer ${ }^{39}$ ). He also points to the tensions between the banana man's reality and the voyeuristic gaze of tourists with very little knowledge of the lives of everyday Jamaicans, a theme also explored in Una Marson's poem "In Jamaica" ${ }^{40}$ and in the texts of contemporary reggae singers and dub poets. Jones recalls this in his poem:

Touris, white man, wipin his face,

Met me in Golden Grove market place.

He looked at m'ol' clothes brown wid stain,

An soaked right through wid de Portlan rain,

He cas his eye, turn up his nose,

He says, 'You're a beggar man, I suppose?'

He says, 'Boy, get some occupation,

Be of some value to your nation.'

I said, 'By God and dis big right han

You mus recognize a banana man. ${ }^{, 4}$

"Song of the Banana Man" also integrates African-Jamaican spirituality and folk culture to further depict the lived experiences of the banana planters. While Jones primarily uses a British literary form, as in his preference for mainly Standard English, he introduces some approaches that were commended in literary circles of the time for capturing Jamaican vernacular and folk culture. He did this in part by using the work song as a starting point. Earlier poets, such as Claude McKay, also mimicked the work-song form; however, Jones took this a step further by employing diverse forms of oral culture and African-Jamaican aesthetics in his writing. ${ }^{42}$ The legacy of work songs would

${ }^{39}$ The suddenly extinguished tropical light contrasted felicitously with the crow-like darkness of Jamaica's lateral northern range, the name itself historical and drawn from folk tradition.

${ }^{40}$ Marson, Heights and Depths (Kingston: The Gleaner, 1931): 82.

${ }^{41}$ Penguin Book of Caribbean Verse in English, ed. Burnett, 222.

${ }^{42}$ The names given to the Banana Man's friend Zekiel (Ezekiel) and the comical "Duppy Son" (223) capture a cultural element and common Jamaican practice of assigning nicknames without explanation or as a bearer of symbolic meaning. 
also become influential in African-Jamaican popular music. ${ }^{43}$ The songs of the reggae icon Bob Marley and Burning Spear, for instance, draw on work-song form to express exploitative working conditions in an urbanized postcolonial context. And just as the work songs became an important means of expressing Jamaican social conditions and serving as a carrier of Jamaican local cultures, proverbs would assume a similar role in Jamaican society.

\section{"This is a Proverbs from Mi Ole Time Granny": Proverbs and the Jamaican Oral Tradition}

African-Jamaican proverbs were another early, and significant, form of oralbased literature. Like work songs, proverbs acted as a means of communicating important social messages, commenting on socio-political issues, and expressing an African-Jamaican world-view. Hugh Hodges emphasizes the important social function of proverbs with his observation that "Jamaica proverbs do as a genre, reflect the people's struggle with oppression." ${ }^{44}$ Drawing on folk culture, proverbs made use of the Jamaican vernacular and local knowledges; at the same time, many of the points of reference signalled continuity with Africa. Indeed, many African-Jamaican proverbs have roots in West African literary and cultural forms of expression; "many of the Jamaican sayings are obviously derived from a special meaning given to proverbs in some West African cultures". 45

In the introduction to her book Jamaican Proverbs, Martha Beckwith also comments:

It is to be noted how many of the proverbs apply to poverty, hunger, and injury, and want. Love is not celebrated nor is heroism or beauty [...]. It is the fate of the folk who are put upon by their better and who smart under injury which is expressed with an almost uncanny justness of observation; as if, by

\footnotetext{
${ }^{43}$ This also occurred in other diasporic contexts - see, for example, the American Sam Cooke's hit song "Chain Gang," which also used a work-song template.

${ }^{44}$ Hodges, Soon Come: Jamaican Spirituality, Jamaican Poetics, 65.

${ }^{45}$ G. Llewellyn Watson, Jamaican Sayings: With Notes on Folklore, Aesthetics, and Social Control (Gainesville: UP of Florida, 1991): 11.
} 
generalizing the experience of misery and poverty, each man became dignified in his own eyes. ${ }^{46}$

While Beckwith captures the thematic essence of many proverbs, she fails, however, to read the totality of the local culture that informs them and thus "overlooks the $w a y^{47}$ proverbs talk about poverty, hunger and injury." ${ }^{48}$ It may be that Beckwith's outsider perspective prevented her from grasping (or conveying) all of the implications of the black experience encapsulated in proverbs. As Carolyn Cooper notes,

Beckwith's judgment appears to be based on a limited understanding of the Jamaican psyche, a failure to recognize the way humour permits us to 'tek bad tings mek joke' ${ }^{49}$

Cooper's perspective underscores the function of proverbs as a central repository of African-Jamaican indigenous knowledges. This centrality is displayed in the seminal poet and folklorist Louise Bennett's "Jamaica Philosophy":

Dictionary say dat philosophy mean 'the general principles governing thoughts and conducts', 'a study of human morals and character'... Dem-deh is we ole time Jamaica proverbs, an dem got principles governin thoughts an conducts an morals an character, like what dictionary seh..$^{\circ}$

Bennett is well aware of the disruption to hegemonic understandings of philosophy embodied in this declaration as indicated by the question she has another character (Muches) pose to Aunty Roachy: "How you coulda put deestant wud like philosophy wid de ole jamma bad talkin proverbs-dem?" ${ }^{11}$ Bennett's observations, a pungently and sophisticated 'pre-phrasing' of VèVè Clark's notion of diaspora literacy, indicates how African-Jamaicans have consciously used and understood proverbs as a central philosophy in their lives, and pointedly avoids obeisance to European prescriptions.

In contrast to work songs, which were mainly sung during labour, proverbs permeated day-to-day living. They served not only as a philosophical system

\footnotetext{
${ }^{46}$ Martha Warren Beckwith, Jamaican Proverbs (Poughkeepsie NY: Vassar College, 1925): 90.

${ }^{47}$ My italics.

${ }^{48}$ Hodges, Soon Come: Jamaican Spirituality, Jamaican Poetics, 65.

${ }^{49}$ Cooper, Noises in the Blood, 23.

${ }^{50}$ Louise Bennett, Aunty Roachy Seh (Kingston, Jamaica: Sangster's, 1993): 7 .

${ }^{51}$ Bennett, Aunty Roachy Seh, 7.
} 
but also as a non-scribal mode that would later find its way into Jamaican literature and music. For the purpose of this brief section, I focus on proverbs in poetry, especially as found in Bennett's writings. Bennett played a crucial role in reintroducing and legitimizing oral folk knowledge during a time when such a literary approach was often seen as inferior. Bennett's use of this approach, across the span of the written form, allowed her to speak directly to Jamaicans, thus promoting self-pride and a holistic sense of cultural identity. In later years, her work travelled with her to other sites in the diaspora, where it took on new layers of meaning. While Bennett has a personal collection of over seven hundred proverbs ${ }^{5^{2}}$ my intention here is to focus on a few of her works in order to highlight her use of proverbial expression and common sayings and to contextualize how such orality can shift within and between literary spaces to give authority to indigenous black knowledges.

In her poetry collection Jamaica Labrish (1966), Bennett uses proverbs to reclaim ancestral voices and to speak to the specificities of everyday Jamaican life. Commenting on the book, Carolyn Cooper writes:

The metaphorical proverb recurs in the poetry and dramatised narratives of Louise Bennett to fulfil two vital functions. [...] Thematically, the proverb provides conclusive evidence of the socially recognized truth of the argument that a particular Bennett persona articulates; structurally, the metaphorical proverb employs graphic imagery derived from everyday Jamaican life as the vehicle for social commentary. In both subject and structure the metaphorical proverb affirms Bennett's umbilical connection to [the] matrix of oral Jamaican folklore..$^{53}$

This umbilical connection is clearly demonstrated in "A Merica," a poem about Caribbean migration to the USA in the 1940 s. Bennett begins with the proverb "Every secky [beggar] got him jeggeh [bundle of twigs] / Every puppy got im flea" ${ }^{n 4}$ to reaffirm the Jamaican tradition of holding onto cultural wisdom across

${ }^{52}$ As pointed out by Mervyn Morris, "Introduction" to Louise Bennett: Selected Poems, ed. Morris (Kingston, Jamaica: Sangster's, 1982): iii-xix. Carolyn Cooper provides a list of forty-seven of the proverbs, animal and general, found in Bennett's poems, in her essay on the topic: see "Proverb as Metaphor in the Poetry of Louise Bennett," Jamaica Journal 17.2 (May 1984): 21-24.

${ }^{53}$ Cooper, Noises in the Blood, 21.

${ }^{54}$ Louise Bennett, "A Merica," in Bennett, Selected Poems, ed. Morris, 109; Bennett, Jamaica Labrish (Kingston, Jamaica: Sangster's, 1966): 180. 
space and time, thus enabling the community to survive in new environments. The persona goes on to highlight the strong sense of community among Jamaicans living in US diasporic metropolises: "Jane seh she meet so much ole frien / Wen she stroll dung New York / Dat she feel like is dung King Street / or Luke Lane she dah walk." ${ }^{55}$ Here the persona speaks of streets in Jamaica to call attention to the way they still have relevance in her everyday life. This cultural grounding of the proverb at the beginning of the poem and the Jamaican streets at the end allow the persona to successfully navigate her new environment. (Later poets, such as Afua Cooper and Jean 'Binta' Breeze, will build on this use of proverbs as a means of literary expression and cultural survival in new diasporic spaces.) Bennett's poem "Proverbs," not surprisingly, further exemplifies her commitment to this literary means. In the following three stanzas of the poem, I have italicized the proverbs:

When ashes coal dawg sleep in deh

For sence Mah dead, yuh see,

All kine a ole black nayga start

Teck liberty wid me.

Me no wrap wid dem, for me

Pick an choose me company:

Ma always tell me seh: 'Yuh sleep

Wid dawg yuh ketch him flea'

Me know plenty a dem no like me,

An doah de time so hard

Me kip fur from dem, for 'Cockroach

No bizniz a fowlyard" ${ }^{\prime 56}$

It is important to point out here that not all proverbs are metaphorical in meaning; they can also carry literal messages and instruction. Nonetheless, all of their meanings are tied to a particular context: that is say, proverbs spring from intimate cultural familiarity with a specific location, to which folk-based listeners and readers respond.

\footnotetext{
${ }^{55}$ Bennett, Selected Poems, 110; Bennett, Jamaica Labrish, 180.

${ }^{56}$ Bennett, "Proverbs" (1943), in Bennett, Jamaica Labrish, repr. in Bennett, Selected Poems, ed. Morris, 53-54.
} 
Bennett's poem "Back to Africa," on the other hand, complicates the discourse around origin and roots, again showing the significance of using proverbs to make sense of everyday realities. Here she plays on a common expression, "Yuh haffe come from some weh fus / Before yuh go back deh!"57 to acknowledge that, while African-Jamaican culture has its origins in West Africa, the rupture of slavery led to the metaphorical planting of new cultures in a new land, resulting in the birth of indigenous and specifically Jamaica-based knowledges, which it would be futile (as in the repatriation movement of the 1920s4os spearheaded by Marcus Garvey and in the reverse diaspora of Rastafari to Ethiopia) to see as less 'original'.

Some critics have asserted that Bennett's poem "Back to Africa" suggests that a connection to Africa is irrelevant, ${ }^{58}$ but I believe it is more correctly read as supporting Mervyn Alleyne's notions of African cultural continuity in the Caribbean. Alleyne, in tracing significant cultural continuities from Africa to Jamaica, rejects the idea that Caribbean cultures are primarily "a reaction to Whites and to slavery. ${ }^{59} \mathrm{He}$ argues that Africans who arrived in the New World' continued to rely on knowledges from their homelands: "acquired skills, memories, habits, predispositions, cognitive orientation, and language - all beneath the surface of consciousness, and persistent even in the worst conditions. ${ }^{60}$ Alleyne goes on to stress that African continuities were especially strong in the areas of religion, music, and language. Bennett's own emphasis on African-Jamaican oral traditions and proverbs demonstrates this kind of continuity: "between yu and de Africans / is great resemblance." ${ }^{\text {"61 }}$ If Bennett has any argument with Alleyne's vision, it is only a matter of degree; she sees clear ties to African cultures in Jamaica but also recognizes their transformation over

57 Bennett, "Back to Africa" (wr. 1947), in Bennett, Jamaica Labrish, 214, repr. in Bennett, Selected Poems, ed. Morris, 104.

${ }^{5}$ Denise DeCaires Narain, "The Lure of the Folk: Louise Bennett and the Politics of Creole," in Narain, Contemporary Caribbean Women's Poetry: Making Style (New York \& London: Routledge, 2002): 77; Simon A. James Alexander, Mother Imagery: The Novels of Afro-Caribbean Woman (Columbia: U of Missouri P, 2001): 97.

59 Alleyne, Africa: Roots ofJamaican Culture, 19-20.

${ }^{60}$ Africa: Roots ofJamaican Culture, 6.

${ }^{61}$ Bennett, Jamaica Labrish, 214. 
time in the context of a new land and contact with other European and ethnic groups.

As Bennett insists in another text, "Jamaica people have a whole heap of culture and tradition and birthright han dung [handed down] to dem from generation to generation. ${ }^{\text {} 22}$ This signals a Jamaican cultural link to a place of origin, stressing the importance of understanding this past in order to thrive in a new land, thus echoing Marcus Garvey's well-known statement, "If you don't know where you're from, you can't know where you're going." It also implies the specific need for this kind of cultural grounding, given the alienation black diasporic peoples have experienced in the New World. The problem for critics is that, while Bennett clearly acknowledges ties to Africa, she also claims Jamaica as a geographical home-space: "noh tell nobody sey / yu dah-go fe see yuh homeland / for a right de so yuh deh"! ${ }^{63}$

Bennett's poetry also continues the tradition of social and economic critique central to the work songs. In "Dutty Tough," proverbs capture the hardship of rural black Jamaicans and illustrate their relationship to the land. ${ }^{64}$ The title conveys the ongoing "sufferation" ${ }^{\text {" }} 5$ of Jamaica's urban and rural poor in a national economy at the time largely tied to agricultural production:

Sun a shine but tings no bright

Doah pot a bwile, bickle [cooked food] no nuff

River flood but water scarce, yaw

Rain a fall but dutty [earth] tough! ${ }^{66}$

In their analysis of "Dutty Tough," Cundall and Anderson focus on Bennett's use of proverbs to indicate ties to the land. The poem

highlights the ontological foundations of indigenous knowledge put to use by rural populations in Jamaica who navigate their existence with land through an intimate and dialectical relationship. ${ }^{67}$

\footnotetext{
${ }^{62}$ Bennett, Aunty Roachy Seh, 7.

${ }^{63}$ Bennett, Jamaica Labrish, 215 .

${ }^{64}$ Interestingly, the proverb makes use of the Twi word 'dutty', meaning soil or earth, thus emphasizing connection to land; Frederick G. Cassidy \& Robert B. Le Page, Dictionary ofJamaican English (Mona, Kingston: U of the West Indies P, 2nd ed. 2002): 167 .

${ }_{5}$ 'Sufferation' is a Caribbean English word used to describe conditions of extreme adversity.

${ }^{66}$ Bennett, Jamaica Labrish, 120.

${ }^{67}$ Frank Cundall \& Izett Anderson, Jamaica Proverbs and Sayings (Shannon: Irish U P, 1972): 64.
} 
"Grung nebber forsake him massa," is another common Jamaican proverb also associating hardship with the land. Like "Dutty Tough," the proverb uses the ground or earth to represent the idea of suffering that originates in an indigenous relationship with the land and social environment. Walter Ong elaborates on how proverbs act as a cultural frame of reference:

In a primarily oral culture, to solve effectively the problem of retaining and retrieving carefully articulated thought, you have to do your thinking in mnemonic patterns, shaped for ready oral recurrence. Your thought must come into being in heavily rhythmic, balanced patterns, in repetitions or antitheses, in alliterations and assonances, in epithetic and other formulary expressions, in standard thematic settings [...] in proverbs which are constantly heard by everyone so that they come to mind readily and which themselves are patterned for retention and ready call. ${ }^{68}$

Ong's observations validate the significance of Bennett's use of proverbs. Notwithstanding her humorous use of Jamaican language to convey social commentary, Bennett also entwines serious thoughts with the proverbs in her texts. For Bennett, proverbs carry deep meaning and are not just "jamma bad talkin," as her character Muches claims. Clearly, in oral/folk culture, thoughts are lodged within sound, just as much as words on a page.

These selected pieces of Bennett's work highlight how her characters "speak in proverbs and affirm their claim to an oral legacy of "culture an' tradition an' birthright'." ${ }^{69}$ Bennett's proverbs carry textual and material meanings that are tied to a particular context, taking into account their indigenous location. They are also evidence of a non-scribal literary tradition, which Bennett will later insert into a 'formal' literary and scribal culture. Perhaps the African-American author Zora Neale Hurston summed up the power of proverbs in the lives of African diasporic peoples best:

Oh, I won't forget. I won't forget anything that you have ever taught me, the saying, and the proverbs and all. They have helped a lot [...] You are to right to listen to proverbs. They are short sayings made out of long experience..$^{70}$

\footnotetext{
${ }^{68}$ Walter Ong, Orality and Literacy: The Technologizing of the Word (London: Methuen, 1982): 34 .

${ }^{69}$ Cooper, Noises in the Blood, 9.

${ }^{70}$ Zora Neale Hurston, Moses, Man of the Mountain (1939; New York: HarperPerennial, 1991 ): 80.
} 
For Bennett and other African-Jamaican writers and artists, proverbs are the encapsulated expression of a constant tie to their cultural homes borne of "long experieence." Proverbs are never left behind. Instead, with the help of diasporic writers like Bennett, they migrate overland and overseas, keeping the wisdoms of African-Jamaican folk culture alive and meaningful.

\section{"Jack mandora, mi nuh choose nun": The Art of Storytelling}

This last section offers a brief discussion of storytelling and its significance in orality for African-Jamaicans. Like their African griot ancestors, storytellers were understood as instrumental in keeping knowledge alive through their sharing of cultural and symbolic folktale narratives. Jamaican folk stories are closely linked with various African ethnic groups including the Ashanti, Igbo, and Yorùbá. ${ }^{71}$ West Africa-derived folklore characters such as Anancy, duppies, and watermaids (river mummas) spoke to the Caribbean context and would appear in later written literature to express a local African-Jamaican aesthetic.

Anancy stories are arguably Jamaica's best-known and longest-existing examples of the oral storytelling tradition. With their historical West African roots, Anancy narratives confirm Elabor-Idemuda's observation that many folktales survived the slave trade intact. ${ }^{72}$ Anancy is a spider trickster and tales about his ability to survive through cunning and wit continue to entertain and teach valuable lessons. They also respond, in part, to the experience of slavery. As Richard Burton explains,

The essential theme of Anancy story [...] is the cultivating of the powerful by the weak $[\ldots]$ the use of tactics, or a whole repertoire of oppositional devices on the part of the weak first to evade and then to manipulate in their favor a power that, if used directly can and must destroy them [...] Anancy's realm is the real of the polymorphous, perverse, of endless deviation, deflection, switching roles $[. .$.$] the storyteller's art is likewise one for subterfuge and$

${ }^{71}$ Keith Thompson, Life in the Caribbean (Dar es Salaam: New Africa Press, 2010): 273. Some European tales were also brought to the island from England.

${ }^{72}$ P. Elabor-Idemudia, "The Retention of Knowledge of Folkways as a Basis of Resistance," in Indigenous Knowledges in Global Contexts: Multiple Readings of Our World, ed. George J. Sefa Dei, Budd L. Hall \& Dorothy Goldin Rosenberg (Toronto: U of Toronto P, 2000): 103. 
multiple meanings, so that any Anancy story operates polysemically, with one meaning say for children another for adults $[\ldots]$ and still another for outsiders, particularly outsiders who are white. ${ }^{73}$

Anancy allegories centre on the spider's ability to outsmart 'massa' in the game of survival, thus reflecting the daily realities of slavery. As the historian Lawrence Levine observes, enslaved Africans in the New World accommodated "the structure and message of their tales to the compulsions and needs of their present situation. ${ }^{74}$ Indeed, enslaved Africans identified with Anancy as a "mythical manipulator of the mighty, a vicarious avenger of the humiliation they felt in everyday life. ${ }^{75}$ This power, however, was often hidden beneath a surface of weakness, so that

whites who $[\ldots]$ were present at the telling of an Anancy story would take the pleasure in a protagonist whose bowings and scrapings before authority caricatured the already caricatural act the slaves played out daily before them..$^{6}$

This narrative duplicity provided moral and cultural agency, enabling enslaved and free Africans to draw on ancestral wisdom and speak among themselves, thus making sense of their world. This narrative duplicity also allowed the audience, as the Jamaican expression goes, to 'tek bad sinting mek joke'. This proverbial notion of laughing at something troubling gestures at how the community used humour to cope with and respond to adversity.

Anancy's survival over time is impressive considering that, as with many African folk traditions, Caribbean educational institutions, until quite recently, rejected Anancy stories wholesale. Nevertheless, these stories persisted in Jamaican folk culture and in the modern era have been extensively adopted in the scribal literary form. Numerous authors, including Andrew Salkey, Dennis Scott, Edward Kamau Brathwaite, and Erna Brodber have made use of wily Anancy in everything from children's stories to novels and non-fiction. In particular, several of Louise Bennett's poems play upon the trickster theme of

\footnotetext{
${ }^{73}$ Richard D.E. Burton, Afro-Creole: Power, Opposition and Play in the Caribbean (Ithaca NY: Cornell UP, 1997): 63 .

${ }^{74}$ Lawrence W. Levine, Black Culture and Black Consciousness: Afro-American Folk Thought from Slavery to Freedom (Oxford \& New York: Oxford UP , 2007): 90.

${ }^{75}$ Burton, Afro-Creole:Power, Opposition and Play in the Caribbean, 64.

${ }^{76}$ Afro-Creole: Power, Opposition and Play in the Caribbean, 64.
} 
Anancy. Carolyn Cooper notes, for instance, "the Anancy mentality" in the attitude of the higgler personae in Bennett's "South Parade Peddler" and "Candy Seller," whereby their monologues "counterpoint the open cajoling of the customer with sotto voce invective." ${ }^{77}$ Cooper also extends the Anancy tradition in applying a feminist sensibility to the persona, linking the spider to Jamaican women's ability to survive under patriarchy:

the proverbial cunning of the Jamaican woman is one of the manifestations of the morally ambiguous craftiness of Anansi, the Akan hero, transmuted in Jamaican folklore into Bre Nansi, the archetypal trickster. ${ }^{78}$

Like Anancy stories, duppy (meaning ghost or spirit) narratives reveal continuity with Jamaica's African past, in this case through the exploration of supernatural elements. Although it is difficult to pinpoint a definitive source of the term 'duppy', MacEdward Leach notes that the word is found in many West African languages and is tied to the cultural belief in the spirit of dead ancestors who are believed to hover around villages, protecting people and watching to see that tribal laws are well kept. ${ }^{79}$ Looking specifically at the Ashanti peoples, Ronnie Leavitt points to their beliefs in 'saman' (ghosts taking visible form) and 'sasa' (ghosts as invisible powers) as evidence of the importance of spirits in Africa-centred cultures. ${ }^{80}$ Clearly, then, the concept of the duppy in Jamaica is tied to this African belief in the unseen world. Duppies take a wide variety of forms, including the rolling calf and the three-footed horse, ${ }^{81}$ examples of the malevolent forms spirits are sometimes believed to take. In contrast to the "drab colorless ghosts that float around in European lore, Jamaican duppies take on many interesting and different forms and personalities." ${ }^{\prime 2}$

\footnotetext{
77 Cooper, Noises in the Blood, 61.

${ }^{78}$ Noises in the Blood, 46.

${ }^{79}$ MacEdward Leach, “Jamaican Duppy Lore," Journal of American Folklore 74/293 (July-September 1961): 207 .

${ }^{80}$ Ronnie Linda Leavitt, Disability and Rehabilitation in Rural Jamaica: An Ethnographic Study (Rutherford NJ: Fairleigh Dickinson UP, 1992): 67.

${ }^{81}$ The rolling calf is a dangerous duppy who goes around spitting fire and making a hideous noise with a clanking chain. The three-footed horse, an evil spirit in the form of a horse with a one foreleg and two hind legs, is said to haunt the countryside during the night.

${ }^{82}$ Dance, Folklore from Contemporary Jamaicans, 35.
} 
In "Duppy Market," Bennett underscores belief in the supernatural, whereby the poem is demonstrating the connection of the duppy figure to Jamaican culture via the spiritual world which helps to locate indigenous life in Jamaica:

Whe dat yu seh? Yuh head a-raise?

Kibba [cover] yuh mout deh, gal

Train yuh yeye, see one long white-man

Side-a Miss Mattie stall!

But a weh white-man dah do een yah

Dis hour a de nite?

Dat-deh noh mus duppy, Missis?

Me dah pray fi mahnin light! ${ }^{8_{3}}$

Bennett's poem is a good example of how the duppy presence of oral literature was integrated into Jamaica's literary culture, continuing to inform Jamaican cultural production up until the present time. ${ }^{84}$

One finds that the literature of African diasporic communities, whether in the Caribbean, North America or elsewhere, reflects a continuing dialogue between Africa's oral traditions and the New World's European-influenced literary models. The result, according to Brathwaite, is a culture that is "not 'pure Africa,' but an adaptation carried out mainly in terms of African traditions [... and] a literature of local authenticity. ${ }^{1{ }^{85}}$ Brathwaite's comment supports the notion of African continuity in the cultural expressions of Afro-Caribbean people, while also drawing on anti-colonial understandings to recognize the locality and historical underpinnings of these expressions. I believe this inclusive approach provides a more valuable framework for reading Caribbean literature than academic discourse, which often reinforces a fragmentary understanding of African diaspora cultural expression and identity.

It is not surprising that many early and contemporary African Caribbean authors identify storytelling and oral culture as the impetus for their writing careers. Recalling her childhood, Bennett recounts time spent swapping "stories about Anancy, the 'trickify' little spider man who speaks with a lisp and

\footnotetext{
${ }^{83}$ Bennett, Selected Poems, 35, Jamaica Labrish, 194.

${ }^{84}$ See, for instance, Bob Marley's popular hit song "Duppy Conquerer" and Ernie Smith's reggae song "Duppy or Gunman."

${ }^{85}$ Brathwaite, “The African Presence in Caribbean Literature," 255.
} 
lives by wits [...] both comic and sinister, both hero and villain of Jamaican folk stories. ${ }^{n 86}$ The contemporary Canadian poet and historian Afua Cooper also mentions storytelling as having played a significant role in her childhood and subsequent desire to write; she recalls older relatives regularly sharing riddles and duppy stories. ${ }^{87}$

In addition to their communitarian value as entertainment, folk stories and work songs were also "used to inculcate the social and moral values of the society in general or of a particular group. ${ }^{188}$ In the song "Go Way Mandah," for example, a young woman is admonished for being too greedy:

Go way Mandah, go way

Go way Mandah, go you way

Go way Mandah go way

Say you get you pants and boots Mandah

Go way Mandah, go way

Gwan Mandah, go you way. ${ }^{89}$

Such a song, doubtless arising out of a male work-context, can hardly be said to be engaging socially and morally in a transformative spirit; rather, it reinforces the patriarchal reduction of women to vanity.

Jamaican proverbs and sayings often contain references to the folklore characters found in well-known stories, as in popular proverbial expressions such as "Duppy know who fi frighten," and "Man nuh dead nuh call dem duppy." Jamaican work songs also included explicit references to duppies. In the following, the listener is advised thus:

An' you ever hear de duppy laugh

An' you ever hear de duppy laugh

You fe go dung a river side

Sunday mornin' time

Woman duppy laugh ha, ha, ha

An' de man duppy laugh he, heh, heh. ${ }^{90}$

\footnotetext{
${ }^{86}$ Louise Bennett, "Introduction" to Julie Pearn, Poetry in the Caribbean (London: Hodder \& Stoughton, 1985): iii.

${ }^{87}$ Personal communication.

${ }^{88}$ Lewin, Forty Folk Songs ofJamaica, 67.

${ }^{89}$ Lewin, Forty Folk Songs ofJamaica, 68.
} 
Oral practices in Jamaica thus significantly borrowed from and influenced each other. As Levine observes,

The oral inventiveness of good storytellers, who appear to have been relatively common in Black culture, was a source of delight and stimulation to their audiences. Their narratives were interlarded with chants, mimicry, rhymes, and songs. ${ }^{91}$

Not surprisingly, in drawing on folk culture, storytellers and writers often turned to Patwa as the primary language for transmitting their narratives. This use of Jamaican creole conveys the rhythmic sounds and cadences of Jamaican culture and its everyday conversation. Vernacular language likewise plays an integral role in defining the identity of literary characters. It is also important to note that, in addition to language, physical movement was central to storytelling. As Geneva Smitherman and other linguists stress, both body movement and paralinguistic (vocal) approaches were seen as vital in the conveying of stories. If a story is about an animal, for instance, the storyteller takes the form of the animal and "takes on all the animal's characteristics in the narration of events." ${ }^{92}$ This includes the voice, gestures, and postures of the animals or the mythical persons involved in the story.

\section{Healing the Spiritual Damage}

African-Jamaicans have a long tradition of drawing on cultural memory through the use of various oral artforms, which gave them a framework for remembering and re-making indigenous knowledge. Oral folk culture also played a role in healing the spiritual damage of slavery and colonialism by preserving stories which had otherwise been overlooked or distorted through the colonial process. In this context, a retelling of past memories and present narratives be-

\footnotetext{
9o "If You Want to Hear Duppy Laugh," in Jekyll, Jamaican Song and Story, 70. Jekyll identifies this as a digging song.

${ }^{91}$ Levine, Black Culture and Black Consciousness, 88.

${ }^{22}$ Geneva Smitherman, “'The Forms of Things Unknown': Black Modes of Discourse,” in Smitherman, Talkin and Testifyin: The Language of Black America (Boston M A: Houghton Mifflin, 1977): 149 .
} 
came a channel through which resistance could emerge. ${ }^{93}$ The preservation of African storytelling offered a means of creating alternative viewpoints to the dominant narratives propagated by colonial forces. As such, orality served as an 'informal' literature capturing the voices and culture of African-Jamaicans. These imperatives can be seen in the written literature that would later emerge. As Edward Baugh notes,

Anti-colonialism, the necessity for Caribbean self-definition, protest against social ills deriving from considerations of class, colour, and economic status, assertion of dignity and beauty of the Black person, willingness to take poetic nurture from local cultural roots - these were some of the themes that brought a new immediacy to Caribbean literature..$^{94}$

African-Jamaican writers created a "living transformation of a past in new artistic forms, ${ }^{95}$ as will be further illustrated in the following chapters, which explore the ways in which Jamaican literature drew its inspiration from the long oral tradition embedded in African-Jamaican folk expression. Unlike the poets of the Négritude movement who sought to recapture the vernacular traditions of continental Africa, black Jamaican writers of the anglophone Caribbean (as well as their peers across the Caribbean), while influenced by their West African roots, sought material and expression within their local cultures. In doing so, they were later able to transform specific oral, musical, and folk forms into a uniquely Jamaican literary model; a model that would sit comfortably, and autonomously, alongside dominant European literatures.

${ }_{93}$ Andrew Lattas, Cultures of Secrecy: Reinventing Race in Bush Kaliai Cargo Cults (New Directions in Anthropological Writing; Madison: U of Wisconsin P, 1998): 20.

${ }^{94}$ Edward Baugh, "Poetry (The Caribbean)," in The Routledge Encyclopedia of Post Colonial Literature, ed. Eugene Benson \& Leonard W. Conolly (New York: Routledge): 1244.

${ }^{95}$ Cartey, Black Images, 24. 


\section{2 \\ - The African-Jamaican Aesthetic, Pan-Africanism, and Decolonization in Early Jamaican Literature -}

We must encourage our own black authors who have character, who are loyal to their race, who feel proud to be black and in every way let them feel that we appreciate their efforts to advance our race through healthy and decent literature.

N HIS boOk NatURAL MYsticIsm, Kwame Dawes faults Jamaican literature for its failure to offer a sense of self and adequately reflect the nation's socio-political and artistic landscapes. ${ }^{2}$ In particular, Dawes notes that while early Caribbean literature expressed some anti-colonial sentiment, overall it remained conservative and colonial in form. By contrast, he argues, Jamaican reggae music offered a holistic and empowering picture of Jamaican society, and a path to Jamaican selfhood. It was reggae music, not literature, that served to define the Jamaica in which Dawes came of age. There are some points on which I concur with Dawes. Certainly reggae has been a powerful force for representing the narratives of black working-class Jamaicans, articulating themes of African liberation, and, via its Rastafari ethos, capturing the struggle against European domination. Additionally, I agree with him when he writes that the study of the reggae aesthetic provides a useful lens through which to understand Jamaican indigenous knowledges and examine the

\footnotetext{
${ }^{1}$ Marcus Garvey, Philosophy and Opinions of Marcus Garvey, ed. Amy Jacques Garvey (New York: Atheneum, 1982): 140.

${ }^{2}$ Kwame Dawes, Natural Mysticism: Towards a New Reggae Aesthetics (Leeds: Peepal Tree, 1999): 41 .
}

(C) LISA TOMLINSON, 2017 | DOI 10.1163/9789004342330_004

This is an open access chapter distributed under the terms of the CC BY-NC-ND 4.0 license. 
cultural, political, and social development of the country. Having said that, I also believe there are some significant gaps in Dawes' thesis. Specifically, I find that his pronouncements overlook the presence of a clear pan-African sensibility that existed in some of Jamaica's literary works as early as the beginning of the twentieth century. Many early writings offer alternative and empowering narratives and, in fact, served as a catalyst for the reggae artists who later emerged and had such a profound impact on Dawes. This chapter introduces some of these early Jamaican writers, including Claude McKay and Una Marson, who integrated pan-African and anti-colonial sensibilities in their work as a way of inspiring activism and insisting on the rights of African-Jamaican people to define culture on their own terms.

Commenting on pan-Africanism's long history, S.K.B. Asante writes:

throughout the period of the Italo-Ethiopian conflict, pan-Africanism became a rallying slogan, the springboard, the ideological vehicle for common efforts of exiled Africans and West Indians to advance the cause of Africa and Africans. $^{3}$

Looking more particularly at the Caribbean diasporic condition, Ann Snaith notes that "only in the 1920 s and 30 s, with the rise of pan-Africanism and the prominence of Black intellectuals in London, did 'West Indian' emerge as a collective black identity as opposed to a single island consciousness." ${ }^{n 4}$ With these

${ }^{3}$ S.K.B. Asante, Pan African Protest: West Africa and the Italo-Ethiopia Crisis 1934-1941 (London: Longman, 1977): 201.

${ }^{4}$ Anna Snaith, "'Little Brown Girl' in a 'White, White City': Una Marson and London," Tulsa Studies in Women's Literature 27.1 (Spring 2008): 99. While I am aware of the pluralism that exists within Caribbean society, it is important to recognize the periodization in Snaith's comment. Caribbean history is marked largely by the transatlantic slave trade (the Middle Passage). This statement is not to ignore the genocide committed on the American First Nations, Asian indentureship, or the arrival of other ethnic groups to the Caribbean. However, in an attempt to gain cultural sovereignty from European impositions, black intellectuals and cultural activists alike used pan-Africanism as a vehicle to gain black cultural autonomty, whereby it should be kept in mind that some other ethnic groups imported into the region (Indian indentured workers, in particular) were permitted to retain their cultural identity and a shared history largely without consequences. It was through protest and activism (integrating an anti-colonial framework) that pan-Africanism used its politics to revise and galvanize a poetic form emerging from the local cultural roots of enslaved Africans. Many of these themes brought new immediacy to Caribbean literature. For further discussion of this topic, see the "Appendix: From Toussaint 
reflections in mind, this section seeks to foreground African-Jamaican knowledges and their expression as well as the influence of pan-Africanism in Jamaican literature. Here, the life and works of Claude McKay and Una Marson serve as compelling examples of writers who, despite working from diasporic locations, retained, reflected, and celebrated an African-Jamaican aesthetic. Both writers were once often dismissed in studies of vernacular Jamaican literature on the basis of the view that their works, with few exceptions, ${ }^{5}$ mimic European literary style; ${ }^{6}$ rarely have they been considered seminal to the Jamaican literary tradition. Yet despite their use of Western canonical styles, a strong case can be made that their early writings gave voice to the black working-class in Jamaica. McKay and Marson also serve as examples of authors who began their writing careers in Jamaica but later moved to diasporic locations. Finally, both writers were witness to, and participated in, international cultural movements of black consciousness and Africaneity such as Garveyism, the Harlem Renaissance, and pan-Africanism. McKay's and, later, Marson's efforts to craft a body of literature in a colonial context created a grounding from which later African Caribbean artists could emerge to continue the cultural memory of folk and local knowledges and to create a shared language of the Jamaican diaspora.

\section{Claude McKay: The People's Poet}

The anti-colonial theorist Frantz Fanon recognized that, in the movement from colonialism to independence, as the inspiration of revolt and self-identity emerged, the need arose for new forms of cultural expression to give voice to this new consciousness. He noted that, since colonialism suffocates not only local identities but also indigenous cultures, such an artistic renaissance must

\footnotetext{
L'Ouverture to Fidel Castro," in James, The Black Jacobins: Toussaint L'Ouverture and the San Domingo Revolution (1938; New York: Vintage, rev. ed. 1963): 391-418.

${ }^{5}$ These exceptions are of great significance, evidenced as they are in the earliest poetry of McKay and intermittently throughout Marson's oeuvre, as I discuss in detail below..

${ }^{6}$ Hodges, Soon Come: Jamaican Spirituality, Jamaican Poetics, 114; Alison Donnell, "Contradictory (W)omens?: Gender Consciousness in the Poetry of Una Marson" (1996), in The Routledge Reader in Caribbean Literature, ed. Alison Donnell \& Sarah Lawson Welsh (London: Routledge, 1996): 187 .
} 
often be preceded by deep research into the pre-existing local cultures. ${ }^{7}$ Claude McKay's work can be situated in just such an effort, serving as a template for a literature of decolonization. While McKay's poetic and narrative forms cleaved closer to Anglo-American literary traditions, his work nevertheless provided a vital platform for the introduction of local lives and settings from Jamaica to Jamaican and international readers. In this, his work represented a significant departure from the British narratives of the Caribbean that dominated the colonial period. Literary works such as E. Dodds's Maroon Medicine (1905) and W.A. Campbell's Marguerite: A Story of the Earthquake (1907), for example, offered stereotypical reflections of the Caribbean. The assumption behind these early narratives was that Caribbean people had no history of their own and had to rely on British literary models and a eurocentric view of the world to represent their cultural environments. McKay's writings contested this assumption by offering an intimate insider's look at the life of local African-Jamaicans. McKay, not least out of political conviction, was clearly dedicated to creating a literature of decolonization. Indeed, his choice of characters and themes, along with the presence of Africa-centred religion, Patwa, and other folk traditions, is evidence of his efforts to lift the weight of colonialism from Jamaican shoulders, an endeavor Fanon described as essential to the anti-colonial project (in his case, in North Africa and implicitly in his Martinican homeland).

McKay's Banana Bottom (1933) serves as an example of these efforts. In this novel, the African-Jamaican protagonist, Bita Plant, rejects a European lifestyle in favour of a Jamaican one - a revolutionary decision, given the time. While Bita is offered European grooming by the Craigs, a white British family who adopt her, she is more interested in regaining her self-identity and connecting with her local Jamaican community. The Craigs consider Bita their great experiment, an experiment that will allow her to blossom into a "noble" and "polished" British subject, thus saving her from the disadvantages of being black, poor and "primitive." Indeed, their hope is that by the end of their interventions she will "be English trained and appearing in everything but the colour of her skin." ${ }^{8}$ Bita, however, has other plans. She cuts her ties with the

\footnotetext{
${ }^{7}$ Frantz Fanon, The Wretched of the Earth, 210-23.

${ }^{8}$ Claude McKay, Banana Bottom (1933; New York: Harcourt Brace Jovanich, 1961): 31.
} 
British university the Craigs have enrolled her a, and marries a poor rural peasant, Jubban, ${ }^{9}$ instead of the man chosen by her foster parents.

Bita's rebellion against colonial expectations challenges the socio-cultural and political status quo in Jamaica. This challenge is a response to the colonial brainwashing in the region, applied particularly effectively via Caribbean educational institutions and mainstream religion. As the Cape Verdean theorist and activist Amilcar Cabral points out,

it happens that a considerable part of the population, notably the urban or peasant petite bourgeoisie, assimilates the colonizers' mentality, considers itself culturally superior to its own people and ignores or looks down upon their cultural values. ${ }^{10}$

In Bita, McKay presents Jamaicans with an alternative: a quest for self-actualization based on local culture and African identity. Bita's journey represents the possibility of (re)searching and (re)connecting with the folk cultures of black Jamaicans as a path to indigenous self-identity. Indeed, it is a journey through which Bita "discovers the autonomy by which she can be true to herself and her African-Jamaican community, perpetually." Bita's questioning, and then rejecting, of the colonial process is captured in a scene at the end of Chapter 22:

The profession of religion left her indifferent. She was sceptical about it - this religion that had been imposed upon and planted in her young mind. She became contemptuous of everything - the plan of her education and the way of existence at the mission, and her eye wondering to the photograph of her English college over her bed, she suddenly took and ripped it from its frame, tore the thing up and trampled the pieces under the feet.... ${ }^{12}$

${ }^{9}$ McKay's choice of the name Jubban is noteworthy, as it is also the name of a well-known healing plant from the pantheon of African-Jamaican folk medicine; Carolyn Cooper, "'Something Ancestral Recaptured': Spirit Possession as Trope in Selected Feminist Fictions of the African Diaspora," in Motherlands: Black Women's Writing from the Africa, the Caribbean, and South Asia, ed. Susheila Nasta (New Brunswick NJ: Rutgers UP , 1992): 68.

${ }_{10}$ Amilcar Cabral, "National Liberation and Culture," in Return to the Source: Selected Speeches of Amilcar Cabral (New York: Monthly Review Press, 1973): 45 .

${ }^{11}$ David Nicholls, "The Folk as Alternative Modernity: Claude McKay's Banana Bottom and the Romance of Nature," Journal of Modern Literature 23.1 (Fall 1999): 79.

${ }_{12}$ McKay, Banana Bottom, 212. 
Bita's rejection of an uncritical adoption of the values of the mainstream churches in Jamaica suggests the need for an alternative response, one that expresses respect and appreciation for African-centred religious practices. For instance, we find Squire Gensir, one of the characters, reminding Bita that while obeah is seen as primitive in the eyes of Europeans, it is, in fact, "a part of your folklore, like Anancy tales and your digging jammas. And your folklore is the spiritual link between you and your ancestral origin. ${ }^{13}$ Squire also voices his disapproval of missionaries for being "the wreck and ruin of folk art through the world. ${ }^{14}$ Squire's articulations suggest that embracing indigenous religious practices represent a significant path toward liberation. Not all scholars have assumed this same reading of Squire, however. Tyrone Tillery asserts that Squire is in fact a representation of the British folklorist Walter Jekyll, who mentored McKay in his early career and encouraged him to write his poems using Jamaican creole. ${ }^{15}$ I find this assertion troubling, as it assumes and reinscribes the notion that black (artists) are in need of, and indebted to, white patronage in order to claim freedom.

Earl Lovelace asserts the same belief, explaining that obeah provided Jamaicans with a grounding from which to survive the trauma of slavery and colonialism. Obeah, he observes,

was the means with which the sense of Africa had a philosophical expression. It was a means through which Africa was expressed in terms of potency, in terms of a philosophy that could be pitted against the European. It was a worldview of Africa. It was another form, another way beyond the logic of science; obeah was the mystery of science. ${ }^{16}$

McKay's use of Gensir Squire to insert obeah into Banana Bottom can thus be read as a radical literary act of decolonization that simultaneously de-centred the European world-view and opened up a spiritual link to West Africa. David Nicholls extends this reading to suggest that the novel acts as a critique of European modernity:

\footnotetext{
${ }^{13}$ McKay, Banana Bottom, 125.

${ }^{14}$ Banana Bottom, 126.

${ }^{15}$ Tyrone Tillery, Claude McKay: A Black Poet's Struggle for Identity (Amherst: U of Massachusetts P, 1992): 131-32.

${ }^{16}$ Earl Lovelace, "Working Obeah," in Lovelace, Growing in the Dark (Selected Essays), ed. Funso Aiyejina (Trinidad: Lexicon, 2003): 218-19.
} 
McKay argues for the rejection of colonial cultural ideology - most notably, Christianity and the return to the folk, as a route to autonomy for Afro-Jamaican peasants.

He goes on to posit that this autonomy

is imagined not only as an alternative to the modernity of the colonial mission, but also as a form of resistance to the vagaries of the global commodities market and to the incursions of low-wage immigrant labor. ${ }^{17}$

Despite this evidence of McKay's efforts to de-centre Europeanness, Banana Bottom has been criticized for its ending, which is described as utopic and romanticized. ${ }^{18}$ This critique is a response to Mckay's seeming efforts to enact a past connection to an African origin by having Bita gain affiliation to the Jamaican working-class via folk culture. This interpretation, ironically, is a view through a eurocentric lens. The Africanist Josaphat Kubayanda defines eurocentrism as the holding of "an essentially colonial concept of the world," a totalizing European view of experience which "suggests that standards of interpretation should come exclusively from Europe." ${ }^{\prime 19}$ To elucidate this, he cites Jean Claude Michel's analysis of Les écrivains noire et le surréalism (The Black Surrealist), which argues that Aimé Césaire's poems are surrealistic - a view that, Kubayanda suggests, eurocentrically overlooks or downplays the "issues of identity, revolt and linguistic 'violence'" that Césaire's poetry so clearly expresses. ${ }^{20}$ In this way, analyses like Michel's "deny black writing the ability to portray the experience from a Black standpoint; it also narrows the reading experience in general." ${ }^{21}$ Amiri Baraka echoes Kubayanda's concerns in his work

${ }^{17}$ Nicholls, "The Folk as Alternative Modernity," 79.

${ }^{18}$ Michael Gilkes, The West Indian Novel and Its Background (Boston M A: Twayne, 1986): 14; Leota S. Lawrence, "Three West Indian Heroines: An Analysis," College Language Association Journal 21.2 (December 1977): 250.

19 Josaphat Kubayanda, The Poet's Africa: Africanness in the Poetry of Nicolás Guillén and Aimé Césaire (Westport CT: Greenwood, 1990): 7.

${ }^{20}$ Kubayanda, The Poet's Africa, 7 .

${ }^{21}$ The Poet's Africa, 7. In fact, Césaire makes the same argument himself when he explains: "If I apply surrealism to my particular situation, I can call up unconscious forces. For me this is the call to Africa. I say to myself that it is true that superficially we are French; we are marked by French Traditions. We have been marked by Cartesianism and by French Rhetorical models, but if you break all that and if you go beneath this you will find an essentially Black man"; Maro Riofrancos, 
Blues People, in which he proposes an alternative modernity to Euro-American modernism, thus enabling a new reading of African-American cultural expression. Baraka notes, for example, that where Euro-American modernity tends to denote and rely on linear forms, black modernity showcases the possibilities of repetition as a structure. Nadi Edwards extends this thinking about black modernity to warn against interpreting roots reggae texts about history and slavery as simply "a form of self-indulgent wallowing in the condition of victimhood and refusal to face the realities of modernity by escaping nostalgia and fantasizing about Africa"; ${ }^{22}$ instead, roots reggae must be understood and taken up as a legitimate form of black modernity in its own right. Edward Kamau Brathwaite provides similar insights; using Paule Marshall's novel The Chosen Place, the Timeless People, he demonstrates the ways in which the use of African elements are an important acknowledgement not only of an African past but also of a desire to practice what he calls reconnection. ${ }^{23}$ With these understandings in mind, McKay's 'romantic' ending, rather than being eurocentrically read as illusory and idealized, may become a return to her past replete with texture and meaning. Working with the notion of reconnection results in a very different reading of McKay's conclusion, in which Bita's return to her historical past is not an idealized venture but an expression of reconnection to her ancestral past. Indeed, Bita's connection with folk culture, as Squire Gensir reminds her, is a crucial link in the path back to a cultural home. In this way, Bita's return to her past disrupts the linearity and colonialism inherent in European modernism. Banana Bottom

argues for the authenticity of peasant culture so as to advance a secondary argument for Afro-Jamaicans to participate in the peasant appropriation of economic capital. ${ }^{24}$

As Kwame Dawes further reminds us, "the past is regarded as a tool with which to identify the conditions of the present." ${ }^{25}$

\footnotetext{
"An Interview with Aimé Césaire," in Aimé Césaire, Discourse on Colonialism (New York: Monthly Review Press, 1972): 71.

${ }^{22}$ Nadi Edwards, "States of Emergency: Reggae Representations of the Jamaican Nation State," Social and Economic Studies 47.1 (March 1998): 31 .

${ }^{23}$ Brathwaite, "The African Presence in Caribbean Literature," 255-57.

${ }^{24}$ Nicholls, "The Folk as Alternative Modernity," 79

${ }^{25}$ Dawes, Natural Mysticism, 56.
} 
McKay's poetry, too, presents rich textual material for examination. His earlier volumes, such as Constab Ballads (1912) and Songs ofJamaica (1912), are, subversively for their time, written entirely in Jamaican Patwa. This question of language is critical to any discussion of McKay's poetry. As mentioned above, it is widely believed that McKay was actually encouraged to use Patwa in his writing by Walter Jekyll, a white British expatriate and folklorist who would prove to be an important figure both as a supporter of his early literary efforts and as a mentor. Jekyll's relation to McKay has, not surprisingly, been read by some critics as problematic. Lee Jenkins, for example, argues that Jekyll's interventions parallel those of white abolitionist interjections in or shaping of slave narratives. ${ }^{26}$ Jenkins' comments remind me of my own initial uncertainty about whether McKay's earlier poems could serve as strong examples of local and indigenous knowledges. However, closer analysis of his work allowed me to conclude that McKay's vernacular poems were indeed uniquely grounded in the linguistic, cultural, and domestic specificity of the Jamaican environment. While Jekyll may have initially planted the seed of writing in Patwa - he was certainly fundamental to the publication of Songs of Jamaica - by the time of McKay's next volume of poems in the vernacular (Constab Ballads) he was working on his own. In the end, Jenkins herself concedes that McKay's "linguistic forms of Creole underscore the local specificity and African origins of that vernacular. ${ }^{27}$ McKay's use of Patwa is a deliberate effort to express an indigenous voice beyond the constraints of the British literary canon.

McKay's use of the vernacular ${ }^{28}$ as an expression of reclamation and resistance is by no means unique. Many writers have chosen to distance themselves from hegemonic forms of dominant languages because of their inability to speak to, and for, local concerns. Dante Alighieri, for example, employed the Tuscan dialect of Italian in his writing as a replacement for Latin because the former was a more accessible means of communication among the local population. Jekyll himself draws this parallel to Italian in his preface to McKay's Songs ofJamaica, in which he argues that "what Italian is to Latin that in regard

\footnotetext{
${ }^{26}$ Lee M. Jenkins, The Language of Caribbean Poetry: Boundaries of Expression (Gainesville: U P of Florida, 2004): 176.

${ }^{27}$ Jenkins, The Language of Caribbean Poetry: Boundaries of Expression, 20.

${ }^{28}$ While I understand the use of vernacular culture to include folk culture (proverbs, riddles, religion etc.), I am referring here to Patwa or Jamaican creole.
} 
to English is the Negro variant thereof. ${ }^{29}$ Speaking in a more directly colonial context, the Kenyan writer Ngũgĩ wa Thiong'o has the following to say about his effort - belated, after years of writing in English - to legitimize his native language through literary means:

I still hold that our Kenyan culture must be totally free from foreign domination in at least the following area: our national languages. [...] At present, these national languages have been relegated to the dustbins. Instead, English, French, German are given the pride in our schools. By [being] so encouraged to hate their national languages, the children are being encouraged to hate or despise the begetters of these languages, i.e. their peasant parents. And they are encouraged to admire the begetters of English, German i.e.; foreigners. ${ }^{30}$

Ngũgĩ's comments clearly underscore the difficulties African and black diasporic writers face in creating independent discourses. ${ }^{31}$ Given these challenges, I propose that anti-colonial writers often see themselves as tasked with rewriting canons and reclaiming a literary and national voice as an important pathway to cultural expression and sovereignty. Merle Hodge reflects on this task in a Caribbean context, contesting the contempt held for Caribbean creoles and making a passionate plea that "we need Creole, we cannot function without Creole, for our deepest thought processes are bound up in the structure of Creole. ${ }^{\prime 32}$ The Canadian-Caribbean dub poet and playwright Ahdri Zhina Mandiela echoes Hodge's call in her reflection that she uses creole in her poems because it represents "more precise symbols, hence crisper, more descriptive images." ${ }^{\text {33 }}$ It should be noted, however, that this is a marked difference for some Caribbean writers - for instance, Aimé Césaire, who, despite encouragement from his mentor to employ Martinican Kreyòl in his literary work, chose

${ }^{29}$ Jekyll, Jamaican Song and Story, 5.

${ }^{30}$ Ngugi wa Thiong'o Speaks: Interviews with a Kenyan Writer, ed. Reinhard Sander \& Bernth Lindfors (Oxford: James Currey \& Nairobi: East African Educational, 2006): 94.

${ }^{31}$ Kubayanda, The Poet's Africa, 71.

${ }^{32}$ Merle Hodge, "Challenges of the Struggle for Sovereignty: Changing the World versus Writing Stories," in Caribbean Women Writers: Essays from the First International Conference, ed. Selwyn R. Cudjoe (Wellesley MA: Calaloux, 1990): 204.

${ }^{33}$ Makeda Silvera, "An Interview with Ahdri Zhina Mandiela: The True Rhythm of the Language," in The Other Woman: Women of Colour in Contemporary Canadian Literature, ed. Makeda Silvera (Toronto: Sister Vision, 1995): 81. 
French, declaring, in an interview: "for me writing is linked to French and not Creole. ${ }^{34}$ McKay (like Caribbean writers to follow) did not doubt the capacity of his native language and saw it as a viable means to voice the concerns of the African-Jamaican working class.

Many critics recognize McKay's use of Patwa as belonging to this tradition of anti-colonial writing. Alison Donnell and Sarah Lawson, for example, posit that Songs of Jamaica and Constab Ballads should be recognized as instrumental precursors of the work of Una Marson, Louise Bennett, and other significant Jamaican writers. ${ }^{35}$ Even Brathwaite, who takes some issue with McKay's work, concludes that his early poems represent an important stepping-stone for creole literature.$^{36}$ Indeed, in an age in which literature was routinely criticized for being out of touch with, and inaccessible to, regular Caribbean folks, McKay provided an alternative:

ordinary Jamaicans, especially the peasants, loved McKay's poems and he loved the fact they recognized themselves, their struggles and their aspirations in his work. ${ }^{37}$

In one letter in particular, McKay vividly recalls:

I remember when my first poem came out, the market women stopped me by the roadside and asked me to read them. Those were the happiest readings I ever gave..$^{38}$

Given these ties, I propose that McKay's connections to marginalized black Jamaicans are similar to those of later figures such as the popular dancehall

34 "Pour moi, l'écriture est liée au français, et pas au créole, c'est tout," in "Entretien avec Aimé Césaire, Paris, 1975, à l'occasion de la réédition de Tropiques," in Jacqueline Leiner, Aimé Césaire: le terreau primordial (Études littéraires françaises; Tübingen: Gunter Narr, 1993): 118; quoted in Shireen K. Lewis, "The Créolité Movement: Reconfiguring Identity in the Caribbean in the Late Twentieth Century," in Lewis, Race, Culture, and Identity: Francophone West African and Caribbean Literature and Theory from Négritude to Créolité (Lanham MD \& London: Lexington, 2006): 91.

35 Alison Donnell \& Sarah Lawson Welsh, "Introduction" to The Routledge Reader in Caribbean Literature, ed. Donnell \& Welsh (London: Routledge, 1996): 37.

${ }^{36}$ Brathwaite, History of the Voice, 20.

${ }^{37}$ Winston James, "Becoming the People's Poet: Claude McKay's Jamaican Years, 1889-1912," SmallAxe 13/7.1 (March 2003): 44 .

${ }^{38}$ McKay, quoted in James, "Becoming the People's Poet," 29. 
deejay Bounty Killa, who has been called "de people's government" for his role in speaking out against the unjust treatment of Jamaica's black urban poor.

In Constab Ballads and Songs of Jamaica, the use of Patwa allows McKay to insert the perspective of the African-Jamaican working poor, at a time when these voices were absent from Jamaican literature. In these poems, the narrative voices focus on the everyday life experiences of the rural and urban working class under British rule and challenge the perceived authority of the middle and upper classes. This function of language in McKay's poetry is reflected in Winston James's comment: "racism, color, class, justice and injustice, oppression and revolt are all given expression. ${ }^{39}$ Referring in particular to the poem "Quashie to Buccra," James notes that the title itself is instructive, pointing to "antipodes of Jamaica's social world: the Black Country bumpkin, the peasant, the subaltern, and the symbol of power, superordination, the oppressor, the white man.. ${ }^{40}$ The text conveys the daily toil and sweat the "nygur man" (that is, black labourers) must spend in the field:

De sun hot when fire ketch a town;

shade-tree look tempin', et we caan' lie down

Aldough we wouldn't eben ef we could, causen we job must finish soon an' good. ${ }^{41}$

Despite these conditions of oppression, the peasant persona uses his own language to protest his lot and insist on higher wages: 'You tas'e petater an' you say it sweet, / But you no know how hard we wuk fe it." The white overseer or Buccra is then forced to bargain for a lower price. He may want "a basketful fe quattiewut" (a quarter of a sixpence), but Quashie vocally objects to the trivialization of his labour and "race": "cause you no know how 'tiff de bush fe cut' / De cowitch [itchy vine] under which we hab fe' toop... / is killin' somet'ing for a naygur man. ${ }^{\prime 42}$ McKay's use of the vernacular in "Quashie to Buccra" draws on and echoes the early work songs of African-Jamaican labourers and allows the persona to comment on the harsh social conditions of toiling on the land.

\footnotetext{
${ }^{39}$ Winston James, A Fierce Hatred of Injustice: Claude McKay's Jamaica and His Poetry of Rebellion (London: Verso, 2000): 56.

${ }^{40}$ James, A Fierce Hatred of Injustice, 59.

${ }^{41}$ Claude McKay, Complete Poems, ed. \& annotated by William J. Maxwell (Urbana: U of Illinois $\mathrm{P}, 2004): 19$.

${ }^{42}$ McKay, Complete Poems, 19.
} 
However, Quashie also challenges the notion that he is only a dehumanized victim, instead claiming pride and dignity in his identity as a worker and reflecting on the joys and rewards of farm labour:

De fiel' pretty? It couldn't less 'an dat, we wuk de bes', an den de lan' is fat; we dig de row dem eben in line,

An' keep it clean - den so it mus' look fine. ${ }^{43}$

While Quashie's name during slavery may have denoted the stereotype of male docility and stupidity, Quashie now challenges those very stereotypes by asserting his agency and citizenship and by demonstrating an acute understanding of the social context in which he operates. His inability (or refusal) to speak a standardized English positions him as the legitimate and rightful voice of the black Jamaican working class, in the same way as McKay's refusal to write in that English legitimizes his role as social critic.

In addition to exploring rural Jamaican experience, McKay's early poems also voice the social realities of the Black urban working class. In the poem "Bobby to the Sneering Lady," for instance, McKay unexpectedly has the constable on duty side with a black servant girl who has been beaten by her white, or "light-skin" middle-class employer. Refusing to arrest the girl, the constable insists: "Our soul's jes like fe you, / If our work does not make us rough / Me won't 'res' you servant-gal / When you've beaten her enough." 4

The officer not only sympathizes with the "servant-gal" but also expresses kinship with her: "fe me own black kin' / I mus' not be too unkind." 45 Here, McKay's use of dialect shading as shared by the officer and the domestic servant demarcates the boundaries of 'race', class, and colour in Jamaican society and challenges the unbridled power of the middle class, whose authority he is, ironically, expected to uphold.

Like Banana Bottom, and linked to his critique of the Jamaican middle classes, McKay's poetry also examines questions of religion and its dual role as both empowering and oppressive. Brathwaite argues that African culture is predominantly based on religion, even going so far as to posit that "it is within

\footnotetext{
43 McKay, Complete Poems, 19.

${ }^{44}$ Claude McKay, Constab Ballads (London: Watts, 1912): 66.

45 McKay, Constab Ballads, 67.
} 
the religious network [that] the entire culture resides." ${ }^{m 6}$ In this connection, Elaine Brown Spencer acknowledges the African diaspora's problematic relationship to Christianity, but she nevertheless asserts the vital role that the black church and spirituality has played in their lives:

Herein lies the paradox: the black Church was able to recognize the liberating and emancipatory aspects of biblical Christianity and use it as an anti-colonial tool, though Christianity was used as a colonial tool by the Europeans who enslaved blacks. ${ }^{47}$

Brathwaite's and Brown Spencer's frameworks insist on the necessary centrality of the black church and spirituality in any discussion of black oppression and anti-colonial resistance. We see just such an example in McKay's injection of black religious spirituality into his textual landscape.

McKay's personae speak of an organic spirituality emerging from the experience of having one's humanity undermined in the context of an oppressive society. The peasant in the poem "Hard Times," for example, both questions God for the suffering he must endure and calls upon Him for sustenance and deliverance:

says I ben'mi knee en pray to Gahd

yet t'ings same as befo....

I won't gib up. I won't stay die,

For all de time is ard;

Although de wul soon en. I'll try

My wutless best as time goes by

an trust on in me Gahd. ${ }^{48}$

Similarly, in "The Apple Woman's Complaint," the narrator is a street vendor crying out to God against police brutality: “O massa Jesus! don't you see / how police is oppressin' we?"49 She, too, articulates a call for divine intervention:

Ah mass Jesus! in yu love

Jes'look do'n from you t'rone above,

\footnotetext{
${ }^{46}$ Brathwaite, "The African Presence in Caribbean Literature," 194.

${ }^{47}$ Elaine A. Brown Spencer, "Spiritual Politics: Politicizing the Black Church Tradition in AntiColonial Praxis," in Anti-Colonialism and Education: The Politics of Resistance, ed. George J. Sefa Dei \& Arlo Kempf, foreword by Molefi Kete Asante (Rotterdam: Sense, 2006): 107.

${ }^{48}$ McKay, Complete Poems, 41-42.

${ }^{49}$ McKay, Constab Ballads, 58.
} 
An' show me how a poo' weak gal

Can lib good life in dis ya wul'... ${ }^{50}$

The personae in both poems question God's power to change their situation, yet they still turn to religion for the hope they need to help them face the challenges of their daily lives, perhaps because they are unable to locate this hope anywhere else. Some critics, Winston James among them, insist that many of McKay's works are, in fact, mere testaments to his atheistic and rationalist beliefs, and his view that the church was a primary factor in the oppression of people of African descent. ${ }^{51}$ While it is true that McKay may personally have seen religion as a disingenuous system which oppressed blacks, his works make it clear that he also recognized the potential of African-Jamaican peasants and urban dwellers to inflect their everyday lives transformatively with spirituality.

McKay is noteworthy, additionally, for the pan-African sensibility in his writing. In the same manner in which Négritudewriters strove to re-imagine the standard French literary canon and articulate a distinctively 'Negro' voice, McKay's poems evoke a parallel black consciousness. Although his commitment to pan-Africanism has been chiefly linked to his time outside of Jamaica, James asserts that it was actually McKay's experience in the Jamaican Constabulary Force that inspired the black consciousness that later revealed itself in his manuscripts. ${ }^{52}$ In discussing pan-Africanism, it is important to note that, in their enthusiasm for Black Nationalism, both McKay and some of his Négritude peers sometimes presented uncritical images of Africa, either as romanticized or as stereotypical. In his poem "Gordon to the Oppressed Natives," McKay uses problematic stereotypes, for example, to depict the continent, relying on such images as "lions in the veins" and "gorillas in the blood," and echoing notions of Africa as primitive. Brathwaite suggests that here McKay is employing what he calls a "rhetorical literature," which is "static, wishful in nature. Although it betrays a significant instinct for Africa, the instinct is based on ignorance and often $[\ldots]$ on received European notions of 'darkest Africa'." ${ }^{53}$

\footnotetext{
${ }^{50}$ McKay, Constab Ballads, 58.

${ }^{51}$ James, A Fierce Hatred of Injustice, 124.

${ }^{52}$ A Fierce Hatred of Injustice, 72.

${ }^{53}$ Brathwaite, "The African Presence in Caribbean Literature," 214.
} 
McKay's later work, however, moves away from such stereotypes. In the sonnet "Outcast," he professes his spiritual oneness with Africa and articulates his yearning for the long-forgotten teachings of the continent:

For the dim regions whence

my fathers came

My spirit, bondage by the body,

longs

words felt, but never heard

my lips would frame

my souls would sing forgotten

jungle songs... ${ }^{54}$

And while McKay's use of the word "jungle" here may give rise to questions about representing Africa as primitive or savage, we see in the poem "Africa" his striving to strike a balance between realism and romanticism; while the first verses pay tribute to the continent's past glories, the later ones end:

... Yet all things were in vain!

Honour and Glory, Arrogance and

Fame!

They went. The darkness.

swallowed thee again.

Thou art the harlot, now thy time is

Done,

Of all the mighty nations of the

Sun. ${ }^{55}$

McKay's reclamation of Africa as a source of aspiration and validation is significant and forged a path for the roots reggae artists and dub poets who would follow decades later and take up the naming of the continent as a site of home, identity, and strength. At the same time that McKay is seeking to reclaim pride in Africa, however, he appears to be struggling with the very stereotypes he is trying to overturn. This would also be true of later reggae artists and dub poets seeking a reconnection to a continent they deeply desire, but which has been located so negatively in colonial narratives that they unwittingly reproduce some aspects of this discourse.

\footnotetext{
${ }^{54}$ McKay, Complete Poems, 173.

${ }_{55}$ McKay, Complete Poems, 169.
} 
McKay's later poems provide a striking study in the re-imagining and radicalization of British forms, such as the sonnet, to express social protest against black oppression within the larger context of the Americas. In "Harlem Dancer," for instance, we come to know the humanity of sex workers in the underground world of the Harlem nightclub:

The wine-flushed, bold eyed boys, and even the girls,

Devoured her with their eager, passionate gaze;

But, looking at her falsely-smiling face

I knew her self was not in that strange place..$^{56}$

But it is McKay's best-known poem, "If We Must Die," that serves as the quintessential example of transforming British literary forms into something new. In it, McKay appropriates the sonnet in order to give voice to the black diasporic experience and to articulate a passionate call for Black Nationalism:

If we must die, let it not be like hogs

Hunted and penned in an inglorious spot,

While round us bark the mad and hungry dogs,

Making their mock at our accursed lot.

If we must die, $\mathrm{O}$ let us nobly die,

So that our precious blood may not be shed

In vain; then even the monsters we defy

Shall be constrained to honor us though dead!

O kinsmen we must meet the common foe!

Though far outnumbered let us show us brave,

And for their thousand blows deal one deathblow!

What though before us lies the open grave?

Like men we'll face the murderous, cowardly pack,

Pressed to the wall, dying, but fighting back! ${ }^{57}$

Such words surely set McKay a place at the table with activists and writers such as Marcus Garvey, C.L.R. James, and Aimé Césaire, all of whom were similarly committed to raising awareness of the struggles of people of African descent around the world and promoting a black folk aesthetic through the project of academic and literary decolonization. As James avows,

\footnotetext{
${ }^{5}$ McKay, Complete Poems, 172.

${ }^{57}$ Claude McKay, Harlem Shadows (New York: Harcourt, Brace, 1923): 177-78.
} 
The respect, beauty and integrity with which black people, especially Jamaican peasantry, are portrayed in these early poems make Song ofJamaica and Constab Ballads founding texts in negritude, even beforethis ideological current had a name. (Some of the themes discussed earlier - color and class, Christianity, the black woman - would emerge as important motifs in the poetry of Négritude especially in the work of Aimé Césaire, Léopold Senghor and Léon Gontran Damas)..$^{8}$

McKay has actually been credited by Césaire for being an important influence on the Négritude movement. ${ }^{59}$ By using the indigenous languages and local cultures of ordinary Jamaicans to shape a uniquely Jamaican aesthetic both in the island and in the USA, he provided an early model of black aesthetics that could be shared with other writers of African descent also seeking to assert creative and political agency.

McKay, therefore, presents a compelling example of how Caribbean indigenous knowledges might have meaning in diasporic understandings of the world. He demonstrates this, for example, in his novels Home to Harlem and Banana Bottom, which I take up further in Chapter 5. Although these works were written outside of Jamaica, indeed after many years of absence from the island, McKay pulls from his African-Jamaican folk roots "to offer careful analysis of the modern global economy and Jamaica's place within it." ${ }^{\prime 60}$

For the purposes of this chapter, I use McKay's poem “The Tropics in New York" to signal the Caribbean immigrant's longing for home. In the poem, this is captured in the yearning for foods from the past: "Bananas ripe and green, and ginger root / Cocoa in pods and alligator pears [... Sat in the window, bringing memories." The poem goes on to lament the deeply felt loss of "old, familiar ways," such that "I turned aside and bowed my head and wept". ${ }^{61}$ These recurring themes of nostalgia are, of course, common in diasporic writing, yet they are often misread as romantic nostalgia rather than a claiming of cultural identity. For McKay, drawing on the memories of the past provides a familiarity that can contest the alienation and marginalization immigrants experience in

\footnotetext{
${ }^{5}$ James, A Fierce Hatred of Injustice, 130.

${ }^{59}$ Aimé Césaire, Discourse on Negritude: Miami 1987 (Fort de France: Conseil général de la Martinique, Bureau de la Communication et des Relations avec la Presse, 2003): 44.

${ }^{60}$ Nicholls, "The Folk as Alternative Modernity," 80.

${ }^{61}$ McKay, Complete Poems, 154.
} 
large isolating cities such as New York. McKay's deep attachment to Jamaica as a place of home and the source of his historical memory is also clear in the poem "My Native Land, My Home," in which the speaker declares with pride that "Jamaica is de nigger's place [...] although dem call me' no-land-race', / I know me home is here." ${ }^{\text {62 }}$ Here the embracing of home is not an act of "the colonial subject keeping his place and knowing it," ${ }^{\prime \prime 3}$ but, rather, an embracing of African-centred culture, place, and identity.

Taking McKay's body of work as a whole, it becomes clear that his is a literary journey of decolonization. He begins his explorations as a Jamaican poet committed to the struggles of everyday Caribbean people and later, following migration to the USA, takes up the cause of justice for African Americans and, more broadly, the transatlantic black migrant (a topic I return to in Chapter 5). McKay's literary style also evolves over time, but always with an interest in radicalizing Western literary forms to encompass and express indigenous resistance to oppression. His early efforts in this regard focus on the use of Jamaican Patwa as a meaningful language of creative expression. Interestingly, this is not a style McKay maintains; his later works do not, in the main, depart from Standard English. Here one might surmise that McKay therefore does not entirely fulfil the aspirations of Dei's anti-colonial literary framework, which calls for the centering of indigenous and local knowledges, including, of course, language. However, it is also true that while McKay's language moves away from Jamaican Patwa, he adopts English, in part, to become part of a wider global dialogue about the transnational black experience. Additionally, the content of his literary works, even those written outside of Jamaica, continued to reflect his enduring attachment to and deep affection for his folk roots and African-Jamaican cultural identity. Indeed, as Wayne Cooper reminds us, "McKay's uniqueness and importance lay in his intense celebration of his rural, specifically black, Jamaican origins." ${ }^{n 4}$ At the same time, McKay's later works also draw on, and converse with, other cultural forms such as jazz and the African-American vernacular to extend his exploration of the black working-class experience. In the final analysis, McKay's literary canon shows a

\footnotetext{
${ }^{62}$ McKay, Complete Poems, 57.

${ }^{63}$ Jenkins, The Language of Caribbean Poetry: Boundaries of Expression, 17.

${ }^{64}$ Wayne Cooper, Claude McKay: Rebel Sojourner in the Harlem Renaissance (New York: Schocken, 1990): 37 .
} 
deep commitment to integrating Jamaican and other black aesthetics as a means of sharing and forwarding an anti-colonial and African-centred vision of the world.

\section{Una Marson: Searching for a Native Voice}

Una Marson continues McKay's literary legacy through the integration in her work of Jamaican Patwa and a deliberate claiming of African-Jamaican folk culture. Like McKay, while Marson uses traditional Western forms, she also makes substantial departures from them, so that the content of her work, and to a great extent her form, are radical in nature. This is especially true given that Marson was exploring the application of an African-Jamaican aesthetic at a time when British influence was still dominant in the shaping of black anglophone Caribbean identity. Interestingly, Marson's own time living in England provided her with new perspectives on blackness, colonialism, and modernism, themes to which she turned in her work. Marson's manuscripts embody an anti-colonial framework because of the ways in which she draws on local knowledges to work against European hegemony and assert an AfricanJamaican identity. Marson's literary efforts were clearly informed by her political activism, which revolved around black pride and emancipatory movements, seen most obviously in her work alongside Haile Selassie to liberate Abyssinia. Not surprisingly, then, her work also incorporates a pan-African sensibility. Marson was also actively involved in the early women's movement, where she sought to vocalize the unique needs of black women, a topic I return to in Chapter 4.

While Marson's first two poetry volumes, Tropic Reveries (1930) and Heights and Depths (1931), were influenced mainly by English Romanticism and were, thus, dismissed by critics as too sentimental, her later poems took a more radical turn. Influenced by the likes of Marcus Garvey and his vision of black nationalism, Marson became a strong proponent of the potential of Jamaican writing to articulate the struggle for decolonization. In her 1937 collection The Moth and the Star, her attempts to overcome mimicry of colonial forms come to the fore. The poems are clearly generated by a pan-African awareness, exploring as they do issues of race, colour, and class discrimination. One of the prevalent themes in the collection, for example, is a candid critique of the as- 
sumed Europeanness in mainstream standards of beauty. Her poems critique the white images of beauty engrained in the psyche of black people and encourage black women to look beyond this and embrace their blackness. "In "Cinema Eyes," the persona comments on the deleterious effects of media on black women's self-image. The poem features a black mother who, having grown "up with cinema mind" that "saw no beauty in black faces," now yearns to protect her daughter from the same whitewashing:

Come, I will let you go [to the cinema]

When black beauties

Are chosen for the screen

That you may know

Your own sweet beauty

And not the white... ${ }^{6}$

The mother's insistence on reclaiming the beauty of her daughter challenges the 'ideal' of beauty enshrined not only in cinema and popular culture but also in British literature - a literature she is both positioned within and against.

Marson was also influenced by the poets of the Harlem Renaissance and infuses some of her poetry with an African-American musical aesthetic. In particular, she uses jazz and blues styles to articulate a pan-African sensibility. In "Kinky Hair Blues," which, as the title indicates, is scored in a blues form, Marson employs both Jamaican Patwa and African-American English to again challenge white standards of beauty and affirm pride in her racial and physical characteristics: “And I don't envy gals / what got dose locks so fair / I like me black face / and me kinky hair" ${ }^{\prime 6}$ While Lloyd Brown critiques Marson's blues poems by suggesting that the "heavier rhythms of the blues form do not harmonize well with the rapid cut-and-thrust of the Jamaican folk mood and folk style, ${ }^{, 67}$ I believe she succeeds in merging the two. Indeed, the dialogue at play between jazz/blues stylises and Patwa provides Marson with an inspiring vocabulary with which to explore and celebrate African-Jamaican folk culture.

With its call-and-response pattern, "Mango Time Again" is another demonstration of Marson's literary experimentations. Where most of the Caribbean

\footnotetext{
${ }^{65}$ Una Marson, The Moth and the Star (Kingston, Jamaica: The author, 1937): 87-88.

${ }^{66}$ Marson, The Moth and the Star, 91.

${ }^{67}$ Lloyd Brown, West Indian Poetry (Boston M A: Twayne, 1978): 37.
} 
literary works of this period focused on capturing the British environment, even going so far as to comment on such imported alien experiences as snow, ${ }^{68}$ Marson employs a fresh language to explore Jamaican landscapes and reality, in this case describing mango season: "Not gwine hungry any more / Mango start fe ripe, / Not gwine stay inside me door / Mango start fi ripe. ${ }^{\prime 69}$ Here, the language harkens back to the long oral tradition of African-Jamaican work songs and spirituals, while her poems "Cane Field Blues," "Lonesome Blues," and "Baby Blues" from the same collection adopt a more jazz/blues cadence. In "Brown Baby Blues," for instance, the speaker of the poem, bewails her current circumstances as a single mother and imagines the future of her mixed-race child. The blues form, along with the repetition and gestures at improvisation, captures the lamentation of the mother's thoughts: "I got a brown baby / sweet as can be", "Why I is so black, / An' she's so brown." And, in a typical recursion to the spiritual dimension of black folksong, the poem invokes God in its concluding lines. This mother sings a real blues: "Lord send her papa back; your mother close love you / and your colour is high. ${ }^{77^{0}}$

Marson's literary experiments paved the way for future black women writers. Decades later, for example, the Guyanese writer Grace Nichols picked up where Marson left off, in her poetry volume The Fat Black Woman's Poems (1984), in which she combines Guyanese creole vocabulary with jazz-based rhythms to document the black female experience, challenge European notions of beauty, and celebrate a black aesthetic. This tie between music and literature is a recurring feature of black disaporic writing and an expression of pan-Africanism. See, for instance, how the Afro-Cuban writer Nicolás Guillén draws inspiration from the son, and how Anglo-Caribbean poets use the rhythms of calypso and reggae to inform their structural and literary forms and represent the ethos of black folk cultures. Similarly, there has been a long tradition of dialogue between African-American and Afro-Caribbean artists. ${ }^{71}$

\footnotetext{
${ }^{68}$ Brathwaite, History of the Voice, 8-9.

${ }^{69}$ Marson, The Moth and the Star, 87.

${ }^{70}$ The Moth and the Star, 97.

${ }^{71}$ This devolves, of course, from the sociohistorical dimension of Caribbean migration to the USA, where anglophone West Indians were prime movers in the shaping of the Harlem Renaissance. Percipient early views of this migration and its influence on cultural politics include: Eric Walrond (himself a West Indian migrant), "The Hebrews of the Black Race," International Inter-
} 
Unfortunately, with the exception of a few Caribbean literary critics who have, for instance, discussed the influence of jazz on Caribbean literature, ${ }^{72}$ research in this area is still lacking. Nevertheless, it is clear that as Négritude writers and those of the Harlem Renaissance drew inspiration from each other, McKay and Marson, too, were inspired by African-American and other diasporic African cultures and played with these forms in their work. We see a continuity of this tradition of exchange today in, for instance, the flow between contemporary African diasporic musics such as the mixing of hip-hop with dancehall and Afro-Cuban sounds with afrobeat.

Marson's poetry, like McKay's, dwelt on ordinary Jamaicans. The poem "The Stone Breakers" demonstrates her commitment to giving voice to the lived experiences of African-Jamaican women through the poetic style of a work song. As in McKay's "Quashie to Buccra," the poetic personae in "The Stone Breakers" conveys the gruelling nature of women's work:

fe buy frack fe de pickney dem

Ebry day dem hab fe feed...

Me back hat me,

Me foot hat me

An' Lard, de sun a blin' me. ${ }^{73}$

The female personae also mince no words in their articulation of the economic disparity between black Jamaicans and white colonials: "de backra car dem / a lik up de dus' in a we face. ${ }^{74}$ On the other hand, in contrast to McKay's Quashie, who finds a certain pride in his work, the women of Marson's poems

preter (14 July 1923): 468-69, and Ethelred Brown \& Eugene Kinckle Jones, "West IndianAmerican Relations: A Symposium," Opportunity 4 (November 1926): 355-56, and a more recent appraisal can be found in Sean X. Goudie, "New Regionalisms: US-Caribbean Literary Relations," in A Companion to American Literary Studies, ed. Caroline Levander \& Robert Levine (Chichester: Wiley-Blackwell, 2011): 310-14.

${ }^{72}$ See, for example, L. Edward Brathwaite, "Jazz and the West Indian Novel," Bim 11/44 (January-June 1967): 275-84; 12/45 July-December 1967): 39-51; 13/46 (January-June 1968): 115-26; repr. in Edward Kamau Brathwaite, Roots (1986; Ann Arbor: U of Michigan P, 1993): 55-110.

${ }^{73}$ Marson, The Moth and the Star, 70.

${ }^{74}$ The Moth and the Star, 70. 
do not get the same satisfaction from their labour. Instead, they criticize their circumstances and the sexism of their men: ${ }^{75}$

dem wotless papa tan roun' de bar

A trow dice all de day....

De groun' is dat dry,

Nota ting will grow $-{ }^{76}$

Marson is also aware, however, of the trials of having no work at all. In "At the Prison Gate," a group of working-class Jamaican men march to the gates of a prison to ask the Director if they can join his band of prisoners:

And works so that we are fed...

And I hear a great stir of voices

Among those who rule the land

In politics and those who rule in gold

but the tramp of the weary feet still sounds... ${ }^{77}$

Read from the indigenous perspective that VéVè Clark's diaspora literacy calls for, the poem reveals the extreme harshness of the social conditions that would force black Jamaican working-class men to volunteer to become prisoners so they can eat. This nuanced reading also responds to the criticism of the female voices in "The Stone Breakers" by contextualizing the social conditions that often deny working-class men the opportunities for work and meaningful economic participation in family life, thus providing a balanced Jamaican feminist perspective. The poems in The Moth and the Star, especially "The Stone Breakers," thus serve as strong examples of Marson's development as a poet interested in using not only Patwa but also folk knowledges in her endeavour to challenge the hegemony of European literature and feminist discourse and celebrate Jamaican culture.

Like McKay, Marson also incorporates a black spiritual ethos in her work. Faced with despair, her stone breakers turn to God:

${ }^{75}$ This is in contrast to other earlier Jamaican writers such as George Campbell, whose poem "History Maker" romanticizes women's strength and endurance and writes them as iconic black superwomen: "Women stone breakers / hammers rocks / [...]. / strong thighs /rigid legs / no smiles / no moan"; Campbell, "History Makers," in Campbell, First Poems (1945; New York: Garland, 1981): 32 .

${ }^{76}$ Marson, The Moth and the Star, 70.

77 The Moth and the Star, 86. 
Massy, Lard, is life is hard

An' so - dough de work is hard

I will haste to work fe pittance

Till de good Lard call me. ${ }^{78}$

Unlike McKay's assumed atheism, Marson's biography suggests that she saw religion as a vehicle to advance racial and gender struggles among people of African descent globally. ${ }^{79}$ Marson's unpublished play Pocomania (1938) signals an even stronger commitment to anti-colonial struggle because of the ways it offers a powerful literary counter-discourse. Indeed, Pocomania has been cited for its importance as "an early literary attempt to connect Africa with the Caribbean" and is touted as the first-known example of a Caribbean play to employ an African-Jamaican religious ritual in its dramatic structure. ${ }^{80}$ As Carolyn Cooper maintains, the play

is remarkable for its sophisticated handling of Jamaican creole; its dramatic deployment of Afro-Jamaican religious ritual as theatrical device; and from its foregrounding of gender in the conflict of cultural values in which the play is structured. ${ }^{81}$

In the play, Stella Manners, a middle-class character and the central protagonist, seeks to reconnect with her past through Pocomania. ${ }^{82}$ Although she was fascinated by the drumming of the religion as a child, it is not until she reaches adulthood that Stella has the opportunity to experience its rituals at first hand, when, in order to release herself from grief at the loss of her husband-to-be, she ventures (in disguise) to various Pocomania ceremonies. Here she is able to find relief by temporarily disappearing: "there is no spirit here now she is gone. ${ }^{\prime \prime 3}$ Stella also draws strength and knowledge from the revivalist leader Sister Kate, who constitutes a spiritual and alternative mother. It is through Sister Kate that Stella learns the meaning of spiritual possession and that the

\footnotetext{
${ }^{78}$ Marson, The Moth and the Star, 70.

${ }^{79}$ Delia Jarrett-Macauley, The Life of Una Marson 1905-1965 (Manchester: Manchester UP, 1998): 134 .

${ }^{80}$ Jarrett-Macauley, The Life of Una Marson, 135 .

${ }^{81}$ Cooper, "'Something Ancestral Recaptured'," 68.

${ }^{82}$ Pocomania is an African-derived Jamaican folk religion. See Maureen Warner-Lewis, The Nkuyu: Spirit Messengers of Kumina (Mona, Jamaica: Savacou, 1977): 3-13.

${ }^{83}$ Una Marson, "Pocomania Collection" (MS, Kingston: Institute of Jamaica, 1938): 34.
} 
rhythms of the drums have been passed down over generations, starting with the first enslaved Africans:

Stella: I don't know whether I like them [the drums] or not. They frighten me alittle but they certainly fascinate me.

Sister Kate: Fascinate, Miss Stella? Dem is more wonderful dan dat! Troo de drum de spirit speaks - de Lawd Himself speak to de soul of him people.

Stella: Is it the drums that make the people shout and groan and roll unconscious on the ground? $?^{84}$

Here, Marson anticipates Christel Temple's literary pan-Africanism (how writers use characters to metaphorically or spiritually journey between Africa and the diaspora to gain understanding).

Additionally, Marson follows McKay's lead in using characters to uncover the snobbery of and contempt levelled at African-centred practices and rituals. In this case, Stella's family members represent this view. Throughout the play her sister, Dawn, puts down Pocomania, dismissing the drumming ceremonies as "noise" and referring to its participants as "dreadful." Stella's father, Deacon, and her Parson, go even further, condemning Pocomania for its "devilish" influence on the people and pressuring Sister Kate to put an end to her services. ${ }^{85}$ While some critics have suggested that Pocomania presents a simplistic view of the religion, revealing evidence of middle-class voyeurism, I argue, as do Cooper and others, that Marson's integration of these rituals into her writing is a mark of profound respect. In an interview, Marson herself refers to Pocomania as "the nearest thing to Africa that we have in the West Indies [... proof that] our African ancestry is still with us. ${ }^{\prime 86}$ Clearly, Marson understands her work to be in the context of what Christel Temple calls the Sankofa model, in which black literatures look to the past to chart a future, thereby shifting eurocentric frames to black-centred understandings of the world. ${ }^{87}$ While it is understood that Pocomania does not constitute an 'authentic' past link with

\footnotetext{
${ }^{84}$ Marson, "Pocomania Collection," 3.

85 "Pocomania Collection," 9.

${ }^{86}$ Una Marson, "Meet the Colonies" (Reading: West Indies Service, B BC Written Archives, 3 April 1945): 40.

${ }^{87}$ Christel Temple, "Rescuing the Literary in Black Studies." Journal of Black Studies 36.5 (May 2006): 780 .
} 
Africa, it represents a modern cultural form that functions as an archive of African traditions, traditions that have been repressed in the wider society. As such, Marson's radical approach to the subject allows us to think of AfricanJamaican religious forms as living archives that continuously transform the relation to the very past that they preserve in their repertoire of rituals and practices. Indeed, as with McKay's Bita Plant, Stella embodies a metaphorical return to an African past and identity.

Marson, however, does not shy away from discussing "the problems inherent in such a journey. ${ }^{\prime 88}$ This is evident in Stella's conflicted relationship with Sister Kate and Pocomania. In her careful analysis of African diasporic novels, Carolyn Cooper posits that Bita Plant and Stella, among others, are part of a significant tradition of cultural recovery:

In all of these feminist fictions of the African diaspora the central characters are challenged, however unwillingly, to reappropriate the 'discredited knowledge' of their collective history. The need of these women to remember their 'ancient properties' forces them, with varying degrees of success, to confront the contradictions of acculturation in societies where the press toward upward social mobility' represses Afrocentric cultural norms. ${ }^{89}$

While I concur with Cooper's observations, I am also aware of the importance of noting that betrayal of race is a notion which has often, and problematically, been inscribed on the black female body. Stella's desire, like Bita's, to reconnect with Jamaican folk culture demands that she carry the burden of national cultural responsibility. It is women, then, who are always called upon to be the bearers of culture. Marson fails in this instance to trouble this position, which is reflected widely in literature, film, and popular music.

Notwithstanding Marson's failure to treat the notion of women as repositories of cultural heritage with due differentiation, the use of local folk culture in Pocomania is important for signalling Marson's acknowledgment of the religious and class tensions intertwined in assertions of African identity. The scene between Sister Kate, Deacon Manners, and Parson Craig, for instance,

\footnotetext{
${ }^{88}$ Snaith, “'Little Brown Girl' in a 'White, White City', 105.

${ }^{89}$ Carolyn Cooper, "Afro-Jamaican Folk Elements in Brodber's Jane and Louisa Will Soon Come Home," in Out of the Kumbla: Caribbean Women and Literature, ed. Carole Boyce Davies \& Elaine Savory Fido (Trenton NJ: Africa World Press, 1990): 284.
} 
embodies the dichotomy between Protestants and africanized Christians. Marson's characters who shun Pocomania are anticipate Cabral's urban or peasant petite bourgeois who look down on their own indigenous cultures in their desire to assimilate to colonial cultures. ${ }^{90}$ Stella presents an alternative in which African cultures are reclaimed despite their suppression in the name of Caribbean middle-class respectability. Interestingly, although Pocomania contains both Christian and African elements, Marson chooses to highlight only its African origin, thereby de-privileging its Euro-Christian features. The actual performance of a revival meeting on stage is very much an act of decolonization. Indeed, playing such a scene at a time when Pocomania was marginalized and illegal in Jamaica, and in what was considered eurocentric space the proscenium stage - was radical. Marson's use of Pocomania in this manner "destabilizes received formulation and enables the marginalized to return at least to haunt the marginalizer..$^{91}$ It also accords with Dei's description of anticolonial art as a project in which "indigenous knowledge should be critical and oppositional in order to rupture stable knowledge. ${ }^{92}$ Both McKay and Marson illustrate transgression of European elite values, but whereas McKay's Bita achieves a total transformation of identity by marrying Jubban, a rural peasant, Stella ends up conforming to conventional middle-class notions of marriage, as expected of her. The authors thus make different choices about how to represent the pressures and possibilities of their character's quests for liberation from a colonial world-view.

African-centred religion is once again foregrounded in Marson's poem "Gettin' de Spirit." Here she uses Patwa to dramatize an indigenized Christianity in which praise worship is offered as an alternative way of communicating with God:

Lord gie you chile de spirit

Let her shout

Lord gie you chile de power

\footnotetext{
${ }^{90}$ Amilcar Cabral, "National Liberation and Culture," in Return to the Source: Selected Speeches of Amilcar Cabral (New York: Monthly Review Press, 1973): 39-56.

${ }^{91}$ Josaphat Kubayanda, On Colonial/Imperial Discourse and Contemporary Critical Theory (College Park: U of Maryland P, 1990): 6.

${ }^{92}$ Sefa Dei, Rethinking the Role of Indigenous Knowledges in the Academy, 17.
} 
An' let her pray -

Hallelujah - Amen. ${ }^{93}$

In "God and Armaments," Marson imagines God speaking in the patiently monotonous voice of an Anglican minister, but in "Gettin de Spirit" God shouts: "Shout sister - shout - / God is sen' you His spirit / Shout sister - shout / Hallelujah - Amen. ${ }^{\prime 94}$ This description of 'getting the spirit' is repeated in the scenes of spirit possession in Marson's Pocomania:

Join de chorus

We feel it flowing o'er us

You is no chile of Satan

So get the spirit

And shout, Sister, shout

Hallelujah, Amen

Shout, Sister Shout. ${ }^{95}$

Decades later, the dub poet Mutabaruka will pick up on Marson's explorations of African-centred religion. His poem "Retrieve," for instance, also locates Pocomania as a celebration of African roots and source of liberation. ${ }^{96}$ Certainly one can see how the taking-up of African-Jamaican religions by early black nationalist writers like Marson and McKay set a path for future black writers with a similar commitment to social transformation. ${ }^{97}$

Marson's poem "Quashie Comes to London" shifts the discussion to the Jamaican diaspora. The poem displays a diasporic aesthetic, employed both to express the expatriate longing for home and to offer commentary on the social situation of black communities in adopted host countries. In the poem, Quashie embodies a country-bumpkin archetype who makes the transformative journey of emigration to the metropolis. Writing in the vernacular, Marson depicts the response of a homesick black Jamaican residing in London:

${ }^{93}$ Marson, The Moth and the Star, 76.

94 Marson, The Moth and the Star, 76.

95 Marson, "Pocomania Collection," 9.

${ }_{96}^{6}$ Mutabaruka, The First Poems 1970-1979 (Kingston, Jamaica: Paul Issa, 1980): 46.

${ }_{97}$ Other brown and white nationalist writers incorporated African-Jamaican cultural themes and forms in their work. See, for example, Philip Sherlock's poem "Pocomania" (1943), in The Penguin Book of Caribbean Verse in English, ed. Paula Burnett (Harmondsworth: Penguin, 1986): 154-55. 
An' sometimes jes when I feel gran'

Dere sitting all alone,

Dem play some tune dat takes me home

In sweet and soulful tone

An' de tears dem well up in my eyes

An' I try fe brush dem way,

But me heart gets full and dough I try

Dem simply come fe stay. ${ }^{98}$

In a later, comical scene, Quashie goes into a restaurant and attempts to order the cuisine of his African-Jamaican working-class past: "some ripe breadfruit, / Some fresh ackee and saltfish too / An'dumpins hot will suit." When the waitress informs him they do not have any such things and hands him the menu, he refrains from ordering anything, commenting: "It's den I miss me home sweet home / good ole rice an peas. ${ }^{\prime 99}$ Despite the humour here, we see Marson using food imagery in much the same way as McKay does in "Tropics in New York" to signal a symbolic yearning for the past and the absence of cultural nurturing, which invokes the alienation and homesickness latent throughout the poem. Indeed, "Quashie Comes to London" ends on a serious note as Quashie reflects on the alienation he feels in Britain, telling his friends back home in Jamaica:

It is not gwine be anoder year

Before you see me face,

Dere's plenty dat is really nice

But I sick fe see white face. ${ }^{100}$

Unlike McKay's Quashie, who uses his local language in his local environment, Marson's character faces a greater challenge because he has to re-position his local language and beliefs within the Empire, where those beliefs are trivialized. Yet, his insistence on invoking his own set of referents and cultural memory affirms their importance, particularly in this alienating context. This is one example of the necessary flows of indigenous knowledges from one social and cultural environment to another.

While I have already mentioned the important links between the works of McKay and Marson and the dub poets and roots reggae artists who were to

\footnotetext{
${ }_{98}^{8}$ Marson, The Moth and the Star, 18.

${ }^{99}$ The Moth and the Star, 20-21.

${ }^{100}$ The Moth and the Star, 21.
} 
follow, the significant differences in the time periods in which they created art must also be acknowledged. Marson and McKay worked at a time when access to literacy and literature among the rural peasant and urban working-class of Jamaica was extremely low. In the early part of the twentieth century, the Jamaican public simply did not purchase books. Indeed, according to Henry Swanzy, "not a single bookstore existed in Kingston, Jamaica in 1930."101 Given such a reality, it is not surprising that Marson and McKay worked within Western canonical forms. How else might they have ensured themselves of an audience for their work? Thus, taking into account the literary constraints under which both authors worked, I would suggest that their use of Western literary forms is not, on its own, a sufficient reason to ignore or reprove their contribution to an African-Jamaican aesthetic and a literature of decolonization.

Furthermore, Marson and McKay's use of the Western literary form was in many ways inevitable in view of the colonial context from which they emerged. Indeed, their early work was naturally shaped by their educational training an education that encouraged and promoted British superiority, on the one hand, and black inferiority, on the other. Leo Oakley notes that "the literature was really a by-product of an educational system geared to ensure loyalty to England and designed to make us look outside for standard and values" ${ }^{102}$ This brings to mind Du Bois's classic work on African American double-consciousness. I would extend this notion in the case of Afro-Caribbean peoples and suggest that multiple consciousnesses are often at play in a juggling of competing identities: Europe, Africa, Asia, and the Americas. Indeed, Hugh Hodges argues that Caribbean cultural identities "do not always reflect the 'double consciousnesses' that Gilroy identifies as characteristic of Black Atlantic cultures."103 Stuart Hall also acknowledges this in his discussion of différance, a notion he borrows from Derrida to describes the possibility of rethinking

${ }^{101}$ Henry Swanzy, "The Literary Situation in the Contemporary Caribbean" (1956), in The Routledge Reader in Caribbean Literature, ed. Alison Donnell \& Sarah Lawson Welsh (London: Routledge, 1996): 249 .

${ }^{102}$ Leo Oakley, "Ideas of Patriotism and National Dignity" (1970), in The Routledge Reader in Caribbean Literature, ed. Alison Donnell \& Sarah Lawson Welsh (London: Routledge, 1996): 92.

${ }^{103}$ Hodges, Soon Come:Jamaican Spirituality, Jamaican Poetics, 13. 
the positioning and repositioning of Caribbean cultural identities in relation to at least three "presences," that borrow from Aimé Césaire's and Léopold Senghor's metaphors: Présence Africaine, Présence Européene, and Présence Américaine. ${ }^{104}$

Hodges offers another view on the topic altogether. Using what he calls "Rastafarian consciousness," he contends that

Rasta consciousness is not double in Gilroy's sense of the word. Rasta experiences neither the ambivalence of the black person living simultaneously inside and outside the white, nor the double consciousness of the modern. There is no doubling ambiguity in the Rasta mind about neither Babylon (they reject it) nor any doubling sense of the present as novelty (the past is concretely present and continuous). ${ }^{105}$

Hence, Rasta consciousness disrupts the tension of duality in black identity because it is able to outwardly (without reservation) express and adapt local cultures within their changing environment. As well, this consciousness is later affirmed to a greater degree in the works of the dub poets and other cultural producers who treat the "past [as] concretely present and continuous."

Marson's and McKay's works gave voice to an indigenous African-Jamaican consciousness seeded in African traditions. We see this same approach in writings by their peers from other Caribbean nations. The poet Nicolás Guillén, for instance, drew on African-Cuban 'Africananism' to confront issues of race, class, and economic imperialism, and to legitimize black culture as the basis of an indigenous Cuban literature. According to current definitions of indigenous knowledges, folklore, proverbs, and poems are fundamental to the preservation and future of cultures. ${ }^{107}$ Perhaps it is not surprising, then, that these are the very literary devices many Caribbean writers, including Marson and McKay, brought to their writing. Marson and McKay were undoubtedly part of the first wave of authors attempting to indigenize Caribbean literature and as such had

\footnotetext{
${ }^{104}$ Hall, "Cultural Identity and Diaspora," 240.

${ }^{105}$ Hodges, Soon Come:Jamaican Spirituality, Jamaican Poetics, 14.

${ }^{106}$ Soon Come: Jamaican Spirituality, Jamaican Poetics, 14.

${ }^{107}$ Elizabeth McIsaac, "Oral Narrative as a Site of Resistance: Indigenous Knowledges, Colonialism, and Western Discourse," in Indigenous Knowledges in Global Contexts: Multiple Readings of Our World, ed. George J. Sefa Dei, Budd L. Hall \& Dorothy Goldin Rosenberg (Toronto: U of Toronto P, 2000): 91 .
} 
to chart new artistic ground in opposition to the dominant colonial literary milieu from which they emerged. Of course, Marson and McKay are also noteworthy as diasporic writers who were influenced by other artists from a myriad of points across the African and black-diasporic world. More specifically, they are part of a tradition of diasporic authors whose literary work served as a vehicle for forging new space in adopted host countries while simultaneously expressing their cultural continuity with 'back home'.

The conclusion of this chapter involves a very brief discussion of dub poetry in order to contextualize its role as a literary artform drawing crucially on African-Jamaican aesthetic impulses. While I am aware of Jamaican novelists and playwrights who persisted in the project of literary decolonization by adhering to an African-Jamaican aesthetic and local culture during the nationalist movements for Caribbean cultural sovereignty, I have chosen instead to end here with early dub poets for a number of reasons. First, dub poets and literary critics alike ${ }^{108}$ often credit their development of the artform exclusively to Louise Bennett. Although I agree that Bennett's work has had a tremendous influence on these dub artists, I think it is also worthwhile indicating the similarities and influence dub poets share with earlier writers such as McKay and Marson. Despite their use of colonial-influenced models and their middle-class status, these two literary figures can be seen as key precursors of dub poetry for their bold contributions to literary decolonization. The work of the dub poets to follow also works in unison with the diasporic dubbist (analysed in subsequent chapters) in their adaption of an AfricanJamaican aesthetic in their new environments.

${ }^{108}$ Like many literary critics, Mutabaruka often cites Louise Bennett as the leading influence on dub aesthetics, especially for her bold use of creole in the literary and scribal form (Lisa Tomlinson, personal interview with Mutabaruka, 15 August 2003.) It is also worth noting the influence that Claude McKay's early poetry had on Louise Bennett when, as a young girl, she was given a copy of his book of poems by her teacher. McKay's work introduced Bennett to one of the first Jamaican poets to bring local language into the literary tradition; Edward Kamau Brathwaite, "English in the Caribbean: Notes on Nation Language and Poetry," in English Literature: Opening Up the Canon, ed. Leslie A. Fiedler \& Houston A. Baker, Jr. (Baltimore MD: Johns Hopkins UP, 1981): 28 . 


\section{The Reggae Aesthetic: Dubbing as a New Literary Voice}

Reggae music has long been recognized as important for representing the lives and realities of poor and working-class black Jamaicans; indeed, the music carries within it "deep dissonance which mirrors the social conflict in society."109 Marked by a history of slavery and colonialism and a present of globalization, Jamaican society today is one where poverty, crime, unemployment, and exploitation are rampant. ${ }^{110}$ It is on this ground that reggae and dub poetry emerged, on the wings of the Rastafari movement, as artforms seeking to give voice to the African-Jamaican working-class struggle against oppression. Dub poets linked the aesthetic of reggae to the power of the spoken and written word to break through the cultural hegemony of colonial literature. Their exhilarating and liberating oral expositions of national consciousness and identity ${ }^{111}$ and use of African-Jamaican indigenous knowledges clearly link them to their precursors - writers like McKay and Marson. In this section, I examine dub culture as a continuation of a tradition of literary decolonization, which is informed by African-Jamaican aesthetic impulses, pan-Africanism, Rastafarianism, and reggae.

Many dub poets took a radical step forward in the project of de-centering European literary aesthetics by insisting on a more expansive reservoir of indigenous knowledges and claiming a more "de-canonical way of thinking." One can see this de-centering, for example, in Marson's subversive use of parody in her poem "Cinema Eyes" as a political tool of resistance in how she inserts jazz and pan-African sensibility to assert and embrace black beauty:

I used to go to the cinema

To see beautiful white faces.

How I worshipped them!

How beautiful they seemed -

I grew up with a cinema mind. ${ }^{113}$

\footnotetext{
${ }^{109}$ Leonard E. Barrett, The Rastafarians (Boston M A: Beacon, 1997): 167.

10 Brathwaite, History of the Voice.

${ }^{\prime \prime}$ Cooper, Noises in the Blood, 83-84.

112 Kubayanda, On Colonial/Imperial Discourse and Contemporary Critical Theory.

${ }^{113}$ Marson, The Moth and the Star, 88.
} 
Mutabaruka uses the same approach in challenging eurocentric teachings in his "Nursery Rhyme Lament," in which he contorts British nursery rhymes to reflect local meanings and conjure up the harsh realities faced by poor Jamaicans:

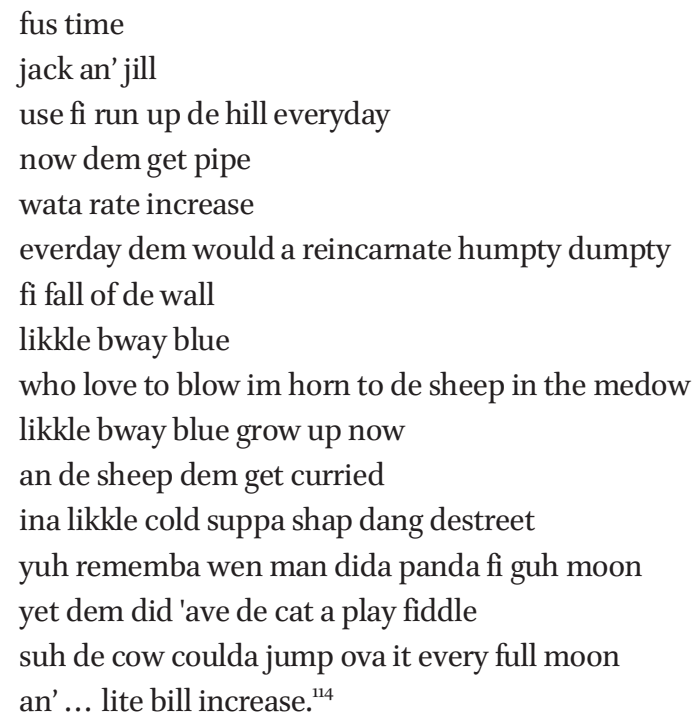

Here Mutabaruka echoes Marson, McKay, and other early writers in using the vernacular to speak directly to, and for, black Jamaicans. He closes his poem by affirming the vitality and value of indigenous Jamaican literature: "fus time man use fi lov' dem / but dem deh days dun / an wi write." ${ }^{115}$

Like his peers, the dub poet Mikey Smith also offers an ironic twist on British nursery rhymes (employing children's ring games and proverbs), this time to expose the difficult realities of Kingston's slum communities:

Room dem a rent

Mi apply widdin

but as me go een

cock-roach rat and scorpion

${ }^{114}$ Mutubaraku, "Nursery Rhyme Lament," in Jah Lyrics: Reggae Archives, http: //www.jahlyrics.com/index.php?songid $=5585$ (accessed 16 September 2011).

${ }^{115}$ "Nursery Rhyme Lament," http://www.jah-lyrics.com/index.php?songid=5585 (accessed 16 September 2011). 
also come een

Waan good

Nose haffi run

mi naw go sit dong pon high wall

like humpty dumpty

me a face reality. ${ }^{116}$

Mutabaruka and Mikey Smith's re-imagining of British nursery rhymes to express black Jamaican culture is a natural evolution from McKay and Marson's use of British poetic forms for the same purposes. But Mutabaruka, Smith, and many of their dub peers go further than their predecessors in explicitly criticizing the cultural insignificance of colonial education and, fuelled by Rasta consciousness, exposing its damaging effects on the native psyche. Although McKay and Marson embraced an African-Jamaican resistance aesthetic, they still saw themselves as British subjects. ${ }^{117}$ In McKay's poem "Old England," for instance, the persona expresses affinity with, and a burning desire to visit, the 'motherland': "Just to view de homeland England, in de streets of London walk...." A few verses later, the persona also expresses patriotism for Jamaica:

An' dese places dat I sing of now shall afterwards impart

All deir solemn sacred beauty to a weary searchin' heart;

So I'll rest glad an' contented in me min' for evermore,

When I sail across de ocean back to my own native shore. ${ }^{118}$

Here we see the tension between "de homeland" in the second verse and "my own native shore" in the last verse, suggesting the contradictions and duality inherent in the colonial subject's identity. In contrast, the dub poets who followed were writing in the post-Independence era and therefore better able to move beyond thinking of themselves in British terms, which simultaneously opened up further space for reclamation of Africa as the true root of home.

${ }^{116}$ Michael Smith, It A Come: Poems, ed. \& intro. Mervyn Morris (San Francisco: City Lights, 1989): 13 .

${ }^{117}$ James, A Fierce Hatred of Injustice; Jarrett-Macauley, The Life of Una Marson 1905-1965; Tyrone Tillery, Claude McKay: A Black Poet's Struggle for Identity (Amherst: U of Massachusetts P, 1992).

${ }^{118}$ McKay, Complete Poems, 46. 
For Marson, ironically, it is not until she actually travels to England that she questions her 'British' identity as revealed in her poem "Nigger," which relates the taunting of London street children:

They called me 'Nigger'

Those little white urchins

They laughed and shouted

As I passed along the street,

They flung it at me:

'Nigger! Nigger! Nigger!"19

Marson's reflections here are in sharp contrast to her earlier poem "To Hampton," in which she expresses longing for the colonial education she received at her alma mater:

Ah me, the cares of Latin and French,

And of the long hours spent upon the bench,

The toils of writing prose and conning rhymes

To us no doubt, did seem large ones at times.

$[\ldots]$

How oft in dreams I live those days again,

Chasing a hockey ball with might and main,

Or sit and list without a thought of fear

To dearest Mona reading great Shakespeare. ${ }^{120}$

It takes exposure to blatant racism for Marson to begin to truly perceive of herself as black. Of course, this was a common experience for colonial subjects. Frantz Fanon famously wrote of first coming to racial awareness in the face of French-Algerian racism. ${ }^{121}$ McKay had much the same experience of racism as Marson while living in London in 1919-20. Winston James notes that it was in this period that McKay learnt "he was not British, in any meaningful sense beyond the juridical, imperial one." ${ }^{1122}$ Despite a colonial education in which they were taught to think of themselves as British (and Britain as their motherland), when McKay and Marson travelled to England themselves they both en-

11 Una Marson, "Nigger," The Keys 1.1 (July 1933): 8-9.

120 Una Marson, Tropic Reveries (Kingston, Jamaica: The author, 1930): 70.

${ }^{121}$ Frantz Fanon, Black Skin, White Masks, tr. Charles Lam Markmann (Peau noire, masques blancs, 1952; tr. 1967; New York: Grove, 2004): 111-12.

${ }^{122}$ James, A Fierce Hatred of Injustice, 96. 
counter "the long-imagined cultural mother who rejects her wooly headed children." ${ }^{123}$

For many early dub poets coming of age in the era of Jamaican independence, Rastafarian culture provided an alternative and powerful grounding. ${ }^{124}$ Rather than writing in opposition to a eurocentric Christian world-view from within, as Marson and McKay often did, dub poets were able to employ a Rasta aesthetic to challenge oppression from an afrocentric point of view. Mutabaruka's poem "Say (for ODUN)" provides an excellent example of the link between dub poets, Rastafarian religion, African identity, and the struggle for justice. In the poem, Mutabaruka turns his gaze away from Europe and re-imagines Ethiopia as a promised land for Africans living in the diaspora: "When you remember home / say: Ethiopia." ${ }^{125}$ Similarly, in "Sunday," Mikey Smith rejects the christianized model of prayer and after-life salvation, writing instead of a deep spiritual meditation (an important aspect of Rastafarian religion), which provides strength for the journey to freedom:

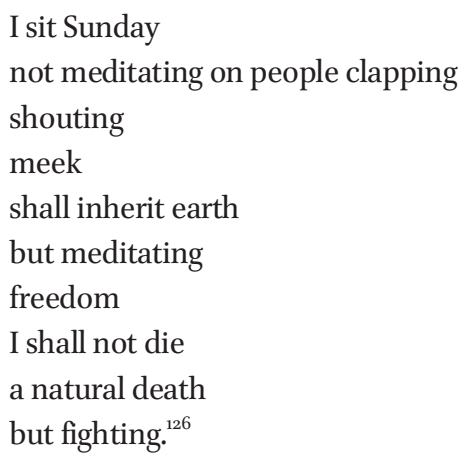

In addition to the use of Rastafarian spirituality as a basis for anti-colonial expression, dub poets also used the music of the faith in their work. While Marson and McKay turned primarily to jazz and blues for their musical inspiration, dub poets integrated mento (Jamaican folk music) and reggae in their

${ }^{123}$ Gerald Moore, The Chosen Tongue: English Writing in the Tropical World (London: Longmans, Green, 1969): 40.

${ }^{124}$ The inclusion of a Rastafarian ethos in literary form is not unique to dub poets. Roger Mais' novel Brother Man (1954), for example, portrayed a Rasta protagonist.

${ }^{125}$ Mutabaruka, The First Poems 1970-1979, 23.

${ }^{126}$ Smith, It A Come: Poems, 37. 
work. ${ }^{127}$ Dub poets also continued Marson's and McKay's commitment to panAfricanism, celebrating Africa as the seat of civilization rather than as the 'savage' continent imagined by Europe. Mutabaruka's recording "Great Queens of Africa," for instance, recalls African queens to honour the resistance of black women to oppression:

Great Queens of Africa

rulers all around

they were might brave and strong

Europeans couldn't get them down...

Nanny (when de English dem lick shot All she do is spit it back). ${ }^{128}$

Mutabaruka's recorded poem is somewhat unique in putting the contributions of black women to African and Caribbean history centre stage; however, its thematic insistence on black self-determination and liberation is in keeping with his work. Indeed, the poem is an example of Dei's reflection that "an anticolonial approach is also a celebration of oral, visual, textual, political, and material resistance of colonized groups - a site away from a sole preoccupation with victimization. ${ }^{\text {m29 }}$

In The Wretched of the Earth, Frantz Fanon challenges the carriers and creators of culture to participate in popular resistance beyond the confines of the classroom or the safety of secluded writing spaces. ${ }^{130}$ Many dub poets can certainly be said to have heeded this call, using their art to inspire grassroots activism and provide popular education to the masses. Their approach is in keeping with the African griot tradition. The incorporation of reggae and emphasis on orality have been particularly effective in enhancing the accessibility of dub poetry to the general public. The Jamaican Canadian Lillian Allen describes dub poetry as "art to go" or "take out art" and posits that it disrupts the notion of the solitary reader of Western poetry/literature. ${ }^{131}$ The accessible and com-

${ }^{127}$ Marson, inadvertently, has ties to reggae via "War," the famous speech she prepared and edited for Haile Selassie, which found its way into the music of Bob Marley.

${ }_{128}$ Mutubaraku. "Great Queens of Africa," Jah Lyrics: Reggae Archives, http://www.jah-lyrics .com/index.php?songid=5553 (accessed 16 September 2011).

${ }^{129}$ Dei, Rethinking the Role of Indigenous Knowledges in the Academy, 8.

${ }^{130}$ Fanon, The Wretched of the Earth, 241.

${ }^{131}$ Lillian Allen, Women Do This Every Day: Selected Poems of Lillian Allen (Toronto: Women's Press, 1993): 17 . 
munitarian aspects of dub poetry make it an ideal form for mobilizing community activism and asserting cultural identity. While earlier Jamaican writers attempted to subvert European literary forms in their claiming of an indigenous black aesthetic, dub poets can be said to have radically separated from the foundational elements of the Western literary canon.

\section{Revitalization of a National Voice}

Chapters 1 and 2 have focused on providing a theoretical and comparative analysis of Jamaican literature. More specifically, I have tried to map out a number of important features including creative immersion in indigenous black culture and spirituality (the Jamaican aesthetic), the adoption of Patwa, and the centrality of pan-Africanism. The works of McKay, Marson, and the dub poets profiled can be more profitably read within this contextual understanding of the early Jamaican literary landscape. The authors in question all serve as instructive examples of the anti-colonial framework laid out by Dei in which art can act as a site of empowerment and resistance by subverting colonial power and birthing new identities. ${ }^{132}$ They also demonstrate VèVè Clark's "diaspora literacy" - the need to read literature and art in its specific cultural and social contexts. ${ }^{133}$ These writers and poets - McKay, Marson, Mutabaruka, and Smith have collectively contributed to a body of writing that has (re)vitalized a national voice through an African-Jamaican aesthetic in the creation of a literature of decolonization - a tradition of resistance to hegemonic knowledgesystems and a re-shaping of the Jamaican literary tradition.

The chapters that follow move on to discuss dialogic cultural flows between Jamaica, London, and Toronto, particularly in terms of the mediated expressivity that helped to create local and diasporic identities for Jamaicans living abroad. London and Toronto are specifically chosen because of their histories as salient sites for African-Jamaican literary production; indeed, both are pivotal metropolitan centres where Caribbean literature and, in its turn, dub poetry have flourished.

${ }^{132}$ Dei, Rethinking the Role of Indigenous Knowledges in the Academy, 7.

${ }^{133}$ Clark, "Developing Diaspora Literacy and Marasa Consciousness." 


\section{3 \\ - Crossing Over to the Diaspora - \\ The Reggae Aesthetic, Dub, and the Literary Diaspora}

Memory is the selection of images. Some illusive, others imprinted indelibly on the brain. Each image is like a tread, each tread woven together to make a tapestry of intricate texture and the tapestry tells a story and the story is our past. $^{1}$

ESPITE FACING SIGNIFICANT SOCIAL INEQUALITY and migratory displacement, people of Afro-Caribbean descent in the diaspora have sustained a vibrant cultural reservoir through music, literature, and other forms of creative expressions. Commenting specifically on the Canadian context, Rinaldo Walcott notes that black Canadian artistic works "demonstrate the processes of black diasporic invention and (re)invention.. ${ }^{2} \mathrm{He}$ further suggests that these works should not be approached as "merely national products" but as creations that "occupy the space of the in between, vacillating between national borders and diasporic desires, ambitions and disappointments," and that, as such, they "suggest the possibilities of the 'new', but in many cases cannot leave various kinds of 'old' behind." I see Walcott's insistence on the continuity of the Afro-Caribbean aesthetic and culture as an important intervention in diasporic discourse. However, in the same book, Walcott focuses on diasporic exchanges to such an extent that, to some degree, he ahistoricizes

${ }^{1}$ Eve's Baptist monologue, taken from the film Eve's Bayou (dir. Kasi Lemmons; Trimark Pictures, US A 1997; 109 min.).

${ }^{2}$ Rinaldo Walcott, Black Like Who? Writing Black Canada (Toronto: Insomniac, 1997): xii.

${ }^{3}$ Walcott, Black Like Who? Writing Black Canada, xii. 
them. In his discussion of Lillian Allen's poem "I Fight Back," for instance, he suggests that she uses culture primarily as a springboard from which to combat antagonist sociopolitical forces in her adopted host country, thus downplaying its role in sustaining memory, identity, a sense of belonging, and a connection to 'home'. Similarly, while I appreciate the ways in which Paul Gilroy's Black Atlantic model offers an entry point into illustrating the flow of diasporic cultural exchanges, his valorization of these exchanges has a tendency to undermine the locality and indigeneity of cultures that are so central to an anticolonial framework. In the preface to Speshal Rikwes, the playwright and dub poet Ahdri Zhina Mandiela maintains that she employs Jamaican creole in her work because it "seems to yield more precise symbols, hence crisper, more de-

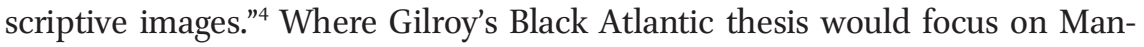
diela's cultural exchange within the diaspora, her comment suggests that her use of indigenous language is more about her immediate cultural identity than a response to her diasporic condition.

Arthur Paris avers that

Afro Caribbean literary expression and sensibility are not just rooted in the Caribbean, but in the metropoles of the former colonial (in the case of the US) and neo-colonial countries - London, Paris, Amsterdam, and Toronto for example. ${ }^{5}$

Paris's reflections here capture the fluidity of local cultures as they are continually uprooted and replanted. I point this out to make it clear that it is not my intention to 'fix' or homogenize Jamaican literature and culture as they are expressed in the diaspora. Rather, I am interested in finding a middle ground between static notions of the Caribbean, on the one hand, and theories of "postmodernist hyper-hybridity," on the other. As such, I argue that close examination of Jamaican literary productions reveals both a persistent continuity of African and Caribbean aesthetic modes and a dialogue with local and diasporic realities. Such a view proposes that while African-Jamaican diasporic identities are anchored in African and Jamaican cultural traditions, they are also fluid

\footnotetext{
${ }^{4}$ Silvera, "An Interview with Ahdri Zhina Mandiela: The True Rhythm of the Language," 8.

${ }^{5}$ Arthur Paris, "The Transatlantic Metropolis and the Voices of Caribbean Women," in Caribbean Women Writers: Essays from the First International Conference, ed. Selwyn R. Cudjoe (Wellesley MA: Calaloux, 1990): 82.
} 
enough to respond to local conditions and to enable dialogue across 'home' and diasporic borders. The following sections provide a close reading of the dub poetry of Lillian Allen, Afua Cooper, Linton Kwesi Johnson (LKJ), and Benjamin Zephaniah, exemplifying how their works reveal the retention and transformation of an African-Jamaican aesthetic; remain rooted in an African cultural tradition; disrupt the Canadian and UK literary canons (based as they are on a European model); and challenge racial, class, and gender discrimination.

\section{Dubbing the North Star: The Toronto Scene}

Dub poetry rose to prominence in Toronto, in the early 1980s. Echoing their Jamaican counterparts, Toronto's dub poets used the artform to comment on the inequities faced by people of African descent in the city, and to call for resistance. Working from such a culturally diverse city as Toronto transformed dub poetry so that it was no longer a singularly Jamaican form; it became a literary genre that allowed people from various Caribbean nations to voice a shared experience of life in Canada. In founding the Dub Poets Collective, for instance, the renowned African-Jamaican Canadian dub poet Lillian Allen was helping launch the career of the Antiguan Canadian Clifton Joseph, who became a major contributor to the Canadian dub poetry scene. However, I focus here primarily on the work of Lillian Allen and Afua Cooper to trace the continuities of the African-Jamaican aesthetic in diasporic locations and consider the re-conceptualization of 'home' away from home.

My analysis begins with Allen's seminal poem "Rub a Dub Style Inna Regent Park," which first appeared on the LP Revolutionary Tea Party and was later published in the book Women Do This Every Day. In her poem, Allen clearly refers back to her dub roots. Her repetition of the phrase "Oh Laawd," for instance, echoes the Jamaican dub poet Mikey Smith's signature line "Oh Laaaaawd" from his now classic dub poem "Mi Cyan Believe It." At the same time, she re-imagines dub to speak about the lived experiences of Afro-Caribbean people in Toronto's low-income community of Regent Park:

Monday morning broke

news of a robbery

Pam mind went

couldn't hold the load 
dem took her to the station

in a paddy wagon

screaming

her Johnny got a gun

from an ex-policeman

Oh Lawd, Oh Lawd Oh Lawd eh ya

forget yu bills them

an irie up yuself

forget yu dreams gathering dust

on the shelves. ${ }^{6}$

Here Allen's text exemplifies her integration of an African-Jamaican aesthetic with commentary on the localized realities of Afro-Caribbean people living in Toronto. The setting of Regent Park is a neighbourhood known for its large immigrant population, including a considerable number of people from the Caribbean. The community is also known for its low-income housing development, the oldest of its kind in Canada. "Rub a Dub Style Inna Regent Park" uses Patwa and reggae rhythms (also suggested in the title of the poem) to transplant a Jamaican dancehall street scene to a Toronto landscape, thus creating a new diasporic (artistic) space:

dj rapper hear im chant

pumps a music track

for im platform

cut it wild

set de system vile

dubbing it inna dance

frustration pile

a different style

inna Regent Park.?

The reggae and cultural critic Klive Walker notes that "Rub a Dub Style Inna Regent Park" was significant for the specificity of its representation of black

\footnotetext{
${ }^{6}$ Allen, Women Do This Every Day, 83.

${ }^{7}$ Women Do This Every Day, 82.
} 
Canadian community, an approach later creative writer and rappers would use in their commentaries on life in Toronto. ${ }^{8}$

The poem is also an exemplification of Amiri Baraka's radical modernity thesis and Temple's notion of literary Sankofa, voicing as it does current events while simultaneously making references to an historical past. Allen does this by relating the current black diasporic experience of employment discrimination to the history of exploitation in the Atlantic slave trade:

is a long time wi knocking

an everytime yu slam the door

sey: no job

discrimination injustice

a feel the whip lick

an the same boat

the same boat

Oh Lawd Oh Lawd Oh Lawd eh ya. ${ }^{9}$

Afua Cooper takes a similar approach in her poem "Africa Wailin'," in which she links modern-day tensions between the black community and Toronto police to the brutality of enforcement during slavery:

... and see two peace car park

watchin In I

Ready fi caas shackles pon we again

chains roun wi neck

chains roun wi waists

chains round wi ankles

chains round wi wrist

an as wi fling rockstone

inna Babylon bone

while Africa is still wailin

wailin

wailin

wailin. $^{10}$

${ }^{8}$ Klive Walker, Dubwise: Reasoning from the Reggae Underground (Toronto: Insomniac, 2005): 164.

${ }^{9}$ Allen, Women Do This Every Day, 83.

${ }^{10}$ Afua Cooper, Copper Woman and Other Poems (Toronto: Natural Heritage, 2006): 70. 
The repetitive use of "wailin" here captures the past and present suffering and pain endured by the community; it also serves as an example of dub poetry's emphasis on sound and assonance, rather than simile and metaphor, to make meaning. In the same poem, Cooper also contextualizes the work of current artists and black-liberation figures by naming different regions of Africa and their deities and diasporic spiritual (reggae) elders:

... an we help each other as we begin dis passage

weak an tattered

cold and afraid

packed together like sardines in a tin

Lady Saw is embarkin

as Oshun

Burning Spear, di griot from Kangaba

Do you remember the days of slavery?

do you remember

Rita Marley an exiled priestess from Kumasi

will start a new world religion

an we love each other

we gentle wid each other

as we continue di journey"

"Africa Wailin'” also recaptures images of a Kingston dancehall scene and sets them in a downtown Toronto nightclub. While Cooper calls out popular reggae and dancehall acts in Jamaica, she also acknowledges Stereo-Prophet, a reggae and dancehall sound system originating in 1980 s Toronto:

Africa wailin

as Stereo-Prophet trow dung

inna downtown

at Tequila

an 300 sing as one

sing along wid the dj

sing along wid the singers

wid Sizzla an June Lodge

an Gregory, Tony Rebel,

I love you like fresh vegetable ${ }^{12}$

${ }^{11}$ Cooper, Copper Woman and Other Poems, 69. 
This re-imagining of the Jamaican dancehall landscape is an example of what Anthony Giddens calls de-territorialization, which he defines as the "'disembedding' (lifting out) of people and symbolic forms from the places we expect them to be." ${ }^{\prime \prime 3}$ Building on this thesis, Androutsopoulos and Scholz note that the potential endpoint of de-territorialization is "re-territorialisation, i.e., the integration of this cultural pattern into a new society."14 Both of these notions are helpful in mapping out how indigenous knowledges flow from one place to the next and function in diasporic sites, particularly as they foster the persistence of Jamaican local knowledges, or cultural continuity and retention, rather than focusing only on the rupture and fragmentation of culture as found in Stuart Hall's work. The concepts of de-territorialization and re-territorialization also trouble Gilroy's Black Atlantic thesis, which posits that the diasporic experience is chiefly predicated on responses to racialized capitalism and exchanges between various African diasporic cultures. In contrast, the frameworks offered by Gidden and by Androutsopoulos and Scholz allow us to consider not only how Afro-Caribbean (and other immigrant) artists respond to conditions and cultural exchanges within the diaspora, but also how they transform diasporic spaces by the importation of their indigenous cultures. We certainly see this dialogic flow between an African-Jamaican aesthetic and responses to local realities in Cooper's and Allen's works. Commenting on this continuity of culture, Klive Walker points out that many West Indians living outside the Caribbean "maintain an umbilical cord to Caribbean culture and in particular to the music of reggae and calypso."15 Walker's use of the term 'umbilical cord' here is telling, signifying as it does the strength of the bond that diasporic artists and writers retain with their place of origin.

Cooper's work is also significant for refraining from depicting black Caribbean people as victims. Rather, she embarks on a project of documenting the emancipation of diasporic Africans and reconstructing black self-love as functionally possible, thus disrupting mainstream Western notions of blackness.

\footnotetext{
${ }_{12}$ Cooper, Copper Woman and Other Poems, 69.

${ }_{13}$ Anthony Giddens, The Consequences of Modernity (Stanford CA: Stanford U P, 1990): 21.

${ }^{14}$ Jannis Androutsopoulos \& Arno Scholz, "Spaghetti Funk: Appropriations of Hip-Hop Culture and Rap Music in Europe," Popular Music and Society 26.4 (2003): 467.

${ }^{15}$ Walker, Dubwise: Reasoning from the Reggae Underground, 156.
} 
Her efforts in this regard echo Marson's blues poems and their insistence on, and celebration of, black beauty. They also contest the view, put forward by Beckwith and others, that Jamaican-based art is lacking in themes of love and beauty. Consider, for instance, the following lines from Cooper's "Africa Wailin'":

Woman in red, green, and gold weave an dread wid locks down to their feet women in shiny shiny clothes tight like rass an men in basic black wid nuff bling bling confess their love to each other... ${ }^{16}$

The celebratory mood that Cooper conveys here, an approach we also see in Allen's work, challenges the notion that Canadian dub poetry is only, or even primarily, concerned with protest and anger. Indeed, the poems are equally an expression of the everyday lives of African-Jamaicans in Canada.

One of the fundamental manifestations of an African-Jamaican aesthetic in dub poetry is its centering of orality, a 'transcriptive' style of écriture (designed for aural reception in the public arena) that has not always been understood, or indeed accepted, as part of the Western tradition of poetry (despite its 'respectable' presence in English dialect verse by poets such as Wordsworth). Allen has recounted how she and two other dub poets were denied membership in the Canadian League of Poets because they were not "real poets." ${ }^{17}$ Temple summarizes such discrimination as follows:

Black literature from formerly colonized regions of Africa and the Caribbean have all been challenged by eurocentric literary criticism that judges the

${ }^{16}$ Cooper, Copper Woman and Other Poems, 69.

${ }^{17}$ Lillian Allen, "De Dub: Renegades in a One Poem Town," This Magazine (December 1987January 1988): 14, as reported by Brenda Carr, “'Come Mek Wi Work Together': Community Witness and Social Agency in Lillian Allen's Dub Poetry," ARIEL: A Review of International English Literature 29.3 (July 1998): 14 (see also 11 on general prejudice against Jamaican English expression). Ironically, such limited views of literature are not the province of North America alone see, for instance, the poet Louise Bennett's original omission from the Jamaican literary canon on the basis of her not being a 'real writer'. 
literature's merit based on its appropriation of European literary genres, languages and aesthetics. ${ }^{18}$

Aware of this reality, Allen uses her poem "One Poem Town" to legitimize the artistic merit of vernacular orality. Using Jamaican creole, she draws upon 'cuss' style (known in the African-American tradition as signifyin') to counter European literary discourses that undervalue forms of neo-African literary culture and to display the complexity and richness of her verbal dexterity:

Hey! Hey! Hey!

this is a one poem town

this is a one poem town

ride in on your macramed verses

through barber green mind

keep it kool! kool! kool!

on the page

'cause, if you bring one in

any other way

we'll shoot you with metaphors

tie you cordless

hang you high in ironies

drop

a pun 'pon yu toe

run yu down, down down

and out of town

'cause, this is one poem town

and hey! What yu doing here anyway?

So done't come with no pling, ying, jing

ding something

calling it poetry

'cause this is a one poem town

and you're not here to stay?!

Are you? ${ }^{19}$

Allen is masterful here in her application of onomatopoeia and a vernacular voice to ridicule and ventriloquize the white Canadian voice that refuses to

\footnotetext{
${ }^{18}$ Temple, "Rescuing the Literary in Black Studies," 766.

19 Allen, Women Do This Every Day, 117.
} 
accept her dub aesthetic as a legitimate form of literature and literacy. Allen's poetic skill is also assumed to have cast a lyrical spell on her antagonist (the white establishment) by leaving him/her silent and defeated. This is another important feature of the 'cuss style' of verbal exchange, also evident in early Jamaican reggae toasting and modern dancehall and hip-hop culture.

Brathwaite points out that the "noise" of dub poetry is integral to its meaning, keeping faith as it does with African oral performance heritage..$^{20}$ In this respect, "One Poem Town" reads no differently than the Guyanese poet John Agard's "Listen Mr. Oxford Don," which also uses the oral vernacular to showcase linguistic dexterity and, below the surface, to counter pernicious stereotypes of black criminality. Agard, an immigrant living in England, achieves this via a brilliantly figurative assault on the Oxford Dictionary:

Me not no Oxford don

me a simple immigrant

from Clapham Common

I didn't graduate

I immigrate

But listen Mr Oxford don

I'm a man on de run

and a man on de run

is a dangerous one

I ent have no gun

I ent have no knife

but mugging de Queen's English

is the story of my life

I don't need no axe

to split/ up yu syntax

I don't need no hammer

to mash/ up yu grammar

I warning you Mr. Oxford don

I'm a wanted man

${ }^{20}$ Edward Kamau Brathwaite, "English in the Caribbean: Notes on Nation Language and Poetry," in English Literature: Opening Up the Canon, ed. Leslie A. Fiedler \& Houston A. Baker Jr. (Baltimore M D: Johns Hopkins U P, 1981): 24. 
and a wanted man

is a dangerous one. ${ }^{21}$

By subverting language in an empowering way, here via a linguistic form of verbal duelling, both Allen and Agard engage in "black backtalk," ${ }^{22}$ which creative act is a further demonstration of Dei's argument that an anti-colonial framework is flexible, in part, because of how it permits diverse indigenous knowledges to be in dialogue with other local cultures rather than only with the dominant (eurocentric) discourse. ${ }^{23}$ In this way, "black backtalk" is harnessed alongside orality, nation language, and other local cultural vehicles to express diverse poetic forms.

Religion and spirituality are also key elements in the work of Allen and Cooper. In "Riddim and Hardtimes," for example, Allen's persona takes on the voice of a Rastafarian prophet to protest police shootings of black youth in general and Albert Johnson ${ }^{24}$ in particular. Allen also embeds connotations of African drumming and reggae in her poem, thereby further strengthening the text's spiritual ties with Rastafarianism:

An' him chucks on some Riddim

an' yu hear him say

riddim an' hardtimes

riddim an's hardtimes

music a prance

dance inna head

drumbeat roll

hot like lead....

roots wid a Reggae resistance. ${ }^{25}$

However, Allen does not limit herself to one religious framework. In "Psychic at Twelve," for instance, she applies African spirituality to an account of the near-

${ }^{21}$ John Agard, Mangoes and Bullets (London: Serpent's Tail, 1990): 44.

${ }^{22}$ Houston A. Baker, Jr., Modernism and the Harlem Renaissance (Chicago: U of Chicago P, 1987): 21-24.

${ }^{23}$ Dei, Rethinking the Role of Indigenous Knowledges in the Academy, 12.

${ }^{24}$ Albert Johnson was a black man who was shot by two Metro Toronto police officers at a rooming house in 1979. The shooting death of Johnson led to mass protest against a string of policing shootings that involved black males in Toronto.

${ }^{25}$ Allen, Women Do This Every Day, 63-64. 
death experience of the persona's grandmother. The poem contests the Christian understanding of death as an event where the soul, departing the body, ascends to heaven:

The day my grandmother was pronounced dead

for the second time

I was by her side

beads of garli $\mathrm{c}^{26}$ crystals and I

her room unsmiling... ${ }^{27}$

The persona goes on to describe the grandmother's body dancing vivaciously around the fire in obedience with a neo-African observance of funeral rites. This, too, is contrary to Western Christianity where the body is often cast away after death. The persona develops this alternative belief-system:

my spirit took flight

clutching hers

an interlocutory curvature of the psyche

her soul urging a push

I caught her on a breeze

held her close

till she fought her way back..$^{28}$

Like Allen, Cooper draws heavily on African-centred religions and spiritual ancestry in her work. She also takes up, albeit to a lesser extent, black Christianity, as illustrated, in its language and imagery, by the poem "Upper Room," which is is inspired by the gospel singing of Mahalia Jackson (in one of her bestknown songs, "In the Upper Room"):

Baptism of fire

baptism of fire

with your voice Mahalia

${ }^{26}$ Duppies, or spirits, were an integral part of the Jamaican belief system and the fear of incurring their rage led to the creation of a number of rituals to ward them off. For example, babies and little children were considered to be more at risk, so a bit of caul was stitched in a small piece of black ribbon coupled with garlic, asafoetida, and other highly scented drugs and attached around the children's neck; Brian Moore \& Michele A. Johnson, Neither Led Nor Driven: Contesting British Cultural Imperialism in Jamaica, 1865-1920 (Kingston, Jamaica: U of the West Indies P, 2004): 51-95.

${ }^{27}$ Allen, Women Do This Every Day, 32.

${ }^{28}$ Women Do This Every Day, 32. 
as you take me to the Upper Room to meet my Lord

Halleulujah!

you crown me with your chants

as we commune

as we converse with the holy spirit

you crown me with your chants

and I spin, yes

I stumble and then

I rise

my mouth opens and my tongue speaks in a language... ${ }^{29}$

Most of Cooper's poems focus on African-based spirituality without the syncretism of "Upper Room" with its response to Christian invocation of God coupled with Afro-Baptist physical possession and glossolalia. In the dream poem "She Dance," for example, she infuses the text with Vodou imagery to invoke the persona's spirit possession through dance:

lawd look di way

she dance

she dance

she dance

she hold up her head

square her shoulders

all rigid-like

den get loose

an start to shake

lawd look di way she dance

she dance

she dance she dance

she dance

she dance.... ${ }^{30}$

Here, Cooper's text, with its anaphoric 'drumming' structure, recalls Marson's poem "Gettin' de Spirit," in which religious possession is dramatized and its mesmerizing power presented as an avenue to liberation and a spiritual path back to Africa. In Marson's case, the narrator, spiritually overwhelmed, shouts

\footnotetext{
${ }^{29}$ Afua Cooper, Memories Have Tongues (Toronto: Sister Vision, 1982): 101.

${ }^{30}$ Cooper, Memories Have Tongues, 99.
} 
to God in creole to free herself, while in Cooper's poem the persona uses dance as a means to spiritual and cultural liberation: ${ }^{3^{1}}$

but now har body contorting

she ben ovah inna pin

lawd she must be dying

but look she come

to life agen and dance

and dance

chile is fah pickney is you

who you belong to

who initiate you into di rites of voodoo

where you learn fi dance so

fi dance so

fi dance so

lawd loo di way you dance... ${ }^{32}$

Cooper's poem "Stepping To Da Music/Sic" (for Bob Marley) does not reference any specific religious doctrine, but it again employs the spirituality of dance to explore (re)connections to African identity and the past. She draws on Bob Marley's reggae song "No Trouble" to reinforce the notion of West African cultures as a powerful grounding for liberation from the sorrows of oppression. Indeed, for Cooper, salvation is imagined as a return to an "ancient [African] God" as she transforms the literary space of the poem into a sacred danced space:

Bob

you make me move in an ancient way

in an ancient way that my feet never forgot

you make my feet, body

do things I never thought was possible

you made me do old world dance

Dahomey dance

you make me the priestess

in pure and sacred way

${ }^{31}$ I take up these two poems, "She Dance" and Gettin de Spirit," later (Chapter 4) in a feminist context.

${ }^{32}$ Cooper, Memories Have Tongues, 100. 
we don't need no more sorrow

and my body moves slowly, my arms uplifted

I am offering sacrifice to my ancient God. ${ }^{33}$

The prominence of dance, often in relation to African spirituality, is indeed woven throughout Cooper's and Allen's bodies of work. They present dance as both an act of resistance and a spontaneous eruption of life and joy.

Ingrid Reneau, in her exploration of ringshout, a traditional dance performed throughout much of the US South and the Caribbean. posits that the dance is fundamentally a "ritual of remembrance. ${ }^{34}$ She notes that many African diasporic writers borrow from a ringshout aesthetic to explore the potential for renewal inherent in making connections to an ancestral past. She offers Toni Morrison's Beloved and Paule Marshall's Praisesong for the Widow as examples of writing that uses a ringshout trope as a means of clearing the way for a remembrance of Africa. ${ }^{35}$ In a similar vein, Brathwaite's poem "Limbo" ${ }^{36}$ evinces another type of dance in response to the cultural disconnection and oppression of the diasporic experience. In the poem, the main character "recovers the true significance of another Afro-Caribbean folk ritual, the limbo dance," which "originated [as] a necessary therapy after the experience of the cramped conditions between the slave ship decks of the middle passage." ${ }^{37}$ In discussing Brathwaite's work, Charles Pollard notes that such a view suggests that dance is a powerful site of cultural transmission precisely because it was not as easily or thoroughly suppressed through colonialism as were religion and language were: "Brathwaite is again drawn to cultural practice - the physical performance of limbo dance - as the most likely place to recover an Afro Caribbean cultural connection. ${ }^{38}$

${ }^{33}$ Cooper, Copper Woman and Other Poems, 98.

${ }^{34}$ Reneau, "Dancing the 'Clearing' in African Diaspora Narratives," ii.

${ }_{35}$ Another, more recent example is the Caribbean-Canadian fiction writer Nalo Hopkinson's science-fiction fantasy Brown Girl in the Ring (New York: Warner, 1998).

${ }^{36}$ Edward Brathwaite, The Arrivants: A New World Trilogy (London: Oxford U P, 1981): 274.

${ }^{37}$ Charles W. Pollard, New World Modernisms: T.S. Eliot, Derek Walcott, and Kamau Brathwaite (Charlottesville: UP of Virginia, 2004): 71.

${ }^{38}$ Pollard, New World Modernisms, 72. 
Lillian Allen seems to agree. In her poem "Limbo Dancer," the persona engages in dance to free herself from the shackles of slavery and to call up memories of Africa:

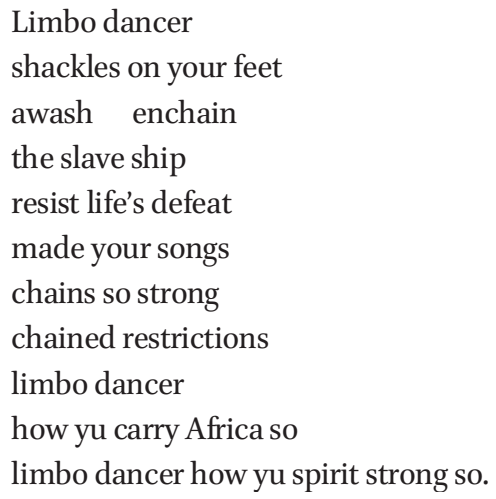

Additionally, Allen uses limbo in the poem to comment on the commoditizing of African diasporic culture to satisfy the tourist gaze:

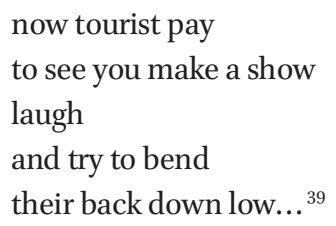

As Reneau notes, "dance remains one of the most crucial elements in the everyday life of African diaspora people," yet, with the dominance of eurocentric scholarly discourse, little attention has been devoted exclusively to the treatment of dance by African diasporic writers. ${ }^{40}$ Dance and many other AfroCaribbean performative phenomena, states Kene Igweonu, "are obvious parallels that exist between African and African Caribbean performance aesthetics which serve to indicate and uphold their shared identity and history." Igwenou goes on to suggest that these parallels mark the point

where the nostalgic longing for, and recognition of Africa as land of the forebears comes in as the dynamic incentive for the African Caribbean to engage with those residual aesthetics that connect them to their African past. ${ }^{41}$

\footnotetext{
${ }^{39}$ Allen, Women Do This Every Day, 47-48.

${ }^{40}$ Reneau, "Dancing the 'Clearing' in African Diaspora Narratives," 4.

${ }^{41}$ Kene Igweonu, "Interculturalism Revisited: Identity Construction in African and African-
} 
In a personal conversation with Afua Cooper on the links between dance and literature, she notes that, for African diasporic peoples, dance is philosophy. She recalls her childhood dance instructor beginning her classes with an explanation of dance as a celebration of the past, an honouring of the ancestors and a transmission of an African world-view. Cooper's comments are in line with Fanon's assertion that

any study of the colonial world should take into consideration the phenomena of dance and possession $[\ldots]$. The circle of the dance is a permissive circle: it protects and permits. ${ }^{42}$

The Jamaican dancehall artist Elephant Man puts it more succinctly: "Everybody dance an sweep dem weh" and "Dancing a Jamaica middle name." ${ }^{\text {"3 }}$ Indeed, the integration of dance by writers such as Cooper and Allen is an example of Sankofa; a literary paradigm scholars such as Temple employ to understand black literature and its engagement with the notion of a 'return' to Africa from the vantage point of the diaspora. ${ }^{44}$

Dance is just one element of the pan-African sensibility evoking racial and political consciousness in Cooper's and Allen's works. As noted previously, panAfricanism is often written off as essentialist in diasporic discourse; but, while hybridity is an important component of African diasporic social reality, to overemphasize this frame risks downplaying, or eurocentrically excluding altogether, other sociocultural, historical, and political factors that have been critical in the construction of African diasporic and subaltern reality. As the Jamaican literary scholar Norval Edwards points out, Paul Gilroy presents afrocentric nationalism (which he opposes) as the polar opposite of cultural syncretism (which he celebrates), but in doing so ignores cultural developments

Caribbean Performance," in Trends in Twenty-First Century African Theatre and Performance, ed. Kenechukwu Igweonu (Amsterdam \& New Yoek: Rodopi, 2011): 81.

${ }^{42}$ Fanon, The Wretched of the Earth, 57.

43 "Everybody dance an sweep dem weh," in "Dance N Sweep," rádiovol, http://services.radio .uol.com.br/\#/letras-e-musicas/elephant-man/dance-n-sweep/2173251; "Dancing a Jamaica middle name," in "Signal De Plane," Elephant Man Lyrics, http://www.azlyrics.com/lyrics/elephant man/signaldeplane.html (accessed 20 February 2015).

${ }^{44}$ Temple, "Rescuing the Literary in Black Studies," 781. 
such as Négritude, and I would add pan-Africanism, which, if in some ways essentialist, honour a wider African-based syncretism and hybridity. ${ }^{45}$

In a broader view of pan-African creative writing one can read beyond the essentialism of some of its poetry and fiction to recognize the inclusivity underpinning its nurturing of black cultural identities. As the sociologist St Clair Drake notes, pan-Africanism

consciously and deliberately attempts to create bonds of solidarity based upon a commonality of fate imposed by the trans-Atlantic slave trade and its aftermath. ${ }^{46}$

In a literary context, Temple posits that a pan-African paradigm "encourages readers to explore the mutual heritage, the points of divergence, and points of convergence between regions of Africa and the diaspora". ${ }^{47}$ One can see just such an effort in the works of Allen and Cooper. Both poets embrace pan-Africanism yet depart from essentializing black identities in their affirmation of the diversity of 'blackness' and re-imagining black women and their sexuality. ${ }^{48}$ Additionally, their work examines class and includes the experiences of other racialized groups who have also been affected by (neo)colonialism. Their literary creations are thus clearly located in their diasporic social reality and, while inclusive of local cultures, reflect the broader scope of hybrid and syncretized identities that Gilroy speaks of.

In "True Revolution," Afua Cooper laments the periodical lapse into passivity of black people in their struggle for liberation as evidenced by submission to neocolonial temptations (a rehearsal of the Rastafari condemnation of Western 'Babylon'):

No Kamau

there won't be a revolution because people have grown

complacent, accepting, and no longer have ideals

No Kamau

there won't be a revolution

45 Edwards, "Roots and Some Routes Not Taken," 29.

${ }^{46}$ St Clair Drake, "Diaspora Studies and Pan-Africanism," in Global Dimensions of the African Diaspora, ed. Joseph E. Harris (Washington D C: Howard U P, 1982): $35^{2}$.

47 Temple, Literary Pan-Africanism, 78.

${ }^{48}$ The discussion of black women and sexuality will be taken up in greater detail in the next chapter. 
because once again they have brought in the colonisers

(americans) this time

to whip the people into submission. ${ }^{49}$

Here Cooper addresses Kamau Brathwaite, whose writing also employed an African-centred aesthetic (nation language, reggae, jazz, West African drumming) to articulate the struggle for justice among people of African descent in the diaspora. Cooper goes on, in the same poem, to draw on African-Jamaican dance, Rasta chanting and nyabinghi drumming, and past historical leaders in her call for revolutionary change:

To dance to the martial chant

we need Far-I

binghi drums

we need ones with the spirit of Nanny, Tacky and Plato

to plan and stategise

to lay in wait and stick

at the enemy knowing fully well who he is..$^{50}$

Another significant feature of dub poetry is a sense of place as crucial to identity in new diasporic sites. One sees this in recurring themes of memories of a distant homeland juxtaposed with current experiences in the host country. Allen and Cooper take a differentiated approach to the notion, promoted by some diasporic scholars, that 'settler' preoccupation with homeland is often, and necessarily, nostalgic and romanticizing. They go beyond merely idealizing their country of birth and offer social commentary on the home left behind. In "Condition Critical," for instance, Allen responds with dismay to chronic poverty in Jamaica, commenting on the unrelenting effects of neo-colonialism, the unfulfilled promises of post-colonial political leaders, and the disillusionment of Jamaica's high hopes upon independence from Britain:

Soh that's why...

Dem a mash it down inna Jamaica

Dem a add it up down inna Jamaica

Dem sey dem tired of trying to buy the country

From America and the IMF pact

\footnotetext{
${ }^{49}$ Cooper, Copper Woman and Other Poems, 71.

${ }^{50}$ Copper Woman and OtherPoems, 72.
} 
A little friendly debt with an open end

It feel like the ball and chain game again. ${ }^{51}$

In a similar vein, Cooper's poem "Christopher Columbus" recalls a grade-school history lesson where she was fallaciously taught that Columbus 'discovered' Jamaica:

As a little girl in grade four

the teacher would take us to see

this statue and we would attempt to draw-etch-

this conqueror of new land

we were made to repeat

(and every child would know this)

Christopher Columbus discovered Jamaica in 1494

with his three ships

the Nina

Pinta

and Santa Maria. ${ }^{52}$

While Cooper stares at Columbus's statue "remembering a beautiful land," she also recalls the tears of her ancestors and the "graves and spirits of a vanquished people" (the Tainos, the original inhabitants of the island) and "marvels today that we still honour our conqueror." ${ }^{\text {33 }}$ Clearly, the poem stands as a poignant critique of colonial education in Jamaica.

In contrast, Cooper, in "And I Remember," instead of adopting an overtly political tone in relation to place, reminisces on her childhood memory of roaming the fields and hills of rural Jamaica. ${ }^{54}$ While one might interpret such a poem as nostalgic, the text works to metaphorically juxtapose the writer's childhood of freedom and belonging in Jamaica with her current life in Canada, which is marked by marginalization and un-belonging. Thus, her memories function as a means of surviving the displacement and racial discrimination that mark her life in Canada. Such approaches are evidence of Allen's and Cooper's commitment to using place in a way that critically ties their diasporic experiences to their native country.

\footnotetext{
${ }^{51}$ Allen, Women Do This Every Day, 111.

${ }^{52}$ Cooper, Memories Have Tongues, 27.

${ }_{53}$ Memories Have Tongues, 28.

${ }^{54}$ Memories Have Tongues, 15.
} 


\section{Jamaican Dub Poetry as Political Activism: The London Scene}

The UK dub poetry tradition aptly illustrates the way the artform has been employed to comment on, and reflect, local diasporic themes and challenges. Like their Canadian counterparts, British Jamaican dub poets speak eloquently about issues critical to black communities in the UK. As Linton Kwesi Johnson (LKJ) so pointedly puts it, "From the very beginning I saw myself as giving voice to, and documenting, the experience of my generation. ${ }^{55}$ This experience includes struggling against racial discrimination, asserting belonging and citizenship, and affirming a distinctly black British Caribbean voice. At the same time, black British dub poets have remained responsive to transatlantic cultural currents. The following section will examine some British-based AfricanJamaican dub poetry - the work of LKJ and, to a lesser extent, that of Benjamin Zephaniah - to examine how it adapts a Western model, transforming it by integrating an African-Jamaican aesthetic.

The racial discrimination faced by black Caribbean people in the UK was particularly virulent and violent, including the burning down of black homes and businesses, and murders in black and South Asian neighbourhoods between the 1950s and the late 1970s, acts committed primarily by members of white fascist groups. In response, many British dub poets have echoed the physical violence waged against black communities. In his poem "Fite Dem Back," for instance, LKJ speaks in a much more hostile tone than that characteristically employed by Allen, Cooper, and earlier writers such as McKay and Marson. Alternating between Jamaican Patwa and a cockney accent, to represent the racist National Front, LKJ chants:

we gonna smash their brains in cause they aint' go nofink in 'em... we gonna smash their brains in cause they aint' go nofink in 'em... some a dem say dema niggah haytah an' some a dem say dem a black beatah some a dem say dem a black stabah... ${ }^{56}$

${ }^{55}$ Burt Caesar, "Linton Kwesi Johnson talks to Burt Caesar at Sparkside Studios, Brixton, London, 11 June 1996," Critical Quarterly 38.4 (December 1996): 67.

${ }^{56}$ Linton Kwesi Johnson, Inglan Is A Bitch (London: Race Today Publications, 1980): 20. 
Although LKJ focuses on violence against black communities, "Fite Dem Back" also comments on attacks upon South Asians: "an some a dem say dem a paki bashah. ${ }^{57}$ LKJ, like many of his dub poet peers, uses a pan-Africanist discourse to discuss the oppression of, and links with, other oppressed (non-black) groups. Walter Rodney's later works did the same, applying pan-African tenets to include other ethnic and racialized groups who were also scarred by colonialism and the capitalist system.

Not all of LKJ's poems take such a violent tone, although resisting oppression is a continual theme. In "Inglan Is A Bitch," he uses the persona of an aged and overworked Caribbean immigrant to voice opposition to labour exploitation and marginalization. Speaking of long work hours, poor pay, and high taxes, LKJ dubs:

dem

have a

lickle factri up inna Brackly

inna disya factri all dem ahu is pack crackery

fi di laas fifteen years get mi laybah. ${ }^{8}$

Here LKJ's words echo those spoken by McKay's Quashie, naming as they do the experience of working under plantation and colonial-like conditions but this time in the context of the metropolis of London. As LKJ notes, "dere's is no escapin' it / Ingland is a Bitch /dere's no runnin' whey fram it." ${ }^{59}$ Though the poem ends with a rhetorical question - "is whey wi a goh dhu 'bout it?" - I infer that the intended response is not for Caribbean people to return home and abandon their struggles in England but instead a call to assert their rightful place as black British citizens. Indeed, LKJ points to two choices: accepting the social and economic realities of living in England - as the persona in the poem puts it, "y'u haffi know how fi survive in it" - or openly challenging the racism of the system, as LKJ has done.

As with other dub poets, language plays a central role in the poetry of LKJ. While his earlier poems were written primarily in Standard English, he soon

\footnotetext{
${ }^{57}$ Johnson, Inglan Is A Bitch, 20.

${ }^{58}$ Linton Kwesi Johnson, Tings an Times: Selected Poems (Newcastle upon Tyne: Bloodaxe, 1991): 14 .

${ }^{59}$ Johnson, Tings an Times, 17.
} 
began to use Jamaican orthography more consistently. In addition, he became critical of British Caribbean poets who relied on African-American vernacular to express black British concerns. ${ }^{60}$ In the opening verse of the epistolary poem "Sonny's Lettah," LKJ uses Jamaican creole to relate the alienation and racial prejudice of England. This is similar to what Marson does in her poem "Quashie Comes to London." Quashie, however, also describes the pleasures of London (its theatres, music halls, and fine restaurants) to his friends back home, while LKJ's subject, Sonny, fails to find any kindness in his situation. Writing to his mother from a Brixton prison, Sonny describes the police harassment faced by black British men in general (the notorious SUS or stop-and-search law), and his brother in particular. His main reason for writing is to inform her of the murder he committed while defending his brother from an altercation with police following an unwarranted arrest:

Mama

Mek Ah tell y'u whey dem dhu to Jim

Mama, mek Ah tell y'u whey dem dhu to him

Dem t'ump him in him belly

an' it turn to jelly

dem lick him pan im back

an' him rib get pap

dem lick him pan him he'd

but it tuff like l'ed

Dem kick him in him seed

an it started to bleed

Mama

let me tell you how they handle Jim

let me tell you how they handled Jim...

The latter part of the poem relies even more heavily on Patwa to graphically describe the brutal beating of Sonny's brother and eventual murder of the policeman:

Mama,

Ah jus could'n stan-up deh

an' noh dhu not'n

Soh mi jook one in im eye

${ }^{60}$ Caesar, "Linton Kwesi Johnson talks to Burt Caesar," 66. 


\begin{abstract}
An' him started to cry
mi t'ump one in him mout'

an him stated to shut

mi kick one pan him shin

an him started to spin

mi t'ump him pon im chin

an' him drop pan a bin

an crash

an de'd. ${ }^{61}$
\end{abstract}

The poem's protestation of the speaker's innocence is a simultaneous assertion of his agency and a plea for the need to protect his human rights and those of his "brother." Like Allen's "Riddim and Hardtimes," "Sonny's Lettah" becomes part of a larger public discourse by aligning with community members and activists to politicize police brutality against black youth and to attract media and government attention.

In Black Like Who, Rinaldo Walcott argues that police relations tend to be one of the most pressing issues for diasporic black communities; a site in which the dominant culture enforces its position. ${ }^{62}$ It is not surprising, then, that this theme is often taken up by black cultural producers. In Louise Bennett's "South Parade Peddler," which thematizes the universal Jamaican practice of higglering (one of the chief domains in which black women asserted their autonomy after slavery), an illegal street vendor tries to prevent police from confiscating her goods:

One police man dah come, but me

Dah try get one more sale.

Shoeslace! Tootpase! Buy quick, no, sah!

Yuh waan me go a jail? ${ }^{63}$

This theme is further reflected in many of the poems already examined in above: McKay's "Heart of the Constab," in which a policeman expresses

\footnotetext{
${ }^{61}$ Johnson, Tings an Times, 26.

${ }^{62}$ Walcott, Black Like Who? Writing Black Canada, 85.

${ }^{63}$ Bennett, Jamaica Labrish, 27; Selected Poems, 84. Carolyn Cooper provides acute observations on the folk personality of Jamaican women in "'That Cunny Jamma Oman': The Female Sensibility in the Poetry of Louise Bennett," Bulletin of Eastern Caribbean Affairs (Barbados) 11.1 (March-April 1985): 13-27.
} 
remorse about joining the force because of its repressive nature toward working-class black people; Cooper's "Africa Wailin'," which explores tension between the police and black communities in Toronto; and Allen's "Riddim and Hardtimes," protesting the police shooting of the African Canadian Albert Johnson. In each of the above examples, an African-Jamaican aesthetic, especially language, is instrumental in voicing the perspectives of poor, workingclass black people in their troubled relations with the police.

In contrast to most of the other diasporic writers examined here, LKJ does not integrate black spirituality or African-centred religion into his work. In fact, in "Reality Poem" he blames religion as the core cause of "divishan" within black communities and urges poets to

mek wi leggo relijan

dis is di age af decishan

so mek wi leggo divishan

dis is age af reality

soh mek wi leggo mitalagy

dis is di age af science an' teknalagy. ${ }^{64}$

This is in contrast to the Jamaican Canadian dub poet Michael St George, whose work provides an example of African mythology as a valuable means of surviving white supremacy. In his poem "Ancestral Way," he dubs:

Dis dis disregard that myth

Thinking technology and computer

Alone will solve it

Where is the combination

Of ancestral walk

Ancestral talk wisdom

Vibes and spirituality

Linking you back to the roots

Linking to eternity

As eternity links you

To your tracks of yesterday

And the day before

Determine today and tomorrow. ${ }^{65}$

\footnotetext{
${ }^{64}$ Johnson, Tings an Times, 30.

${ }^{65}$ Michael St George, Night Spin (Lethbridge, Alberta: Professional Informatics, 2001): 61-62.
} 
LKJ does not see the relevance of returning to an African past (a "mitalagy") in order to be liberated from colonial cultures. He prefers, instead, to address the current situation by focusing on concrete and material solutions that will assist in black emancipation. Nevertheless, it should be noted that although LKJ does not himself espouse black spirituality as a central motif he does recognize its significance in the lives of African diasporic peoples. In "If I woz a Tap Natch," for instance, he alludes to Kumina, Vodou (and other African-derived beliefsystems), calypsoes, and "slave songs" as sources of inspiration:

Ah woudah write a poem

Soh rude

An rootsy

An subsersive

Dat it mek di goon poet

Tun white wid envy

Like a candhumble/voodoo/kumina chant

A ole time calypso or a slave song

Dat get ban

But fram granny

Rite

Dung

To

Gran

Pickney. ${ }^{66}$

It may be the case that Marxist politics influenced LKJ's and McKay's attitudes toward religion. Both writers were active members of communist organizations. As the historian Dudley Randall points out, Marxist ideology presented black writers with a compelling alternative to the Anglo-capitalist system. He notes that even those who did not join the Communist Party were "sympathetic toward it and its policy of non-discrimination"; for those who did join, they "did not give up their struggle for Negro rights but regarded it as part of the struggle for the rights of man everywhere. ${ }^{n 7}$ However, there was no consensus

\footnotetext{
${ }^{66}$ Linton Kwesi Johnson, Mi Revalueshanary Fren: Selected Poems (New York: Ausable, 2006): 93.

${ }^{67}$ Dudley Randall, "The Black Aesthetic in the Thirties, Forties and Fifties," in Modern Black Poets: A Collection of Critical Essays, ed. Donald B. Gibson (Englewood Cliffs NJ: Prentice-Hall, 1973): 36 .
} 
on the efficacy of the communist model in re-imagining black struggles. Josaphat Kubayanda, for instance, argues that communist ideology ultimately

tends to 'globalize' the social and material aspects of experiences, [and that] in doing so it ignores the reality of color stigma in the Black experience, a reality that is firmly rooted in the black psych of the diaspora. ${ }^{68}$

Aimé Césaire abandoned communism for these very reasons, as he did not believe it could speak to the cultural realities and nuances of black experiences. ${ }^{69}$

Though LKJ maintains his scepticism towards religion, in a recent online B BC interview he acknowledges the complexity of religion in a colonial context. He recalls discovering how religious doctrine, such as liberation theology, served as a revolutionary tool in Latin America and that many of the slave revolts in Jamaica had religious leaders. ${ }^{70} \mathrm{He}$ also notes that, as for many Caribbean writers, the Bible was his first exposure to literature and that "it has become part of the oral tradition in the Caribbean.."71 Among his childhood memories are reciting Bible verses for his grandmother and at Sunday school. While LKJ does not lose sight of the fact that Christianity was used by European elites to justify and organize the enslavement and dehumanization of people of African descent, he also allows that many blacks in the New World reframed doctrines of Christianity to support liberation struggles and slave revolts.

Further, LKJ does employ a Rastafari aesthetic in his texts. Even here, however, he does not take up Rastafarian religious discourse as many of his peers did, nor does he include'back to Africa' rhetoric. Instead, he keeps his focus on reggae rhythms, black consciousness, and Rasta speech, which for him are an integral part of Jamaican oral culture. ${ }^{72}$ His Patwa poem "Di Anfinish Revalueshan" illustrates how he espouses Rastafari culture to call black communities to mobilize for liberation and political consciousness:

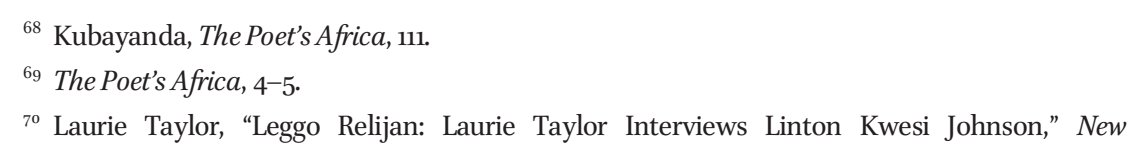
Humanist (Spring 2003), http://newhumanist.org.uk/583/leggo-relijan-laurie-taylor-interviewslinton-kwesi -johnson-by-laurie-taylor-spring-2003 (accessed 7 February 2010).

${ }^{71}$ Caesar, "Linton Kwesi Johnson talks to Burt Caesar," 64-65.

72 "Linton Kwesi Johnson talks to Burt Caesar," 64. 
di time goin come agen

yu can bet

wen wi a goh march awn agen

yu hear mi fren

moblise wi woman an wi fren dem agen

even di pickney dem a golb jine een...

soh mi a beg yu mistah man

please come out a yu shell

yu cyan dwell inna di pass

d alas fi evah yu know mi bredda...

far freedom is nat no idealagy

freedom is human necessity. ${ }^{73}$

Ironically, here he cautions communities to move beyond an African "paas" and yet embraces the Rastafari sign, "Zion," taken from the Bible ${ }^{74}$ to symbolize black people's return to a just homeland. He then uses a biblical reference to contextualize a promised land for people of African descent: "but wi still noh bil di new Jerusalem / yet." ${ }^{75}$

LKJ's inclusion of Rastafari philosophy carries with it the same pan-African sensibility as his Afro-Canadian dub compatriots. Although much of his work centres on the black British experience, his call for black liberation and consciousness extended beyond the UK to include the wider African diaspora. In "Reggae for Radni," for example, he pays tribute to Walter Rodney by metaphorically paralleling the death of the pan-Africanist Caribbean leader with the lost dream of black liberation around the world. The poem employs repetition to emphasize his regret at Rodney's unfulfilled pan-African vision:

Yu noh si how di cloud

dem jus come satta pan mi dream

sit upon mi dream

like a daak silk screen

a daak silk screen

owevah di vizshan I ad seen

${ }^{73}$ Johnson, Tings an Times, 61-62.

${ }^{74}$ Rastafarians adopted the Hebrew Bible language of Jewish exile, complete with an apparent theology of return. Zion was used to refer to Ethiopia or the African continent.

${ }^{75}$ Johnson, Tings an Times, 61. 
di vizshan I ad seen

di vizshan I ad seen...

Yu noh si how mi dream

come get blown to smidahreen

blown to simidahreen

inna di miggle a di dream

di miggle a di dream

before di people dem come een

di people dem com een

di people dem come een... ${ }^{76}$

The text also calls to mind Cooper's poem "True Revolution," which likewise refers to African liberation activists and expresses disappointment in the failure to-date of realizing their visions of justice for blacks in the diaspora.

Although LKJ's cultural reference points are clearly Jamaican, he does not idealize the country. Echoing Allen's "Critical Condition," LKJ's "Reggae fi Dada," written after his father's death and a visit to Jamaica, takes stock of the bitter social and economic conditions of post-slavery Jamaica:

Di pain nite an day

Di strench af decay

di glaring sights

di guarded affluence

di arrogant voice

cowl eyes af kantemp

di mackin symbals af independence

mi neva have noh time

wen mi reach

fi see noh sunny beach

wen mi reach

jus people live in shack

people livin back-to-back

mongst cackroach an rat

mongst dirt and dizeez

subjek to terrorist attack

political intrique

${ }^{76}$ Tings an Times, 32. 
kanstant grief

ah noh sigh af relief. ${ }^{77}$

LKJ offers an analysis of these conditions in poems such as "Problems" and "Song of Blood," which speak explicitly to the neo-colonialism plaguing his native country. By not identifying Jamaica, or any other particular Caribbean island in these poems, he speaks to the shared colonial history of the region. In contrast to Afua Cooper, LKJ's memories of Jamaica seem to provide little solace for the displacement and racial prejudice he experiences in England.

I turn now to the dub poet Benjamin Zephaniah. A contemporary of LKJ's, Zephaniah had a slightly different trajectory into the art form. Most significantly, Zephaniah was born and raised in England (by Jamaican and Barbadian parents), although he did spend a few years of his early childhood in Jamaica. As well, although there are only five years between them, Zephaniah did not begin writing until a decade later than LKJ. Despite these differences, the two poets share much in common. Zephaniah's work also takes up the black British experience, including relations with the police, systemic discrimination and the Caribbean immigrant experience. And, he draws on the indigenous culture of Jamaica, especially creole themes and symbols, reggae rhythms and Rastafarian religion. In fact, Zephaniah has some interesting reflections on his use of language. While he utilizes Patwa in some of his poems to capture the voices of his persona, he more frequently relies on Standard English. Commenting on this, Zephaniah notes that he was born in England and English is therefore the only language he has ever known. ${ }^{78} \mathrm{He}$ also points out that English itself "is a mixture of other languages" (online interview). Besides, he argues, even if he had been born and grown up in Jamaica, English would have still been his first language because "they beat all traces of our Africanness out of us" (online interview). While I understand the point Zephaniah is trying to make, I believe

77 Johnson, Tings an Times, 35 .

${ }^{78}$ Like Marson's "Little Brown Girl” who speaks "English as though it belonged to [her]" (Moth and the Star, 13), Zephaniah subversively claims English as his own native tongue. Marson and Zephaniah affirms George Lamming's claim that "English does not belong to the Englishman. It belongs to a lot of people who do a lot of things with it"; Lamming, in Reinhard Sander \& Ian Munro, "The Making of a Writer - a Conversation with George Lamming" (1972), in The Routledge Reader in Caribbean Literature, ed. Alison Donnell \& Sarah Lawson Welsh (London: Routledge, 1996): 272. 
his comments fail to take into account the African retention that has remained woven into the Jamaican cultural fabric, in general, and into the language in particular. Nonetheless, I do not disagree with his comment that English borrows from many linguistic groups:

English does not just belong to the English, it borrows from the tongues of many people and so there is nothing wrong with many people speaking it. It is a highly flexible language, which is why some of the best usage of English is now being done by Asian and African people. We use English in our own rhythms. ${ }^{79}$

Zephaniah's views on language stand in opposition to those of a writer like Ngũgĩ wa Thiong'o, who deliberately sets English aside in favour of indigenous African languages, an act he sees as literary decolonization. ${ }^{80}$ Zephaniah, however, complicates this idea of either English or not, by insisting on the malleability of the language, which allows it to be reimagined and radicalized. $\mathrm{He}$ uses reggae rhythms with 'Standard' English, for instance, and while the vocabulary and syntax remain largely unchanged, he still manages to innovate by the insertion of a Black English sensibility. This is, of course, an approach taken by many writers from former colonial territories who attempt to offer counter narratives through their manipulation of dominant languages. The Guadeloupean writer Simone Schwarz-Bart, for example, uses standard French while infusing it with a Kreyol cadence, and Allen's "One Poem Town" and Agard's "Listen Mr. Oxford Don" both creatively subvert English as a means to destabilize linguistic hierarchy.

In addition to Zephaniah's creative use of English, he employs Rastafarian political and spiritual discourse. In his early poem "Dread John Counsel," for instance, he uses biblical allusions from his Rastafari faith as a basis for commenting on the injustice of the British judicial and political systems:

In this land my brothers and some sisters fight me down

Therefore in the dark place and the jailhouse I am found

But I have a weapon that shall burn the enemy

${ }^{79}$ Ahmede Hussain, "In Conversation with Benjamin Zephaniah," Black and Gray Blog, http://ahmedehussain.blogspot.ca/2007/o1/in-conversation-with-benjamin-zephaniah.html (accessed 16 September 2011).

${ }^{80}$ Ngugi wa Thiong'o, Decolonising the Mind: The Politics of Language in African Literature (London: James Currey \& Portsmouth NH: Heinemann Educational, 1986): 71-72. 
And it has a fallout that shall rule equality,

The court is revolutionary the righteous ones shall stand

And in the tabernacle there doth play a reggae band

There is no House of Commons and everyone is high

And the kingdom is governed by a upfull one called I,

But I am here in exile far away from home

Still in this sick capacity I will not use their comb

We are not fussy 'bout being British free

The kingdom's international a kingsdom we can see,

They will never give us what we really earn

Come our liberation and see the table turns

Still this is me in exile far away from home

Still recruiting soldiers to break this modern Rome. ${ }^{81}$

One can see how "Dread John Counsel" performs on a number of levels, beginning with the title's play on the Rastafarian term "dread" to place emphasis on the severity of the injustices black people face in England and to write in a Rastafarian presence, thus signalling protest at European cultural and political imposition. Zephaniah also disrupts the tabernacle space (a sacred space used to house the Ark of God) with the sounds of a "reggae band." This links the suffering of diasporic black people and their hopes of a return to a promised land [i.e. Africa] with that of the Israelites. Later in the poem, Zephanian upsets the "House of Commons" with the burning of the holy herb (marijuana) and defiant refusal to use "their comb" on his dreadlocks. ${ }^{82}$ Here Zephaniah's reference to "their comb" is symbolic of his moral resistance, based on Leviticus 19:27, which speaks of Bablyon and its many instruments of oppression. It also echoes the Rastafarian DJ Toaster Dillinger's declaration in his 1970 recording "Natty Dread a the General" that "Natty go a Rome an broke two comb" and he refuses to adhere to their policies and doctrines. ${ }^{{ }^{8}}$

Similarly, Zephaniah's "Dread Eyesight," uses Rastafari discourse to radicalize the Bible by transposing familiar imagery from the Book of Revelations. The Four Horsemen, for instance, are re-imagined as the "four dreadlocks." And as

\footnotetext{
${ }^{81}$ Benjamin Zephaniah, The Dread Affair: Collected Poems (London: Arena, 1985): 54-55.

${ }^{82}$ Zephaniah, The Dread Affair, 54 .

${ }^{83}$ Dillinger, "Natty Dread a the General," YouTube (13 August 2012), http://www.youtube.com / watch?v=bg-wFikEYcM (accessed 20 July 2014).
} 
in Afua Cooper's spiritual poems, Zephaniah places Rastafari elders as central figures who will lead the way forward by sharing wisdom and inspiration:

We are the children of the slaves and the victims of oppression, so from the land in which we removed to let us shout with a voice that vibrates with dread and say to them men of earth, it is JAH RASTAFARI who giveth wisdom and understanding, for the land of Ethiopia has lifted up her heart, and the power of the trinity has opened the gates of Zion for the spirits of children who lived earth lives of great tribulation to enter therein. ${ }^{84}$

While Zephaniah's use of Rastafarian philosophy differs from LKJ's in his reliance on religious/biblical imagery (which Johnson rejects), both poets are nevertheless similary engaged in using Rastafarian symbolism to envision a promised land free of racial oppression.

\section{Forging Community}

As the four dub poets I review in this chapter demonstrate, diasporic points of origin can, and do, function as necessary anchors in negotiating new spaces. Indeed, as these poets reflect on their double diasporic experiences from Africa and the Caribbean, they comment on the conditions of Afro-Caribbean migrants in Canada and Britain while at the same time re-deploying AfricanJamaican aesthetic forms. Their poems shuttle between Canada, England, the Caribbean, and an 'imagined' Africa, thus confirming Temple's assertion that diasporic literature "embodies not only ideas about back-to-Africa"

but also ideas of the associated voyages people of African descent have made to, from, and between regions of the diaspora in their quests to find home or to make significant connections to their African identities. ${ }^{85}$

Even LKJ, who dismisses a return to Africa as romantic, concedes that his literary works do have African cultural elements, mediated as they are through the African-Caribbean culture that is "part of my historical heritage and part of my cultural roots." 86

\footnotetext{
${ }^{84}$ Zephaniah, The Dread Affair, 81.

${ }^{85}$ Temple, "Rescuing the Literary in Black Studies," 780-81.

${ }^{86}$ Jason Gross, "Interview with Linton Kwesi Johnson," Perfect Sound Forever: Online Music Magazine (1997), http://www.furious.com/perfect/lkj.html (accessed 20 September 2011).
} 
Interestingly, Paul Gilroy's more recent considerations of the diaspora also show movement away from an "obsession with origin, purity, and invariant sameness," and the notion that cultural flows are only uni-directional. ${ }^{87}$ The dub poets of Canada and the UK reflect this more expansive understanding of the diasporic experience. While they certainly write with a forward gaze that is from and within their diasporic locations, they also look to the past and their continuing link to West Africa as a source of cultural origin and strength, and in doing so create a thoroughly contemporary literary form. This intertwining of the here and there, away and origin, diaspora and Africa, provides these writers and their readers with a map of survival. Indeed, the activism of dub aesthetics has helped to strengthen bonds of social cohesion in local communities of Afro-Caribbean origin in Toronto and London, thus promoting dub poets as "agents of society." I I use this term to describe such authors because, even while they write from their individual persona(s), they retain the collective voice of the African Caribbean struggle for justice, as we hear in the protests of McKay's Quashie; Marson's stone-breakers, and LKJ's Sonny. As social activists, these writers give voice to the experience of black folks, thus acting as agents of liberation to help decolonize the minds of a people emerging from colonial rule. They do this in part by transforming and indigenizing European models of literature, thus creating new literary forms and coherent cultural identities. Dei argues that decolonization involves the examination and deconstructing of colonization and is, therefore, necessarily the pursuit of resistance politics. ${ }^{89}$ The dub poets of Canada and the U K certainly represent such a politics.

In the introduction to her dub anthology, Afua Cooper reflects on the influence community and culture have had on her writing..$^{90}$ In an interview with Kwame Dawes, she explains how she sees the dub aesthetic as drawing on her Jamaican culture and her diasporic realities, and how black communities provide essential support:

\footnotetext{
${ }^{87}$ Tommy Lott, “'Black Cultural Politics': An Interview with Paul Gilroy,” Found Object 4 (Fall 1994): $56-57$.

${ }^{88}$ Brathwaite, "The African Presence in Caribbean Literature," 116.

${ }^{89}$ Dei, Rethinking the Role of Indigenous Knowledges in the Academy, 25.

${ }^{90}$ Afua Cooper, "Introduction" to Utterances and Incantations: Women, Poetry and Dub, ed. Cooper (Toronto: Sister Vision, 1999).
} 
I am a displaced person and I feel displaced - I come from Jamaica or the Caribbean and the experience shaped me. Those people from whom I come, that sensibility which I have, that is like the course, the feeding ground - and then you are sort of hurled, you are shot as from a rocket into different areas and spaces. What do you do with that? I don't know what I would do if I was living in Toronto and there were no black people here. Maybe I wouldn't write. It would be a problem. ${ }^{91}$

The need for community that Cooper articulates helps us understand not only the ways in which African-Jamaican identity and diasporic experiences inform these writer's works but also how they can function as models of preserving cultural and historical memory and negotiating complex social identities in Canada, the UK and other diasporic locations. LKJ expresses a similar desire for community engagement when he affirms the need to use his writing to voice and record black British experiences. ${ }^{92}$ By drawing on a shared sociohistorical past, transporting indigenous Caribbean and African knowledges, and speaking to their specific socio-political environment, dub poets have played a crucial role in establishing the meaning of black communities and identity in diasporic spaces. Equally significant, many of these writers recognize their new diasporic space as home; in LKJ's words "dere's is no escapin'." Allen also reflects on her early years as a dub poet:

Well it became very clear to me once I returned that I had to put my roots down and do what comes out of the African tradition - put down my roots and create for myself a new world. This place in Canada was my new world. ${ }^{93}$

Although their works borrow from, and interact with, the European canon, their texts clearly reveal continuity and repurposing of an Afro-Jamaica aesthetic to challenge and transform European literary models, chronicle the struggles of Afro-Caribbean peoples, and nurture African cultural values in new locations.

${ }^{91}$ Kwame Dawes, Talk Yuh Talk: Interviews with Anglophone Caribbean Poets (Charlottesville: UP of Virginia, 2001): 222.

${ }_{92}$ Burton, Afro-Creole: Power, Opposition and Play in the Caribbean, 67.

${ }_{93}$ Allen, Women Do This Every Day, 304. 



\section{4 \\ - Gendering Dub Culture Across Diaspora - \\ Jamaican Female Dub Poets in Canada and England}

fro-Caribiean wOMEn DUB POETS have long incorporated
feminist aesthetics into their work, thereby bringing a unique per-
spective to dub culture. Not surprisingly, then, and following in the tradition of Una Marson and Louise Bennett, the Jamaican Canadian dub poets Afua Cooper, Ahdri Zhina Mandiela, and Lillian Allen all employ an AfricanJamaican aesthetic to articulate the social conditions of black women in Africa and the diaspora and to call for opposition to patriarchal systems of oppression and black male dominance in the private sphere. This feminist discourse in dub poetry is particularly highlighted in Canada because Allen, Cooper, and Mandiela have been so instrumental to dub culture in that country. While I focus primarily on these three artists in this chapter, I also include some reflections on the work of Jean 'Binta' Breeze ${ }^{1}$ of the UK to provide a comparative analysis of how these writers utilize local Jamaican cultures to articulate black female experience.

While this chapter takes up race, class, and gender by female dub poets, this is not to suggest that earlier (as well as current) Jamaican creative writers have not also worked with these themes. However, it is important to note that, historically, dub poetry has been dominated by a male perspective and has focused thematically on race and class issues. This is a result of dub poetry's strong black-nationalist and pan-Africanist ties as both philosophies have tended to overlook intersections of gender and race in their framing of political

\footnotetext{
${ }^{1}$ Although 'Binta' Breeze often distances herself from dub poetry, I include her work because some of her poems clearly experiment with a dub aesthetic.
} 
and social transformation. Dub poetry was also influenced by its relationship to the male-dominated reggae industry. In contrast, for female dub artists racial and gender oppression were not viewed as mutually exclusive. Roberta Timothy describes this approach "as an umbrella practice connecting resistance to intersectional oppression," and notes that "African/black feminism is a tool of anti-colonialism that can support black resistance." ${ }^{2}$ The insertion of a feminist aesthetic was also a response to the reality of white male patriarchy in diasporic locations. As Lillian Allen asserts,

Being woman and a black at every moment in my life, I felt the need for a new vision of the world that included not only black people and working-class people's rights, but also the full and equal participation of women. So it was imperative that the fight be carried on, on this front also. ${ }^{3}$

Allen's comment speaks to her interest in addressing the intersecting factors of gender, race, and class in black women's lives, an approach that challenges the traditionally male-dominated narratives of pan-Africanist discourse.

The focus of this section is to uncover how African-Jamaican women dub poets write from different geo-social locations than their male counterparts as they attempt to negotiate their identity. Such an approach moves beyond European and US feminist analyses, which less often centre the intersectionality of gender, race, and class in eurocentric constructions of African diasporic peoples. I am also interested in how these dub poets employ an African-Jamaican aesthetic in a uniquely woman-centred way, including the primacy of an indigenous mode that draws Jamaican oral and folk culture. Since anti-colonialism is intrinsically tied to resistance and privileges oppositional discourses, it is useful to employ an anti-colonial feminist lens to deepen understanding of the continuity of indigenous African-Jamaican local culture and knowledges and a black literary aesthetic.

\section{Dub Foremothers}

As noted above, the works of the earlier writers Una Marson and Louise Bennett paved the way for female dub poets and their interweaving of an AfricanJamaican aesthetic with feminist discourse. Marson's work as a feminist and

2 Timothy, "Resistance Education," 79-80.

3 Allen, Women Do This Every Day, 18. 
cultural activist was not separate from her literary career. She wrote from a black female perspective, as seen in her poems (e.g., "Cinema Eyes" and "The Stone Breakers") and plays (Pocomania and At What Price), and I believe she can be read as Jamaica's first feminist writer. Surprisingly, in the preface to her book Women Do This Every Day, Lillian Allen does not mention Marson as one of the "outstanding" Jamaican literary figures of the past. She does, however, acknowledge Louise Bennett, who, like Marson, inserts a feminist sensibility into Jamaican literature by focusing "especially [on] rural women and poorer women of the city." ${ }^{\prime 4}$ Building on Marson's legacy, Bennett wrote entirely in Jamaican Patwa and drew on other forms of African-Jamaican orality (such as riddles and Anancy stories) to explore Afro- indigenous culture from a female perspective. Carolyn Cooper uses Bennett's poem "Jamaican Oman," along with other poems, to mark "the genesis of an indigenous feminist ideology" in Jamaica, which, she argues, pre-dates the more recent women's movement of Western societies. ${ }^{5}$

Dub poets themselves are well aware of the debt owed to foremothers like Bennett. There is a strong sense of female community informing the work of women dub poets in the diaspora. Lillian Allen's and Afua Cooper's poems often pay tribute to female figures in their lives along with "sheroes" from Jamaica, continental Africa, and the wider African diaspora. In "Tribute to Miss Lou," for instance, Allen honours Bennett for her efforts in legitimizing Jamaican Patwa in writing and performance. When Allen professes, "Pred out yuself Miss Lou / Lawd, yu mek we heart pound soh," she celebrates the work of a woman whose poetry captures Jamaica's cultural and linguistic richness, resulting in a distinct literary form. ${ }^{6}$ Referencing Bennett's popular children's programme 'Ring Ding', Allen dramatizes dance, music, and black religious performances to represent the vitality of the Jamaican language in the works of Bennett:

Get up

dance clap

sweat pon de ground

${ }^{4}$ Lillian Allen, in Utterances and Incantations: Women, Poetry and Dub, ed. Afua Cooper (Toronto: Sister Vision, 1999): 46.

${ }^{5}$ Cooper, Noises in the Blood, 48.

${ }^{6}$ Allen, Women Do This Every Day, 43. 
tambourine

sing a ring ding

sing a ring ding.

The poem not only reveals the vitality of the local Jamaican language, but also its versatility in expressing the multiple layers of an African-Jamaican cultural aesthetic.

\section{Black Feminism}

Both Allen and Cooper uncover the daily realities of black women and their struggle for social transformation and justice. Many of their poems challenge a Western feminist framework that fails to adequately take into account racial and class oppression. And contrary to notions that black feminist discourse emerges solely from the USA, Allen and Cooper and their female dub compatriots are inclusive of Caribbean diasporic feminist histories. In their poems, such as Allen's "I Fight Back," these women articulate a critique of racism similar to that found in LKJ's "Fite Dem Back" and "Inglan Is A Bitch," but do so from a female viewpoint. To highlight the labour exploitation of people of African descent, both women turn to the lives of black domestic workers in Canada. Cooper's and Allen's poems capture the stories covered in Silenced, a seminal work on Caribbean domestic workers by the Jamaican Canadian Makeda Silvera. ${ }^{8}$ Silvera's book, like the poems examined in this chapter, offers oral testimonies of the poor working conditions and everyday struggles of the Afro-Caribbean female working class. By centering black female narratives, Silvera, like these poets, empowers black female voices and disrupts the myth of Canada as a welcoming haven for immigrants. In this way, the silencing referred in Silvera's title is broken.

Allen's "I Fight Back" speaks specifically to the female immigrant experience, describing the long working hours, separation from children, and racial stereotyping domestic workers endure. Her use of the Patwa term 'backra' points to the parallels between current economic exploitation and plantation slavery, thereby revealing a radical modernity and literary Sankofa:

\footnotetext{
${ }^{7}$ Allen, Women Do This Every Day, 44.

${ }^{8}$ Makeda Silvera, Silenced: Talks with Working-Class Caribbean Women about their Lives and Struggles as Domestic Workers in Canada (Toronto: Sister Vision, 1983).
} 


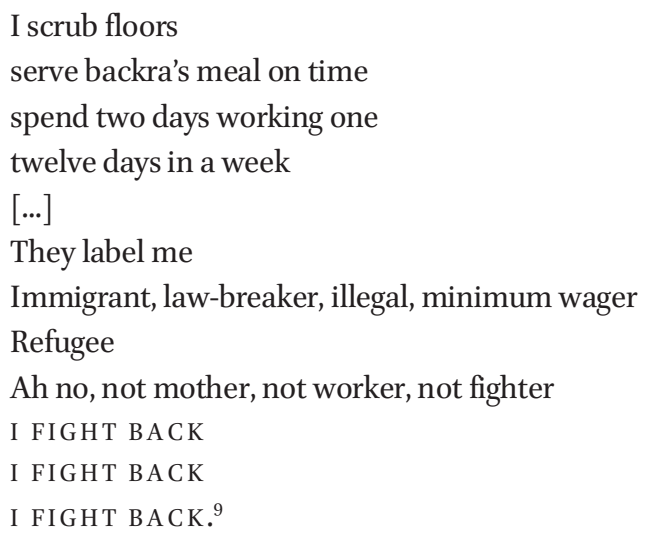

This poem serves effectively to contest the notion of Canada as a land of opportunity and reveals the particular difficulties faced by female immigrants from regions in the global South, like the Caribbean, who must often take lowpaying jobs in order to survive, creating what Himani Bannerji calls "feminized poverty" and "race-gendered class forms of criminalization and exclusion."10 The poem also offers a strong critique of how the labelling of racialized women as "immigrant" and "illegal" have further underwritten exclusionary practices that serve to push them to the margins of society.

Cooper also takes up the work experience of Afro-Caribbean women, as seen in her prose poem "Oh Canada," in which the female persona gives an account of alienation and struggle to adjust to the inhospitable climate. As she walks through an inner-city part of Toronto on a cold winter's day, she has flashbacks of her native Jamaica: "Regent Park reminded her of / Tivoli / jungle / Dunkirk / same square boxes with tiny inside."11 This geographical mapping of Jamaica onto Toronto suggests similarly disenfranchised communities. The persona goes on to speak about her job as a housekeeper and how she is overworked:

VII

the missis told her that her duties were

light housekeeping

${ }_{9}^{9}$ Allen, Women Do This Every Day, 139-40.

${ }^{10}$ Himani Bannerji, Dark Side of the Nation: Essays on Multiculturalism, Nationalism and Gender (Toronto: Canadian Scholars Press, 2000): 29-39.

"Cooper, Memories Have Tongues, 44. 


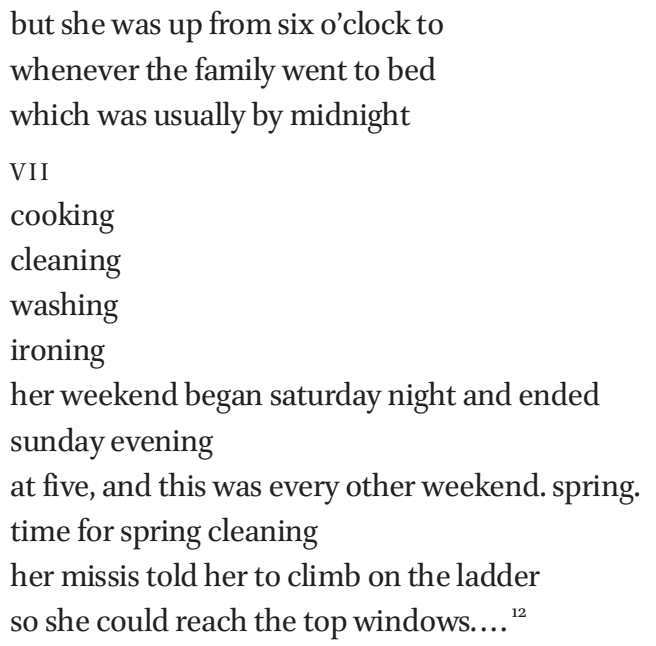

The poem acknowledges the ways white Canadian women are often implicated in upholding patriarchal structures when those structures serve to maintain their own interests above those of racialized women. This kind of acknowledgement is often absent from the critique of mainstream feminism, so that Cooper is advancing a dialogue about a black feminist poetics that might have meaning in a Canadian context. The poem closes with the persona's aunt advising her that "if you want good yuh nose haffi run /you haffi suck salt thru wooden spoon," referencing two Jamaican proverbs, both of which advise that hard work is necessary to achieve your goals. ${ }^{13}$ In a Jamaican context, these proverbs would simply be pointing out the need for hard work, but in the specific diasporic context, they take on new meaning. Despite the challenges black women face in cities like Toronto, the proverbs call them to assert their agency in order to create ways in which to navigate the racist and sexist societies in which they live.

In "Black Ooman," Ahdri Zhina Mandiela, another prominent figure on the Canadian dub scene, pays homage to the black women's community in Toronto. The poem also addresses the labour exploitation of immigrant black women and implicates black male oppression of women. Written entirely in Jamaican Patwa and inflected with reggae rhythms, the voices in the poem

\footnotetext{
${ }^{12}$ Cooper, Memories Have Tongues, 45.

${ }^{13}$ Memories Have Tongues, 46.
} 
confront their various oppressors to speak of the abuse they endure under a racist and sexist system:

if evvy day pure strife

only bring more wrawt

like a shawp blade knife

ah cut inna wih awt

always ah struggle fih wih life. ${ }^{14}$

In a similar, albeit more subtle tone, Jean 'Binta' Breeze's "Ordinary Mawning" depicts a woman performing her regular household tasks while reflecting on the trials and tribulations of being an unemployed single mother in England. At the back of her situation is the tension between personal responsibility for her children and stifled regret at being burdened by them, between the choices she must make every day to get by and the temptation to relent, to sacrifice the burden and pride of responsibility to (as in blues and soul texts) 'take him back'. The poem circles round and back to the diurnal pleasure and pain of the mornings of her life.

no

it wasn't de day dat start out bad

wasn't even pre $\mathrm{m} \mathrm{t}$

or post $\mathrm{m} \mathrm{t}$

was jus anadda ordinary get up

get de children ready fi school

mawning

anadda what to cook fah dinna dis evening

mawning

anadda wish me never did breed but Lawd

mi love dem mawning

jus anadda wanda if ah should a

tek up back wid dis man it would a

ease de situation mawning

[...]

was jus anadda

same way mawning

anadda clean up de mess

${ }^{14}$ Ahdri Zhina Mandiela, Speshal Rikwes (Toronto: Sister Vision, 1985): 40. 


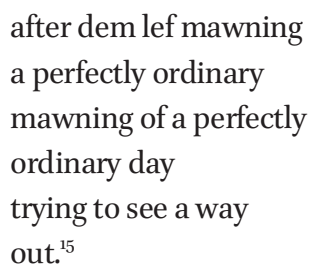

These female dub poets are also writing back to a tradition of black male writing in the Caribbean and the USA. Mandiela, for example, creolizes elements of Langston Hughes's popular poem "A Dream Deferred" and re-appropriates a line from the reggae master Bob Marley. This approach disrupts linguistic and literary hegemonies by re-purposing black male lyrics to voice the experiences of black women. Allen does the same when she adapts Bob Marley's lyrics in her poem "Rub a Dub Style Inna Regent Park" to advise AfroCaribbean immigrants in general, and black women in particular, to "forget yu troubles and dance."16 This conversation across gender is found in other genres too. The sociologist and feminist Althea Prince references the pan-Africanist C.L.R James and other notable black male scholars to help her uncover the everyday narratives of black women in their diasporic experiences and fiction. ${ }^{17}$

These poets also link specific experiences of gendered exploitation to the wider world, as when Breeze turns to South Africa and the Near East:

de sun did a shine same way
an a cool breeze
jus a brush een aff de sea
and de mawning news
was jus de same as ever
two shot dead
truck lick one
Israel
still a bruk up
Palestine

${ }^{15}$ Jean 'Binta' Breeze, Riddym Ravings and Other Poems (London: Race Today Publications, 1988): 49 .

${ }^{16}$ Allen, Women Do This Every Day, 83. Bob Marley's lyric comes from "Dem Belly Full (But We Hungry)" on the album Natty Dread (1978).

${ }^{17}$ Althea Prince, Being Black: Essays (Toronto: Insomniac, 2001). 
and South Africa still have de whole world han

twist back a dem. ${ }^{18}$

Her positioning of a global politics of unequal social relations is a demonstration of how women's concerns transcend the realm of personal complaint (the exposed flank for sexist male critics who might otherwise feel trempted 'to fault women for small-mindedness).

Further on in the same poem, she returns to socio-economic problems closer to home, using the supernatural elements of a Jamaican duppy (ghost) to comment on the high price of necessary commodities:

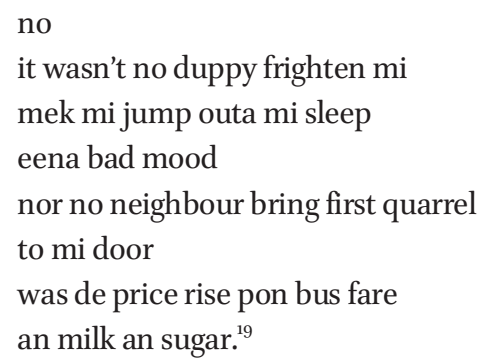

While certain aspects of African-Jamaican supernatural beliefs may be seen as discomfiting in the context of Christian spirituality, in this poem the persona better understands the referents and is more frightened of the social conditions she faces.

Similarly in Cooper's prose-poem "Negro Cemeteries," duppies are not seen as frightening. Rather, she employs a duppy figure in her poem to re-situate Afro-Canadians in their northern landscape. In an act of literary Sankofa. she relies on ancestors, Vodou deities, griots, and past historical leaders to unearth the discovery of slave and black settler burial sites in Upper and Lower Canada. The poem condemns urban development encroachment on black cemeteries and the blatant disregard for black life this represents:

ancestors are rolling over/from the fur-trader to the loyalist to the mariner from Dominica $[\ldots]$ Like Osiris, they burst from the earth $[\ldots]$ African skeletons shaking their dust from their bones $[. .$.$] Griots rising from their$

\footnotetext{
${ }^{18}$ Breeze, Riddym Ravings and Other Poems, 50.

${ }^{19}$ Riddym Ravings and Other Poems, 50.
} 
graves $[\ldots]$ Babalawos emerging from the storm [...] Papa Damballah hissed his displeasure at his unternment/Ogun squats ready with his iron cutlass. ${ }^{20}$

In invoking African deities and thus re-contextualizing Canada's history, Cooper re-integrates Afro-Canadians into the Canadian imaginary. The poem highlights the heretofore untold stories of a black Canadian woman:

And a woman named Dorinda sits on her tomb

a pipe smoking from between her lips

as she recites and recites and recites the stories of her many

passages the stories of her many transformations. ${ }^{21}$

Like 'Binta' Breeze in "Ordinary Mawning," Cooper moves beyond Canadian borders in her poem "Night Ease" to reflect on the narratives of women in the wider African diaspora. Here grandmothers represent the long enslavement and oppression of black women:

Grandmothers carried loads on their heads

babies in their arms

men in their hearts

cut sugarcane until their palm became calloused and bruised

their backs bent, necks stiff, spines misshapen and permanent hurt

lodged itself in their shoulders

Grandmas want to lay their burden down by the riverside. ${ }^{22}$

The grandmothers of this poem are understood as the nurturers of the black family who take on and epitomize the suffering of their people. Not until these grandmothers can lay their burden down will their people be free. Cooper also draws on facets of global black culture, closing the first strophe with an allusion to the African-American spiritual "Down by the Riverside" to illuminate the struggles of black women and their desire to break free of their 'sufferation'," and much of the second strophe is a reworking of Jamaican proverbs to emphasize the hardships black women have borne:

Grandmothers now lose all dem teeth

but in their mouths are dutty tuff stories

making bread outta stone stories

\footnotetext{
${ }^{20}$ Cooper, Copper Woman and Other Poems, 25.

${ }^{21}$ Copper Woman and Other Poems, 26.

${ }^{22}$ Copper Woman and Other Poems, 20.
} 
and stories of how they made it to the other side

of how time pass

an di children grow

an di men die

an the hurt ease

as evening brings with it a purple peace. ${ }^{23}$

Here the reconfigured proverb "their mouths are dutty tuff stories" (connecting thematically to Louise Bennett's poem "Dutty Tough") signifies orality and the role played by women in passing down stories of familial indomitability.

\section{Sexual Politics and Black Motherhood}

While I have noted multiple links between earlier black diasporic writers and contemporary Canadian women dub poets, one area of significant difference is the inclusion by dub poets of an open discourse on sexual politics and holding patriarchy accountable for their subalternity. In "Nellie Belly Swelly," Lillian Allen focuses on a teenage girl who is raped and impregnated by her stepfather and then hidden away until the baby is born. Employing the metaphor of planting a garden, Allen does not shy away from confronting troubling issues of sexual violence in black communities:

Nellie was thirteen

don't care 'bout no fellow

growing in the garden

among wild flowers

she Mumma she dig \& plant

nurtures her sod

tends her rose bush

in the garden pod

lust leap the garden fence

pluck the rose bud

Bruk ina the stem

oh no please no

was no self defence

oh no please

without pretence

${ }^{23}$ Copper Woman and Other Poems, 20. 
offered no defence

to a little girl called Nellie

Although Nellie's childhood innocence can never be regained, by the end of the poem she is reborn as a radical feminist:

She mustered an army within her

strengthened her defence

and mined the garden fence

no band made a roll

skies didn't part

for this new dawn

in fact, nothing heralded it

when this feminist was born. ${ }^{24}$

Noteworthy here is the shift from a tightly subjective personal focus couched in creole to formalization through Standard English to convey Nellie's awakening through trauma into determined objectivity. Although she was criticized by some black community members for poems such as this, for Allen the poem was crucial for its voicing of the too-often silenced sexual violence against black women. Such gender-based problems internal to the family were seen as compromising black identity and the larger struggle against racial inequality. ${ }^{25}$

Mandiela's poem "Ooman Git Up" similarly delves into diasporic sexual politics. Her female persona brings to light some of the daily domestic struggles of being a housewife, mother, and worker, including the unfair power (sexual) dynamic between women and their male partners:

Cause dem cum ome

an dem waan dih food

all cook an reddy

den pan top ah dat

dem waan yu mek

pickney stan steddy

yu wuk like auss

\footnotetext{
${ }^{24}$ Allen, Women Do This Every Day, 25-27.

${ }^{25}$ The quintessential articulation of white male abuse of defenceless young black women is an oppressively detailed prose-poem (based on a racial-profiling incident) by the Trinidadian Canadian Claire Harris: see her "Policeman Cleared in Jaywalking Case," in Harris, Fables From the Women's Quarter (Stratford, Ontario: Williams-Wallace, 1984):37-41.
} 
day in

an day out

den dem waan yuh luv dem

evvy nite

tiad out. ${ }^{26}$

Mandiela goes on to encourage black women to liberate themselves from the sexist notion that they must be confined to the kitchen or bedroom, and to insist on taking control of their bodies by resisting forced motherhood: "ooman gittup / owtah dih bed / an from ovah dih stove / now / eekwal pay an birt kantrol. ${ }^{27}$ This insistence on the importance of self-empowerment can also be read in historical context as a reference to the slave era when black women, as mere chattels, were denied such rights. For instance, the line "dem waan yu mek pickney stan steddy" recalls how black women were used as 'breeding' factories to reproduce slave labour, while the comparison of overworked black women to horses in "yu wuk like auss" underscores the economic and labour exploitation of black women until the present day.

A topic of clear resonance for female dub poets is mothering. In "Rub a Dub Style Inna Regent Park," Allen provides insight into the ways black mothers are affected by the police harassment and racism their sons face:

Monday morning broke

news of a robbery

Pam mind went

couldn't hold the load

dem tek her to the station

a paddy wagon

screaming...

her Johnny got a gun

from an ex-policeman

Oh Lawd, Oh Lawd Oh Lawd eh ya

a wey dis ya society a do

to wi sons. ${ }^{28}$

\footnotetext{
${ }^{26}$ Mandiela, Speshal Rikwes, 38.

${ }^{27}$ Speshal Rikwes, 38 .

${ }^{28}$ Allen, Women Do This Every Day, 81.
} 
This poem echoes the reality that black women have historically borne the burden of community responsibility, something rarely acknowledged in blacknationalist discourse or mainstream feminism.

In "I Fight Back," Allen also speaks to the ways in which black women are denied the right to fully mother their children. In the poem, she points to the unjust working conditions of Caribbean domestic workers that affect their ability to care for their own children even as they devote their time to the care of white children:

Here I am in Canada

bringing up someone else's child

while someone else and me in absentee

bring up my own. ${ }^{29}$

The above strophe not only informs us of the rupturing of black families in the contemporary world, but recalls the slave era when African women served as wet-nurses for white infants. More broadly, the situation attested can be read as a reference to what the black feminist writer Patricia Hill Collins calls 'other mothering, ${ }^{30}$ a concept that challenges the narrow confines of the nuclear family by allowing for alternative constructs of mothering. In "My Father's Mother," Cooper cites the instrumental role her grandmother played as an 'other mother' who shared family and cultural history and provided comfort in the absence of her biological parents:

she brewed chocolate, made fried dumpling and saltfish

sat in the yard with us and told

stories about the strikes and riots

the birth of my sister in the 1951 storm

about one of our uncles who went

to help the Panama canal and never came back

of her husband who died

${ }^{29}$ Women Do This Every Day, 139.

${ }^{30}$ Collins defines the concept of other mothers thus: "Other mothers - women who assist blood mothers by sharing responsibilities - traditionally have been central to the institution of motherhood in Africa and African diasporic communities"; Collins, Black Feminist Thought: Knowledge, Consciousness and the Politics of Empowerment (New York \& London: Routledge, 2000): 178. 
so young..$^{31}$

The figure of the grandmother is a nurturing icon who, because of the conditions of migration and labour, has to step in as generational substitute to care for black children in the physical and emotional absence of their biological mothers.

As the title suggests, Cooper's poem "Aunts" also celebrates the 'other mothers' of the extended family: aunts tell you "things like the facts of life" and dispense advice: "if you want good yuh nose haffi run / you haffi suck salt thru wooden spoon." ${ }^{2}$ Allen's and Cooper's poems echo Collins's work on the centrality of women in African diasporic extended families and their significant role in keeping cultural traditions alive and providing support in surviving transplantation to diasporic locations where intersecting oppressions of race, class, and nation are a reality. ${ }^{33}$

Alternatively, Cooper's poems "Seven Children" and "For Christine and Iselena" move away from the 'other mother' concept to concentrate on the struggles and triumphs of single mothers. "Seven Children" tells the story of a courageous mother who escapes the brutality of slavery, freeing herself and seven children after the death of her husband: ${ }^{34}$

Ann marie knew that more would be sold

Ann marie knew that she had to be bold

So she took her seven remaining children

and lef massa

lef di plantation

lef di pain

lef di grief behind..$^{35}$

"For Christine and Iselena" provides a more contemporary account of a black single mother and the barriers that require her to "fight for daycare / fight for welfare" and "fight for the right to have and take care of your children." In the

\footnotetext{
${ }^{31}$ Cooper, Memories Have Tongues, 18.

${ }^{32}$ Cooper, Memories Have Tongues, 46.

${ }^{33}$ Collins, BlackFeminist Thought, 178.

${ }^{34}$ Under the laws of slavery, slaves were not permitted to marry . However, here Cooper chooses to legitimize the matrimony of the persona in "Seven Children," giving her the marital status of a widow rather than single mother.

${ }^{35}$ Cooper, Memories Have Tongues, 47.
} 
poem, Cooper insists that black single women should have the right to define themselves, as opposed to being defined by society. She resists and rejects the titles "working mother / superwoman / bitch / amazons," and affirms: "you did not want any particular title you just want to be. ${ }^{n 6}$

Breeze's poem "Atlantic Drift" deals in addition with the issue of transnational motherhood. The persona in the poem is separated from her children, who are still living in Jamaica. She expresses the loneliness of London and her longing to see her children again:

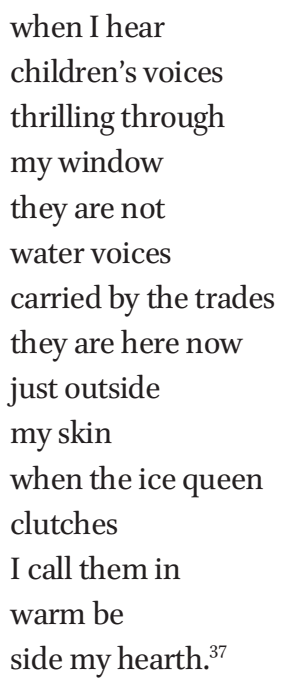

The "ice queen" character that Breeze alludes to in the poem can be read as a reference to both London's bad weather and the chill of separation and loneliness. Unlike the persona in Allen's "I Fight Back," who is separated from her children because of long work hours, Breeze's persona is separated from her children as a consequence of migration. Pierrette Hondagnew-Sotelo and Ernestine Avila define transnational motherhood as "how the meanings of motherhood are re-arranged to accommodate spatial and temporal separations. ${ }^{1{ }^{8}}$ Working with this definition in mind, Charmaine Crawford describes

\footnotetext{
${ }^{36}$ Cooper, Memories Have Tongues, $47-51$.

${ }^{37}$ Jean 'Binta' Breeze, Spring Cleaning: Poems (Reading: Virago, 1992): 37.

${ }^{38}$ Pierrette Hondagneu-Sotelo \& Ernestine Avila, “'I'm Here, but I'm There': The Meanings of Latina Transnational Motherhood" (1997), quoted in Charmaine Crawford, "African-Caribbean
} 
the difficult choices many migrant women, when seeking work abroad, must make in leaving their children and families behind. In doing so, they are forced to find alternative childcare arrangements, to essentially "re-arrange motherchild relations in opposition to normative gender standards." ${ }^{39}$ The challenges of this situation are captured by Breeze's title - "Atlantic Drift" - which signals a growing distance between mother and child. It also evokes the history of past separation between family members caused by the transatlantic slave trade.

It is equally important to note that these poets write against the problematic image of mothering represented in black-nationalist male discourse, which typically presents black mothers as an embodiment of the motherland (Africa) and as a matriarchal figure of the black 'nation'. This representation idealizes and 'idol-izes' the fortitude of black women, making them a 'superwoman' icon (see, for instance, George Campbell's 1954 poem "History Makers"). There is a core truth in this image, given the spiritual emasculation of the black male under slavery and the removal, through split-up families, of paternal responsibility: the sole half-way stable factor was the mother. But a perverse corollary of this humiliation of the male was his assertion of forms of extreme masculinity that reified women sexually (as can be seen in the discourse of dub, dancehall, rap and hip-hop performance today). Such idealization thus ignores the multiple forms of gender inequality black women experience; "mother Africa is declared free, the mothers of Africa remained manifestly oppressed." ${ }^{m 0}$ Such oppression finds ample articulation in the poetry of Allen, Cooper, Mandiela, and Breeze, which recalls readers and audiences to hard realities and counteracts the false lulling of idealization.

Women dub poets also explore child-bearing as the empowering recovery of the black female body. In "Birth Poem," for example, Allen provides a vivid physical description of the experience of giving birth, employing Patwa and African-derived anaphora to capture this rite of passage:

An mi labour an mi labour and mi labour

Women, Diaspora and Transnationality," Canadian Woman Studies Journal/Cahiers de la femme canadienne 23.2 (Winter 2004): 101.

${ }^{39}$ Crawford, "African-Caribbean Women, Diaspora and Transnationality," 100.

${ }^{40}$ Elleke Boehmer, "Stories of Women and Mothers: Gender and Nationalism in the Early Fiction of Flora Nwapa," in Motherlands: Black Women's Writing from Africa, the Caribbean and South Asia, ed. Susheila Nasta (London: Women's Press, 1991): 7 . 
An mi labour an mi labour and mi labour

An mi bawl whai

An mi push an mi push an mi push

An mi push an mi push an mi push

AN MI PUSH

An baps she born

An it nice yu see

An she cute yu see

This little girl we call Anta. ${ }^{41}$

When "Birth Poem" is performed live, an event I have had the opportunity to witness, Allen gives an animated performance wherein her face is distorted and her body contorted to stress the pain and physicality of childbirth. Bellowing the Jamaican words "whai" and "baps" brings the poem to life, expressing both the vibrancy of the Jamaican language and childbirth itself. In "The Child Is Alive," a poem inspired by the birth scene in Haile Gerima's film Sankofa, Cooper also invokes the midwife Nanny of the Maroons. Drawing on African mythology, spirituality, dance, and traditional healing rituals, the poem shows the powerful blessing of childbirth as a connector between past and future:

And a niece of granny nanny

an akan woman, a woman who can see far,

a woman with the knowledge of herbs

a woman who works in the field, cutting cane

a woman who tells stories of magical animals, talking trees and

of fabled cities beneath mighty rivers

a woman was stolen from her village when she was 14

a woman who was raped on the slave ship by a white sailor

a who woman who flies to Africa when she sleeps. ${ }^{42}$

Mandiela takes a different approach to childbirth in her poem "Ooman Git Up," calling on black women to reclaim their bodies. Rejecting the notion that the value of a black woman's body should be solely in reproduction, the poet urges women to "gittup / owtah dih bed" and demand "eekwal pay an birt kantrol." ${ }^{43}$

\footnotetext{
${ }^{41}$ Lillian Allen, Riddim and Hardtimes (Toronto: Domestic Bliss, 1982): 23.

${ }^{42}$ Cooper, Copper Woman and Other Poems, 27.

${ }^{43}$ Mandiela, Speshal Rikwes, 38.
} 
The presence of childbirth as a literary theme in these narratives can be read as symbolic of the rebirth of black female identity. We see this in Allen's poem when Nellie, through the childbearing experience (although this results from a tragic event), is reborn with a radical, feminist consciousness, and then again when Cooper's Nanny safely delivers the infant godhead "Onyame, [who] take the spirit of the mother," ${ }^{\prime 4}$ and reunites the mother and her baby with the ancestors. For these women, the procreation of new generations allows them "to counter the fragmentation of time that is caused by the degradation of childbirth during slavery and by the slave owners' repudiation of history." ${ }^{m 5}$ One can see this reclamation of history in the links Cooper makes between Nanny, the midwife, and the mother:

This woman, this niece of granny Nanny, this ancient midwife

dances with the child, backward, forward, sideward

spins and joins her companions dancing

like the priestess she would have been

had not a slavers stolen her away

from her people

The woman dances

east

south

west

north

should the child up to the sky

blessings. ${ }^{46}$

These poems about childbirth and mothering reveal the complexity of black women's experiences, offering a kind of redemptive dignity and recuperation of maternal agency (without idealization) denied in the travails of slave history.

\section{Dance, Spirit, and Culture}

As indicated in Chapter 3, dance is often offered in African diasporic creative writing as a means of spiritual survival and connection to an ancestral past.

${ }^{44}$ Cooper, Copper Woman and Other Poems, 28.

${ }^{45}$ Madhu Dubey, Black Women Novelists and the Nationalist Aesthetic (Bloomington: Indiana UP, 1994): 78 .

${ }^{46}$ Cooper, Copper Woman and Other Poems, 28. 
This is true, too, of the works of female dub poets who invoke dance metatextually (in contexts that are either pragmatically or notionally dance-performative) to legitimize black women's experiences. Although male writers also use dance as a liberatory and cultural tool (a topic I consider in the next chapter), female writers take up dance in a unique way, focusing on the power of movement as a means of spirit possession, which allows them to break free of the gender oppression that has policed black women's bodies. Earlier examples of this approach can be seen in Marson's poem "Gettin' de Spirit" and her play Pocomania. Looking specifically at dub poetry, we can see how dance, as employed by Afua Cooper, not only reveals a continuous engagement with the past but also supposes a spirit possession closely tied with empowering female sensuality. In "She Dance," for example, Cooper captures her persona dancing, "her body rippling like a snake" and "undulating like waves / seductive as the sea / as she dance. ${ }^{27}$ As Neil Armstrong's foreword to Copper Woman explains, Cooper's work demonstrates her interest in "the divine feminine and her belief that sexuality can be intensely spiritual and therefore have healing potential." ${ }^{48}$

Dance as a path of reclamation of the black woman body is a theme also present in Breeze's writing. In "Dubwise," which is influenced by dancehall rhythms and dance moves, the persona does not experience spirit possession; however, explicit sexual language is used to present "the erotic gyrations of a dancehall diva as a ritualized dance between the sexes for control of the floor." ${ }^{\prime 49}$ Echoing Cooper's conflation of the dancing female body with the seductiveness of a snake, Breeze's words swirl on the page to imitate pelvic rotations to the beat of the music:

'cool an

deadly'

snake

lady

writhing

'roun

de worlie'

${ }^{47}$ Cooper, Memories Have Tongues, 99.

${ }^{48}$ Neil Armstrong, in Cooper, Copper Woman and Other Poems, 9.

${ }^{49}$ Jenny Sharpe, "Cartographies of Globalisation, Technologies of Gendered Subjectivities: The Dub Poetry of Jean 'Binta' Breeze," Gender \& History 15.3 (November 2003): 448. 


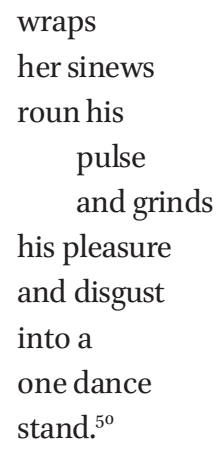

Interestingly, the use of snake imagery in these poems works against typical (Western) biblical readings which present the link between snakes, women, and sexuality as signs of evil and sin. In contrast, as John Kucich observes, "snakes were important symbols in African religions, signs of fertility and potent omens of [both] good and evil fortune. ${ }^{n 1}$ Charles Lippy, likewise drawing on Charles Joyner, notes, for instance, that "snake imagery pervades much voodoo ritual $[\ldots]$ the attribution of supernatural power to snakes has deep African roots. ${ }^{{ }^{22}}$ Elaborating on the multiple functions of snakes in African cultures, Asante and Nwadiora write:

Snake, Tree, and River figure together in some rituals. Some people in Benin believe that snakes are ancestors incarnate. Snake temples are found along the cost of Africa. Pythons are kept tame in temples and people will bow to them, put dust on their heads and salute them as fathers. The greatest crime is to kill a sacred python in some places. ${ }^{53}$

Like their male counterparts, women dub poets are significantly influenced by African-centred spirituality, cosmology, and folk wisdom. In his discussion of religion in Caribbean poetry, Gordon Collier explains:

$5^{50}$ Breeze, in Utterances and Incantations, ed. Cooper, 66.

${ }^{51}$ Charles Joyner, Down By the Riverside: A South Carolina Slave Community (Urbana: U of Illinois P, 1984): 145, as summarized in John J. Kucich, Ghostly Communion: Cross-Cultural Spiritualism in Nineteenth-Century American Literature (Hanover N H: UP of New England, 2004): 39.

$5^{2}$ Joyner, Down By the Riverside, 145, summarized in Charles Lippy, Being Religious, American Style: A History of Popular Religiosity in the United States (Westport C T: Greenwood, 1994): 90.

${ }^{53}$ Molefi Kete Asante \& Emeka Nwadiora, Spear Masters: An Introduction to African Religion (New York: UP of America, 2007): 9. 
religion and proto-religious belief systems (including mythology, superstition and legends) find expression primarily as confirmation of the social collective and its folkways. ${ }^{54}$

We see this in many of Cooper's poems invoking a strong spiritual presence, often embodied in women personae who bring strength, inspiration, and creative insight to their wider communities. The persona in "The Child Is Alive," for example, harnesses her African folk wisdom and tight bonds with African female deities to strengthen her role as midwife:

This woman, this niece of granny nanny

takes her cutlass an runs with the swiftness

of Sogolon Conde in her guise as buffalo woman ${ }^{55}$

This woman runs with her machete

an ancient chant rising from her throat

an ancient chant imploring the God and all the

spirits that attend women in childbirth to come

to her aid

She calls her companions, "Form a circle around the dead woman

breathe, breathe, deeply, give her breath

give her life. ${ }^{56}$

"Granny nanny" ties the priestess generationally to the legendary resistance heroine, Nanny of the Maroons, a figure who "remains alive in Jamaican folklore." ${ }^{57}$ Nanny was known to possess profound knowledge of herbal medicine and her leadership skills were attributed to Obeah, an African-centred beliefsystem. The ceremony's vodou-like lineaments, expressed in the symbolically wielded cutlass that binds resistance history to the present, also underscore the supportive female group communalism (the kumbla) involved. Nanny's legacy is invoked by the British Guyanese poet Grace Nichols, who affirms the need

${ }^{54}$ Gordon Collier, “"At the Gate of Cultures' of the New World: Religion, Mythology and Folk Belief in West Indian Poetry," in "And the Birds Began to Sing”: Religion and Literature in Post-Colonial Cultures, ed. Jamie Scott (Cross/Cultures 22; Amsterdam \& Atlanta G A : Rodopi, 1996): 227.

55 Sogolon Conde, mother of Emperor Sundiata Keita of the Empire of Mali (thirteenth century), was known for her ability to change form from human to animal; Oya, a goddess from the Nigerian pantheon, was also known to embody a buffalo at times (Cooper, Copper Woman, 28).

${ }^{5}$ Afua Cooper, Copper Woman and Other Poems, 27.

57 Carolyn Cooper, Noises in the Blood, 49. 
for new mythologies for black women that can break "the slave stereotypes of dumb victim of circumstances. ${ }^{n 5^{8}}$ In her own poem "Nanny," Nichols depicts Nanny as an "earth substance woman / of science / and black fire magic" with the ability to wreak pain on those who would seek to re-enslave the escaped Maroons. ${ }^{59}$ Nichols celebrates the majesty of Nanny's strength and mystical powers, describing her as "dressed in purple robes / bracelets of the enemy's teeth curled around your angles / in rings of ivory bones."

Breeze's poem "Warner" explores religion from a different angle, using biblical and Rastafarian imagery and the charged diction of Afro-Christian (Revivalist $\left.^{61}\right)$ spirituality. Here the folk figure of the warner woman walks about admonishing young mothers about the dangers of promiscuity and sin:

an de baby madda

clamp dung pone er stomach muscle

lack er foot tight

fah herod sword nah come een tonight

an river nah rush no more

Madda tek pickney by de han

An de cymbal dem start sing

She saying $i$

I come to bring warnin

fah de lawd Gad sat to tell you

dat de day of your sins is upon you

dat de day of tribulation is nigh

an de Lawd Gad... ${ }^{62}$

${ }^{5}$ Grace Nichols, "The Battle with Language," in Caribbean Women Writers: Essays from the First International Conference, ed. Selwyn R. Cudjoe (Wellesley M A: Calaloux, 1990): 288.

${ }^{59}$ Grace Nichols, "Nanny," in CAFRA Anthology of Caribbean Women's Poetry, ed. Ramabai Espinet (Trinidad \& Tobago: C AF R A, 1990): 269.

${ }^{60}$ Nichols, "Nanny," 269.

${ }^{61}$ This is an important and much-researched phenomenon. See, for example: George Eaton Simpson. "Jamaican Revivalist Cults," Social and Economic Studies 5.4 (December 1956): i-iv, 321442, and Simpson, "Revivalist and Other Cults," in Simpson, Black Religions in the New World (New York: Columbia U P, 1978): 111-17; Edward Seaga, "Revival Cults in Jamaica: Notes Towards a Sociology of Religion," Jamaica Journal 3.2 (1969): 3-13; Emanuela Guano, "Revival Zion: An Afro-Christian Religion in Jamaica," Anthropos 89 (1994): 517-28.

${ }^{62}$ Breeze, in Utterances and Incantations, ed. Cooper, 63-64. 
Breeze also evokes the presence of the "riva mumma," a Caribbean folktale figure derived from a West African deity and known for her spiritual power. ${ }^{63}$ The poem places emphasis on the potency of women and their importance in safely ushering the next generation into the community:

an de baby madda

wid de heart dem a push out troo er mout

more prick unda er skin fi flush er out

kean talk

fah if de riva mumma die if the de

if de riva mumma die

who shall cure the pain. ${ }^{64}$

The Jamaica poet Lorna Goodison playfully updates this mythical figure in her poem "River Mumma," by removing her from the confines of the river and reimagining her as a dancehall queen:

Mumma no longer wants to be guardian

of our waters. She wants to be Big Mumma,

dancehall queen of the greater Caribbean. ${ }^{65}$

In "Spring Cleaning," Breeze reworks a Biblical psalm with Jamaica Patwa by juxtaposing the religious narrative with a woman doing household chores:

yea though I walk

troo de valley of de

shadow of death

she opening de fridge

de cowl stapping her breath

for a motion. ${ }^{66}$

${ }^{63}$ The complex nexus of female clairvoyance, revivalist cults, maternity, and water symbolism is explored by Erna Brodber in Myal (London: New Beacon, 1988) and by Kei Miller in The Last Warner Woman (London: Weidenfeld \& Nicolson, 2010). These novels, and the tradition, are examined by Martina Urioste-Buschmann, "The Caribbean Allegory of Mami Wata: A Decolonial Reading of Gendered 'Plantation Memories' Within Contemporary Jamaican Fiction," in Essays: Exploring the Global Caribbean, ed. Susan Roberson (Newcastle upon Tyne: Cambridge Scholars, 2013): 2-19.

${ }^{64}$ Breeze, in Utterances and Incantations, ed. Cooper, 64.

${ }^{65}$ Lorna Goodison, Controlling the Silver (Urbana \& Chicago: U of Illinois P, 2005): 54.

${ }^{66}$ Breeze, Spring Cleaning: Poems, 71. 
Here Breeze echoes the poetic persona in Marson's "Gettin' de Spirit," who similarly communicates with God in Patwa. Breeze's creolization of the twentythird Psalm and feminization of its message is boldly innovative. The poem also takes on a powerful supernatural, duppy-like quality as the persona watches "all de dark spirits / departing wid de dus." ${ }^{67}$

Cooper's interest in keeping diverse spirits and legends alive throughout the New World and Africa is also evident in "Atabeya," which draws on the mythology of the Tainos, the aboriginal peoples of Jamaica:

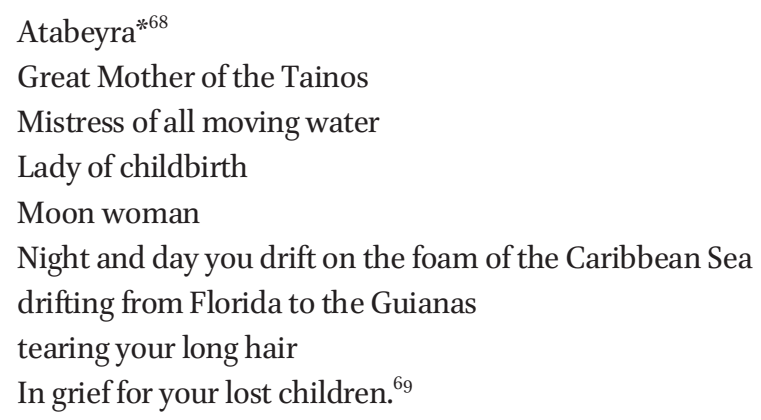

Cooper goes on to connect the spiritual and historical experiences of the aboriginal peoples with those of enslaved Africans. Painting on a broad canvas, she includes Egyptian mythological figures, African, Aboriginal, and Cuban deities, and Christian and Greek legends to explore her theme:
Atabeyra
you stand on the tallest peak of Seville mountains
straining your eyes over the vast expanse
of the Carib Sea looking for your lost children
Isis searching the world over the Osiris
Demeter mourning her loss of Persephone
Ishtar weeping for Tammuz
Mary grieving for Jesus
and Yemaya lamenting for Shango. ${ }^{70}$

${ }^{67}$ Spring Cleaning: Poems, 71.

68 "Atabeyra was the Greater Mother Goddess of the Taino people, one of the indigenous people that Columbus met when he arrived in the Caribbean" (Copper Woman, 37). While there is no evidence of the survival of Taino people in Jamaica after the eighteenth century, the Taino still form communities in Guyana and Dominica.

${ }^{69}$ Cooper, Copper Woman and Other Poems, 37. 
With its embrace of Caribbean powerful cultural configurations, the poem conveys the complexity of Jamaica's indigenous cultures that draw on the historical memory of indigenes, Europeans, and Africans. Cooper is mindful of the need not to replace one set of indigenous knowledges for another.

One can see how these writers promote positive female images to offer alternative constructs of black womanhood and to celebrate their role as the bearers of folk wisdom and African-centred spirituality and religion. In doing so, they challenge mainstream religious marginalization of the voices and presence of black women. Audre Lorde reflects on this in her response to the theologian Mary Daly's radical feminist book Gyn/Ecology: $:^{11}$

Where was Afrekete, Yemanje, Oyo and Mawulisa? Where are the warriorgoddess images of the Vodun, the Dohomeian Amazons and the warriorwomen of Dan? The oppression of women knows no ethnic nor racial boundaries, true, but that does not mean it is identical within those boundaries. Nor do the reservoirs of our ancient power know these boundaries, either. To deal with one without even alluding to the other is to distort our commonality as well as our difference. ${ }^{72}$

This absence of black female voices is certainly a loss; as Judylyn Ryan notes, black women have a long-standing and strong connection to the spiritual traditions of their communities: "the primary goal in an African cosmology is to attain and preserve equilibrium of interdependent relationship," and women play a crucial role in fostering this in their communities. ${ }^{73}$ Dub poets celebrate just this kind of female strength, which disrupts the iconic superwoman image projected by male black nationalists and emphasizes the agency of black women via their bonds with folk wisdom, spirituality, and community.

\footnotetext{
$7^{70}$ Cooper, Copper Woman and Other Poems, 37.

${ }^{71}$ Mary Daly, Gyn/Ecology: The Metaethics of Radical Feminism (Boston M A: Beacon, 1978).

${ }^{72}$ Audre Lorde, "An Open Letter to Mary Daly," in This Bridge Called My Back: Writings by Radical Women of Color, ed. Cherríe Moraga \& Gloria Anzaldúa (New York: Kitchen Table, 1981): 94.

${ }^{73}$ Judylyn S. Ryan, Spirituality as Ideology in Black Women's Film and Literature (Charlottesville: UP of Virginia, 2005): 270.
} 


\section{Pan-African Sensibility in Diasporic Female Dub Poetry}

Although women dub poets draw on the reggae rhythms, Rastafarianism, and pan-African sensibility of their male counterparts, they do so in new ways. The dominant male voices of these discourses are disrupted by the centralizing of female experiences and voices, as when Afua Cooper issues a pan-Africanist call to black nations across the globe to journey to freedom. She does so through historical female figures of the African diaspora, such as Nanny of the Maroons and Harriet Tubman. Similarly, in Lillian Allen's pan-Africanist poem "Freedom is Azania (South Africa Must Be Free)," which is dedicated to antiapartheid freedom fighters, she foregrounds the role of women: "as grandmothers carry their quiet breathing / fire hope / hooking the network of resistance / threads. ${ }^{.74}$ See, too, how Ahdri Zhina Mandiela re-appropriates the lyrics of Bob Marley to re-imagine black women's experiences in both "Black Ooman" and "Ooman Git Up." The title of the latter poem resonates with the title of Bob Marley's song "Get Up Stand Up"; however, here Mandiela re-contextualizes the rallying-call, using a black feminist framework that takes into account the intersections of gender, race, and class.

Although these women are writing against a male-centred pan-Africanism, they are also, of necessity, drawing on the themes and artistic influence of earlier male writers who have been influenced by pan-Africanism. It is fitting to note, for example, the links between Claude McKay and later female dub poets. While most Jamaican male dub poets and those of the wider diaspora were inclined to focus solely on race and class, McKay's earlier collection of poems did take the intersections of class and gender oppression into account to some extent, although this facet of his writing remains under-explored in the critical literature..$^{75}$ As mentioned earlier, McKay spoke to the specific struggles and suffering of local Jamaican women, addressing police brutality against workingclass black Jamaican women. In "The Apple Woman's Complaint" (as, too, in "A Midnight Woman to the Bobby") McKay highlights market women targeted by police for illegal vending, their only means of survival:

Ef meno wuk, me boun' fe tief;

S'pose dat will please de police chief!

\footnotetext{
${ }^{74}$ Allen, Women Do This Every Day, 105-106.

${ }^{75}$ James, A Fierce Hatred of Injustice, 100.
} 
De prison dem mus' be wan full,

Mek de's 'pon we like ravin bull. ${ }^{76}$

This perspective is unusual, as the later male dub poets have tended to tackle police brutality in a way that suggests black males are the central, sometimes even the only, victims of police violence. McKay's depiction of black women does not remain so nuanced or inclusive over the course of his career, however, with many of his later works presenting women in a much more reified, simplistic way.

The consistent thematic adoption of gender and class, as well as race, thus marks female dub poets off significantly from their male counterparts. It is important to note, however, that female awareness of these issues should not be seen merely as an outgrowth of women'sdiasporic experience of sexism, nor solely as a result of the influence of European and US feminisms, but instead as an outgrowth of their own cultural traditions. As Rhoda Reddock argues, feminism is not a Western import to the Caribbean. Indeed, she maps a long history of women's organizations in the English-speaking Caribbean and outlines the ways in which female organizing grew out of struggles for racial equality. ${ }^{77}$ She also considers prominent female figures such as the pan-Africanist Amy Ashwood Garvey, in documentation that helps challenge the view of panAfricanism as a solely male, essentialist framework.

Marson's address to the first International Women's Congress (1937) in Turkey on issues of gender and race is another clear indication of Jamaican women's early political consciousness. At thirty years of age, Marson was the only black woman present at the conference. ${ }^{78}$ She spoke poignantly about her tribulations in Britain and called on the white women present to help African women in their fight against racial and gender oppression. ${ }^{79}$

\footnotetext{
${ }^{76}$ Claude McKay, Constab Ballads, 114.

${ }^{77}$ Rhoda Reddock, "Feminism, Nationalism and the Early Women's Movement in the English Speaking Caribbean," in Caribbean Women Writers: Essays from the First International Conference, ed. Selwyn R. Cudjoe (Wellesley MA: Calaloux, 1990): 77. Reddock traces the history of women's groups in Jamaica such as the Lady Musgrave Women's Self-Help Movement of Jamaica (1865), the Women's Social Service Club of Jamaica (1918), and the Jamaica Women's Liberal Club (1937).

${ }^{78}$ Macauley, The Life of Una Marson, iii.

${ }^{79}$ Delia Jarrett Macauley notes that Marson was "the first black British feminist to speak out against racism and sexism in Britain" (The Life ofUna Marson, 74, 88-89).
} 
Louise Bennett's poem "Jamaican Oman" also articulates the reality of African-Jamaican women's long-standing tradition of feminist consciousness:

An long before oman lib bruck out

over foreign lan

Jamaican female wasa work

Her liberation plan. ${ }^{80}$

Reflecting on Bennett's poem, Carolyn Cooper observes:

'foreign lan Oman Lib' is rejected by Bennett's persona because it is perceived as failing to acknowledge the strategic difference between men and women. ${ }^{81}$

Among the female dub poets examined in this chapter, Allen's poem "I Am African" articulates her pan-Africanism in her strong cultural link to Africa. The tenor of this poem is very similar to that of McKay's "Outcast"; both identify Africa as the source and express spiritual oneness with the continent:

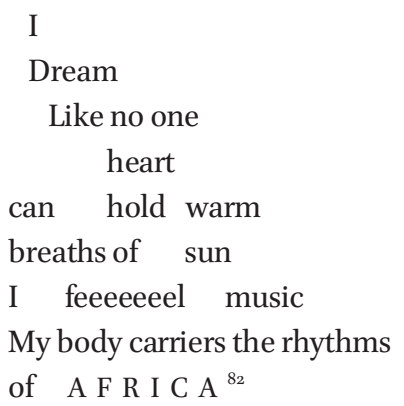

Allen's graphic marking of "feeeeeel" and "AFRICA" can be described as an African ideophonic linguistic expression which is an oral feature commonly found in "verse, prose narrative, song, music, and language play." ${ }^{n 8_{3}}$ This form appears elsewhere in Allen's poems: "WOO ooooooo OOO oooooo," "s4 "slave

\footnotetext{
${ }^{80}$ Louise Bennett, Selected Poems, ed. Mervyn Morris (Kingston, Jamaica: Sangster's, 1983): 21.

${ }^{81}$ Cooper, Noises in the Blood, 49.

${ }^{82}$ Allen, Women Do This Every Day, 118.

${ }^{83}$ Lupenga Mphande, "Ideophones and African Verse" (1992), in Tongue and Mother Tongue: African Literature and the Perpetual Quest, ed. Pamela J. Olùbùnmi Smith \& Daniel P. Kunene (Trenton NJ \& Samara, Eritrea: African World Press, 2002): 60.

${ }^{84}$ Allen, "Unnatural Causes," in Women Do This Every Day, 69.
} 
Shippppppp. ${ }^{\text {"85 }}$ Ideophonic representation is also found in Cooper's "True Revolution" (her emphasis on the word "degreeeeeeee"). ${ }^{86}$

In addition, Cooper covers the same ground in "Congo Wi Come From" although, unlike Allen, she chooses a specific country in Africa as a place of origin. In this poem she wittily recounts the contemporary fable of a US official's discovery of the mythical secret that waving a red 'Chango ${ }^{\circ 7}$ handkerchief can spellbind him into granting a visa:

So di wite bwoy fine out di secret

of di red handkerchief

dat wen yu flash chango inna im face

im haffi front up di visa

ah mossi one of wi tell im. ${ }^{88}$

Although the visa in question remains denied upon this discovery, Cooper is reminding her readers of the great powers of the African deities that have entered the spirit of black diasporic peoples:

Im no know seh wen

wi open wi mout an chant

an invoke

and recite

wi move mountains

wid wi words

so mek im gwan

mek im tink seh im win

mi im gwan

mek im tink she im know

all wi secret

mek im gwan sit back in im high chair

an stamp "denied" in di passport

an smile as im do so

mek im gwan

cause a Congo wi come from... ${ }^{89}$

\footnotetext{
${ }^{85}$ Allen, "Rub A Dub Style," in Women Do This Every Day, 83.

${ }^{86}$ Cooper, Memories Have Tongues, 71.

${ }^{87}$ Shango is a deity in the Nigerian Yorùbá tradition (and in the Shango cult of Trinidad).

${ }^{88}$ Cooper, Copper Woman and Other Poems, 82.
} 
In both "I Am African" and "Congo Wi Come From," Allen and Cooper draw on pan-Africanism through their use of recuperated African spiritual knowledges to articulate a poignant response to the circumstances of living in the diaspora. "Congo Wi Come From," in particular, sees these knowledges as superior to the institutional knowledge of the eurocentric Americas. While people of African descent may not immediately get justice, and while their cultural identity may be discredited, they are reassured by their conviction of the validity of their links to the continent, no matter how tenuous or far removed.

\section{Centralizing Diasporic Women's Lives}

The women dub poets considered in this chapter are clearly very aware of both theabsence of racialized women's experiences from Western feminist discourse and the ways in which different socio-cultural, economic. and geographical locations necessarily inform the way women's issues will be taken up. Female dub poets' centering of diasporic black women's lives presents an alternative narrative to the Western European feminist movement, one that articulates the struggle for black liberation and highlights the negotiation of belonging and citizenship in their host countries. As Lillian Allen avers, a feminist movement "must be of necessity anti-colonial, anti-imperialist and anti-sexist." ${ }^{\circ 0}$ It is through the prism of their local cultures (such as African-inflected music, language, and spirituality) that female dub poets explore their themes of womanhood. In doing so, they resist fixed notions of black women and uncover the intersections of gender, race, and class through anti-colonial and black feminist theories and practices.

Chapter 5 considers African-Jamaican aesthetics in the context of diasporic fiction. In the first section, I return to McKay's work, particularly the novel Home to Harlem, as a point of entry for mapping a diasporic aesthetic among African-Jamaican novelists working outside of Jamaica. McKay's novel reveals connections to, and divergence from, Jamaican literary traditions. Following this, I examine the work of the Jamaican-Canadian novelist Makeda

\footnotetext{
${ }^{89}$ Cooper, Copper Woman and Other Poems, 82.

${ }^{90}$ Lillian Allen, "A Writing of Resistance: Black Women's Writing in Canada," in In the Feminine: Women and Words, ed. Ann Dybikowski et al. (Edmonton, Alberta: Longspoon, 1985): 67.
} 
Silvera and the British Jamaican author Joan Riley, in order to highlight the continuities and transformations of African-Jamaican aesthetics in more contemporary fiction. I am again interested in how these writers, working from new, diasporic locations, transform and refashion their aesthetic roots. 


\section{5 \\ - Home Away from Home -}

The African-Jamaican Aesthetic in Diasporic Novels

N CHAPTER 2 I DISCUSSEd MCKAy's USE of an African-Jamaican aesthetic, primarily in the context of his earlier poems written in Jamaica. Here, I turn to his novel Home to Harlem (1937), written (after two earlier novels, Banjo, 1930, and Banana Bottom, 1933) while he was living in the USA after migrating there in 1912. One of the earliest, if not in fact the first, black Jamaican author to write a novel from 'abroad', McKay is of central significance for his emphasis on the value of indigenous knowledges and ancestral culture, an emphasis that runs through diasporic African-Jamaican fiction and is found much later in the work of the Jamaican-Canadian novelist Makeda Silvera and the British-Jamaican author Joan Riley. All of these writers, working from new diasporic locations, transform and refashion their aesthetic roots. This chapter builds upon anti-colonial scholarship by applying an indigenous model that deepens readings of African-Jamaican diasporic fiction.

As discussed previously, McKay's early collections of poems (Constab Ballad and Songs of Jamaica) represented a literature of decolonization because of the ways in which he experimented with creole and folk cultures to capture the experiences of Jamaican rural peasants and the urban working class. After migrating, McKay did not entirely abandon this project of valorizing Caribbean folk culture to create a new literary model. Banana Bottom, for instance, clearly championed the African-based aesthetic of Jamaican folk culture. However, his two other novels, Banjo and Home to Harlem, shifted the focus to the shared struggles of transnational black communities and the integration of an anticolonial and African-American aesthetic. There were likely a number of factors contributing to this shift, not least the internationalist perspective acquired 
from his travel abroad to countries such as the Soviet Union. His linguistic transition from a rudimentary transcription of Jamaican creole to the AfricanAmerican vernacular was likely an attempt to capture the voices of the AfricanAmerican working-class he was then living among. McKay's use of jazz also allowed him to be part of a larger conversation among black authors, who often appropriated African-based musical forms.

The publication of Home to Harlem provoked controversy in African-American literary, political, and intellectual circles. The chief criticism was that it exploited working-class black people by focusing on the 'vulgar' side of life in Harlem, thus creating stereotypical depictions of this community. ${ }^{1}$ Citing some of the criticism of the time, McKay's biographer Wayne Cooper reports:

After reading Home to Harlem W.E.B. Du Bois remarked that he felt unclean and in need of a bath. And Dewy Jones the black critic of the Chicago Defender lamented that white people think we are buffoons, thugs, and totters anyway why should we waste so much time trying to prove it? That's what Claude McKay has done. ${ }^{2}$

Additionally, Home to Harlem was accused of being modelled on, and a response to, the non-fiction work Nigger Heaven (1926) by the renowned white photographer Carl Van Vechten, a book which used primitivist fantasies to depict the lives of blacks in Harlem. McKay's use of animal imagery to describe his African-American characters and his exoticizing of black women's physical appearance are, indeed, problematic and one can certainly make the case that sections of the novel replicated colonial representations of black people. ${ }^{3}$ In these respects, his novel does share some similarities with Van Vechten's primitivist portrayal of African Americans. While one cannot overlook these troublesome issues, they need to be bracketed-off in order to permit concentration on how McKay's work nevertheless embodies indigenous meanings to assess African-American sociopolitical discourse and contested Euro-Western literary hegemony. It is also worth noting that McKay himself offered a response to those critics who believed his depiction of Harlem life was stereotypical and voyeuristic. In his autobiography A Long Way from Home (1937), he clearly allies

\footnotetext{
${ }^{1}$ Tillery, Claude McKay: A Black Poet's Struggle for Identity, 87-88.

${ }^{2}$ Cooper, Claude McKay: Rebel Sojourner in the Harlem Renaissance, 29.

${ }^{3}$ Carl Van Vechten, Nigger Heaven (New York: Alfred A. Knopf, 1926).
} 
himself with the black working-class communities from which he drew his characters:

I did not come to the knowing of Negro workers in an academic way, by talking to black crowds at meetings, nor in a Bohemian way, by talking about them in a café. I knew of the unskilled Negro worker of the city by working with him as a porter and longshoreman and as waiter on the railroad. I lived in quarters and we drank and caroused together in bars and rent parties. So when I came to write about the Negro, I did not have to compose them from an outside view. ${ }^{4}$

Indeed, all three of McKay's novels depict black working-class culture, and his insertion of popular music, folktales, and everyday black language challenged the traditional literary form of the novel.

One departure from Carl Van Vechten's treatment of Harlem is McKay's use of the African-American vernacular to give voice to the struggles of the poor, as he himself states:

If my brethren had taken the trouble to look a little into my obscure life they would have discovered that years before I had recaptured the spirit of the Jamaican peasants in verse, rendering their primitive joys, their loves and hates, their work and play, their dialect. And what I did in prose for Harlem was very similar to what I had done for Jamaica in verse. ${ }^{5}$

As noted in Chapter 2 above, McKay was groundbreaking with regard to his literary commitment to the black underclass, long before many of his Caribbean contemporaries. See, for instance, Derek Walcott's frank acknowledgement of the shortcomings of his early poetry in failing to privilege local language and culture:

What I wrote had nothing to do with what I saw. While I honoured and loved them in my mind, I could not bring myself to write down the names of villages, of fruits, the way the people spoke because it seemed too raw... And I found no lines that mentioned breadfruit, guava, plantain, cassava in literature. ${ }^{6}$

\footnotetext{
${ }^{4}$ Claude McKay, A Long Way from Home (1937; New York: Arno, 1969): 228.

${ }^{5}$ Claude McKay, "A Negro Writer to His Critics" (1932), in The Passion of Claude McKay: Selected Poetry and Prose, 1912-1948, ed. Wayne F. Cooper (New York: Schocken, 1973): 135.

${ }^{6}$ Derek Walcott, holograph MS (1973) of Another Life, book 1, p. 42, repr. in J. Edward Chamberlin, Come Back to Me My Language: Poetry and the West Indies (Urbana \& Chicago: U of Illinois P, 1993): 98 .
} 
In contrast to Walcott's initial neglect of local cultural particularity, his later works were successfully grounded in his West Indian identity (as were the writings of other twentieth-century authors in the region).

Given McKay's awareness of the narrow opportunities for the expression of black cultural in his home country of Jamaica, it is not surprising to find that he saw parallels with the African-American working-class struggle to gain selfhood and, like many of his peers in the Négritude movement, drew inspiration from his journeys in various parts of the world. While acknowledging and celebrating the bridge between Africa and the rest of the black world, he also deeply appreciated the diversity, and in some cases even division, that existed among different black communities. He resisted thereby a discourse that located and defined black cultural identity solely through Black Atlantic epistemology, and his novel sits well with a conceptual framework of

blackness being informed by a definite place of origin, Africa, and the ways in which ancestral relationships inform the continued evolving of cultural identity in the New World. ${ }^{7}$

Many critics of were so focused on the image of African Americans in Home to Harlem that they failed to appreciate the unique discourse of Caribbean diasporic experience embodied in the character of Ray, a Haitian immigrant to the USA. McKay also presents us with the African-American figure of Jake, and the interactions between the two men offer us a rich conversation across black diasporic cultural identities. Ray and Jake's friendship also suggests a pan-African sensibility and reality. Ray is the black Caribbean immigrant who does not quite belong and is often culturally misunderstood by his/her new AfricanAmerican neighbours and friends. The dialogue between Ray and Jake yields information about 'other' black experiences (beyond the US) and connects with a shared African past. Ray is a young intellectual who has fled the US military occupation of his homeland, and his narrative provides Jake with an education about the wider black world:

Jake sat like a big eager boy and learned many facts about Hayti before the train reached Pittsburgh. He learned that the universal spirit of the French Revolution had reached and lifted up the slaves far away in that remote island; that Black Hayti's independence was more dramatic and picturesque than the

\footnotetext{
${ }^{7}$ Reneau, “Dancing the 'Clearing’ in African Diaspora Narratives,” 20.
} 
United States independence and that it was a strange, almost unimaginable eruption of the beautiful ideas of the "Liberté, Egalité, Fraternité" of Mankind, that shook the foundations of that romantic era. ${ }^{8}$

As well as sharing stories of the Haitian Revolution, Ray also offers insight into the challenges of being an immigrant and expresses strong criticism of US imperialism:

"Let me tell you about it," the waiter said. "Maybe you don't know that during the World War Uncle Sam grabbed Hayti. My father was an official down there. He didn't want Uncle Sam in Hayti and he said so and said it loud. They told him to shut up and he wouldn't, so they shut him up in jail. My bother also made a noise and American Marines killed him in the street. (13738)

Ray's sharing of the Haitian Revolution gives his fellow characters, and readers, a revisionary history, one that values African civilization and celebrates triumph over Western colonization.

Ray also relates stories "of the old destroyed cultures of West Africa and of their vestiges,"

of black kings who struggled stoutly for the independence of their kingdoms: Prempreh of Ashanti, Behanzin of Dahomey, Ewari of Benin, Cetawayo of Zulu-Land, Menelik of Abyssinia... (135)

While this pan-African discourse might be seen as conveying idealized images of Africa, one can argue that Ray's narrative is driven by the need to present a counter-discourse to the overwhelmingly negative and distorted images of Africa conventionally offered. Walter Rodney righttly advised that colonized people require an anti-colonial prism to help disabuse the mind of the misrepresentations of black peoples and their histories. ${ }^{9}$ Ray's pan-Africanist vision operates within an anti-colonial discourse that challenges "Eurocentric culture as the tacit 'norm'everyone references and on which so many of us cast our gaze." ${ }^{\text {10 }}$ Ray's revisioning thus offers Jake a new understanding of Africa:

\footnotetext{
${ }^{8}$ Claude McKay, Home to Harlem (1928; Boston M A: Northeastern UP, 1987): 131. Unless otherwise indicated, further page references are in the main text.

${ }^{9}$ Walter Rodney, How Europe Underdeveloped Africa (Washington DC: Howard U P, 1982).

${ }^{10}$ Joe L. Kincheloe \& Shirley R. Steinberg, "Constructing a pedagogy of whiteness for angry white students," in Dismantling White Privilege: Pedagogy, Politics, and Whiteness, ed. Nelson M. Rodriguez \& Leila E. Villaverde (New York: Peter Lang, 2000): 11.
} 
Jake was very American in spirit and shared a little of that comfortable Yankee contempt for poor foreigners. And as an American Negro he looked askew at foreign niggers. Africa was jungle, and Africans bush niggers, cannibals. And West Indians were monkey-chasers. But now he felt like a boy who stands with the map of the world in colors before him, and feels the wonder of the world. (134)

McKay's choice of an Haitian character to offer this revisioning is telling, in and of itself. Ray troubles eurocentric depictions of Haiti and, by extension, of the Caribbean. Given Haiti's significant status as the first black-ruled Caribbean nation, a character from that country certainly works to further create literary decolonization. As the critic Carl Pedersen notes,

It is no accident that Ray comes from Haiti and not Jamaica. As the first independent black republic, Haiti represented a purer form of black culture, a culture that had been jeopardized by the intrusion of white civilization in the form of American troops."

McKay's American vernacular, like its Jamaican Patwa cousin, shares the feature of retaining African roots. As Jeutonne Brewer observes,

Twi, Igbo, Ewe, Efik - all Niger-Congo languages - Jamaican Creole, and Gullah all exhibit a similar lack of inflection to show time. Present, past, and sometimes future time are indicated by context rather than by verbal inflection. ${ }^{12}$

Observations by travellers and commentators in the eighteenth and nineteenth centuries also noted the "Creole-like features in African American speech"

and even today certain features of Ebonics, such as the absences of the linking verbs "is" and "are" widespread in Gullah and Caribbean English creole but rare or non-existent in British dialects. ${ }^{13}$

"Carl Pedersen, "Claude McKay: The True Inventor of Negritude," in Claude McKay: Centennial Studies, ed. A.L. McLeod (New Delhi: Sterling, 1992): 117.

${ }^{12}$ Jeutonne Brewer, "Possible Relationships between African Languages and Black English Dialect" (conference paper, 1970), quoted in Molefi Kete Asante, "African Elements in African American English," in Africanisms in American Culture, ed. Joseph E. Holloway (Bloomington Indiana: Indian U P, 2nd ed. 2005): 71.

${ }^{13}$ John Rickford, "Suite for Ebony and Phonics" (1997), in The Language, Ethnicity and Race Reader, ed. Roxy Harris \& Ben Rampton (London: Routledge, 2003): 166. 
In Book Two of the novel, McKay furthers his exploration of language when he exposes Jake to Jamaican Patwa through contact with anglophone Caribbean immigrants:

"You low an' dutty bobbin-bitch!"

"Bitch is a bobbin in you' sistah's coffin."

They were West Indian girls.

"I'll mek mah breddah beat you' bottom foh you."

"Gash it and stop you' jawing."

They were interrupted by another West Indian girl [...]

"She come boxing me up ovah a dutty 'Merican coon."

"Mek a quick move or I'll box you bumbol ovah de moon." (96-97)

Here, McKay showcases the distinctiveness and legitimacy of Jamaica Patwa. As Jake puts it, these characters have"a language all their own" (97). McKay also points to the stigmatization of the vernacular in its home setting: "They are wild womens, buddy, and it's a wild language they're using, too,' remarked a young West Indian behind Jake" (97). These passages can certainly be read as evidence of McKay's own commitment to Jamaican Patwa and, by extension, to other African-based vernaculars, as legitimate voices of the people, despite their marginal status in both the educational system of his native home and his adoptive country. After his brief encounter with the Caribbean immigrants, Jake begins to appropriate Patwa in his own speech patterns:

"Bumbole" was now a popular expletive for Jake, replacing other favorite expressions such as "Bull," 'and "blimey." Ever since the night at the Congo when he heard the fighting West Indian girl criy, "I'll slap you bumbole," he had always used the word. (130)

Jake's appropriation of Patwa expletives demonstrates Gilroy's notion of cultural exchang among African diasporic people.

In addition to language, McKay uses music, particularly jazz and dance, as an expression of black folk culture and a sign of his characters' emancipation from white cultural hegemony. In Home to Harlem, McKay uses pulsating and rhythmic language to illuminate the significance of dance in the lives of his characters:

They danced, Rose and the boy. Oh, they danced! An exercise of rhythmical exactness for two. There was no motion she made that he did not imitate. They reared and pranced together, smacking palm against palm, working knee 
between knee, grinning with real joy. They shimmied, breast to breast, bent themselves far back and shimmied again. Lifting high her short skirt and showing her green bloomers, Rose kicked. And in his tight nigger-brown suit, the boy kicked even with her. They were right there together, neither going beyond the other.... (93)

Although an argument can be made that McKay's use of a dance trope sometimes projects animalistic ('primitive') imagery of African Americans, he nevertheless effectively uses the cabaret primarily to feature, and again legitimize, a genuine dance and jazz aesthetic. Cabarets in New York were predominately frequented by African-American patrons and served as essential sites for them to escape the domination of white cultural norms and create their own unique space. The Congo cabaret certainly functions as such a site:

[...] the Congo remained in spite of formidable opposition and foreign exploitation. The Congo was a real throbbing little Africa in New York. It was an amusement place entirely for the unwashed of the Black Belt $[\ldots]$. The Congo was African in spirit and color. No white persons were admitted there. (29-30)

The name of the club itself is a knowing wink at a more liberatoryAfrican past. In this way, Africa is still present in the imagination of the characters although none of them may have made the journey back. As Reneau proposes in her framing of blackness, this sense of the past is underscored "by a philosophical understanding of origin and the ways in which a sense of origins informs a mode of being that is constantly in transition of engagement with various environments and ideologies." ${ }^{14}$

McKay also makes it clear that the Congo is a specifically black, workingclass space. For example, he describes the playing of "drag" blues, a musical genre banned in more upper-class clubs. In this way, the site of the Congo is an extension of the tradition of enslaved Africans finding private spaces, away from the watchful eyes of white masters, in which to continue their cultural traditions. McKay's images of the Congo can be seen to constitute an ethnographic look at black life, ${ }^{15}$ but there is more emotional intimacy in his use of this and other blues clubs and parties to signify primarily a local urban space of

\footnotetext{
${ }^{14}$ Reneau, "Dancing the 'Clearing' in African Diaspora Narratives,” 20.

${ }^{15}$ Robert E. Washington, The Ideologies of African American Literature: From the Harlem Renaissance to the Black Nationalist Revolt (Lanham MA: Rowman \& Littlefield, 2001): 81.
} 
cultural and sexual expression away from the constraints of a negatively watchful (neo)-colonial gaze. McKay's naming of his fictional club can also be linked to Congo Square, an historic site in New Orleans used by enslaved Africans who were brought from surrounding areas to play, sing, and dance under the surveillance of their masters. Although, in this case, the site was not ostensibly private or free, it still offered enslaved Africans a rare opportunity "to sing and play at length." ${ }^{m 6}$ And, in fact, their repertoire was said to include many African songs that had been banned for being part of Vodou rites. The slaves also danced (European) quadrilles and sang patois ditties and African chants above the "great drums." ${ }^{\text {"17 }}$ Hilary Beckles emphasizes the central role of music and dance in the Caribbean slave experience:

the linkage of these cultural encounters [... represented much more than the passionate pursuit of pleasure; they were encoded with noises of spiritual ideological liberation and invoked the voices of cosmological redemption. ${ }^{18}$

Given this history, it seems reasonable to propose that McKay is consciously drawing on a past African-American space (Congo Square) to stress the cabaret's function as an important venue of African cultural expression in a contemporary context.

McKay also turns to the Panama Canal as a compelling site of African diasporic culture. Ray's accounts of Caribbean migrant labour on the Canal (a local diaspora') illuminate African cultural link across the archipelago and promote a shared black consciousness. When Jake asks Ray about his blackness (“Ain'tchu - ain'tchu one of us, too?"), he replies:

"Of course I'm Negro" the waiter said, "but I was born in Hayti and the language down there is French."

"Hayti... Hayti," repeated Jake. Tha's where now? Tha's-"

"An island in the Caribbean - near the Panama Canal." (131)

Ray's locating of Haiti near the Panama Canal signifies it as a meeting point where diasporic Africans from scattered places share cultural exchanges and

${ }^{16}$ Baraka, Blues People, 72.

${ }^{17}$ Blues People, 72.

${ }^{18}$ Hilary M. Beckles, "'War Dances': Slave Leisure and Anti-Slavery in the British Colonised Caribbean," in Working Slavery, Pricing Freedom: Perspectives from the Caribbean, Africa, and the African Diaspora, ed. Verene A. Shepherd (New York: Palgrave, 2001): 223-24. 
discover common links. Ray's own conversations with Jake underscore Harlem's similarity to the Panama Canal in this regard. As Carolyn Cooper notes in an analysis of Home to Harlem, the Canal "denotes the explosive severing of the umbilical cord that once joined two continents":

it also, somewhat paradoxically, evokes bridges of sound. Another middle passage. In this place where so many dispossessed Africans risked their lives for the opportunity to make a living was created another meeting-place of African cultures. Panama, like Harlem, was a symbolic place that engendered conversation such as ours between the Jakes and the Rays of the African diaspora. ${ }^{19}$

John Lowney maintains that McKay's articulation of Caribbean immigrant narratives, through the story of a Haitian exile living in Harlem, establishes a unique literary ground for cross-cultural conversations between African-American and Caribbean critics of American imperialism. In doing so, McKay averts attention from the simmering conflicts between African Americans and AfroCaribbean immigrants that had politically divided Harlem, and in fact, had affected his own early career in New York. ${ }^{20}$ That McKay was committed to facilitating such cross-diasporic dialogue is noteworthy as an expression of his times and as a herald of today's unresolved debates among African diasporic peoples, which are often fraught with conflict and fall into postmodern discourses of fragmentation and over-emphasis on differences.

Although Ray rejects religion, proclaiming God as white and with "no more time for niggers than you've got for the chef' (176), McKay finds other ways to present religion as a significant factor in the lives of African Americans. The African-American pantry man, for example, expresses great shock at Ray's denunciation of religion. In another scene, McKay uses the setting of a pool room used by railroad and other African-American workers to highlight the place of religion in their lives:

And there were pretty chocolate dolls and pictures of Negroid types on sale.

Curious, pathetic pictures; black Madonna and child; a kinky-haired mulatto angel with African lips and Nordic nose, soaring on a white cloud up to

\footnotetext{
${ }^{19}$ Carolyn Cooper, "Race and the Cultural Politics of Self-Representation: A View from the West Indies," Research in African Literatures 27.4 (Winter 1987): 104.

${ }^{20}$ John Lowney, "Haiti and Black Transnationalism: Remapping the Migrant Geography of Home to Harlem," African American Review 34.3 (Autumn 2000): 426.
} 
heaven; Jesus blessing a black child and a white one; a black shepherd carrying a white lamb - all queerly reminiscent of the crude prints of the great Christian paintings that are so common in poor religious homes. (142)

Here we see that as McKay underscores the significance of religion in the lives of African Americans, he pays particular attention to africanized features in the biblical images he references. Such a reading challenges the usual presentation of Biblical figures as soley white and European.

Given McKay's clear literary commitment to African diasporic folk culture, it is surprising to find that neither Garvey nor Du Bois, the most vocal advocates of pan-Africanism at that time, was a supporter of his work. In fact, they opposed it and failed to recognize the ways in which McKay built upon a collective pan-Africanist consciousness, using his texts to imagine the possibilities of a global black community informed by indigenous African-influenced knowledges and a shared history of imperialism and slavery. McKay's approach was, in fact, in step with that of many other writers during the Harlem Renaissance. As Bernard Bell points out, "By and large, the New Negro turned to Africa and African-American folklore for the authenticity and authority of a usable ethnic past." ${ }^{\text {21 }}$ Melvin Dixon comes to the same conclusion in his comparative study of black literature, noting:

by acquiring a language and imbuing it with terms directly related to New World experience through music and folklore (indigenous creation), black writers created a bond amongst themselves through literature. ${ }^{22}$

Dixon's analysis suggests that critics of Home to Harlem may have paid too much attention to the African-American context, thereby overlooking McKay's use of the shared cultural literary form "used by black writers to reconnect to a common, ancestral resonance." ${ }^{\prime 23}$ It is particularly surprising that Garvey, a black Caribbean immigrant himself, is unable to see McKay's attempt to valorize folk culture or his taking-up of a pan-African diasporic discourse through the character of Ray and his friendship with Jay. Ray reminds us of these

${ }^{21}$ Bernard W. Bell, The Contemporary African American Novel: Its Folk Roots and Modern Literary Branches (Amherst: $\mathrm{U}$ of Massachusetts $\mathrm{P}, 2004): 106$.

${ }^{22}$ Melvin Dixon, "Rivers Remembering Their Source: Comparative Studies in Black Literary History - Langston Hughes, Jacques Roumain, and Négritude" (1979), in Melvin Dixon Critical Reader, ed. Justin A. Joyce \& Dwight A. McBride (Jackson: U P of Mississippi, 20o6): 49.

${ }^{23}$ Dixon, "Rivers Remembering Their Source," 49. 
diasporic and African connections when he responds to Jake's questioning of his blackness with "Of course I am a Negro" (131).

Again, I want to stress that my reading of Home to Harlem suggests that McKay's representation of a transnational black Harlem is more politically complex than many of his critics have granted. He creates a Harlem with a rich cross-cultural dynamic through the unfolding of two immigrant narratives in the diasporic black world. McKay's admittedly problematic representations of some of his black characters, especially his female ones, if viewed as stereotypically 'primitive', occludes the author's endeavour to continue the shaping of a literature of decolonization that he had initiated in Jamaica.

\section{The African-Jamaican Aesthetic and Contempoary Diasporic Fiction}

This section provides a textual analysis of The Unbelonging and The Heart Does Not Bend to uncover the authors' use of an African-Jamaican aesthetic to further support my thesis about the continuity of local cultures in the diaspora. This assumption stands in contrast to postmodern analysis of the diaspora which, while acknowledging cultural exchange, tends to over-emphasize cultural ruptures and neglecting the importance of Caribbean indigenous knowledges and African origins in the creative works and lives of African diasporic people(s).

McKay's trailblazing attempts to create a new diasporic literary discourse come to maturation in the novels of two African-Jamaican women decades later: Makeda Silvera's The Heart Does Not Bend (2003) and Joan Riley's The Unbelonging (1985). As with many of their contemporary African-Jamaican peers, for Silvera and Riley, perhaps even more than for McKay, an African-Jamaican aesthetic is a significant feature of their writings in their addressing of complex issues of belonging, racial and gender oppression, and sexuality. Although Silvera and Riley write from different diasporic locations, Toronto and London respectively, they each deploy indigenous knowledges from their island home in similar ways. ${ }^{24}$ Both authors integrate myth, cultural traditions, Jamaican proverbs, and nation language to develop the various themes in their writing. Unlike their earlier predecessors (such as McKay), many contemporary diasporic

\footnotetext{
${ }^{24}$ These similarities echo the approaches of the dub poets discussed earlier in this study.
} 
Caribbean writers are less concerned with experimenting with primitivism as a challenge to European literary hegemony and assertioon of a distinctive black aesthetic; instead, they are interested in affirming an independently imagined black identity of their own imagining.

Structurally, both Silvera and Riley centre their plots on female protagonists who migrate from their native land of Jamaica and are then faced with the struggle of negotiating identities in their new 'home' and wondering about the impossibility of returning to their old 'home'. For Riley's protagonist, Hyacinth, this negotiation and lingering thoughts of returning to Jamaica are painful because she must endure physical abuse and repeated rape by her father and the cultural isolation she faces at school. Silvera's character Molly attempts to repair a broken relationship with her grandmother, due to her homosexuality, and also hopes to mend her relationship with her mother, which has been ruptured by migration. For her own part, Molly's grandmother, Maria, struggles to regain her independence after moving to Canada. Both of these storylines are explored through an African-Jamaican aesthetic.

Although Silvera and Riley set their narration in Standard English, their ability to code-switch between languages allows them to deliver much of the characters' dialogue in Patwa. In this way, the characters are able to tell their stories in their own voices, thus offering an anti-colonial standpoint. The authors also highlight nation language through the interweaving of proverbs, folklore topoi, and storytelling. In The Heart Does Not Bend, for instance, Maria employs proverbs to chastise and advise her children and grandchildren, as well as to simply reflect upon life. As her son Mikey moves up into affluent Jamaica society, Maria cautions him to "remember seh de higher monkey climb de more im ass expose." ${ }^{25}$ And, as Molly naively reflects on the hardships of their life in Canada, Maria reminds her: "We cyan go bak girl, yuh can tink 'bout de past, but yu cyann go back fi live in it. Too much water gone a river." ${ }^{26}$ This use of proverbs also points to the privileging of female knowledge in black diasporic fiction. As recent African-American fiction demonstrates, there are countless ways in which mother wit can be used to challenge oppressive racial and sexual narratives. See for instance, the "Men without Skin" in Toni Morri-

\footnotetext{
${ }^{25}$ Makeda Silvera, The Heart Does Not Bend (Toronto: Random House, 2002): 68.

${ }^{26}$ The Heart Does Not Bend, 118.
} 
son's Beloved; Paule Marshall's Ibo water walkers in Praisesong for the Widow; or the presence of the ancestor in Michelle Cliffs No Telephone to Heaven. As Linda Watts concludes,

the incorporation of proverbs, both in the context of character dialogue and the direct address to the reader, enables authors to invoke the shared wisdom that otherwise might be lost or overlooked. ${ }^{27}$

Molly's great-grandmother, Mammy, is another wise matriarch, a griottte figure who preserves family history and African links through her sharing of personal and community narratives. Mammy narrates "slavery time," as Molly calls it, recalling her own birth date and her African born grandmother:

Is about $1890 \mathrm{mi}$ born yuh know, so mi pon dis earth long time. Mi see whole heap, mi born not far from here, Port Antonio. Dem time whole heap of ship use to come in from all over de world and dock dere. Is right dere dem dock mi grandmother, tek her from Madagascar, bring her pon slave ship to here. ${ }^{28}$

Mammy's passing-down of history to the next generation foregrounds the important role of women as storytellers and history keepers. Mammy's desire to stay connected to her ancestral past is displayed in the suggestions she makes: "Molly when yu go foreign, to go to Africa. Go see where mi grandmother born, and kiss de dirt fi mi." ${ }^{29}$ This wish to connect with an original homeland is often dismissed as an escapist and naive desire (and, given the torn integuments and cultural transformations caused by the Middle Passage, there have been more instances of disillusionment and disappointment than of a sense of true homecoming). Be that as it may, Mammy's desire for her great-granddaughter to visit Africa reflects Grace Nichols' observation that the sense of journeying 'home' always exists in Caribbean people's imagination, whether the return is real, metaphoric, or imaginary..$^{30}$ Afua Cooper describes this link to Africa as follows:

${ }^{27}$ Linda S. Watts, "Proverbs," in Watts, Encyclopedia of American Folklore (New York: Facts on File, 2006): 318.

${ }^{28}$ Silvera, The Heart Does Not Bend, 47.

${ }^{29}$ The Heart Does Not Bend, 84.

${ }^{30}$ Grace Nichols, comment on Frances Solomon's film adaptation of her poem-collection I is a long memoried woman (1990), in Simon A. James Alexander, Mother Imagery in the Novels of AfroCaribbean Women (Columbia: U of Missouri P, 2001): 99. 
the more I write the more I see what my subconscious is doing. This points to the fact we as Africans in the New World never lost the essence of our cultural heritage which, I believe is coded in our genes... ${ }^{31}$

Silvera's Mammy embodies this subconscious link between peoples of African descent, a persistent continuity in black diasporic cultural production.

Joan Riley adopts another approach to keeping Africa alive in her fiction; instead of relying on storytelling, she integrates a pan-African discourse. In The Unbelonging, the character of Hyacinth's best friend, Perlene, represents black consciousness. As with McKay's character Ray, Perlene dispels the distorted images of Africa as uncivilized and backward and recalls Walter Rodney in her pointing out that class prejudice and Western imperialism are still realities in Jamaica and the wider Caribbean. ${ }^{32}$ However, unlike Jake, who tries to understand Ray's narratives about US imperialism in Haiti, at first Hyacinth rejects Perlene's reflections in order to hold on to the idyllic vision she has of Jamaica as a free and independent black nation. It is not until she returns for a visit to Jamaica that Hyacinth is forced to accept Perlene's view that 'buckra' days are not yet over:

Laughter drifted under her door as footsteps passed by and she envied the guests. The tourists who came for sun, sea, excitement. They all had a place to go to; they were not forced to stay as she was. She could not dine with them tonight, stomach still full of the sight and smells, the fetid heat of that awful poverty. She felt a stab of irritation as more guests passed her door. How could they come here, live like lords and ladies? What justice said that to be black was to be inferior? It was so unfair, her mind cried out in frustration. She had run back to where black people ruled, only to find it was all a dream. They were all still slaves, still poor, still trodden down. ${ }^{33}$

For Riley, looking into the past includes acknowledging and understanding Jamaica's slave past and its effects. It is not until Hyacinth comes to terms with Jamaica's haunting plantation history that she can move forward.

${ }^{31}$ Afua Cooper, "Finding My Voice," in Caribbean Women Writers: Essays From the First International Conference, ed. Selwyn R. Cudjoe (Wellesley MA: Calaloux, 1990): $3^{0} 3$.

${ }^{32}$ Joan Riley, The Unbelonging (1985; London: Women's Press, 2001): 112-17. Unless otherwise indicated, further page references are in the main text.

33 Riley, The Unbelonging, 143. 
The relative absence of proverbial expressions and storytelling in The Unbelonging is, in part, the result of the lack of a maternal figure in the novel. Amanda Putman notes that "the mother's presence delivers crucial knowledge to subsequent family generations." ${ }^{34}$ Whereas Molly is connected to generational and cultural history through the orality (proverbs and storytelling) of her grandmother, great-grandmothers, and aunts, Hyacinth is deprived of this cultural transmission. ${ }^{35}$ In the absence of a physical mother, Putman stresses the significance of stand-in mothers or maternal figures:

within several Caribbean diasporic texts, alternative styles of mothering compensate for maternal losses, guiding motherless daughters to ancestral strength. ${ }^{36}$

Pointing to Edwidge Danticat's stories Krik? Krak! and Merle Hodge's Crick Crack Monkey as examples, she writes:

alternative mothers canoffer similar collective mothering practices, showing women within a community nurturing daughters whose mother is absent. Their purpose is to help the daughters acquire qualities which allow them to develop into strong Black women. ${ }^{37}$

In Hyacinth's case, the obvious candidate for an alternative mother is her stepmother, but she is not a figure of guidance or nurturing; thus, Hyacinth is left with a void that forces her to become "self-mothering." Unfortunately, despite her best efforts, Hyacinth's self-mothering does not meet all her needs; when she finally returns to Jamaica she is rejected by her family and fails to connect with her cultural roots.

\footnotetext{
${ }^{34}$ Amanda Putnam, "Mothering the Motherless: Portrayals of Alternative Mothering Practices within the Caribbean Diaspora," Canadian Woman Studies Journal/Cahiers de la femme canadienne 23.2 (Winter 2004): 118 .

${ }^{35}$ It should be noted that Riley does not always deprive her characters so. In her 1986 novel Romance, for instance, her characters are gifted with visits by grandparents who share AfroCaribbean stories and traditions, including creole tales of Anancy and the Maroons.

${ }^{36}$ Putnam, "Mothering the Motherless," 118.

37 "Mothering the Motherless," 118. Putman's term 'alternative mothers' recalls the AfricanAmerican feminist notion of 'other mothers' except that she takes into account the experience of maternal absence caused by migration, while the need for other mothers is presented primarily as a result of maternal loss due to the separation of mother and child during slavery and as a result of adverse familial conditions in the contemporary context.
} 
As indicated earlier, food imagery is an often significant means of expressing cultural aspiration and tradition in Jamaican diasporic literature. This can be seen at play in Silvera's The Heart Does Not Bend, where Molly and her grandmother hold onto their cultural past partly via traditional Sunday meals which bring the family together:

Every Sunday we had a full-course Jamaican dinner complete with rice and peas, fried chicken or curried goat, coleslaw and freshly made carrot juice... Those Sundays reminded me of our monthly parties on the dead-end street in Kingston, but they were not nearly as exciting... Still, the dinners brought us together, to laugh and remember what we chose. (92)

Silvera also shows us how Molly's frequent referencing of the tropical foods and traditional meals that remind her of her childhood is a means of sustaining her connection to back 'home'. The transplantation of Sunday dinner, foods, and other relational meals from Jamaica to Canada creates a space in the new diasporic location for a shared breaking of cultural bread to continue. It is through such practices that a Caribbean identity - and the cultural heritage, communal values, and shared ethos that such an identity implies - is passed on to generations born in the diaspora.

Heather Hathaway points out that such private domestic ritual can also be "profoundly political, especially to the degree that they mutually reinforce and serve as a foundation for other articulations of cultural identity. ${ }^{38}$ She goes on to note that Caribbean immigrants use both foodways and language to recreate homeland and provide comfort and protection in an often hostile diasporic environment. Sharon Beckford, in indicating the importance of food "to our understanding of the character and their histories, ${ }^{39}$ likewise remind us of the communal significance of food in transmitting cultural traditions, noting how crab season "represents one of the most enjoyable community social activities during rainy season" as well as its purpose as an economic source for

\footnotetext{
${ }^{38}$ Heather Hathaway, Caribbean Waves: Relocating Claude McKay and Paule Marshall (Bloomington: Indiana U P, 1999): 102-103.

${ }^{39}$ Sharon Beckford, "Taking a Piece of the Past with Us: Jamaica-Canadian Fruits of Migration in Makeda Silvera's Heart Does Not Bend," in Jamaica in the Canadian Experience: A Multiculturalizing Presence, ed. Carl E. James \& Andrea Davis (Halifax, Nova Scotia \& Winnipeg, Manitoba: Fernwood, 2006): 87 .
} 
communities. ${ }^{40}$ In line with this, Silvera employs the aesthetic of foodways as a vehicle not only of normal social interaction in narrative but also to indicate a process of political negotiation where local cultures can function in changed environments with a hedge against cultural amputation or assimilation.

In contrast to Silvera's use of food as a literary device to reflect Caribbean continuities, Riley's protagonist is not, in general, able to gain cultural nourishment through food; instead, meal preparation for her is an arena of oppression and punishment. Hyacinth's callous step-mother demands that she cook for the entire family as part of her daily chores, despite the fact that dinner time is not an occasion for positive familial community. There is one scene, beyond the domestic circle, where Hyacinth shares a meal of salt mackerel and green bananas with a friend in her dormitory and is transported back to pleasant memories of Saturday evenings spent in Kingston with "onions frying and a sun-bleached, grey wood shack" (105). Foodways as an expression of cultural ties are otherwise absent from the novel. It is thus not surprising that, as foodways are associated with storytelling, Hyacinth is unable to gain any benefit from the flow of either of these local traditions. This is in contrast to Molly, who is able to gain and sustain a sense of local culture via community meals and baking rituals with Mama.

However, both Silvera and Riley allude to other cultural rites that are reflective of the West African cultural traditions that form a basis for AfricanJamaican culture. In The Heart Does Not Bend, for instance, Silvera makes reference to the African funeral ritual of washing every piece of the deceased's clothing and then putting these "away for ten days before wearing." ${ }^{41}$ And Riley calls up the sounds of drumming and dancing in Hyacinth's dream to refer to the John Canoe ceremonial celebrations traditionally held during the Christmas season in the Caribbean:

The music was getting louder, the pounding drums more insistent, but still there was no sign of a band, no dancers appearing along the wide well-kept street... The music was so loud, it was everywhere. How could the band and dancers not be there. [...] She wanted to get away from it, from the sudden tininess of the drums, the artificial whine of the electric guitar. (97-98)

\footnotetext{
${ }^{40}$ Beckford, "Taking a Piece of the Past with Us," 87.

${ }^{41}$ Silvera, The Heart Does Not Bend, 8.
} 
(In this scene Hyacinth longs to escape the dream - the drumming, transplanted to the desolate streets of England, evoke violence rather than the communal festivities of the John Canoe parades of her youth.) Silvera references John Canoe festivities as well through flashbacks that Molly experiences:

The waiting area was like Christmas morning in downtown Kingston. I kept expecting to see Junkanoos on silts, their faces smeared in mud, horns on their heads, wire tails, dancing to drumbeats. ${ }^{42}$

Memory in Silvera and Riley consoles characters for the alienation and disappointments of migration. As Winston James observes, "Exiles inevitably carry memories of home with them, especially in the early years of separation." ${ }^{43}$ James' observation is certainly true in the case of Silvera's and Riley's protagonists. Childhood memories, especially those illuminated by the landscape of Jamaica, serve to reveal the inner experiences of the characters. Molly holds on fiercely to her recollections of a childhood spent with her grandmother and also reminisces about other relatives and playmates in compensation for the impossibility of forging a bond with her biological mother in Canada. Similarly, Hyacinth clings to idyllic childhood memories of time spent with her aunt and playmates as balm for the wounds of her present reality, which includes the physical abuse and sexual violence of her father, verbal abuse from her stepmother, and cultural alienation at school. Molly and Hyacinth also lament the loss of freedom that the landscape of the islands offered them, the same landscape Cooper remembers so fondly in her poems. Hyacinth's recollections of her childhood, for example, are often presented in the form of dreams where the physical environment is central:

They had enjoyed their recess breaks, the three of them, walking in the school grounds, sitting under the big spreading Bombay mango tree. There was always plenty to talk about, plenty to plan. (15)

The memories found in these novels call attention to the sense of 'in-betweenness' and unbelonging experienced by many black diasporic people. Unfortunately for Hyacinth, these memories become dangerous, locking her away in a parallel reality that gives her a false sense of security in London. Through her dreams, she holds on to the time spent with her Aunt Joyce in

\footnotetext{
${ }^{42}$ Silvera, The Heart Does Not Bend, 17.

${ }^{43}$ James, "Becoming the People's Poet," 18.
} 
Jamaica and this psychic escape prevents her from adequately negotiating her space and identity in England. She despises the way she looks, attributing her unhappiness and misfortunes to being black (62). Only once in the novel is she able to confront the not-so-pleasant memories of Jamaica and even then she holds steadfastly onto the joyful ones. As her friend Colin cautions her, "I too romanticize aspects of my country when I feel homesick. There is no harm in it, so long as I know the reality" (121).

It is important to keep in mind here that this kind of romanticizing, which specifically involves a realistic remembering of 'home' (which consoles the immigrant subject, as we see in some of Afua Cooper's childhood poems and through the foodways trope that Silvera uses; and the recollection of early childhood memories of meal preparation with Mammy and community meals to provide comfort for Molly), differs from postmodern assumptions of nostalgia or escapist ideal images of the home country. Hyacinth's friend Perlene best exemplifies how remembering does not automatically lead to naive nostalgia. While Perlene shares pleasant memories of her youth in Jamaica with Hyacinth to ease her homesickness, she also tells her of the grime, poverty, political corruption, and class and colour prejudice that are present as well. This is close to how Linton Kwesi Johnson sees Jamaica after he leaves and returns to the island.

Despite the potential pitfalls of romanticizing, memories do help Silvera's and Riley's characters survive the isolation and pain caused by migration and racism in their Canadian and British contexts. The fantasized memory Hyacinth cherishes of Jamaica enables her to endure not only this alienation and racial oppression but also to negotiate and survive family violence. Riley makes it clear to readers that Hyacinth's idealized fantasies of Jamaica are a reaction to having to cope with her cruel and alienating present life:

How much she longed for the sun-bleached cheerful of the grey wood shack that had been her home for the first eleven years of life. How different it had been from the peeling, black painted house full of fear and hate. [...] It had been so nice with Aunt Joyce who always understood, had never treated her badly. She had been popular with lots of friends. No one had teased her, taunted her. Now her only happiness was sleep, for that was when she could go home again and take up her interrupted life. (28) 
Riley's approach here calls to mind McKay's poem "I Shall Return"; both offer a "refuge in memory" as a means to heal and nourish characters through the remembering of a cultural past. ${ }^{44}$ This continuity of culture through memory is poignantly expressed by Edwidge Danticat's character Sophie, who states that she comes "from a place from which you carry the past like your hair on your head. ${ }^{45}$

This connection to homeland extends beyond memories. For many of the characters in The Unbelonging and The Heart Does Not Bend, the Caribbean is not a mythic site but a lived one. This stands in contrast to postmodern readings of 'home', which typically envisage it as a symbolic space for diasporic peoples. Such a reading does not encompass the realities of transnational AfroCaribbean communities. The black Canadian diasporic 'motherland' (Trinidad) is for Charmaine Crawford much more than an allegorical space. It is a concrete reality she engages with daily through ongoing contact with relatives and the regular remittance of needed funds and goods. ${ }^{46}$ The same is true in Silvera's story. While in Jamaica, Molly and her grandmother receive parcels and remittances from her children in Canada. And Maria, Molly's grandmother, engages in the same practice when she migrates to Canada, this time becoming the sender. Foods journeying directly from Jamaica also become an extension of this concrete reality, so that, when Mama's eldest son Freddie migrates to Canada she sends "escoveitch fish" and "fruit cake" and when she and Molly arrive in Canada they bring "fever grass, dried cerasee, leaf of life and other herbs for medicinal purposes. ${ }^{n 7}$ While Hyacinth's contact with Jamaica is initially only through her dreams, when she meets Perlene the latter updates her on current events in the country, and when she does return for a visit she is reprimanded by relatives for not having maintained contact.

As in McKay's work, Silvera and Riley also integrate religion and spirituality into their novels. Unlike the African-centred religiosity some of the dub poets display, however, Silvera and Riley refer primarily to a traditional black

\footnotetext{
${ }^{44}$ James, A Fierce Hatred of Injustice, 18.

${ }^{45}$ Edwidge Danticat, Breath, Eyes, Memory (New York: Vintage, 1994): 234.

${ }^{46}$ Charmaine Crawford, "Sending Love in a Barrel: The Making of Transnational Caribbean Families in Canada," Canadian Woman Studies Journal/Cahiers de la femme canadienne 22.3-4 (Spring-Summer 2003): 104-109.

${ }^{47}$ Silvera, The Heart Does Not Bend, 21, 88.
} 
Christian church, which is is central in the day-to-day lives of their characters. In The Heart Does Not Bend, for example, we see this through Mama's constant quoting of Bible verses, her participation in prayer meetings, and the daily prayers she issues for relatives and friends. And although Hyacinth turns primarily to her dreams for comfort whenever she finds herself in a difficult situation, she turns to religion for support. This is noted in a scene in which she is escaping the terror of her abusive father:

The tears flowed on, aching in her throat, the only warmth on her whole body. 'God, don't let them kill me! She whispered. 'I didn't do anything. It wasn't my fault. I'm sorry I don't go to church but he wouldn't let me. Please, please don't let them kill me. (64)

Ironically, while the church offers solace for some of the characters, it is the same institution that condemns Molly's lesbian lifestyle and deepens her sense of alienation. Silvera also uses this space of ostensible solace to express the intolerance shown by the church toward homosexuals through the women characters who are relied on by others "for redefinition of self." ${ }^{38}$

Although her focus is on the traditional black church, Silvera does include alternative black religious practices, such as Pocomania and Revivalism, through the African-centred great-grandmother Mammy:

For as long as I knew her, Mammy had been a member of a revivalist church whose members were known as Pocomanians. Services were held in a boarded up building with a dirt floor, and were very different from those at the Anglican Church I went to in Kingston. Mammy's was a livelier church, and spirits came upon the congregation, sometimes making them dance and jump and talk in tongues. Once I was seven, the spirit had come upon Mammy. Her seventy year old body had moved in frenzy, and she'd shouted out her praise in tongues.....99

Mammy's embrace of her African-centred spirituality throughout the first part of the novel is consistent with her link to ancestral memory. The spirit possession mentioned in the above passage is very similar to that described in Marson's poem "Gettin' de Spirit"; both present alternative modes of worship

\footnotetext{
${ }^{48}$ Davis, "Translating Narratives of Masculinity Across Borders: A Jamaican Case Study," 32.

${ }^{49}$ Silvera, The Heart Does Not Bend, 47.
} 
within a Christian frame. As Curdella Forbes notes, Erna Brodber's use of Caribbean religion

inserts an alternative vocabulary, rooted in Caribbean religious tradition, into Caribbean literary discourse. Her culturally grounded yet globally inclusive spiritualism allows her to deal with black experience without creating a new hegemony of difference to replace the old hegemony of universalism. ${ }^{50}$

This chimes with the way Silvera and Riley employ a religious and spiritual aesthetic to map out distinctively Caribbean ways of knowing and legitimize black diasporic spaces.

Thematically, The Heart Does Not Bend and The Unbelonging are structured around common diasporic experiences such as the disappointments of migration, the challenges of negotiating identities and reconstructing home, and, especially, the impossibility of return. For Hyacinth, the complexities of return are particularly pronounced. When she finally manages to return to Jamaica, instead of receiving a warm homecoming, she is chased by angry relatives away from the family dwelling and accused of having abandoned them: "Go back whey u come from. We noh like faringners in J.A." (142), one of them exclaims, impugning her for migrating away from the island. This absence of hospitality plays into the postmodern argument about the impossibility of ever returning to one's birth country, given the inevitability of change over time and the challenges of maintaining relationships marked by migration. Silvera, by contrast, suggests that a return to one's origins is possible in some respects. Molly is warmly welcomed by relatives and friends despite the lengthy time spent away from the island (both Molly and Hyacinth leave Jamaica at about the same age, in late childhood). And although Molly, like Hyacinth, is disturbed by the social changes she encounters in Jamaica (for example, the negative effects of neocolonialism including dire poverty and corruption), she is nevertheless able to reconnect to the culture of the country, including the food, the language, and the reggae music that she often hears blaring in the background. Molly's reconnections to the land of her birth are similar to those of the narrator in L'Exil selon Julia (1996), an autobiographical novel by the Guadeloupean writer Gisèle Pineau. Gisèle, the narrator, although born in Paris of Guadeloupean parents

$5^{50}$ Curdella Forbes, "Redeeming the Word: Religious Experience as Liberation in Erna Brodber's Fiction," Postcolonial Text 3.1 (2007): 17. 
and mainly raised far from the Caribbean, in her late teens she is able to go back to and reinsert herself into Guadeloupe's landscape, falling back into the native language of Krèyol and revelling in the foods and culture around her. While Gisèle's French citizenship does not provoke a significant rupture in her sense of belonging to and reconnection with her parent's place of birth, she is at times viewed as too cosmopolitan by the islanders. Molly faces the same challenge when she is labelled a 'faringner' by some of the Jamaican residents.

As in the work of the female dub poets discussed earlier, Riley and Silvera offer a critical representation of sexuality and gender oppression. Silvera's protagonist struggles with her sexual orientation because her Christian fundamentalist grandmother is unable to accept her lesbian commitment. While the host country (Canada) offers a more open discourse on sexuality, in Afro-Caribbean diasporic communities homosexuality is generally a taboo subject; that what one does privately beyond heterosexual norms should not be given a public hearing. Silvera's narrative of female romantic love subverts this taboo and presents a "powerful counter-discourse to homophobic and ethnocentric notions of masculinity that consider lesbian love a threat.".51 Silvera confronts the sexual orientation of Molly and her gay Uncle Mikey head-on, creatively harnessing Jamaican proverbs, nation language, and religion to open up discussion, albeit in the terms of a traditionally homophobiy community. For example, in one scene Mama creolizes a Bible verse to express disapproval of Molly's lesbian life-style:

Think 'bout her, if yu won't tink 'bout me. Mek friend wid yu Bible, for a de only weapon dat can drive wey Satan away. Yu know seh dat di wicked will not inherit the kingdom of God? Neither di sexually immorals, nor idolaters, nor male prostitutes, nor homosexual offenders. So I Corinthians. Sodomite cyan flourish inna God sight. It nuh right, it dangerous..$^{2}$

While earlier writers make some veiled references to homosexuality, ${ }^{53}$ changing social mores allow contemporary diasporic writers such as Silvera to address the topic explicitly.

\footnotetext{
${ }^{51}$ Amy Kebe, "Geographies of Displacement," 293.

$5^{2}$ Silvera, The Heart Does Not Bend, 186.

${ }^{53}$ For example, McKay, Home to Harlem, 80, 129.
} 
Riley's narrative, by contrast, operates in a heterosexual context to broach such hithertoo taboo subjects in many black diasporic communities as incest and rape, in line with other writers of African descent (see Alice Walker's The Color Purple and Toni Morrison's The Bluest Eye).

\section{Indigenous Knowledges as a Liberating Force}

These textual analyses of Home to Harlem, The Unbelonging, and The Heart Does Not Bend demonstrate the ways in which an African-influenced aesthetic can express cultural continuities and heterogeneous identities in diasporic spaces. As the characters negotiate their identity, their connections to local black cultures remain central to them. The authors propose an inclusive vision of subaltern individuals and spaces where indigenous knowledges are a liberating force. Like their dub-poet peers, the novelists in this chapter explore vernacular language, proverbs, cultural practices, folk culture and spirituality, and black church life as means of creating a self-nurturing or critical space that resists the linguistic and cultural 'norms' imposed by the white mainstream. Foodways, memories. and 'alternative mothering', in particular, reflect the importance of cultural transmission and continuity of indigenous cultures in the lives of African diasporic people, especially given the danger of fragmented selves as a result of a history of slavery, oppression, and forced migration. McKay, Riley, and Silvera also exhibit a pan-African sensibility that seeks to reclaim a stolen African past and to correct traditional colonial interpretations of Africa. In providing a revisionist history, these authors assert historical agency to avoid an "amputation of the past." ${ }^{\text {4 }}$

The Heart Does Not Bend and The Unbelonging also take up the metaphorical and literal concept of 'return'. While the return to Jamaica is traumatic for Hyacinth and reads along the postmodernist frame of the impossibility of return, Molly is able to make the transition of return and feels a sense of reintegration into Jamaican society. Grant Farred notes that Stuart Hall characterizes the concept of 'return' to the homeland as an idealized and almost impossible dream. By contrast, Farred points out that the new black diaspora is marked by ongoing transnationality with continuous cycles of migration,

\footnotetext{
${ }^{54}$ Dei, "Spiritual Knowing and Transformative Learning," 129.
} 
journeys, and returns. ${ }^{55}$ This pattern differs from the experiences of black people in the initial diaspora born of slavery and colonialism. As the diaspora scholar Aubrey Bonnett, echoing Farred, notes,

within the late twentieth century, and now in the new millennium, the transnational forces of the new migrations have brought into play a different and new diaspora which contributes more financially to the homeland, has redrawn the political interconnections between the "homelands" and the host society, and which now play a pivotal intervening role in the reconstruction of home..$^{6}$

Hall's claim that "you can go home again, you just can't stay" is not wholly valid in a globalized world in which home may be much more than an unreachable idealized space. Afro-Caribbean people can, and do, go home to stay. Hall's emphasis on the rupture between home and host countries needs to be re-conceptualized, given recent diasporic migratory realities. Current work on transnationalism does not stress disconnection but, rather, underscores continuities between spaces of origin and spaces of migration. Recent scholars ${ }^{57}$ identify the internet, dual citizenship, remittance, phone cards, affordable air fares, and international courier services as some of the factors that make it possible for transnational migrants to maintain much closer ties to their homelands than previous generations of immigrants. This transnationalism, which supports the continuity and flow of indigenous knowledges and an African-Jamaican aesthetic in diasporic spaces, is a reality that requires further critical analysis in relation to creative works such as fiction.

\footnotetext{
${ }^{55}$ Grant Farred, “You Can Go Home Again, You Just Can't Stay: Stuart Hall and the Caribbean Diaspora," Research in African Literatures 27.4 (Winter 1996): 28-48.

${ }^{5}$ Aubrey W. Bonnett, "The West Indian Diaspora to the US A: Remittances and Development of the Homeland," in Forum on Public Policy (2006), http://www.forumonpublicpolicy.com /archivesumo7/bonnett.pdf(accessed 15June 2014).

${ }^{57}$ Karim H. Karim, The Media of Diaspora Transnationalism (London \& New York: Routledge, 2003); Luis Guarnizo, Arturo I. Sánchez \& Elizabeth M. Roach, "Mistrust, Fragmented Solidarity, and Transnational Migration: Colombians in New York City and Los Angeles," Ethnic and Racial Studies 22.2 (1999): 367-96.
} 


\section{- Conclusion -}

A

DIASPORIC FRAMEWORK provides a useful entry point for the examination of Jamaican diasporic creative writing, taking into account as it does the specificities of local context. However, the framework suffers from a lack of flexibility in considering the role of African Caribbean indigenous knowledges and continuities in black diasporic literature. One can appreciate how diaspora studies, in shifting away from statically conceived notions of culture and cultural identity, has focused on the complex multiplicities of migration and local context, but an over-emphasis on the fragmentary aspects of black diasporic cultures has resulted in a tendency to neglect the depth and width of African histories in the diaspora. The unfortunate result of this tendency is a privileging of eurocentric discourse that discounts African origins. The foregoing chapters have attempted to illustrate how an African-centred discourse grounded in folk cultures is useful for understanding the richness of black diasporic experience in general, and literary works in particular. Religion, ancestry, language, and history are all essential features of African folk culture and thus provide a useful prism through which to view black diasporic writing. Many creative writers of African descent have also woven notions of race, gender, sexuality, and pan-Africanism into their work as they explore identity and place in new diasporic spaces. Thus, Dei's expansion of indigenous knowledges (working within an anti-colonial frame), VèVè Clark's diaspora literacy, and Christel Temple's literary pan-Africanism have all been useful concepts in providing a close look at Jamaican literary history through an indigenous perspective and drawing on alternative ways of knowing.

This kind of literary analysis has typically been marginalized in the academy. Similarly, black diasporic writers (minorities within racialized societies) have faced challenges as they seek to legitimize their alternative aesthetic and insist on their ties to Africa; nevertheless, in carving out an integral cultural niche 
many of them have achieved critical and popular acclaim in the metropolitan economy. ${ }^{1}$ Regardless of their geographical location (Canada, the UK, or the USA), the diasporic African-Jamaican writers examined here are the children of a history of oppression and in their works seek to expose and politicize African diasporic experiences, harnessing language, rhythm, historical allusions, spirituality, and traditional cultural practices to create a literature that can sit alongside the Euro-Western canons of their adoptive homes. The living continuities of Africa in black diasporic communities are captured by Keith Mitchell in his comments on Afua Cooper:

Blackness is not primarily socially constructed. There is something essential, part of the African diaspora collective consciousness, which speaks to black ontology and epistemology. Her historical texts, as well as her poetry, show that the middle passage, slavery, and its traumatic aftermath are primary ties that bind Black people in the past and present African diaspora. ${ }^{2}$

Far from being an essentializing of blackness, Mitchell's rejection of the idea of a socially contructed blackness does not fall into the trap of homogenizing black identities. Rather, he acknowledges a collective history among people of African descent despite their various diasporic locations. Cultural connectivity across space and time runs through the work of the writers surveyed here.

In addition to writing about the condition of black diasporic peoples, these writers have been politically active in community organizations and social movements in Jamaica and its diaspora - activism fuelled by a passion for social justice.

\footnotetext{
${ }^{1}$ For example, in 2008 Benjamin Zephaniah was included in the Times list of Britain's top fifty postwar writers (interestingly, Derek Walcott was thirty-first on the same list). He was also selected for the Order of British Empire (OBE) in 2003, an honour he turned down because the title reminded him of "how [his] foremothers were raped and [his] forefathers brutalized." For an example in Canada, see Afua Cooper's work, which has been widely recognized through various awards: her co-edited book We're Rooted Here They Can't Pull Us Up: Essays in African Canadian History won the Joseph Brant award for history; her poetry book Memories Have Tongue was a finalist in the 1992 Casa de las Américas literary award; her book The Hanging of Angélique was nominated for a Governor-General's Literature Award, and she was named among Essence magazine's "Women Who Are Shaping the World" in 2005.

${ }^{2}$ Keith B. Mitchell, "A Still Burning Fire: Afua Cooper's Triptych of Resistance," in Beyond the Canebrakes: Caribbean Women Writers in Canada, ed. Emily Allen Williams (Trenton NJ: Africa World Press, 2008): 40.
} 


\section{Nation Language and African-Jamaican Writing}

In their work, the writers surveyed in this study integrate Jamaican Patwa in their literary expression as a national language which serves as an important marker of cultural continuity in the diaspora. That writers of African-Jamaican descent, struggling to carve out a place in eurocentric diasporic spaces, should be so committed to validating Patwa is impressive, particularly as they are coming from a colonial history of consistent devaluation of nation languages, on the one hand, and over-valorizing of Euro-Western literary models and styles, on the other. Indeed, creoles have a long history of marginalization as dialects that branded their users as poor, uneducated, and racially inferior. In the face of this prejudice, Jamaican Patwa gained acceptance thanks to the early Jamaican writers Claude McKay and, to a lesser extent, Una Marson, for whom Patwa was a legitimate vehicle for expressing complex and profound ideas. It goes without saying that Louise Bennett always enjoyed popular appeal among her folk audiences, an appeal that raised her status to that of a national icon and enabled her subtle creole poetry to enter the literary mainstream. African-Jamaican writers also integrated other African-based oral aesthetic phenomena such as proverbs and orality (as Chinua Achebe and Amos Tutuola have done in West Africa). Though these writers maintained cultural continuity through their use of nation language, we also see the linguistic negotiations they had to make in reaching their audiences. McKay abandoned the full use of Jamaican Patwa in his later works, choosing English as the primary medium for connecting to a US audience, as he sought to articulate the struggles of transnational blacks in, but also beyond, his own home nation. McKay did continue to use Patwa (as in Banana Bottom), albeit to a lesser extent, alongside American black vernaculars (in dialogue) and inflected with the rhythms of jazz. In the final analysis, the use of Patwa and other black creoles helped establish a literature of decolonization, which would serve as a model for future Jamaican diasporic authors.

While diasporic dub poets follow their predecessor Louise Bennett's early lead in centralizing Patwa in their texts, the more recent dub poets (like hiphop performers with their use of Ebonics) tend to segue seamlessly from Standard English to Patwa and back, and, irrespective of their diasporic location, make liberal use of proverbs, storytelling, and other forms of oral culture to convey the desires, concerns, and challenges facing their new communities. 
Benjamin Zephaniah, for instance, insists that both English and Patwa are part of his linguistic identity and he is interested in how poets can use the English language in new and creative ways to subvert linguistic hegemony. Interestingly, this negotiating between language varieties is also found among dub poets living in Jamaica. One exception to this kind of shifting is Linton Kwesi Johnson, who, with the exception of some very early poems, has maintained a stronger creole link in his poetry. For him, Patwa is the true voice of his people. We see this approach in Rastafari speech as well, which subverts the English of 'Babylon', the colonizer; thus, words such as "understand" are changed to "overstand" and "dedicate" to "livicate," to express a highly differentiated cultural ideology of passive resistance andd spirituality.

Modern fiction writers such as Makeda Silvera and Joan Riley tend to follow their dub poet peers and navigate between English and nation language. While Standard English is their chief narrative mode, they also weave Patwa and African-Jamaican proverbs into their texts (primarily through dialogue) to signify their characters' cultural identity. Reflecting on the importance of language in black fiction, the Canadian literary critic Donna Nurse notes that "English militates against the kind of stories many Black people would like to tell." Silvera's practice as a writer bears testimony to this: writing about her struggles to pen a short story in her collection Remember $G$, about the experience of being harassed and strip-searched by a racist Canadian immigration officer, she notes that the narrative failed to emerge effectively when she tried to shape it in Standard English:

The characters would not have it. They were Jamaican. The woman was angry, and her anger could not be expressed in the Standard English - it did not have the words, and the story would make no sense unless I wrote in patwah. After Remembering $G$, writing in Jamaican patwah became easier. ${ }^{4}$

Here Silvera assumes the responsibility of writing her story in a form of language that arises from narrative necessity rather than being a reflex of external norms, just as Linton Kwesi Johnson is compelled to speak in the language of

\footnotetext{
${ }^{3}$ Donna Nurse, What's a Black Critic to Do, II: Interviews, Profiles and Reviews of Black Writers (Toronto: Insomniac, 2003): 197.

${ }^{4}$ Makeda Silvera, The Other Woman: Women of Colour in Contemporary Canadian Literature (Toronto, Sister Vision, 1995): 415.
} 
his audience. In doing so, these writers give "the language and its speakers presence. ${ }^{5}$

The use of language by African-Jamaican writers resembles that of other black diasporic authors in that it is marked by its membership in an African oral continuum that takes many forms such as warnings, prophecies, testimony, 'cuss cuss', proverbial expressions, songs, and storytelling, forms that are employed to great effect. Louise Bennett's early 'cuss cuss' poems set the stage for Lillian Allen's "dub renegade" essay with its central trope of "name calling" to confront Canadian bias against oral literature as a legitimate form of literary expression. She also uses this trope, along with echoes of the work-song tradition, in her poem "I Fight Back" to criticize the exploitation of black women's labour.

\section{Feeling the Spirit in African-Jamaican Literature}

The integration of religion in literary endeavour is a persistent feature of black diasporic writers and another marker of African cultural continuity despite attempts to suppress black spirituality. Ngũgĩ wa Thiong'o notes that the colonizer banned indigenous African religions, which tended to be connected to the natural world. The Caribbean has its own record of discarding and pathologizing African-based religion and spirituality. Yet black religion survives as a strong thread in literature. Both McKay and Marson document black forms of worship in their fiction. In a contemporary context, many of Afua Cooper's and 'Binta' Breeze's poems, and to a lesser extent Silvera's novels, offer an oppositional discourse by reclaiming African-centred religion, spirituality, and associated folk wisdom as meaningful aspects of African-Jamaican identity and as remembrance of their ancestral past. Linton Kwesi Johnson espouses a particular African-centred, religious iconographythat draws on the Rastafari faith to capture the black experience in London and assert an alternative cultural world-view. The representation of Christianity in diasporic African-Jamaican fiction is particularly interesting given the faith's paradoxical connection with black communities. Many afrocentric scholars discredit Christianity (despite its centrality in black culture) for its "desacralization of the African spiritual space,

\footnotetext{
${ }^{5}$ Cooper, Noises in the Blood, 13.
} 
that is, of African life, given the paramount importance of spirituality for African people. ${ }^{\prime 6}$ Many black writers nevertheless give credence to black churches and the instrumental role they have played in providing spiritual uplift, as well as a space of resistance. We see this represented in Afua Cooper's poem "The Upper Room," where the persona experiences spiritual liberation through the black church. For Silvera's character Maria, the black church is also a spiritual anchor that has helped her cope in her adoptive 'home', which has failed to provide her with the security that she expected. This re-imagining of Christianity by African-Jamaican writers speaks to the elasticity of an anti-colonial framework, which allows for multiplicity, even syncretism, rather than projecting a single epistemology.

\section{Community Activism and Pan-Africanism in Black Diasporic Fiction}

Given the pressing socio-economic issues facing black diasporic communities, it is not surprising to find authors of African descent taking up political themes and advocating for resistance. Many of the writers examined in this work turn to pan-Africanism as a way to articulate their activism and imagine social justice for African peoples. McKay's pan-Africanist vision in Home to Harlem, for example, is encoded in a conversation between Jake (African-American) and Ray (Afro-Caribbean immigrant) that highlights the importance of African continuity and group consciousness. Such solidarity among diasporic blacks, McKay suggests, can bolster political and cultural movements and serve as protection from the threat of cultural erasure. Joan Riley's The Unbelonging also offers a revisionist history through a pan-Africanist lens, dislodging notions of European cultural hegemony and centering neo-African civilization. Some other more contemporary writers also re-contextualize pan-Africanism in interesting ways. Female dub poets, for instance, rework internationalist discourse to speak to black women's everyday reality, thus moving beyond the patriarchal rhetoric of an exclusively race-based frame. Mandiela's appropriation of the works of key male internationalist figures is particularly illumi-

\footnotetext{
${ }^{6}$ Ama Mambo Mazama,"Afrocentricity and African Spirituality," Journal of Black Studies 33.2 (November 2002): 223.
} 
nating as she subverts power by reconstructing a language that formerly denied her experience.

Linton Kwesi Johnson also re-appropriates a Marxist discourse. In contrast to other internationalists who renounced Marxism for its failure to take into account the specifics of the colonial context, LKJ holds on to some of the tenets of Marxism, finding them useful for his analysis of black experience. In this way he is mindful of Frantz Fanon's warning that "Marxist analysis should always be slightly stretched every time we have to deal with the colonial problem.." Although working in an earlier period, McKay, too, heeds this advice. As a self-identified Marxist, McKay reveals his political ideals in many of his poems, in ways that highlight the intersections of race and labour exploitation. These kinds of modification are significant for resisting the common assumption that pan-Africanism is an essentialist construct.

Pan-Africanism, in accordance with a long, strong tradition of black-nationalist calls for black colonization, is often read as an idealized call for a return to Africa. By contrast, the writers I consider here demonstrate a clear awareness of the impossibility of any real return to a mythic African 'homeland'. Instead, they are more concerned with Africa as a spiritual location that offers them a cultural grounding from which to nurture their identities. This approach, which Amilcar Cabral calls re-africanization, ${ }^{8}$ enables a renegotiation of Caribbean consciousness and facilitates a symbolic linking of African-Jamaican visual artists, musicians, dancers, and, of course, writers, with an African past. Re-Africanization is a critical element in the struggle of Afro-Caribbean peoples to create spaces for the cultural expression of their Africanness despite the significant cultural disruptions of slavery and the ongoing realities of racism, cultural negation, and marginalization. For many Caribbean artists, the re-insertion of Africa is a critical component of their diasporic creativity. ${ }^{9}$ Cooper's

\footnotetext{
${ }^{7}$ Fanon, The Wretched of the Earth, 40.

${ }^{8}$ Cabral, "National Liberation and Culture," in Return to the Source: Selected Speeches of Amilcar Cabral (New York: Monthly Review Press, 1973): 39-56.

${ }^{9}$ See, for example, the dub poet and playwright d'bi young, who shuttles between Cape Town, South Africa, and Toronto; her migration to South Africa is a symbolic and embodied extension of Afua Cooper's call, as she makes physical journeys to the continent to further her artist production. Young's move to Africa also challenges the postmodern trivialization of black diasporic people's return to Africa as impossible nostalgia. The migratory impetus in young's art is emble-
} 
poem "My Piece," for instance, encapsulates this process of re-africanization in demanding reparations for peoples of African descent globally - not to fund a physical return to Africa but for material support that will allow them to carry Africa forth in their lives and cultural expression:

Yes I want my piece of that 20 million pounds

To make poems

To make songs

To write books

To make film

To make art

To give to freedom fighter. ${ }^{10}$

One can argue that black diasporic artists have long been at the centre of efforts to re-africanize understandings of transatlantic history, using their work, as they do, to rescue the past and recover Africa as a point of home, departure, and return. Their artistic imaginings of the continent are a means of deconstructing black diasporic identity and re-interpreting cultural signifiers from Africa. We see this effort, for example, in McKay's poem "Africa," in which he seeks to challenge distorted images of Africa and restore dignity to them. These types of creative expressions certainly trouble Gilroy's notion of Africa as an immaterial source for the African diaspora. Furthermore, seeking the past as a pathway to move forward also disrupts static European notions of modernity. As many of writers demonstrate, a recovery of their African past is essential to the consolidating of fragmented identity and the forging of community. As Claire Harris notes,

the return to history for origins, takes these writers to the West Indies first, then to Africa [...] an Africa mythologized as the 'mother', source of authenticity, wholeness and original innocence."

matic of the dialogic flows of African diasporic culture, including between the continent and the diaspora.

${ }^{10}$ Cooper, Memories Have Tongues, 83.

${ }^{11}$ Claire Harris, "Poets in Limbo," in Amazing Space: Writing Canadian Women Writing, ed. Shirley Neuman \& Smaro Kamboureli (Edmonton, Alberta: NeWest, 1986): 122. 
Carrera Suárez echoes this thought, pointing out that such a motherland provides "its daughters and sons in the diaspora with a sense of community and identity for survival. ${ }^{\text {"12 }}$

Memory serves as a critical portal through which African-Jamaican cultures are passed on and kept alive in the diaspora. Memory allows diasporic authors to remain connected to familial and cultural histories. In Silvera'sThe Heart Does Not Bend, oral history is offered through Mammy's Patwa narratives, which keep the spiritual discourse of Africa alive. Similarly, Cooper's poem "Africa Wailin'," in seeking to unite the community against police brutality, takes us on a spiritual journey to Africa. The writers do not offer a romanticized remembering of their pasts - they provide critical reflection. Afua Cooper and Joan Riley, for instance, allude to such historic events as the Jamaican labour riots during the mid-1930s, ${ }^{13}$ the Walter Rodney riot in the late $1960{ }^{14},{ }^{14}$ and Jamaican independence in $1962 .{ }^{15}$ These events are all critical moments in Jamaican cultural and political history, mapping the nation's decolonization struggles. McKay similarly reminds us of the often forgotten discourse of the freedom fighter Toussaint Louverture and the Haitian revolution. In the novel Home to Harlem, his character Ray explains:

"The world doesn't know", he continued, "how great Toussaint L'Ouverture really was. He was not merely great. He was lofty. He was good. The history of Hayti today might have been different if he had been allowed to finish his work. ${ }^{m 6}$

The need for Ray to explain this to his friend Jake underscores the overshadowing and/or omission of African peoples from world history. In this respect, the reclamation of memories can play an important role in re-centering African experience. As Mary Ann Chamberlain posits,

Memories are not only mediated but also censored, publicly and privately, officially and unofficially. The memories of minorities are $[\ldots]$ vulnerable to

${ }^{12}$ Isabel Carrera Suárez, "Absent Mother(Lands): Joan Riley's Fiction," in Motherlands: Black Women's Writing from Africa, the Caribbean and South Asia, ed. Susheila Nasta (London: Women's Press, 1990): 305 .

${ }^{13}$ Cooper, Memories Have Tongues, 19.

${ }^{14}$ Cooper, Copper Woman and Other Poems, 46.

${ }^{15}$ Riley, The Unbelonging.

${ }^{16}$ McKay, Home to Harlem, 133. 
such censoring and silencing. Equally immigrants are often expected to adapt to the new society. In this process, it must be assumed they are required to forget, or at least relegate, the past so that memory of what is here and now thus identification with the present becomes dominant. ${ }^{17}$

The writers in the present study certainly take up this role as preservers of an African-Jamaican cultural presence in new diasporic spaces. Not only do they refuse to censor their memories, they insist on telling them in their own voices.

\section{Black Feminism in Diasporic Writing}

A thread of black feminist discourse also weaves through the work of female Jamaican diasporic writers. One sees this discourse in the taking-up of themes such as mothering, sexuality, and childbirth and in reflections on the challenges of negotiating black female identity. These writers often problematize stereotypes about black women by presenting images of black female self-actualization through the prism of a diasporic/indigenous aesthetic and black nationalism. Their poems and fiction also offer a potent critique of the legacy of slavery and colonization in black communities in general, and its effect on black women in particular. Given the multiple oppressions faced by black women, these writers strive to encourage women of African descent to fight back; their literary activism is a means of resisting (neo)colonial, racial, and patriarchal structures and recovering black female selfhood.

Female diasporic authors celebrate the support offered by community building and the cultural continuity of dialogue across generations of women. Makeda Silvera, for example, creates a "safe space" (the kitchen ${ }^{18}$ ) "where black women's speech can be heard." ${ }^{\prime 1}$ Here the shared space of the kitchen consti-

${ }^{17}$ Mary Ann Chamberlain, "Transnational Families: Memories and Narratives," Global Network 4.3 (2004): 229 .

${ }^{18}$ The kitchen is a central site in African diasporic female literature - see, for instance, Paule Marshall's essay "The Making of a Writer: From the Poets in the Kitchen" (1983), which attributes her love of language and storytelling to her mother and other Bajan (Barbadian) women who, sitting around the kitchen table, effortlessly created narrative art; Marshall, Reena and Other Stories (New York: The Feminist Press, 1993): 3-12.

${ }^{19}$ Clarisse Zimra, "Righting the Calabash: Writing History in the Female Francophone Narrative," in Out of the Kumbla: Caribbean Women and Literature, ed. Carole Boyce Davies \& Elaine Fido Savory (Trenton NJ: Africa World Press, 1990): $15^{2}$. 
tutes a place in which black women can express their authentic selves; in this way it operates in parallel to McKay's "Congo Club." The kitchen frees Silvera's characters both of eurocentric intervention and male domination. In this intimate domestic space, African-Jamaican immigrant women offer their own narratives on a wide range of public and private matters such as child-rearing, abortion, domestic violence, marriage, and wider socio-economic and political issues in their new 'home'. At the same time, the kitchen space is one where traditional meals are prepared and 'stories of back home' are shared, grounding both the characters and reader in the distinctive meanings and cadences of Jamaican language and culture.

\section{The Next Generation}

Although dub poetry is no longer the dominant form of poetry in black diasporic communities (having been replaced by slam and spoken word), current writers of Jamaican descent continue to draw on a dub aesthetic in their work. The poet and dramatist d'bi young, for instance, uses dub stylistics in her artistic works of social criticism and political consciousness. young employs Jamaican creole as her primary means of expression, and African cosmology and black feminist discourse are central to her poems. ${ }^{20}$ She thereby continues the legacy of her dub foremothers. Her poem "tellin the stories yo" reads in much the same vein as poetry by Lillian Allen or Afua Cooper, alluding as it does to literary Sankofa and calling on contemporary poets to draw on their cultural wisdom and integrity:

Modern griots I charge you

to reflect truth

reflection

like yemaya/olokun

seeing her perfect Black self

in atlantic ocean waters

${ }^{20}$ Many of young's themes are similar to those of her Canadian and British counterparts, in that she deals with diasporic issues affecting the black community such as racial profiling and oppression. Much of her poetry also explores mothering and childbirth from a black feminist perspective. She diverges, however, from most of her earlier contemporaries in touching on taboo subjects such as homosexuality and uniquely infusing punk rock and Latin sounds into her work. 
where the bravest reside

modern griots I urge you to

reflect the truth

reflection. $^{21}$

And, as in Afua Cooper's poem "My Piece," young recognizes artistic expression as crucial to keeping ancestral connections alive in the diasporic world:

hip hopers

dub poets/spoken word artists

Playwrights/writers/actors/dancers/politicians

Painters

find the poetry that reflects integrity

find the poetry that reflects integrity

there is a world community

that you could give a shit about. ${ }^{22}$

On the topic of Christianity, however, young is more in step with the strong tone of exhortatory condemnation typical of Linton Kwesi Johnson. Her poem "bible and gun," for instance, rejects Christianity because of its role in the enslaving of black people:

blood sweat and tears

convert afrikans

brainwash di afrikans

his eye is on di sparrow

misogynist missionary work

what a insanity

inna di name of Christianity. ${ }^{23}$

young also injects a feminist discourse into her critique of Christianity, noting that in addition to religion the missionaries left behind a sexist and patriarchal ideology. (This part of young's critique is somewhat misleading, in that it assumes an Africa free of patriarchy and sexism prior to the arrival of the Christian missionaries.) In the concluding stanzas of this poem, young embraces an

\footnotetext{
${ }^{21}$ d'bi young, rivers... and other blackness... between us (Toronto: Women's Press, 2007): 30-32.

${ }^{22}$ young, rivers... and other blackness... between us, $3^{2}$.

${ }^{23}$ rivers... and other blackness... between us, 10.
} 
African-centred spirituality as a path to freeing black diasporic people from eurocentric hegemony:

I say rise up Black people rise up

Time to break dese chains

Our spirits have been living in capacity

Time to set dem free

Gimme mawue legua nu kwa

gimme Yoruba ochunyemoja

gimme akan ifa obatala

gimme di moon and di star

gimme di water and di plants

respect for all living life

gimme di people an di sun

afro-spiritual tradishun ${ }^{24}$

Here again, young's exploration of African spirituality relies on understandings that are somewhat problematic; in emphasizing Africans' connections to the environment she relies, to a certain extent, on an idealized sterotype of Africans as inherently naturalistic beings.

Nadine Williams, another rising poet of Jamaican descent who resides in Toronto, also exhibits many African-Jamaican aesthetic continuities, incorporating Patwa lexis and reggae, jazz, and gospel music in her performances. "Black Bwoi," for instance, uses both Patwa and a dancehall deejay vocal style and rhythm to address pervasive gang violence and the shootings of young black males and to plead for an end to the violence:

Black bwoi mi tyad fi weep fi yuh

tyad fi sih di yout dem a bun some weed fi yuh

trying desperately fi numb di pain weh dem feel fi yuh

mek dis year bi di change wih long fi sih innah yuh

strut bout town wid yuh books dem close tuh yuh

mek yuh weekend hang out bi wid family who care fi yuh

walk off from a bwoi who yuh tink a dis yuh

nuh mek wan nedda bredda or sistah miss yuh

just beg yuh memba she wih as a community love and care fi yuh mourn fi yuh. ${ }^{25}$

${ }^{24}$ young, rivers... and other blackness... between us, 10-11. 
Williams' words echo Afua Cooper's in their emphasis on how community plays a crucial nurtuing role for black people as they face socio-economic violence and police brutality. The poem also points to the importance of the black church, telling the imagined black male reader that the speaker is begging "pawsin deacon and prayah warriors fi storm hebbin fi yuh." ${ }^{26}$ The speaker represents mothers and other maternal figures, which is somewhat problematic, in that women are once again burdened with the responsibility of healing the community. The conclusion draws on a common Jamaican saying, advising young men to "just hold a seat and pene di message wih a try fi send tuhyuh Black bwoiwih love and care fi yuh."

In another poem, "Kerosene Lamp," Williams' speaker reflects on her function as storyteller in her rural neigbourhood in Jamaica, a role heightened by the absence of television in the community. The traditional oral griot role now includes printed children's stories.

Tank god seh by di kersene lamplight in a picturesque likkle district called

Juno Pen in St Mary Parish Jamaica West Indies

Mi loving grandfada would call mi when di sun guh dung

Fowl guh roos and peeny wally come out fi play

Mi can still hear him till dis very day

Come chile come read fi wih

Wid nuttin name television fi distracwih

Mi bredda cousins neighbahs granny and grandfada

Would gadda roun di kersene lamplight

Fi hear stories from Nancy Drew

Hardy boys or any adda books

weh di local library would produce. ${ }^{28}$

Williams' poem of family recollection captures the complex intersectionality of language and the heritage of culture passed on from generation to generation -

${ }^{25}$ Nadine Williams, A Poetic Journey... Pen On Fyah': Continuing the Journey from the Culmination of Series (Toronto: The author, 2011): 24.

${ }^{26}$ Williams, A Poetic Journey... Pen On Fyah', 24.

${ }_{27}^{27}$ 'Hold a seat...[to] pene di message' is a Jamaican expression advising a person to stop what they are doing for a moment and reflect on what has been said to them.

${ }^{28}$ Nadine Williams, Culmination of Marriage Between Me and My Pen (Toronto: The Author, 2008): 6 . 
whereby, as a gentle irony, the material read from betrays its US-American 'neocolonial' provenance. In the same poem, the narrator's grandfather reminds her of the importance of reading because of its ability to expand and develop vocabulary. In another irony, this affirmation of the power of literacy is couched entirely in the oral mode of Patwa:

If mi nevah listen tuh mi grandfada

Mi woulda nevah know how fi use words like

Elation fi happiness

Vindication fi dem finally clear up mi name

Substitution fi a mi a guh tek him place seen

Transpire fi dis is exactly weh a guh tek place

Proprietor instead of yuh sih dih ownah fi dih jint

Condiments instead of pass mi di ketchup peppah and vinigah

Likkle children tek heed when you're told dat yuh haffi

read fi at least 30 mins each and everyday

yah guh give tanks latah when yuh evolve into adults that can hold

an intelligent conversation. ${ }^{29}$

Williams' poetic reflections call to mind Jean 'Binta' Breeze's "I Poet," where she offers an account of the way she has been shaped by both the written and the oral contexts in which she grew up:

Ah was reading

Reading all de time

Fram book

Fram play

Framt.v.

Fram life

In odder words

Framyuh all...

Ah read all yuh poems

Ah read all yuh plays

Ah read all tea leaf, plum

Anytingwid a good story

Even if it didn't always have

A happy endin..$^{30}$

${ }^{29}$ Williams, Culmination of Marriage Between Me and My Pen, 6.

${ }^{30}$ Breeze, Spring Cleaning: Poems, 88-89. 
It is important to note, however, that while learning from metropolitan literary sources has typically been lauded in Caribbean cultural contexts (and the educational legacy established in the anglophone Caribbean was in many respects exemplary), recognition of oral traditions has been slow in coming. Williams articulates this in her reflection that it is only by mastering written English that the poet "can hold an intelligent conversation... [and] commands attention when you put pen to paper and open your mouth." ${ }^{31}$ For his part, McKay was bewildered when someone advised him to use Patwa in his work,

because to us who were getting an education in the English schools the Jamaican dialect was considered a vulgar tongue... All cultivated people spoke English, "straight English." ${ }^{2}$

Dub poetry and other largely oral poetic forms that are natural vehicles of folk sensibility have not infrequently been regarded as suspect by citizens, both white and black, who invest in proficiency in written literacy as the key to social mobility (a tension also found in American schools vis-à-vis afrocentricity and its ideological-linguistic outgrowth, Ebonics). Keenly aware of this, poets feel bound to protest the validity of their language choice, as Jean 'Binta' Breeze writes:

so doah I was well hurt inside

Wen yu all did sey

I wasn't no poet

I never mind

cause I sey I was a poet all de time

so I start write

an I thankful

to madda an fadda

dah ah fid read and love firs

fah I know

when writin

I poem

is you

all you. ${ }^{33}$

\footnotetext{
${ }^{31}$ Williams, Culmination of Marriage Between Me and My Pen, 6.

$3^{22}$ Claude McKay, My Green Hills of Jamaica (1975; Jamaica \& Trinidad: Heinemann Caribbean, 1979): 67 .
} 
It is a mark of the resilience of African-Jamaican cultural continuities that although Breeze and Williams both recognize these tensions they choose to celebrate oral culture through their poetic use of Patwa.

As a final example of the new generation of diasporic African-Jamaican writers, I turn to the UK novelist Zadie Smith. Smith, who is of Jamaican and British parentage, has an impressive body of work that takes up many of the same themes as her diasporic coevals. Her work, like theirs, is largely concerned with the familial and wider social experiences of immigrant black communities. One difference is that, rather than focusing solely on the AfricanJamaican community, Smith depicts the lives of a wider range of ethnicities including Muslims and Bengalis. Most of the analysis of White Teeth that I have accessed offers a primarily postmodern reading of the text. ${ }^{34}$ Such a reading tends to bypass the notion of origins in favour of stressing multiple identities and hybridity in the country of residence, and a sometimes idealistic vision of multiculturalism. ${ }^{35}$ The African-Jamaican aesthetic underpinnings of the novel can all too often go unremarked. And as any affiliation with origin is interpreted as necessarily essentializing, Smith's protagonist Irie's leaving behind of the trappings of her Jamaican heritage and embrace of multiculturalism are understood as a move towards freedom. Irie's experience is quite unlike that of Riley's character Hyacinth, who does not find multiculturalism a path to social freedom - she is unwilling to let go of her Jamaican background, which reluctance makes it harder for her to find acceptance in English society.

Despite Smith's characterization of Irie, one cannot miss the vestiges of African-Jamaican aesthetic continuities in her novel. For one, it shows a large Caribbean immigrant presence and the deterritorialization of Caribbean culture into British society provides the work with African-Jamaican qualities. At

\footnotetext{
${ }^{33}$ Breeze, Spring Cleaning: Poems, 89.

${ }^{34}$ Molly Thompson, “'Happy Multicultural Land'? The Implications of an 'excess of belonging' in Zadie Smith's White Teeth,” in Write Black, Write British: From Post Colonial to Black British Literature, ed. Kadija Sesay (London: Hansib, 2005): 122-40; Prjo Ahokas, "Transcending Binary Divisions: Constructing a Postmodern Female Urban Identity in Louise Erdrich's The Antelope Wife and Zadie Smith's White Teeth," in Sites of Ethnicity: Europe and the Americas, ed. William Boelhower, Rocío G. Davis \& Carmen Birkle (Heidelberg: Winter, 2004): 115-29.

${ }^{35}$ Smith herself has admitted to idealizing British race relations in her novel; Anthony Quinn, "White Teeth by Zadie Smith," New York Times Book Review (30 April 200o): 7-8.
} 
the same time, Smith attempts to escape fixed notions of identity, suggesting that she sees a danger in relying on culture and ethnicity in shaping one's selfdefinition in contemporary, multicultural society. Ironically, this postmodernist position is somewhat narrow, inasmuch as it does not acknowledge how transnational cultural flows can in fact provide agency and assist in diasporic identity-formation. Smith does nod to this in the relationship between Irie and her Jamaican grandmother Hortense, who is instrumental in providing her with knowledge about her Caribbean heritage on her journey towards an integrated identity. ${ }^{36}$ The relationship indicates how diasporic identity tied to home cultures does not always translate into static notions of self-identification.

Indeed, the writers under examination have negotiated between their local cultures and metropolitan canonical forms to create a new and alternative literary discourse. What is significant here is these writers' ability to successfully occupy the in-between spaces of the diaspora without having to assimilate to the dominant cultural norms and without having to relinquish their cultural identity entirely. Other cultural traces that are identifiable in Smith's work include taking up the common diasporic themes of contested citizenship and British race relations. On this count, Smith's critique of the British Empire and the legacy of colonialism reads no differently from earlier Caribbean works such as Lamming's The Immigrants (1954) and Selvon's The Lonely Londoners (1956). Smith's use of storytelling to inform a younger generation about postwar Caribbean migrant experiences, along with the naming of her protagonist "Irie," a term meaning 'everything is alright' in Rastafarian speech, is also indicative of her links to an African-Jamaican and Caribbean aesthetic.

Furthermore, and significantly, in White Teeth Smith positions Jamaican nation language as central within the metropolis as opposed to its usual relegation to marginal status. To express the multiplicity of British multiculturalism, Jamaican Patwa is used by British youths belonging to various different ethnic groups. In her description of the Millet street gang, for example, Smith writes that its members speak "a strange mix of Jamaican Patois, Bengali Guajarati

\footnotetext{
${ }^{36}$ This granddaughter-grandmother relationship stands in contradiction to Patricia Goldblatt's observation that Irie "proceeded on her own path of self-recognition and identity"; Goldblatt, "'School is Still the Place': Stories of Immigration and Education," Multicultural Review 13.1 (Spring 2004): 53 .
} 
and English." ${ }^{37}$ Smith's creolization of the London metropolis is reminiscent of Louise Bennett's popular poem "Colonization in Reverse," in which Bennett "ironically superimposes the midcentury Jamaican migration to England on the three hundred year English settlement of Jamaica": $3^{8}$

Dem a pour out a Jamaica,

Everybody future plan

Is fe get a big-time job

An settle in de motherlan.

What a islan! What a people!

Man an woman, ole an young

Jussa pack dem bag an baggage

An tun history upside dung $!^{39}$

Bennett's observations speak to an African presence and cultural memory unwilling to remain contained by or left behind in the homeland; equally, they demonstrate how indigenous knowledges can extend beyond borders, not only challenging dominant discourse but also serving as a cultural cushion for those forced to negotiate new identities.

In the final analysis, Smith, young, and Williams all demonstrate that the newer generations of diasporic writers have maintained continuity with their Jamaican roots and heritage. At the same time they probe deep into the nature of identity and engaging with other local diasporic cultures. d'bi young, for example, offers anti-homophobia rhetoric and a fusion of non-black musical forms in her dub aesthetic, while Nadine Williams employs African-American gospel rhythms and Zadie Smith captures the cultural alliances between the Caribbean community and other ethnic and racialized communities as they challenge the hegemony of white British society.

This work has explored the ways in which African-Jamaican writers, despite cultural marginalization and postmodernist assumptions about fragmented selves and idealized memories of Africa, ${ }^{40}$ have maintained continuity with

\footnotetext{
${ }^{37}$ Zadie Smith, White Teeth (New York: Random House, 2000): 197.

${ }^{38}$ Jahan Ramazani, The Hybrid Muse: Postcolonial Poetry in English (Chicago: U of Chicago P, 2001): 126 .

39 Bennett, Jamaica Labrish, 179; Selected Poems, ed. Morris, 106.

${ }^{40}$ Simon Gikandi, Writing in Limbo (Ithaca NY: Cornell U P, 1992): 95.
} 
their African-Jamaican roots in diasporic spaces. Rather than prescribing a return to Africa to recover "natural African meanings, ${ }^{\text {"11 }}$ they express a symbolic and spiritual connection to Africa and trace the many ways their AfricanJamaican cultural heritage has been influenced by a West African legacy.

The poems, plays, and novels of African-Jamaican diasporic writers can be read as cartographies of home and away, memory, shared histories, new trajectories, and as an articulation of the elasticity of cultural frames of reference over time. This literature confirms James Clifford's proposition that the fluidity of cultural transmission is evident in the way culture is both rooted and routed over various journeys through history. ${ }^{42}$ Readers are enjoined to witness the interesting, complex, and ongoing conversations among black writers and the larger social African diaspora as they map out these cultural roots and routes. It is a dialogue of creative vision that speaks of personal, communal, and national history,

because the need to belong to a community continues even as the community transforms and the need to identify with a nation continues even as the borders of the nation are constantly redefined. ${ }^{43}$

Finally, I hope this work has demonstrated the ways in which incorporating an anti-colonial frame opens up space for new and multiple readings of black literature by de-privileging eurocentric discourse and re-centering local cultures, thus celebrating a liberatory creativity based on the richness of AfricanJamaican indigenous knowledges.

${ }^{41}$ Gikandi, Writing in Limbo, 196.

${ }^{42}$ James Clifford, "Traveling Cultures," in Cultural Studies, ed. Lawrence Grossberg, Cary Nelson \& Paula Treichler (New York: Routledge, 1992): 96-116.

${ }^{43}$ Patrick Taylor, "Post-Colonial Encounters: Paule Marshall's 'Widow's Praisesong' and George Lamming's 'Daughter's Adventure'," in "And the Birds Began to Sing": Religion and Literature in Post-Colonial Literatures, ed. Jamie Scott (Cross / Cultures 22; Amsterdam \& Atlanta G A: Rodopi, 1996): 205 . 


\section{- Works Cited -}

Agard, John. Mangoes and Bullets (London: Serpent's Tail, 1990).

Agarwal, Supriya, \& Jasbir Jain. Shifting Homelands, Travelling Identities (New Delhi: Sterling, 2008).

Ahokas, Prjo. "Transcending Binary Divisions: Constructing a Postmodern Female Urban Identity in Louise Erdrich's The Antelope Wife and Zadie Smith's White Teeth," in Sites of Ethnicity: Europe and the Americas, ed. William Boelhower, Rocío G. Davis \& Carmen Birkle (Heidelberg: Winter, 2004): 115-29.

Alexander, Simon A. James. Mother Imagery: The Novels of Afro-Caribbean Woman (Columbia: U of Missouri P, 2001): 96-135.

Allen, Lillian. "De Dub: Renegades in a One Poem Town," This Magazine (December 1987-January 1988): 14-21.

_. "Poems are not meant to lay still," in The Other Woman: Women of Colour in Contemporary Canadian Literature, ed. Makeda Silvera (Toronto: Sister Vision, 1995): 256-57.

—.Revolutionary Tea Party (Verse to Vinyl, 1986).

—. Riddim and Hardtimes (Toronto: Domestic Bliss, 1982).

—.Women Do This Every Day: Selected Poems of Lillian Allen (Toronto: Women's Press, 1993).

__. "A Writing of Resistance: Black Women's Writing in Canada," in In the Feminine: Women and Words, ed. Ann Dybikowski et al. (Edmonton, Alberta: Longspoon, 1985): 63-67.

Alleyne, Mervyn. Africa: Roots ofJamaican Culture (Chicago: Research Associates School Times Publications, 1996).

Altink, Henrice. "More than Producers and Reproducers: Jamaican Slave Women's Dance and Song," in Beyond the Blood, the Beach and the Banana: New Perspectives in Caribbean Studies, ed. Sandra Courtman (Kingston, Jamaica: Ian Randle, 2004): 71-90.

Androutsopoulos, Jannis, \& Arno Scholz. "Spaghetti Funk: Appropriations of Hip-Hop Culture and Rap Music in Europe," Popular Music and Society 26.4 (2003): 463-79. 
Anthias, Floya. “Evaluating 'Diaspora': Beyond Ethnicity?” Sociology 32.3 (August 1998): 557-80.

Asante, Molefi Kete. "African Elements in African American English," in Africanisms in American Culture, ed. Joseph E. Holloway (Bloomington: Indiana UP, 1990): 65-81.

— _ \& Emeka Nwadiora. Spear Masters: An Introduction to African Religion (New York: UP of America, 2007).

Asante, S.K.B. Pan African Protest: West Africa and the Italo-Ethiopia Crisis 1934-1941 (London: Longman, 1977).

Baker, Houston A., Jr. Blues, Ideology and Afro-American Literature: A Vernacular Theory (Chicago: U of Chicago P, 1984).

—.Modernism and the Harlem Renaissance (Chicago: U of Chicago P, 1987).

Bannerji, Himani. Dark Side of the Nation: Essays on Multiculturalism, Nationalism and Gender (Toronto: Canadian Scholars Press, 2000).

Baraka, Amiri [LeRoi Jones]. Blues People: Negro Music in White America (New York: Morrow Quill, 1965).

Barrett, Leonard E. The Rastafarians (Boston MA: Beacon, 1997).

Baugh, Edward. "Poetry (The Caribbean)," in The Routledge Encyclopedia of Post Colonial Literature, ed. Eugene Benson \& Leonard W. Conolly (New York: Routledge): 1241-44.

Beckford, Sharon. "Taking a Piece of the Past with Us: Jamaica-Canadian Fruits of Migration in Makeda Silvera's Heart Does Not Bend," in Jamaica in the Canadian Experience: A Multiculturalizing Presence, ed. Carl E. James \& Andrea Davis (Halifax, Nova Scotia \& Winnipeg, Manitoba: Fernwood, 2006): 84-96.

Beckles, Hilary M. “'War Dances': Slave Leisure and Anti-Slavery in the British Colonised Caribbean," in Working Slavery, Pricing Freedom: Perspectives from the Caribbean, Africa, and the African Diaspora, ed. Verene A. Shepherd (New York: Palgrave, 2001): 223-46.

Beckwith, Martha Warren.Jamaican Proverbs (Poughkeepsie NY: Vassar College, 1925).

Bell, Bernard W. The Contemporary African American Novel: Its Folk Roots and Modern Literary Branches (Amherst: $\mathrm{U}$ of Massachusetts P, 2004).

Bennett, Louise. Aunty Roachy Seh (Kingston, Jamaica: Sangster's, 1993).

—. "Introduction" to Julie Pearn, Poetry in the Caribbean (London: Hodder \& Stoughton, 1985): iii-iv.

_. Jamaica Labrish (Kingston, Jamaica: Sangster's, 1966).

—. Selected Poems, ed. Mervyn Morris (Kingston, Jamaica: Sangster's, 1983).

Boehmer, Elleke. "Stories of Women and Mothers: Gender and Nationalism in the Early Fiction of Flora Nwapa," in Motherlands: Black Women's Writing from Africa, the Caribbean and South Asia, ed. Susheila Nasta (London: Women's Press, 1991):3-23. 
Bonnett, Aubrey W. "The West Indian Diaspora to the USA: Remittances and Development of the Homeland," in Forum on Public Policy (2006), http://www.forumon publicpolicy.com/archivesumo 7/bonnett.pdf (accessed 12 September 2013).

Brathwaite, Edward Kamau. "The African Presence in Caribbean Literature" (1974), in Brathwaite, Roots (1986; Ann Arbor: U of Michigan P, 1993): 190-258.

- The Arrivants: A New World Trilogy (London: Oxford UP, 1981).

C.Contradictory Omens: Cultural Diversity and Integration in the Caribbean (Mona, Jamaica: Savacou, 1974).

—_. "English in the Caribbean: Notes on Nation Language and Poetry," in English Literature: Opening Up the Canon, ed. Leslie A. Fiedler \& Houston A. Baker Jr. (Baltimore MD: Johns Hopkins UP, 1981): 15-53.

- Folk Culture of the Slaves in Jamaica (London \& Port of Spain: New Beacon, 1970).

- History of the Voice: The Development of Nation Language in Anglophone Caribbean Poetry (London \& Port of Spain: New Beacon, 1984).

_. [L. Edward Brathwaite]. "Jazz and the West Indian Novel," Bim 11/44 (JanuaryJune 1967): 275-84; 12/45 July-December 1967): 39-51; 13/46 (January-June 1968): 115-26; repr. in Edward Kamau Brathwaite, Roots (1986; Ann Arbor: U of Michigan P, 1993): 55-110.

Braziel, Jana E., \& Anita Mannur. "Nation, Migration, Globalization: Points of Contention in Diaspora Studies," in Theorizing Diaspora, ed. Jana E. Braziel \& Anita Mannur (Malden MA: Blackwell, 2003): 1-21.

Breeze, Jean 'Binta'. Riddym Ravings and Other Poems (London: Race Today Publications, 1988).

- Spring Cleaning: Poems (Reading: Virago, 1992).

Brodber, Erna. Myal (London: New Beacon, 1988).

Brown, Ethelred, \& Eugene Kinckle Jones. "West Indian-American Relations: A Symposium," Opportunity 4 (November 1926): $355^{-56}$.

Brown, Lloyd. West Indian Poetry (Boston M A: Twayne, 1978).

Brown-Guillory, Elizabeth, ed. Middle Passages and the Healing Place of History: Migration and Identity in Black Women's Literature (Columbus: Ohio State UP, 2006).

Brown Spencer, Elaine A. "Spiritual Politics: Politicizing the Black Church Tradition in Anti-Colonial Praxis," in Anti-Colonialism and Education: The Politics of Resistance, ed. George J. Sefa Dei \& Arlo Kempf, foreword by Molefi Kete Asante (Rotterdam: Sense, 2006): 107-27.

Bucknor, Michael A. "Postcolonial Crosses: Body-Memory and Inter-Nationalism in Caribbean / Canadian Writing” (doctoral dissertation, University of Western Ontario, 1998). 
Burnett, Michael.Jamaican Music (Oxford: Oxford UP, 1982).

Burnett, Paula, ed. Penguin Book of Caribbean Verse in English (Harmondsworth: Penguin, 1986).

Burton, Richard D.E. Afro-Creole: Power, Opposition and Play in the Caribbean (Ithaca NY: Cornell UP, 1997).

Cabral, Amilcar. "National Liberation and Culture," in Return to the Source: Selected Speeches of Amilcar Cabral (New York: Monthly Review Press, 1973):39-56.

Carr, Brenda. “'Come Mek Wi Work Together': Community Witness and Social Agency in Lillian Allen's Dub Poetry," ARIEL: A Review of International English Literature 29.3 (July 1998): 7-40.

Carrera Suárez, Isabel. “Absent Mother(Lands): Joan Riley's Fiction," in Motherlands: Black Women's Writing from Africa, the Caribbean and South Asia, ed. Susheila Nasta (London: Women's Press, 1990): 290-309.

Caesar, Burt. "Linton Kwesi Johnson talks to Burt Caesar at Sparkside Studios, Brixton, London, 11 June 1996," Critical Quarterly 38.4 (December 1996): 64-77.

Campbell, George. "History Makers," in Campbell, First Poems (1945; New York: Garland, 1981):32.

Campbell, Mark. "Indigenous Knowledge in Jamaica: A Tool of Ideology in a Neo-Colonial Context," in Anti-Colonialism and Education: The Politics of Resistance, ed. George J. Sefa Dei \& Arlo Kempf, foreword by Molefi Kete Asante (Rotterdam: Sense, 2006): 193-242.

Cartey, Wilfred G. Black Images (New York: Teachers College Press, 1970).

Cassidy, Frederick G., \& Robert B. Le Page. Dictionary of Jamaican English (Mona, Kingston: U of the West Indies P, 2nd ed. 2002).

Césaire, Aimé. Discourse on Colonialism, tr. Haakon Chevalier (Discours sur le colonialisme, 1950; New York: Monthly Review Press, 1972).

-Discourse on Negritude: Miami 1987 (Fort de France: Conseil général de la Martinique, Bureau de la Communication et des Relations avec la Presse, 2003).

__ . "Entretien avec Aimé Césaire, Paris, 1975, à l'occasion de la réédition de Tropiques," in Jacqueline Leiner, Aimé Césaire: le terreau primordial (Études littéraires françaises; Tübingen: Gunter Narr, 1993): 111-43.

Chamberlain, Mary Ann. "Transnational Families: Memories and Narratives," Global Network 4.3 (2004): 227-41.

Chamberlin, Edward. Come Back to Me My Language: Poetry and the West Indies (Urbana \& Chicago: U of Illinois P, 1993).

Chambers, Douglas B. "The Black Atlantic: Theory, Method, and Practice," in The Atlantic World, 1450-2000, ed. Toyin Falola \& Kevin D. Roberts (Bloomington: Indiana UP, 2008): 151-75. 
Christian, Barbara. "The Race for Theory" (1987), in The Black Feminist Reader, ed. Joy James \& Tracy Denean Sharpley-Whiting (Malden MA \& Oxford: Blackwell, 1999): 11-22. Originally in Cultural Critique 6 (Spring 1987): 51-63.

Clark, VèVè A. "Developing Diaspora Literacy and Marasa Consciousness," Theatre Survey 50.1 (May 2009): 9-18.

Clarke, George Elliott. "Must All Blackness Be American? Locating Canada in Borden's 'Tightrope Time,' or Nationalizing Gilroy's The Black Atlantic," Canadian Ethnic Studies 28.3 (1996): 56-72.

Clarke, John Henrik. "Pan Africamism: A Brief History of an Idea in the African World," The Third World First 1.2 (1990): 9-24.

Cliff, Michelle. No Telephone to Heaven (New York: Vintage. 1989).

Clifford, James. "Traveling Cultures," in Cultural Studies, ed. Lawrence Grossberg, Cary Nelson \& Paula Treichler (New York: Routledge, 1992): 96-116.

Collier, Gordon. '“At the Gate of Cultures' of the New World: Religion, Mythology and Folk Belief in West Indian Poetry," in "And the Birds Began to Sing”: Religion and Literature in Post-Colonial Cultures, ed. Jamie Scott (Cross / Cultures 22; Amsterdam \& Atlanta GA: Rodopi, 1996): 227-49.

Collins, Patricia Hill. Black Feminist Thought: Knowledge, Consciousness and the Politics of Empowerment (New York \& London: Routledge, 2000).

Cooper, Afua. Copper Woman and Other Poems, foreword by Neil Armstrong (Toronto: Natural Heritage, 2006).

—. "Finding My Voice," in Caribbean Women Writers: Essays From the First International Conference, ed. Selwyn R. Cudjoe (Wellesley MA: Calaloux, 1990): 301305 .

-Memories Have Tongues (Toronto: Sister Vision, 1982).

—. "My Piece," in Worlds of Fire (CD; Toronto: Soundmind Production, 2002).

— ed. Utterances and Incantations: Women, Poetry and Dub (Toronto: Sister Vision, 1999).

Cooper, Carolyn. "Afro-Jamaican Folk Elements in Brodber's Jane and Louisa Will Soon Come Home," in Out of Kumbla: Caribbean Women and Literature, eds. Carole Boyce Davies \& Elaine Savory Fido (Trenton NJ: Africa World Press, 1990): 279-89.

-Noises in the Blood: Orality, Gender and the 'Vulgar' Body of Jamaican Popular Culture (Durham NC: Duke UP, 1995).

"Proverb as Metaphor in the Poetry of Louise Bennett," Jamaica Journal 17.2 (May 1984): 21-24.

. "Race and the Cultural Politics of Self-Representation: A View from the West Indies," Research in African Literatures 27.4 (Winter 1987): 97-105. 
—_. "Something Ancestral Recaptured': Spirit Possession as Trope in Selected Feminist Fictions of the African Diaspora," in Motherlands: Black Women's Writing from the Africa, the Caribbean, and South Asia, ed. Susheila Nasta (New Brunswick NJ: Rutgers UP, 1992): 64-87.

- Sound Clash: Jamaican Dancehall Culture at Large (New York: Palgrave Macmillan, 2004).

—. “That Cunny Jamma Oman': The Female Sensibility in the Poetry of Louise Bennett," Bulletin of Eastern Caribbean Affairs (Barbados) 11.1 (March-April 1985): 1327.

Cooper, Wayne. Claude McKay: Rebel Sojourner in the Harlem Renaissance (New York: Schocken, 1990).

Courtman, Sandra, ed. The Society for Caribbean Studies Annual Conference Papers, vol. 1 (2000): online.

Cramer, Louise. "Songs of West Indies Negroes in the Canal Zone," California Folklore Quarterly 15.3 (July 1946): 243-72.

Crawford, Charmaine. "African-Caribbean Women, Diaspora and Transnationality," Canadian Woman Studies Journal/Cahiers de la femme canadienne 23.2 (Winter 2004): 97-103.

— . "Sending Love in a Barrel: The Making of Transnational Caribbean Families in Canada," Canadian Woman Studies Journal/Cahiers de la femme canadienne 22.3-4 (Spring-Summer 2003): 104-109.

Cundall, Frank, \& Izett Anderson. Jamaica Proverbs and Sayings (Shannon: Irish UP, 1972).

Daly, Mary. Gyn/Ecology: The Metaethics of Radical Feminism (Boston MA: Beacon, 1978).

Dance, Daryl Cumber. Folklore from Contemporary Jamaicans (Knoxville: U of Tennessee $\mathrm{P}, 1985)$.

Danticat, Edwidge. Breath, Eyes, Memory (New York: Vintage, 1994).

Dash, J. Michael. "Marvelous Realism - The Way Out of Negritude," Caribbean Studies 13.4 (January 1974): 57-70.

Davies, Carole Boyce, \& Elaine Fido Savory, ed. Out of the Kumbla: Caribbean Women and Literature (Trenton NJ: Africa World Press, 1990).

Davis, Andrea. "Hegemony of the Spirit: Black Women's Resistance and Healing through African Diasporic 'Counter Cultures of Modernity' in Selected African Caribbean and African American Women's Writing” (doctoral dissertation, York University, 2002).

— . "Translating Narratives of Masculinity Across Borders: A Jamaican Case Study," Caribbean Quarterly 52.2-3 (June-September 2006): 22-38. 
Dawes, Kwame. Natural Mysticism: Towards a New Reggae Aesthetics (Leeds: Peepal Tree, 1999).

_. Talk Yuh Talk: Interviews with Anglophone Caribbean Poets (Charlottesville: UP of Virginia, 2001).

Dei, George J. Sefa. "African Development: The Relevance and Implications of 'Indigenousness," in Indigenous Knowledges in Global Contexts: Multiple Readings of Our World, ed. George J. Sefa Dei, Budd L. Hall \& Dorothy Goldin Rosenberg (Toronto: U of Toronto P, 2000): 70-88.

- Rethinking the Role of Indigenous Knowledges in the Academy (NALL Working Paper 58, 2002).

__. "Spiritual Knowing and Transformative Learning," in Expanding the Boundaries of Transformative Learning: Essays on Theory and Praxis, ed. E.V. O'Sullivan, A. Morrell \& M.A. O'Connor (New York: Palgrave, 2002): 121-34.

_ \& Alireza Asgharzadeh. "The Power of Social Theory: Towards an Anti Colonial Discursive Framework," Journal ofEducational Thought 35.3 (2001): 297-323.

Dillinger. "Natty Dread a the General," YouTube (13 August 2012), http://www.youtube .com/watch?v=bg-wFikEYcM (accessed 20 July 2014).

Dixon, Melvin. "Rivers Remembering Their Source: Comparative Studies in Black Literary History - Langston Hughes, Jacques Roumain, and Négritude" (1979), in Melvin Dixon Critical Reader, ed. Justin A. Joyce \& Dwight A. McBride (Jackson: UP of Mississippi, 2006): 30-51. Originally in Afro-American Literature: The Reconstruction of Instruction, ed. Dexter Fisher \& Robert B. Stepto (New York: MLA, 1979): 25-43.

Donnell, Alison. "Contradictory (W)omens?: Gender Consciousness in the Poetry of Una Marson" (1996), in The Routledge Reader in Caribbean Literature, ed. Alison Donnell \& Sarah Lawson Welsh (London: Routledge, 1996): 187-93.

_ \& Sarah Lawson Welsh. "Introduction" to The Routledge Reader in Caribbean Literature, ed. Alison Donnell \& Sarah Lawson Welsh (London: Routledge, 1996): 27-40.

Drake, St Clair. "Diaspora Studies and Pan-Africanism," in Global Dimensions of the African Diaspora, ed. Joseph E. Harris (Washington DC: Howard UP, 1982): 352-74.

Dubey, Madhu. Black Women Novelists and the Nationalist Aesthetic (Bloomington: Indiana UP, 1994).

Duncan, Carol B. This Spot of Ground: Spiritual Baptists in Toronto (Waterloo, Ontario: Wilfrid Laurier UP, 2008).

Edwards, Nadi. "States of Emergency: Reggae Representations of the Jamaican Nation State," Social and Economic Studies 47.1 (March 1998): 21-32.

Elabor-Idemudia, P. "The Retention of Knowledge of Folkways as a Basis of Resistance," in Indigenous Knowledges in Global Contexts: Multiple Readings of Our World, ed. 
George J. Sefa Dei, Budd L. Hall \& Dorothy Goldin Rosenberg (Toronto: U of Toronto P, 2000): 102-19.

Fals Borda, Orlando. "Science and the Common People," Journal of Social Studies 11 (1981): $1-21$.

Fanon, Frantz. Black Skin, White Masks, tr. Charles Lam Markmann (Peau noire, masques blancs, 1952; tr. 1967; New York: Grove, 2004).

- The Wretched of the Earth, tr. Constance Farrington, preface by Jean-Paul Sartre (Les Damnés de la terre, 1961; New York: Grove, 1963).

Farred, Grant. 'You Can Go Home Again, You Just Can't Stay: Stuart Hall and the Caribbean Diaspora," Research in African Literatures 27.4 (Winter 1996): 28-48.

Ferly, Odile. A Poetics of Relation: Caribbean Women Writing at the Millennium (New York: Palgrave Macmillan, 2012).

Forbes, Curdella. "Redeeming the Word: Religious Experience as Liberation in Erna Brodber's Fiction," Postcolonial Text 3.1 (2007): 1-19.

Ford-Smith, Honor. Lionheart Gal: Life Stories of Jamaica Women (Toronto: Sister Vision, 1987).

Fryer, Peter. Black People in the British Empire: An Introduction (London: Pluto, 1988).

Gadsby, Meredith M. Sucking Salt: Caribbean Women Writers, Migration, and Survival (Columbia: U of Missouri P, 2006).

Garvey, Marcus. Philosophy and Opinions of Marcus Garvey, ed. Amy Jacques Garvey (New York: Atheneum, 1982).

Giddens, Anthony. The Consequences of Modernity (Stanford CA: Stanford UP, 1990).

Gikandi, Simon. Writing in Limbo (Ithaca NY: Cornell UP, 1992).

Gilkes, Michael. The West Indian Novel and Its Background (Boston M A: Twayne, 1986).

Gilroy, Paul. The Black Atlantic: Modernity and Double Consciousness (Cambridge MA: Harvard UP, 1993).

Glissant, Édouard. Caribbean Discourse: Selected Essays, sel., ed. \& tr. J. Michael Dash (CARAF Books; Charlottesville: UP of Virginia, 1989).

Goldblatt, Patricia. "'School is Still the Place': Stories of Immigration and Education," Multicultural Review 13.1 (Spring 2004): 49-54.

Goodison, Lorna. Controlling the Silver (Urbana \& Chicago: U of Illinois P, 2005).

Goudie, Sean X. "New Regionalisms: US -Caribbean Literary Relations," in A Companion to American Literary Studies, ed. Caroline Levander \& Robert Levine (Chichester: Wiley-Blackwell, 2011): 310-14.

Gourdine, Angeletta K.M. The Difference Place Makes: Gender, Sexuality, and Diaspora Identity (Columbus: Ohio State UP, 2002). 
Gross, Jason. "Interview with Linton Kwesi Johnson," Perfect Sound Forever: Online Music Magazine (1997), http://www.furious.com/perfect/lkj.html (accessed 20 September 2011).

Guano, Emanuela. "Revival Zion: An Afro-Christian Religion in Jamaica," Anthropos 89 (1994): 517-28.

Guarnizo, Luis Eduardo, Arturo I. Sánchez \& Elizabeth M. Roach. "Mistrust, Fragmented Solidarity, and Transnational Migration: Colombians in New York City and Los Angeles," Ethnic and Racial Studies 22.2 (1999): 367-96.

Habekost, Christian. Verbal Riddim: The Politics and Aesthetics of African Caribbean Dub Poetry (Cross / Cultures 10; Amsterdam \& Atlanta GA: Rodopi, 1993).

Hall, Stuart. "Cultural Identity and Diaspora," in Identity: Community, Culture, Difference, ed. Jonathan Rutherford (London: Lawrence \& Wishart, 1990): 222-37.

__. "Negotiating Caribbean Identities," New Left Review 209 (1995): 3-14.

Harris, Claire. "Poets in Limbo," in Amazing Space: Writing Canadian Women Writing, ed. Shirley Neuman \& Smaro Kamboureli (Edmonton, Alberta: NeWest, 1986): 11525 .

-Fables From the Women's Quarter (Stratford, Ontario: Williams-Wallace, 1984).

Hathaway, Heather. Caribbean Waves: Relocating Claude McKay and Paule Marshall (Bloomington: Indiana UP, 1999).

Ho, Christine G.T., \& Keith Nurse. Globalisation, Diaspora and Caribbean Popular Culture (Kingston, Jamaica: Ian Randle, 2005).

Hodge, Merle. "Challenges of the Struggle for Sovereignty: Changing the World versus Writing Stories," in Caribbean Women Writers: Essays from the First International Conference, ed. Selwyn R. Cudjoe (Wellesley MA: Calaloux, 1990):202-208.

Hodges, Hugh. Soon Come: Jamaican Spirituality, Jamaican Poetics (Charlottesville: UP of Virginia, 2008).

Hondagneu-Sotelo, Pierrette, \& Ernestine Avila. “I'm Here, but I'm There': The Meanings of Latina Transnational Motherhood," Gender and Society 11.5 (1997): 546-71.

hooks, bell. Feminist Theory: From Margin to Center (Boston MA: South End, 1984).

-. Outlaw Culture Resisting Representation (New York: Routledge, 1994).

Hopkinson, Nalo. Brown Girl in the Ring (New York: Warner, 1998).

Hurston, Zora Neale. Moses, Man of the Mountain (1939; New York: HarperPerennial, 1991).

Hussain, Ahmede. "In Conversation with Benjamin Zephaniah," Black and Gray Blog, http://ahmedehussain.blogspot.ca/2007/01/in-conversation-with-benjamin-zepha niah.html (accessed 16 September 2011).

Hyatt, Charles. When Me Was a Boy (Kingston: Institute of Jamaica Press, 1989). 
Igweonu, Kene. "Interculturalism Revisited: Identity Construction in African and African-Caribbean Performance," in Trends in Twenty-First Century African Theatre and Performance, ed. Kenechukwu Igweonu (Amsterdam: Rodopi, 2011): 61-84.

James, C.L.R. "Appendix: From Toussaint L'Ouverture to Fidel Castro," in James, The Black Jacobins: Toussaint L'Ouverture and the San Domingo Revolution (1938; New York: Vintage, rev. ed. 1963): 391-418.

James, Winston. "Becoming the People's Poet: Claude McKay's Jamaican Years, 18891912," Small Axe 13/7.1 (March 2003): 17-45.

- A Fierce Hatred of Injustice: Claude McKay's Jamaica and His Poetry of Rebellion (London: Verso, 2000).

Jarrett-Macauley, Delia. The Life of Una Marson 1905-1965 (Manchester: Manchester UP, 1998).

Jekyll, Walter.Jamaican Song and Story (1907; Mineola NY: Dover, 1966).

Jenkins, Lee M. The Language of Caribbean Poetry: Boundaries of Expression (Gainesville: UP of Florida, 2004).

Johnson, Linton Kwesi. Dread, Beat and Blood (London: Bogle L'Ouverture, 1975).

—.Inglan Is A Bitch (London: Race Today Publications, 1980).

-Mi Revalueshanary Fren: Selected Poems (New York: Ausable, 2006).

—.Tings an Times: Selected Poems (Newcastle upon Tyne: Bloodaxe, 1991).

Joyner, Charles. Down By the Riverside: A South Carolina Slave Community (Urbana: U of Illinois $\mathrm{P}, 1984)$.

Karim, Karim H. The Media of Diaspora Transnationalism (London \& New York: Routledge, 2003).

Kebe, Amy. "Geographies of Displacement: Theorizing Feminism, Migration, and Transnational Feminist Practices in Selected Black Caribbean Writers" (doctoral dissertation, University of Montreal, 2009).

Kincheloe, Joe L., \& Shirley R. Steinberg. "Constructing a pedagogy of whiteness for angry white students," in Dismantling White Privilege: Pedagogy, Politics, and Whiteness, ed. Nelson M. Rodriguez \& Leila E. Villaverde (New York: Peter Lang, 2000): 178-97.

Kubayanda, Josaphat. On Colonial/Imperial Discourse and Contemporary Critical Theory (1992 Lecture Series; College Park: U of Maryland P, 1990).

-The Poet's Africa: Africanness in the Poetry of Nicolás Guillén and Aimé Césaire (Westport CT: Greenwood, 1990).

Kucich, John J. Ghostly Communion: Cross-Cultural Spiritualism in Nineteenth-Century American Literature (Hanover N H: UP of New England, 2004).

Lattas, Andrew. Cultures of Secrecy: Reinventing Race in Bush Kaliai Cargo Cults (New Directions in Anthropological Writing; Madison: U of Wisconsin P, 1998). 
Lawrence, Leota S. "Three West Indian Heroines: An Analysis," College Language Association Journal 21.2 (December 1977): 238-50.

Leach, MacEdward. “Jamaican Duppy Lore," Journal of American Folklore 74/293 (JulySeptember 1961): 207-15.

Leavitt, Ronnie Linda. Disability and Rehabilitation in Rural Jamaica: An Ethnographic Study (Rutherford NJ: Fairleigh Dickinson UP, 1992).

Lemmons, Kasi, dir. Eve's Bayou (Trimark Pictures, US A 1997; 109 min.).

Levine, Lawrence W. Black Culture and Black Consciousness: Afro-American Folk Thought from Slavery to Freedom (Oxford \& New York: Oxford UP, 2007).

Lewin, Olive. Forty Folk Songs of Jamaica (Washington DC: General Secretariat of the Organization of American States, 1973).

—. Rock It Come Over: The Folk Music of Jamaica (Kingston, Jamaica: U of the West Indies $\mathrm{P}, 2000)$.

—. "Traditional Music in Jamaica," Caribbean Quarterly 29.1 (1983):32-43.

Lewis, Shireen K. "The Créolité Movement: Reconfiguring Identity in the Caribbean in the Late Twentieth Century," in Race, Culture, and Identity: Francophone West African and Caribbean Literature and Theory from Négritude to Créolité, ed. Shireen $\mathrm{K}$ Lewis (London: Lexington, 2006): 89-169.

Lippy, Charles. Being Religious, American Style: A History of Popular Religiosity in the United States (Westport CT: Greenwood, 1994).

Lorde, Audre. "An Open Letter to Mary Daly," in This Bridge Called My Back: Writings by Radical Women of Color, ed. Cherríe Moraga \& Gloria Anzaldúa (New York: Kitchen Table, 1981): 94-97.

Lott, Tommy. "'Black Cultural Politics': An Interview with Paul Gilroy,” Found Object 4 (Fall 1994): 56-57.

Lovelace, Earl. "Working Obeah," in Growing in the Dark (Selected Essays), ed. Funso Aiyejina (Trinidad: Lexicon, 2003): 216-26.

Lowney, John. "Haiti and Black Transnationalism: Remapping the Migrant Geography of Home to Harlem," African American Review 34.3 (Autumn 2000): 413-29.

Lull, James. Media, Communication, Culture: A Global Approach (Cambridge: Polity. 1995).

McIsaac, Elizabeth. "Oral Narrative as a Site of Resistance: Indigenous Knowledges, Colonialism, and Western Discourse," in Indigenous Knowledges in Global Contexts: Multiple Readings of Our World, ed. George J. Sefa Dei, Budd L. Hall \& Dorothy Goldin Rosenberg (Toronto: U of Toronto P, 2000): 91-102.

McKay, Claude. Banana Bottom (1933; New York: Harcourt Brace Jovanich, 1961). —. Banjo: A Story Without a Plot (New York: Harcourt Brace Jovanovich, 1932). 
_. Complete Poems, ed. \& annotated by William J. Maxwell (Urbana: U of Illinois P, 2004).

-Constab Ballads (London: Watts, 1912).

- Harlem Shadows (New York: Harcourt, Brace, 1922).

- Home to Harlem (1928; Boston MA: Northeastern UP, 1987).

-. A Long Way from Home (1937; New York: Arno, 1969).

—.My Green Hills of Jamaica (1975; Jamaica \& Trinidad: Heinemann Caribbean, 1979).

. "A Negro Writer to His Critics" (1932), in The Passion of Claude McKay: Selected Poetry and Prose, 1912-1948, ed. Wayne F. Cooper (New York: Schocken, 1973): 132-39.

Mais, Roger. Brother Man (1954; Oxford: Heinemann, 1974).

Mandiela, Ahdri Zhina. Speshal Rikwes (Toronto: Sister Vision, 1985).

Manuel, Peter, with Kenneth Bilby \& Michael Largey. Caribbean Currents: Caribbean Music from Rumba to Reggae (Philadelphia PA: Temple UP, rev. \& expanded ed. 2006).

Marley, Bob. Time Will Tell (New York: Polygram Videos, 1991).

Marshall, Paule. Praisesong for the Widow (New York: G.P. Putnam's Sons, 1983).

—.Reena and Other Stories (New York: Feminist Press, 1993).

Marson, Una. Heights and Depths: Poems (Kingston, Jamaica: The Gleaner, 1931). . "Meet the Colonies" (Reading: West Indies Service, BBC Written Archives, 3 April 1945).

—.The Moth and the Star (Kingston, Jamaica: The Author, 1937).

—. "Nigger," The Keys 1.1 (July 1933): 8-9.

—_. "Pocomania Collection" (MS, Kingston: Institute of Jamaica, 1938).

—.Tropic Reveries (Kingston, Jamaica: The Author, 1930).

Martin, Joanne. More Folk Strings for Solo Violin (Miami F L: Warner Bros, 2003).

Martin, Tony. "Garvey and Scattered Africa," in Global Dimensions of the African Diaspora, ed.Joseph E. Harris (Washington DC: Howard U P, 1983): 243-49.

Mazama, Mambo Ama. "Afrocentricity and African Spirituality," Journal of Black Studies 33.2 (November 2002): 218-34.

Miller, Kei. The Last Warner Woman (London: Weidenfeld \& Nicolson, 2010).

Mitchell, Keith B. "A Still Burning Fire: Afua Cooper's Triptych of Resistance," in Beyond the Canebrakes: Caribbean Women Writers in Canada, ed. Emily Allen Williams (Trenton NJ: Africa World Press, 2008): 37-56.

Moodie, Tony. "Re-Evaluating the idea of Indigenous Knowledge: Implications of AntiDualism in African Philosophy and Theology," paper presented at 'African Renewal, African Renissance': New Perspectives on Africa's Past and Africa's Present (African 
Studies Association of Australia and the Pacific Annual Conference 26-28 November 2004): 1-15.

Moore, Brian L., \& Michele A. Johnson. Neither Led Nor Driven: Contesting British Cultural Imperialism in Jamaica, 1865-1920 (Kingston, Jamaica: U of the West Indies P, 2004): 51-95.

Moore, Gerald. The Chosen Tongue: English Writing in the Tropical World (London: Longmans, Green, 1969).

Mordecai, Martin, \& Pamela Mordecai. Culture and Customs of Jamaica (Westport CT: Greenwood, 2001).

Morris, Mervyn. "In Search of Justice: Linton Kwesi Johnson Interviewed," Jamaica Journal 20.1 (1987): 17-26.

—_. "Introduction" to Louise Bennett, Selected Poems, ed. Morris (Kingston, Jamaica: Sangster's, 1982): iii-xix.

Morrison, Toni. Beloved (New York: Alfred A. Knopf, 1987).

Mphande, Lupenga. "Ideophones and African Verse" (1992), in Tongue and Mother Tongue: African Literature and the Perpetual Quest, Pamela J. Olùbùnmi Smith \& Daniel P. Kunene (Trenton NJ \& Samara, Eritrea: African World Press, 2002): 59-72.

Murdoch, Adlai. Creolizing the Metropole: Migrant Caribbean Identities in Literature and Film (Bloomington: Indiana UP, 2012).

Mutabaruka. Blakk Wi Blak...K...K (Shanachie Records, 1991).

__. "Great Queens of Africa," Jah Lyrics: Reggae Archives, http://www.jah-lyrics.com /index.php?songid=5553 (accessed 16 September 2011).

—.The First Poems 1970-1979 (Kingston, Jamaica: Paul Issa, 1980).

—_. "Nursery Rhyme Lament," Jah Lyrics: Reggae Archives, http://www.jah-lyrics.com /index.php?songid=5585 (accessed 16 September 2011).

Narain, Denise deCaires. "Literary Mothers? Una Marson and Phyllis Shand Allfrey," in Narain, Contemporary Caribbean Women's Poetry: Making Style (New York \& London: Routledge, 2002):1-50.

."The Lure of the Folk: Louise Bennett and the Politics of Creole," in Narain, Contemporary Caribbean Women's Poetry: Making Style (New York \& London: Routledge, 2002):51-88.

Newton, Melanie. "Returns to a Native Land: Indigenity and Decolonization in the Anglophone Caribbean," Small Axe 17.2 (July 2013): 108-22.

Ngugi wa Thiong'o. Decolonising the Mind: The Politics of Language in African Literature (London: James Currey \& Portsmouth NH: Heinemann Educational, 1986).

Nicholls, David. “The Folk as Alternative Modernity: Claude McKay's Banana Bottom and the Romance of Nature," Journal of Modern Literature 23.1 (Fall 1999): 79-94. 
Nichols, Grace. "The Battle with Language," in Caribbean Women Writers: Essays from the First International Conference, ed. Selwyn R. Cudjoe (Wellesley MA: Calaloux, 1990): $283-89$.

—.The Fat Black Woman's Poems (London: Virago, 1984).

-I I i a long memoried woman (London: Karnak House, 1990).

—. "Nanny," in CAFRA Anthology of Caribbean Women's Poetry, ed. Ramabai Espinet (Trinidad \& Tobago: CAFRA, 1990): 269.

Nurse, Donna. What's a Black Critic to Do II: Interviews, Profiles and Reviews of Black Writers (Toronto: Insomniac, 2003).

Nyam, Jopi. Home, Identity, and Mobility in Contemporary Diasporic Fiction (TexTxet 59; Amsterdam \& New York: Rodopi, 2009).

Oakley, Leo. "Ideas of Patriotism and National Dignity" (1970), in The Routledge Reader in Caribbean Literature, ed. Alison Donnell \& Sarah Lawson Welsh (London: Routledge, 1996): 91-93.

Ong, Walter. Orality and Literacy: The Technologizing of the Word (London: Methuen, 1982).

Paris, Arthur. "The Transatlantic Metropolis and the Voices of Caribbean Women," in Caribbean Women Writers: Essays from the First International Conference, ed. Selwyn R. Cudjoe (Wellesley MA: Calaloux, 1990): 82-85.

Pedersen, Carl. "Claude McKay: The True Inventor of Negritude," in Claude McKay: Centennial Studies, ed. A.L. McLeod (New Delhi: Sterling, 1992): 114-22.

Peterson, Charles F. Du Bois, Fanon, Cabral: The Margins of Elite Anti-Colonial Leadership (Lanham MD: Lexington, 2007).

Piot, Charles. "Atlantic Aporias: African and Gilroy's Black Atlantic," South Atlantic Quarterly 100.1 (Winter 2010): 156-70.

Price-Mars, Jean. "Le folk-lore et la littérature," in Price-Mars, Ainsi parla l'oncle: Essais d'ethnographie (New York: Parapsychology Foundation, 1928): 189-99.

Prince, Althea. Being Black: Essays (Toronto: Insomniac, 2001).

Pollard, Charles W. New World Modernisms: T.S. Eliot, Derek Walcott, and Kamau Brathwaite (Charlottesville: UP of Virginia, 2004).

Putnam, Amanda. "Mothering the Motherless: Portrayals of Alternative Mothering Practices within the Caribbean Diaspora," Canadian Woman Studies Journal / Cahiers de la femme canadienne 23.2 (Winter 2004): 118-23.

Quinn, Anthony. "White Teeth by Zadie Smith," New York Times Book Review (30 April 2000): 7-8. [Review.]

Ramazani, Jahan. The Hybrid Muse: Postcolonial Poetry in English (Chicago: U of Chicago $P, 2001)$. 
Ramchand, Kenneth. "Decolonization in West Indian Literature," Transition 22 (1965): 48-49.

Randall, Dudley. "The Black Aesthetic in the Thirties, Forties, and Fifties" (1971), in Modern Black Poets: A Collection of Critical Essays, ed. Donald B. Gibson (Englewood Cliffs NJ: Prentice-Hall, 1973): 34-42.

Reddock, Rhoda. "Feminism, Nationalism and the Early Women's Movement in the English Speaking Caribbean," in Caribbean Women Writers: Essays from the First International Conference, ed. Selwyn R. Cudjoe (Wellesley MA: Calaloux, 1990): 6181.

Reneau, Ingrid. "Dancing the 'Clearing' in African Diaspora Narratives" (doctoral dissertation, Rutgers University, 2000).

Rickford, John R. "Suite for Ebony and Phonics" (1997), in The Language, Ethnicity and Race Reader, ed. Roxy Harris \& Ben Rampton (London: Routledge, 2003): 161-67. Originally published in Discover Magazine 18.12 (December 1997): 82-87.

Riley, Joan. The Unbelonging (1985; London: Women's Press, 2001).

Riofrancos, Maro. "An Interview with Aimé Césaire," in Aimé Césaire: Discourse on Colonialism, ed. Joan Pinkham (New York: Monthly Review Press, 1972): 65-79.

Rodney, Walter. How Europe Underdeveloped Africa (Washington DC: Howard UP, 1982).

Ryan, Judylyn S. Spirituality as Ideology in Black Women's Film and Literature (Charlottesville: UP of Virginia, 2005).

Sander, Reinhard, \& Bernth Lindfors, ed. Ngugi wa Thiong'o Speaks: Interviews with a Kenyan Writer (Oxford: James Currey \& Nairobi: East African Educational, 2006).

Sander, Reinhard, \& Ian Munro, "The Making of a Writer - a Conversation with George Lamming” (1972), in The Routledge Reader in Caribbean Literature, ed. Alison Donnell \& Sarah Lawson Welsh (London: Routledge, 1996): 269-73.

Seaga, Edward. "Revival Cults in Jamaica: Notes Towards a Sociology of Religion," Jamaica Journal 3.2 (1969): 3-13.

Sharpe, Jenny. "Cartographies of Globalisation, Technologies of Gendered Subjectivities: The Dub Poetry of Jean 'Binta' Breeze," Gender \& History 15.3 (November 2003): 440-59.

Sheehan, Sean, \& Angela Black. Jamaica [New York: Benchmark, 2nd ed. 2004).

Sherlock, Philip. "Pocomania" (1943), in Penguin Book of Caribbean Verse in English, ed. Paula Burnett (Harmondsworth: Penguin, 1986): 154-55.

Shroff, Farah M. "Ayurveda: Mother of Indigenous Health Knowledge," in Indigenous Knowledges in Global Contexts: Multiple Readings of Our World, ed. George Dei, Budd L. Hall \& Dorothy Goldin Rosenberg (Toronto: U of Toronto P, 2000): 215-33.

Silvera, Makeda. The Heart Does Not Bend (Toronto: Random House, 2002). 
.An Interview with Ahdri Zhina Mandiela: The True Rhythm of the Language," in The Other Woman: Women of Colour in Contemporary Canadian Literature, ed. Makeda Silvera (Toronto: Sister Vision, 1995): 81-92.

- Silenced: Talks with Working-Class Caribbean Women about their Lives and Struggles as Domestic Workers in Canada (Toronto: Sister Vision, 1983).

- ed. The Other Woman: Women of Colour in Contemporary Canadian Literature (Toronto: Sister Vision, 1995).

Simpson, George Eaton. "Jamaican Revivalist Cults," Social and Economic Studies 5.4 (December 1956): i-iv, 321-442.

—. "Revivalist and Other Cults," in Simpson, Black Religions in the New World (New York: Columbia UP, 1978): 111-17.

Smith, Michael. It A Come: Poems, ed. \& intro. Mervyn Morris (San Francisco: City Lights, 1989).

Smith, Zadie. White Teeth (New York: Random House, 2000).

Smitherman, Geneva. “'The Forms of Things Unknown': Black Modes of Discourse," in Talkin and Testifyin: The Language of Black America, ed. Smitherman (Boston MA: Houghton Mifflin, 1977): 101-66.

Snaith, Anna. "Little Brown Girl' in a 'White, White City': Una Marson and London," Tulsa Studies in Women's Literature 27.1 (2008): 93-114.

St George, Michael. Night Spin (Lethbridge, Alberta: Professional Informatics, 2001).

Swanzy, Henry. "The Literary Situation in the Contemporary Caribbean" (1956), in The Routledge Reader in Caribbean Literature, ed. Alison Donnell \& Sarah Lawson Welsh (London: Routledge, 1996): 249-52.

Taylor, Laurie. "Leggo Relijan: Laurie Taylor Interviews Linton Kwesi Johnson," New Humanist (Spring 2003), http://newhumanist.org.uk/583/leggo-relijan-laurie-taylorinterviews-linton-kwesi-johnson-by-laurie-taylor-spring-2003 (accessed 7 February 2010).

Taylor, Patrick. "Post-Colonial Encounters: Paule Marshall's 'Widow's Praisesong' and George Lamming's 'Daughter's Adventure'," in "And the Birds Began to Sing”: Religion and Literature in Post-Colonial Literatures, ed. Jamie Scott (Cross/Cultures 22; Amsterdam \& Atlanta GA: Rodopi, 1996): 195-207.

Temple, Christel. Literary Pan-Africanism: History, Contexts, and Criticism (Durham NC: Carolina Academic Press, 2005).

_. "Rescuing the Literary in Black Studies," Journal of Black Studies 36.5 (May 2006): 764-85.

Thomas, Bonnie. Breadfruit or Chestnut? Gender Construction in the French Caribbean Novel (Lanham MD: Lexington, 2006).

Thompson, Keith. Life in the Caribbean (Dar es Salaam: New Africa Press, 2010). 
Thompson, Molly. “'Happy Multicultural Land'? The Implications of an 'excess of belonging' in Zadie Smith's White Teeth," in Write Black, Write British: From Post Colonial to Black British Literature, ed. Kadija Sesay (London: Hansib, 2005): 122-40.

Tillery, Tyrone. Claude McKay: A Black Poet's Struggle for Identity (Amherst: U of Massachusetts P, 1992).

Timothy, Roberta. "Resistance Education: African / Black Women Shelter Worker's Perspectives" (doctoral dissertation, University of Toronto, 2007).

Tomlinson, Lisa. Personal interview with Mutaburuka, 15 August 2003.

Urioste-Buschmann, Martina. "The Caribbean Allegory of Mami Wata: A Decolonial Reading of Gendered 'Plantation Memories' Within Contemporary Jamaican Fiction," in Essays: Exploring the Global Caribbean, ed. Susan Roberson (Newcastle upon Tyne: Cambridge Scholars, 2013): 2-19.

Van Vechten, Carl. Nigger Heaven (New York: Alfred A. Knopf, 1926).

Walcott, Derek. Another Life (New York: Farrar, Straus \& Giroux, 1973).

Walcott, Rinaldo. Black Like Who? Writing Black Canada (Toronto: Insomniac, 1997).

Walker, Klive. Dubwise: Reasoning from the Reggae Underground (Toronto: Insomniac, 2005).

Walrond, Eric. "The Hebrews of the Black Race," International Interpreter (14 July 1923): 468-69.

Washington, Robert E. The Ideologies of African American Literature: From the Harlem Renaissance to the Black Nationalist Revolt (Lanham MA: Rowman \& Littlefield, 2001).

Watson, G. Llewellyn. Jamaican Sayings: With Notes on Folklore, Aesthetics, and Social Control (Gainesville: UP of Florida, 1991).

Watts, Linda S. Encyclopedia of American Folklore (New York: Facts on File, 2006).

Welsh, Sarah Lawson. "Experiments in Brokenness: The Creative Use of Creole in David Dabydeen's Slave Song” (1996), in The Routledge Reader in Caribbean Literature, ed. Alison Donnell \& Sarah Lawson Welsh (London: Routledge, 1996): 416-24.

Wieviorka, Michel. "Racism and Diasporas," Thesis Eleven 52.1 (1998): 69-81.

Williams, Emily Allen, ed. Beyond the Canebrakes: Caribbean Women Writers in Canada (Trenton NJ: Africa World Press, 2008).

Williams, Nadine. Culmination of Marriage Between Me and My Pen (Toronto: The author, 2008).

—.A Poetic Journey... Pen On Fyah': Continuing the Journey from the Culmination of Series (Toronto: The author, 2011).

Wilson, Amber.Jamaica: The Culture (Stevens Point WI: Worzalla, 2004). young, d'bi. rivers... and other blackness... between us (Toronto: Women's Press, 2007). Zephaniah, Benjamin. The Dread Affair: Collected Poems (London: Arena, 1985). 
Zimra, Clarisse. "Righting the Calabash: Writing History in the Female Francophone Narrative," in Out of the Kumbla: Caribbean Women and Literature, ed. Carole Boyce Davies \& Elaine Fido Savory (Trenton NJ: Africa World Press, 1990): 143-59. 


\section{— Index -}

"A Merica" (Bennett) 17

Achebe, Chinua 165

"Africa Wailin"' (Afua Cooper) 73, 74, 76, 93, 171

Agard, John 78, 79, 99; “Listen Mr. Oxford Don" 78, 99; Mangoes and Bullets 79 Agarwal, Supriya, \& Jasbir Jain xviii Ahokas, Prjo 180

Alexander, Simon A. James 19, 150

Allen, Lillian viii, xxiv, $67,70,71,72,73$, $75,76,77,78,79,80,83,84,85,86,87$, $88,89,92,93,97,99,103,105,106,107$, $108,109,112,115,116,117,118,119,120,121$, 122, 123, 131, 133, 134, 135, 167, 174; "Birth Poem" 121, 122; "Condition Critical" 87; "Freedom is Azania (South Africa Must Be Free)" 131; "I Am African" 133, 135; "I Fight Back" 70, 108, 118, 120, 167; "Limbo Dancer" 84; "Nellie Belly Swelly" 115; "One Poem Town" 77, 78, 99; "Psychic at Twelve" 79; Revolutionary Tea Party 71; "Riddim and Hardtimes" 79, 92, 93, 122; "Rub a Dub Style Inna Regent Park" 71, 72, 112, 117; "Tribute to Miss Lou" 107; Women Do This Every Day 67, 71, 72, 73, 77, 79, 80, $84,88,103,106,107,108,109,112,116,117$, $118,131,133,134$
Alleyne, Mervyn 3, 19

Altink, Henrice 11

"Ancestral Way" (St George) 93

"And I Remember" (Afua Cooper) 88

Androutsopoulos, Jannis, \& Arno Scholz

75

"Anfinish Revalueshan, Di" (Johnson) 95

Another Life (Walcott) 139

Anthias, Floya xiv

"Apple Woman's Complaint, The"

(McKay) 42, 131-32

Armstrong, Neil 124

Arrivants, The (Brathwaite) 83

Asante, Molefi Kete 142; \& Emeka

Nwadiora 125

Asante, S.K.B. 30

"At the Prison Gate" (Marson) 52

"Atabeya" (Afua Cooper) 129

"Atlantic Drift" (Breeze) 120, 121

"Aunts" (Afua Cooper) 119

Aunty Roachy Seh (Bennett) 16, 19

"Back to Africa" (Bennett) 18

Baker, Houston A., Jr. 79

Banana Bottom (McKay) 32-36, 41, 46, 55, 137,165

Banjo (McKay) 137

Bannerji, Himani 109 
Baraka, Amiri 8, 35, 36, 73, 145

Barrett, Leonard E. 61

Baugh, Edward 27

Beckford, Sharon 153, 154

Beckles, Hilary M. 145

Beckwith, Martha Warren 15, 16, 76

Belafonte, Harry 11

Bell, Bernard W. 147

Beloved (Morrison) xxi, 83, 149

Bennett, Louise 16, 17, 18, 19, 20, 21, 23, 24, $25,39,61,76,92,105,106,107,115,133$, 165, 167, 182; "A Merica" 17; Aunty

Roachy Seh 16, 19; "Back to Africa" 18; "Candy Seller" 23; "Colonization in Reverse" 182; "Duppy Market" 24; "Dutty Tough" 20, 115; "Jamaican Oman" 133; Jamaica Labrish 17, 18, 19, 20, 24, 92, 181; "South Parade Peddler" 23, 92

"bible and gun" (young) 175

"Birth Poem" (Allen) 121, 122

"Black Bwoi" (Williams N) 176

"Black Ooman" (Mandiela) 110, 131

Bluest Eye, The (Morrison) 161

Blyden, Edward Wilmot xvii

"Bobby to the Sneering Lady"(McKay) 41

Boehmer, Elleke 121

Bonnett, Aubrey W. 162

Bounty Killa (dancehall DJ) 40

Brand, Dionne xix

Brathwaite, Edward Kamau 3, 4, 5, 23, 25, $36,39,41,42,43,50,51,61,62,78,83,87$, 102; The Arrivants 83

Braziel, Jana E., \& Anita Mannur xiv Breath, Eyes, Memory (Danticat) 157 Breeze, Jean 'Binta' viii, xxiv, 17, 105, 111, $112,113,114,120,121,124,125,127,128$,
129, 167, 178, 179, 180; "Atlantic Drift" 120, 121; "Dubwise" 124; "I Poet" 178; "Ordinary Mawning” 111, 114; Riddym Ravings 112, 113; Spring Cleaning 120, 128, 129, 178, 179; "Spring Cleaning" 128; "Warner" 127

Brodber, Erna 23, 55, 128, 159; Myal 128 Brother Man (Mais) 65

"Brown Baby Blues" (Marson) 50 Brown Girl in the Ring (Hopkinson) 83

Brown Spencer, Elaine A. 42 Brown, Ethelred, \& Eugene Kinckle Jones 51

Brown, Lloyd 49

Brown-Guillory, Elizabeth xviii

Bucknor, Michael A. xix, xx

Burnett, Michael 8

Burnett, Paula 8

Burning Spear 14

Burton, Richard D.E. 22, 23, 103

Cabral, Amilcar 33, 55, 56, 170

Caesar, Burt 89, 91, 95

Campbell, George 121; "History Makers" 52,121

Campbell, Mark xi

Campbell, W.A., Marguerite: A Story of the Earthquake 32

"Candy Seller" (Bennett) 23

"Cane Field Blues" (Marson) 50

Carr, Brenda 76

Carrera Suárez, Isabel 171

Césaire, Aimé 35, 36, 38, 39, 45, 46, 59, 95

Chamberlain, Mary Ann 172

Chamberlin, Edward 139

Chambers, Douglas B. viii

"Child is Alive, The" (Afua Cooper) 122, 123,126 
Chosen Place, the Timeless People, The (Marshall) 36

Christian, Barbara xxiii

"Christopher Columbus" (Afua Cooper) 88

"Cinema Eyes" (Marson) 49, 62, 107

Clark, VèVè vii, xii, xviii, 16, 52,68, 163

Clarke, George Elliott xvi

Clarke, John Henrik xvii

Cliff, Michelle, No Telephone to Heaven 150

Clifford, James 183

Collier, Gordon 126

Collins, Patricia Hill 118, 119

"Colonization in Reverse" (Bennett) 182

Color Purple, The (Walker) 161

"Condition Critical" (Allen) 87

"Congo Wi Come From" (Afua Cooper) 134, 135

Constab Ballads (McKay) 37, 39, 40, 41, $42,43,46,132$

Cooke, Sam 14

Cooper, Afua xxiv, 17, 25, 71, 75, 80, 81, 82, $85,86,87,88,89,98,101,102,105,107$, $108,109,110,114,119,120,124,125,127$, 128, 134, 151, 164, 168, 170, 171, 174, 176; “Africa Wailin"” 73, 74, 76, 93, 171; “And I Remember" 88; "Atabeya" 129; "Aunts" 119; "The Child is Alive" 122, 123, 126; "Christopher Columbus" 88; "Congo Wi Come From" 134, 135; Copper Woman 73, 74, 75, 76, 83, 87, $114,115,122,123,124,126$, 129, 130, 134, 135, 172; "For Christine and Iselena" 119; Memories Have Tongues 81, 82, 88, 109, 110, 119, 120, 124, 134, 164, 170, 171; "My Father's Mother" 118; "My Piece" 170, 174; "Negro Cemeteries" 113; "Night
Ease" 114; "Oh Canada” 109; "Seven Children" 119; "She Dance" 81, 82, 124; "Stepping To Da Music/Sic" 82; "True Revolution" 86, 97, 134; “The Upper Room" 80, 168

Cooper, Carolyn xxii, 3, 4, 5, 16, 17, 21, 23, $33,53,54,55,62,92,107,126,133,146$, 167

Cooper, Wayne 47,138

Copper Woman (Afua Cooper) 73, 74, 75, $76,83,87,114,115,122,123,124,126,129$, $130,134,135,172$

Cramer, Louise 9, 10

Crawford, Charmaine 120, 121, 157

Crick Crack Monkey (Hodge) 152

Culmination of Marriage Between Me and My Pen (Nadine Williams) 176, 177, 179

Cundall, Frank, \& Izett Anderson 20

Daly, Mary 130

Dance, Daryl Cumber 11

Danticat, Edwidge 152, 157; Breath, Eyes, Memory 157; Krik? Krak! 152

Davis, Andrea xi, xix, 158

Dawes, Kwame xiii, 29, 30, 36, 102, 103

Dei, George J. Sefa vii, viii, xi, xii, xiii, 47, $56,67,68,79,102,161,163$; \& Alireza Asgharzadeh ix

Dillinger (Rastafari DJ), "Natty Dread a the General" 100

Dixon, Melvin 147

Dodds, E., Maroon Medicine 32

Donnell, Alison 31; \& Sarah Lawson

Welsh 39

Douglass, Frederick xvii

Drake, St Clair 86

Dread Affair, The (Zephaniah) 100, 101

"Dread Eyesight" (Zephaniah) 100 
“Dread John Counsel” (Zephaniah) 99, 100

"Dream Deferred, A" (Hughes) 112

Du Bois, W.E.B. 59

Dub Poets Collective 71

Dubey, Madhu 123

"Dubwise" (Breeze) 124

Duncan, Carol B. 4

"Duppy Market" (Bennett) 24

"Dutty Tough" (Bennett) 20, 115

Edwards, Nadi $36,85,86$

Elabor-Idemudia, P. 22

Elephant Man (dancehall artist) 85

Eve's Bayou (dir. Lemmons) 69

Exil selon Julia, L' (Pineau) 159

Fables From the Women's Quarter (Harris) 116

Fals Borda, Orlando xi

Fanon, Frantz xxiii, 31, 32, 65, 67, 85, 169

Farred, Grant 161, 162

Fat Black Woman's Poems, The (Nichols)

$5^{0}$

Ferly, Odile xviii

"Fite dem Back" (Johnson) 89, 90, 108

"For Christine and Iselena" (Afua Cooper) 119

Forbes, Curdella 159

Ford-Smith, Honor 3

"Freedom is Azania (South Africa Must

Be Free)" (Allen) 131

Gadsby, Meredith M. xviii, xix

Garvey, Marcus xv, xvii, 18, 19, 29, 31, 45, $48,132,147$

Gerima, Haile, dir., Sankofa 122
“Gettin' de Spirit" (Marson) 56, 81, 124, $129,15^{8}$

Giddens, Anthony 75

Gikandi, Simon 182

Gilkes, Michael 35

Gilroy, Paul xiv, xxi, 8, 9, 59, 6o, 70, 75, 85, $86,102,143,171$

"God and Armaments" (Marson) 57

Goldblatt, Patricia 181

Goodison, Lorna, "River Mumma" 128

"Gordon to the Oppressed Natives"

(McKay) 43

Goudie, Sean X. 51

Gourdine, Angeletta K.M. xix

"Great Queens of Africa" (Mutabaruka) 66,67

Gross, Jason 101

Guano, Emanuela 127

Guarnizo, Luis Eduardo et al. 162

Guillén, Nicolás 50, 60

Habekost, Christian $\mathrm{xx}, \mathrm{xxi}$

Hall, Stuart x, xiv, 59, 75, 162

"Hard Times" (McKay) 42

"Harlem Dancer" (McKay) 45

Harlem Shadows (McKay) 45

Harris, Claire 171; Fables From the Women's Quarter 116; "Policeman

Cleared in Jaywalking Case" 114

Hathaway, Heather 153

Heart Does Not Bend, The (Silvera) 148, 149, 150, 153, 154, 155, 157, 158, 159, 16o, 161

"Heart of the Constab" (McKay) 92 Heights and Depths (Marson) 14, 48 "History Makers" (Campbell) 52, 121 Ho, Christine G.T., \& Keith Nurse xviii 
Hodge, Merle 38, 152; Crick CrackMonkey $15^{2}$

Hodges, Hugh xxi, xxii, 15, 31, 59, 60

Home to Harlem (McKay) xxiv, 46, 135, 137, 138, 140, 141, 143, 146, 147, 148, 16o, $161,169,172,173$

Hondagneu-Sotelo, Pierrette, \& Ernestine Avila 120

hooks, bell xvii

Hopkinson, Nalo, Brown Girl in the Ring 83

Hughes, Langston, “A Dream Deferred” 112

Hurston, Zora Neale, Moses, Man of the Mountain 21

Hussain, Ahmede 99

Hyatt, Charles, When Me Was a Boy 12

"I Am African" (Allen) 133, 135

"I Fight Back" (Allen) 70, 10 8, 118, 120, 167

I is a long memoried woman (Nichols) 150

"I Poet" (Breeze) 178

"I Shall Return" (McKay) 157

"If I woz a Tap Natch" (Johnson) 94

"IfWe Must Die" (McKay) 45

Igweonu, Kene 84, 85

Immigrants, The (Lamming) 180

"In Jamaica" (Marson) 14

Inglan Is A Bitch (Johnson) 89, 90

"Inglan Is a Bitch" (Johnson) 90, 108

It A Come (Smith, Mikey) 63, 66

Jackson, Mahalia, "In the Upper Room" 80

Jamaica Labrish (Bennett) 17, 18, 19, 20, 24, 92, 181

"Jamaican Oman" (Bennett) 133

James, C.L.R. xvi, 30, 45, 112
James, Winston 39, 40, 43, 46, 64, 65, 131,

155, 157

Jarrett-Macauley, Delia 53, 64

Jekyll, Walter 6, 26, 34, 37, 38

Jenkins, Lee M. 37, 47

Johnson, Albert 79

Johnson, Linton Kwesi viii, xxiv, 71, 89, 90, 91, 92, 93, 94, 95, 96, 97, 98, 101, 102, 103, 108, 156, 166, 167, 169, 175; “Di

Anfinish Revalueshan" 95; "Fite dem

Back" 89, 90, 108; "If I woz a Tap

Natch" 94; Inglan Is A Bitch 89, 90;

"Inglan Is a Bitch" 90, 108; Mi Revalue-

shanary Fren 94; "Problems" 98;

"Reality Poem" 93; "Reggae fi Dada"

97; "Reggae for Radni" 96; "Song of

Blood" 98; "Sonny's Lettah" 91, 92, 102;

Tings an Times 90, 92, 93, 96, 97, 98

Jones, Evan, "Song of the Banana Man” 13,

14

Joseph, Clifton 71

Joyner, Charles 125

Karim, Karim H. 162

Kebe, Amy xix, 160

"Kerosene Lamp" (Williams N) 176-77

Kincheloe, Joe L., \& Shirley R. Steinberg 141

"Kinky Hair Blues" (Marson) 49

Krik? Krak! (Danticat) 152

Kubayanda, Josaphat 35, 38, 56, 62, 95

Kucich, John J. 125

Lamming, George 98, 180; The

Immigrants 180

Last Warner Woman, The (Miller) 128

Lattas, Andrew 27

Lawrence, Leota S. 35 
Leach, MacEdward 24

Leavitt, Ronnie Linda 24

Lemmons, Kasi, dir., Eve's Bayou 69

Levine, Lawrence W. 22, 26

Lewin, Olive $1,6,7,8,9,12,25,26$

Lewis, Shireen K. 39

"Limbo Dancer" (Allen) 84

Lippy, Charles 125

"Listen Mr. Oxford Don" (Agard) 78, 99

Lonely Londoners, The (Selvon) 181

Long Way from Home, A (McKay) 138, 139

Lorde, Audre 130

Lott, Tommy 102

Lovelace, Earl 34

Lowney, John 146

McIsaac, Elizabeth 60

McKay, Claude xxii, xxiii, xxiv, 14, 30, 31, $32,33,34,35,36,37,39,40,41,42,43$, $44,45,46,47,48,51,52,53,54,55,56$, $57,58,59,60,61,62,63,64,65,66,68$, $89,90,92,94,102,131,132,133,135,137$, $138,139,140,141,142,143,144,145,146$, $147,148,151,157,160,161,165,167,169$, 171, 172, 173, 179; “The Apple Woman's Complaint" 42, 131-32; Banana Bottom 32-36, 41, 46, 55, 137, 165; Banjo 137; "Bobby to the Sneering Lady" 41; Constab Ballads 37, 39, 40, 41, 42, 43, 46, 132; "Gordon to the Oppressed Natives" 43; "Hard Times" 42; "Harlem Dancer" 45; Harlem Shadows 45; "Heart of the Constab" 92; "I Shall Return" 157; "If We Must Die" 45; A Long Way from Home 138, 139; "A Midnight Woman to the Bobby" 131; My Green Hills ofJamaica 178; "My Native Land, My Home" 47; "Old
England" 64; "Outcast" 44, 133;

"Quashie to Buccra" 40, 51, 90, 102;

"The Tropics in New York" 46, 58

Mais, Roger, Brother Man 65

Mandiela, Ahdri Zhina viii, 38, 70, 105, 110, 111, 112, 116, 117, 121, 122, 131, 169; "Black Ooman" 110, 131; Oman Git Up 122; "Ooman Git Up" 116, 131; Speshal Rikwes 70, 111, 117, 122 "Mango Time Again" (Marson) 49

Mangoes and Bullets (Agard) 79

Manuel, Peter, with Kenneth Bilby \& Michael Largey 7

Marguerite: A Story of the Earthquake (W.A. Campbell) $3^{2}$

Marley, Bob 2, 8, 14, 25, 66, 74, 82, 112, 131

Maroon Medicine (Dodds) 32

Marshall, Paule xxi, 36, 83, 149, 173, 183; The Chosen Place, the Timeless People 36; Praisesong for the Widow xxi, 83, 149; Reena and Other Stories 172

Marson, Una xxi, xxii, xxiii, 13, 14, 30, 31, $39,48,49,5^{0}, 51,52,53,54,55,56,57$, $58,59,60,61,62,63,64,65,66,68,76$, $81,89,91,98,102,105,106,107,124,129$, $132,158,165,167$; "At the Prison Gate" 52; "Brown Baby Blues" 50; "Cane Field Blues" 50; "Cinema Eyes" 49, 62, 107; "Gettin' de Spirit" 56, 81, 124, 129, 158; "God and Armaments" 57; Heights and Depths 14, 48; "In Jamaica" 14; "Kinky Hair Blues" 49; "Mango Time Again" 49; "Meet the Colonies" 54; The Moth and the Star 48, 49, 50, 51, 52, $53,56,57,58,62$; "Nigger" 64; Pocomania 53, 54, 55, 57, 124; "Pocomania Collection" 53, 54, 57; "Quashie Comes to London" 57, 58, 91; "The Stone 
Breakers 51, 52, 102, 107; "To Hampton" 65; Tropic Reveries 48, 65

Martin, Joanne 11

Martin, Tony $\mathrm{xv}$

Mazama, Mambo Ama 168

"Meet the Colonies" (Marson) 54

Memories Have Tongues (Afua Cooper)

$81,82,88,109,110,119,120,124,134,164$, 170,171

"Mi Cyan Believe It" (Mikey Smith) 71

Mi Revalueshanary Fren (Johnson) 94

Michel, Jean Claude 35

"Midnight Woman to the Bobby, A" (McKay) 131

Miller, Kei, The Last Warner Woman 128

Mitchell, Keith B. 164

Moodie, Tony xiii

Moore, Brian, \& Michele A. Johnson 80

Moore, Gerald 65

Mordecai, Martin \& Pamela 7

Morris, Mervyn 16

Morrison, Toni xxi, 83, 149, 161; Beloved xxi, 83, 149; The Bluest Eye 161

Moses, Man of the Mountain (Hurston) 21

Moth and the Star, The (Marson) 48, 49, $5^{0}, 51,52,53,56,57,58,62$

Mphande, Lupenga 133

Murdoch, Adlai xviii

Mutabaruka 57, 61, 62, 63, 64, 66, 67, 68;

"Great Queens of Africa" 66, 67;

"Nursery Rhyme Lament" 62, 63;

"Retrieve" 57; "Say (for ODUN)" 66

"My Father's Mother" (Afua Cooper) 118

My Green Hills ofJamaica (McKay) 178

"My Native Land, My Home" (McKay) 47

"My Piece" (Afua Cooper) 170, 174

Myal (Brodber) 128
"Nanny" (Nichols) 127

Nanny of the Maroons 131

Narain, Denise deCaires 19

"Natty Dread a the General" (Dillinger) 100

"Negro Cemeteries" (Afua Cooper) 113

"Nellie Belly Swelly" (Allen) 115

Newton, Melanie $\mathrm{x}$

Ngugi wa Thiong'o 38, 99, 167

Nicholls, David 33, 34, 35, 36, 46

Nichols, Grace 50, 126, 127, 150; The Fat Black Woman's Poems 50; I is a long memoried woman 150; "Nanny" 127

"Nigger" (Marson) 64

"Night Ease" (Afua Cooper) 114

Night Spin (St George) 93

No Telephone to Heaven (Cliff) 150

Nurse, Donna 166

"Nursery Rhyme Lament" (Mutabaruka) 62,63

Nyam, Jopi xviii

Oakley, Leo 59

"Oh Canada" (Afua Cooper) 109

"Old England" (McKay) 64

"One Poem Town" (Allen) 77, 78, 99

Ong, Walter 20, 21

"Ooman Git Up" (Mandiela) 116, 122, 131

"Ordinary Mawning" (Breeze) 111, 114

"Outcast" (McKay) 44, 133

Paris, Arthur 70

Pedersen, Carl 142

Philip, Marlene Nourbese xix

Pineau, Gisèle, L'Exil selon Julia 159

Piot, Charles xiv

Pocomania (Marson) 53, 54, 55, 57, 124 
"Pocomania" (Sherlock) 57

"Pocomania Collection" (Marson) 53, 54, 57

Poetic Journey, A (Nadine Williams) 176, 177

"Policeman Cleared in Jaywalking Case" (Harris) 114

Pollard, Charles W. 83

Praisesong for the Widow (Marshall) xxi, 83,149

Price-Mars, Jean 1

Prince, Althea xvi, 112

"Problems" (Johnson) 98

"Psychic at Twelve" (Allen) 79

Putnam, Amanda 152

"Quashie Comes to London" (Marson) 57, 58,91

"Quashie to Buccra" (McKay) 40, 51, 90, 102

Quinn, Anthony 180

Ramazani, Jahan 182

Randall, Dudley 94

"Reality Poem" (Johnson) 93

Reddock, Rhoda 132

Reena and Other Stories (Marshall) 172

"Reggae fi Dada" (Johnson) 97

"Reggae for Radni" (Johnson) 96

Reneau, Ingrid xxi, 83, 84, 140, 144

"Retrieve" (Mutabaruka) 57

Revolutionary Tea Party (Allen) 71

Rickford, John R. 142

"Riddim and Hardtimes" (Allen) 79, 92, 93, 122

Riddym Ravings (Breeze) 112, 113
Riley, Joan viii, xxiv, 136, 137, 148-61, 166, 169, 171, 172, 180; The Unbelonging 14861, 169, 171

Riofrancos, Maro 35

"River Mumma" (Goodison) 128 rivers... and other blackness... between us (young) 174, 175, 176

Rodney, Walter 90, 96, 141, 171

"Rub a Dub Style Inna Regent Park" (Allen) 71, 72, 112, 117

Ryan, Judylyn S. 130

Salkey, Andrew 23

Sankofa (dir. Gerima) 122

"Say (for ODUN)" (Mutabaruka) 66

Schwarz-Bart, Simone 99

Scott, Dennis 23

Seaga, Edward 127

Selvon, Samuel, The Lonely Londoners 181 "Seven Children" (Afua Cooper) 119

Sharpe, Jenny 124

"She Dance" (Afua Cooper) 81, 82, 124

Sheehan, Sean, \& Angela Black 11

Sherlock, Philip, "Pocomania" 57

Shroff, Farah M. vii

Silvera, Makeda viii, xix, xxi, xxiv, 38, 70, $108,135,137,148,149,150,151,153,154$, 155, 156, 157, 158, 159, 16o, 161, 166, 167, 168, 171, 173; The Heart Does Not Bend 148, 149, 150, 153, 154, 155, 157, 158, 159, 160,161

Simpson, George Eaton 127 Smith, Mikey 63,64, 66; It A Come 63, 66; "Mi Cyan Believe It" 71; "Sunday" 66 Smith, Zadie 180, 181, 182; White Teeth 180,181 
Smitherman, Geneva 27

Snaith, Anna 30, 55

"Song of Blood" (Johnson) 98

"Song of the Banana Man" (Jones) 13, 14

"Sonny's Lettah" (Johnson) 91, 92, 102

"South Parade Peddler" (Bennett) 23, 92

Speshal Rikwes (Mandiela) 70, 111, 117, 122

Spring Cleaning (Breeze) 120, 128, 129, 178, 179

"Spring Cleaning" (Breeze) 128

St George, Michael, "Ancestral Way” 93;

Night Spin 93

"Stepping To Da Music/Sic" (Afua

Cooper) 82

"Stone Breakers, The" (Marson) 51, 52, 102, 107

"Sunday" (Smith, Mikey) 66

Swanzy, Henry 59

Taylor, Laurie 95

Taylor, Patrick 183

"tellin the stories yo" (young) 174

Temple, Christel xviii, 7, 54, 73, 76, 77, 85, $86,101,163$

Thompson, Keith 22

Thompson, Molly 180

Tillery, Tyrone 34, 64, 138

Timothy, Roberta xvi, 106

Tings an Times (Johnson) 90, 92, 93, 96, 97, 98

"To Hampton" (Marson) 65

Toussaint Louverture 171

"Tribute to Miss Lou" (Allen) 107

Tropic Reveries (Marson) 48, 65

"Tropics in New York, The" (McKay) 46, $5^{8}$
“True Revolution” (Afua Cooper) 86, 97, 134

Tubman, Harriet 131

Tutuola, Amos 165

Unbelonging, The (Riley) 148-61, 169, 171 "Upper Room, The" (Afua Cooper) 80, 168

Urioste-Buschmann, Martina 128

Van Vechten, Carl 138, 139

Walcott, Derek, Another Life 139

Walcott, Rinaldo 69, 92

Walker, Alice, The Color Purple 161

Walker, Klive 73, 75

Walrond, Eric 50

"Warner" (Breeze) 127

Washington, Robert E. 144

Watson, G. Llewellyn 15

Watts, Linda S. 150

Welsh, Sarah Lawson 13

When Me Was a Boy (Hyatt) 12

White Teeth (Zadie Smith) 180, 181

Wieviorka, Michel xiv, xv

Williams, Nadine 176, 179, 182; "Black

Bwoi" 176; Culmination of Marriage

Between Me and My Pen 176, 177, 178;

"Kerosene Lamp" 176-77; A Poetic

Journey 176, 177

Wilson, Amber 6

Women Do This Every Day (Allen) 67, 71, $72,73,77,79,80,84,88,103,106,107$, $108,109,112,116,117,118,131,133,134$

Wordsworth, William 76

Wright, Michelle xvi 
young, d'bi 170, 174, 175, 176, 182; "bible and gun" $175 ;$ rivers... and other

blackness... between us 174, 175, 176; "tellin the stories yo" 174
Zephaniah, Benjamin viii, xxiv, 71, 89, 98, 99, 100, 101, 164, 166; The Dread Affair 100, 101; "Dread Eyesight" 100; "Dread John Counsel" 99, 100

Zimra, Clarisse 173 